


\section{LIBRARY}

OF THE

UNIVERSITY OF CALIFORNIA.

GIFT OF

Ruthr

Class $308 t$

$-1176$ 



\section{$x^{\circ}$}

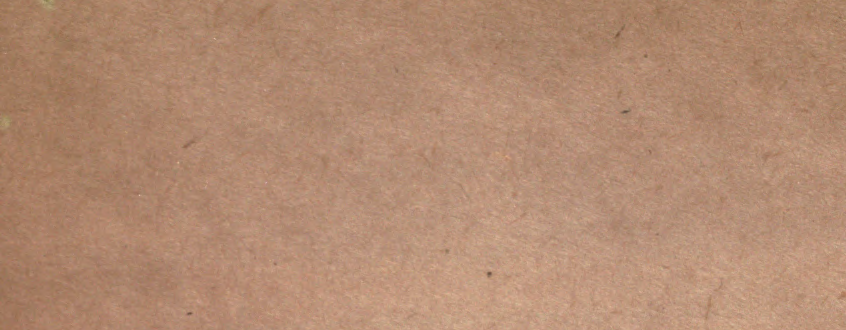
(2)

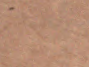

. 




\section{UNIVERSITY OF CALIFORNIA PUBLICATIONS \\ IN \\ BOTANY}

Vol. 3, No. 1, pp. 1-302, Pls, 1-3

December 28,1907

\section{COMPOSITAE OF SOUTHERN CALIFORNIA}

BY

HARVEY MONROE HALL 


\section{UNIVERSITY OF CALIFORNIA PUBLICATIONS}

Note.-The University of California Publications are offered in exchange for the publications of learned societies and institutions, universities and libraries. Complete lists of all the publications of the University will be sent upon request. For sample copies, lists of publications or other information, address the Manager of the University Press, Berkeley, California, U.S.A. All matter sent in exchange should be addressed to The Exchange Department, University Library, Berkeley, California, U.S. A.

BOTANY.-W. A. Setchell, Editor. Price per volume $\$ 3.50$. Volumes I (pp. 418), II (pp. 354), completed. Volume III (in progress).

Vol. 2:-

Cited as Univ. Calif. Publ. Bot.

No. 1. A Review of Californian Polemoniaceae, by Jessie Milliken. Price, $\$ 0.75$

No. 2. Contributions to Cytological Technique, by W.J.V. Osterhout. Price, $\quad .50$

No. 3. Limu, by William Albert Setchell. . . . . . . Price, 25

No. 4. Post-Embryonal Stages of the Laminariaceæ, by William Albert Setchell. . . . . . Price,

No. 5. Regeneration Among Kelps, by William Albert Setchell. Price, $\quad .30$

No. 6. A New Genus of Ascomycetous Fungi, by Nathaniel Lyon Gardner.

No. 7. Teratology in the Flowers of Two Californian Willows, by William

No. 8. The Resistance of Certain Marine Algæ to Changes in Osmotic Pressure and Temperature, by W. J. V. Osterhout.

No. 9. The Rôle of Osmotic Pressure in Marine Plants, by W. J. V. Osterhout.

No. 10. On the Importance of Physiologically Balanced Solutions for cover. Plants, by W. J. V. Osterhout.

No. 11. The Antitoxic Action of Potassium on Magnesium, by W. J. V. Osterhout.

No. 12. Cytological Studies in Cyanophyceae, by Nathaniel Lyon Gardner.

No. 13. On a small Collection of Mosses from Alaska, by J. Cardot and T. Thériot . Price,

No. 14. Some unreported Alaskan Sphagna, together with a summary of the Cryptogamic Work of the University of California Botanical Expedition to Alaska in 1899, by William Albert Setchell. . Price,

No. 15. On Nutrient and Balanced Solutions, by W. J. V. Osterhout. Price,

No. 16. A Synopsis of the North American Godetias, by Willis Linn Jepson.

Vol. 3:-

No. 1. Compositae of Southern California, by Harvey Monroe Hall. Price, 3.00

\section{GRAECO-ROMAN ARCHAEOLOGY. (Large Octavo).}

(Published by the Oxford University Press.)

Vol. 1. The Tebtunis Papyri, Part 1. 1902. Edited by Bernard P. Grenfell, Arthur S. Hunt, and J. Gilbart Smyly. xix +674 pages, with 9 plates. . . Price, $\$ 16.00$

Vol. 2. The Tebtunis Papyri, Part 2. 1907. Edited by Bernard P. Grenfell Arthur S. Hunt, and Edgar J. Goodspeed. $x V+485$ pages, with 2 collotype plates and a map.

Vol. 3. The Tebtunis Papyri, Part 3 (in preparation).

YPTLAII ARCHAEOLOGY. (Quarto).

Vo1. 1. The Hearst Medical Papyrus. Edited by G. A. Reisner.

Hieratic text in 17 facsimile plates in collotype, with introduction and vocabulary. pages 48, 1905. (J. C. Hinrichs, Leipzig, 25 Marks)

. . . . . . . Price, $\$ 8.00$ 


\section{UNIVERSITY OF CALIFORNIA PUBLICATIONS}

\section{COMPOSITAE OF SOUTHERN CALIFORNIA}

A THESIS IN PARTIAL FULFILLMENT OF THE REQUIREMENTS FOR THE DEGREE OF DOCTOR OF PHILOSOPHY IN THE UNIVERSITY OF CALIFORNIA

PRESENTED IN NINETEEN HUNDRED AND SIX BY

HAR̂VEY MONROE HALL

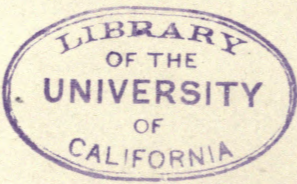

BERKELEY

THE UNIVERSITY PRESS

1908 

UNIVERSITY OF CALIFORNIA PUBLICATIONS

IN

BOTANY

Vol. 3, No. 1, pp. 1-302, Pls. 1-3

December 28, 1907

\section{COMPOSITAE OF SOUTHERN CALIFORNIA*}

BY

HARVEY MONROE HALL

CONTENTS.

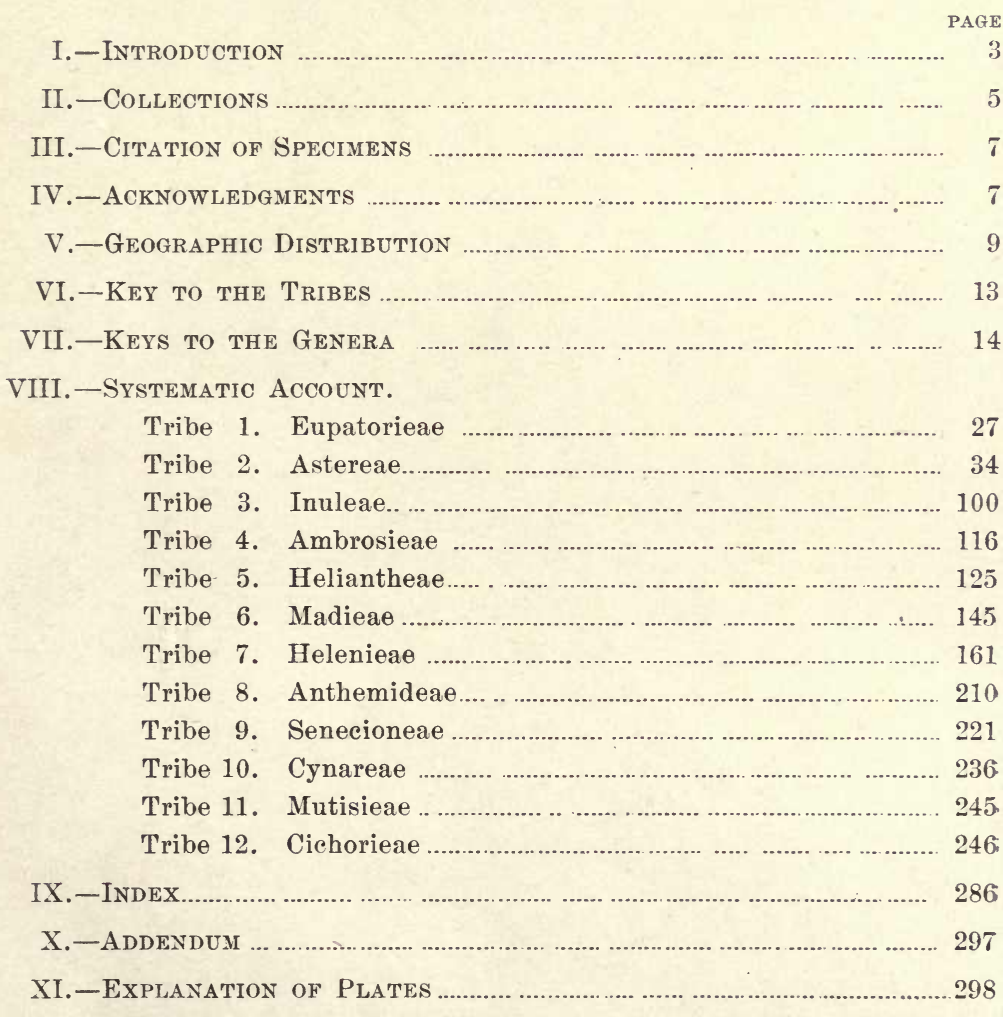

* Citer as Univ. Calif. Publ. Bot. 



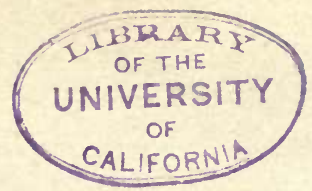

\section{COMPOSITAE OF SOUTHERN CALIFORNIA}

\section{INTRODUCTION.}

The present paper is the result of a systematic study by the author of those Southern California plants belonging to the family of Compositae, and its aim is to present in an intelligible form our present knowledge of this group as it occurs within the area indicated. Only two attempts to classify and describe the Composite flora of Southern California have previously been made, both by Dr. Asa Gray ${ }^{12}$, in connection with works of a much larger scope. These works having been published something over twenty years ago, and much additional knowledge having accumulated during the interval, it seemed advisable that some such revision as the present one aims to be should be undertaken. It is the result not only of over six years of study in the herbarium and field on the part of the author, but also of much careful work carried on by many resident and other botanists who have generously placed their knowledge at his disposal, or published accounts of their studies in the current botanical journals.

By "Southern California" is meant in general that portion of the state lying to the south of Tehachapi Pass, or, more specifically, the counties of Santa Barbara, Ventura, Los Angeles, San Bernardino, Orange, Riverside, San Diego, and Imperial. It lies, roughly speaking, between $32^{\circ} 35^{\prime}$ and $35^{\circ} 50^{\prime}$ north latitude (extending only to $35^{\circ} 5^{\prime}$ in the western part), and between $37^{\circ}$ and $43^{\circ} 40^{\prime}$ longitude west from the meridian of Washington, and includes the islands off the coast as well as the mainland itself. It does not include Lower, or Baja, California, which is a peninsula bordering Southern California on the south and belongs to the Republic of Mexico. It has an area of 116,122 square

\footnotetext{
1 Botany of California, i. 288-443, 613-619 (1876), and ii. 453-460 (1880).

2 Synoptical Flora of North America, i. pt. 2, 48-444 (1884) and 445-455 (1886).
} 
kilometers (44,836 square miles), being nearly the size of the State of Pennsylvania. In altitude, it ranges from 87 meters ( 287 feet) below sea level, in the Lower Sonoran Zone of its Desert Area, to 3500 meters (11,485 feet) in the Alpine Zone of Mt. San Gorgonio (Grayback). It is not necessary to enter more fully into the geographic features nor into a description of the climatic characteristics, since they have been amply treated by Mr. S. B. Parish in his excellent "Sketch of the Flora of Southern California.', 3

The term "Compositae" is here used in its broadest sense, and includes the Cichoriaceae and Ambrosiaceae of some botanists, as well as the Carduaceae, or Compositae proper. The total number of species and varieties recognized in the present paper is 445 , aside from 47 species mentioned as occurring near our borders and to be expected within them. Of this number, about 37 are introduced plants, mostly cosmopolitan or Eastern North American weeds. The 445 species, varieties, and forms actually known to occur in Southern California are distributed by tribes as follows :

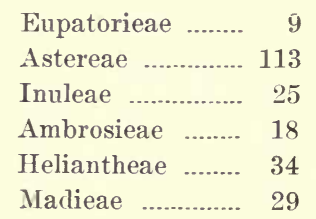

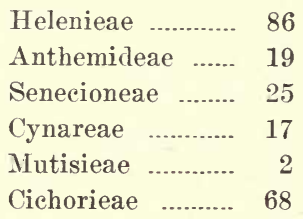

In vusing this list for purposes of comparison it should be noted that the number of species could be greatly augmented by recognizing numerous forms which have been described and given specific names, but which are reduced to synonymy in this paper. While thoroughly in sympathy with every effort to carry systematic botany to the point where all forms are properly recognized and classified, the author is of the opinion that the exaltation of trivial forms, distinguished only by one or two variable characters, to the rank of species is conducive neither to clearness nor to scientific accuracy. A rational system of classification should bring out the natural relationship between the various forms; should, in other words, represent the cleavage

\footnotetext{
${ }^{3}$ Botanical Gazette xxxvi. 203-222 and 259-279 (1903).
} 
of the larger groups into their eomponent parts as it has taken place in nature. Much of our recent work, however, has unfortunately consisted of a mere cutting across the grain, the result being a mass of ehips,--the so-called species,- - each being a purely artificial product and bearing no evident relationship to the others. This is commonly the result of hasty work where the perpetrator has been too busy to work out natural affinities through a comparision of intergrading forms accompanied by field study.

In the matter of generic limits the author has also been rather conservative. Realizing the futility of any effort to establish genera all of which are of equal rank, he has chosen to follow the lines laid down by earlier workers so far as possible rather than to attempt a readjustment, with its inevitable accompaniment of name-changes. Throughout the paper an attempt has been made to follow the International Rules of Nomenclature as laid down by the Vienna Congress of 1905 .

\section{COLLECTIONS.}

Although handicapped by not being able to examine specimens in the older herbaria of Eastern North America and Europe, I have seen the Compositae in practically all the California herbaria, and studied them in the field during a period of abont twelve years. The loan of material from certain of the larger eastern herbaria has also been of considerable assistance.

My work having been prosecuted mainly at the University of California, the Herbarium of that institution has naturally supplied the bulk of the material from which the descriptions are drawn. The collection contains nearly all of the sets recently distributed from Southern California, as well as a nearly complete set of the plants collected on the State Geological Survey, 18601864.

During the spring of 1906 some three weeks were spent at San Diego in working through the Compositae in the Herbarium of Mr. and Mrs. T. S. Brandegee. This herbarium was helpful especially because of the data supplied concerning the distribution of species along our southern and eastern borders and because 
of the large number of type specimens and duplicate types represented. Mr. and Mrs. Brandegee presented their entire collections to the University of California in August, 1906, since which time they have been consulted almost daily in the preparation of this paper.

The California Academy of Sciences Herbarium was consulted at frequent intervals before its nearly complete destruction in the San Francisco fire of April, 1906. The Compositae were here very well represented, and practically all of the Southern California species were examined and notes made. The types of nearly all of Dr. Kellogg's species were preserved here, as well as the types of most of Dr. Greene's early species, and it is very gratifying to learn that many of these types have been saved through the efforts of the curator, Miss Alice Eastwood.

At San Bernardino I had the generous assistance of Mr. S. B. Parish in working through the Compositae of his herbarium, wherein the Southern California flora is so abundantly represented. This botanist was able not only to give much information gleaned from his long studies in that part of the state but also to add, in many cases, the opinions of Dr. Asa Gray, who had examined many of his earlier collections. Dr. A. Davidson, of Los Angeles, likewise offered me the use of his herbarium, where the Compositae were looked over in June, 1904, since which time certain specimens have been loaned for study. It was also in June of 1904 that the herbarium of Mr. George B. Grant, of Pasadena, was visited. It is probable that recent acquisitions to these collections would yield valuable data, but lack of time has prevented a repetition of the visits. The Herbarium of the Leland Stanford Junior University was consulted in February, 1907, with the especial object of examining the types of Southern California Compositae described by Professor Abrams and by Mr. Elmer. Through the kindness of Professor Abrams I was enabled to see all of these types with the exception of one (Machaeranthera Pinosa), which was temporarily unavailable. The J. G. Lemmon Herbarium in Oakland has supplied valuable data concerning certain species discovered by Professor and Mrs. Lemmon when the botanical history of California was still young. 


\section{CITATION OF SPECIMENS.}

In the present paper no attempt has been made to cite all of the specimens examined. If the species under consideration is well known and its distribution clearly given in some standard work, no specimens are cited. When it is rare, when there may be some doubt as to the form described, or when for any reason it may be desirable to know exact stations, all of the specimens at hand are listed. Sometimes a few examples, to fix the identity or to express extreme range, are given and the remainder left without citation. In no case (except possibly by error) has a specimen from Southern California been cited unless it has passed under my personal observation, or a Southern California locality cited unless verified by myself, save in those instances where some other authority, preceded by the expression "acc. to" (according to), is mentioned. The botanists to whom reference is most frequently made in this way and their publications from which the data were gathered are the following:

Asa Gray. Botany of California, Synoptical Flora, and seattered papers mostly in the Proceedings of the American Academy of Sciences.

Sereno Watson. Scattered papers, mostly in the Proceedings of the American Academy of Sciences.

Le Roy Abrams. Flora of Los Angeles and Vicinity, and papers in the Bulletin of the Southern California Academy of Sciences and elsewhere.

S. B. Parish. Manuscript of a paper as yet unpublished,-The Pteridophyta and Spermatophyta of Southern California,-and notes supplied through correspondence.

T. S. Brandegee and Mrs. Katharine Brandegee. Various papers in Zoe, the Bulletin and Proceedings of the California Academy of Sciences, etc., and notes supplied by correspondence or oral communication.

A. Davidson. Catalogue of the Plants of Los Angeles County. (1896).

A. J. McClatchie. Flora of Pasadena.

F. V. Coville. Botany of the Death Valley Expedition, Contributions from the U. S. National Herbarium, vol. iv.

\section{ACKNOWLEDGMENTS.}

It is a pleasure to here make acknowledgment of the generous assistance received from many sources in the prosecution of this work. Professor W. L. Jepson, of the University of California, 
under whose supervision the study has been made, has rendered invaluable aid by his many suggestions and kindly criticism. Professor W. A. Setchell and Mr. Townshend Stith Brandegee, also of the University of California, have rendered much aid in various ways, and Mrs. Katharine Brandegee, because of her intimate knowledge of the California flora and of her generosity in imparting this information, has placed me under lasting obligation. Mr. Samuel B. Parish, of San Bernardino, who has explored the botany of Southern California perhaps more thoroughly than any one else, has not only allowed me the free examination of his collections, but has also permitted the use of his manuscript notes, and even these have been supplemented at frequent intervals through correspondence. This kindness is highly appreciated, since it is not too much to say that no thorough revision of any considerable group of Southern California plants could be prepared at the present time without consulting Mr. Parish and his herbarium.

I am indebted to Miss Alice Eastwood for the privilege of examining specimens in the Herbarium of the California Academy of Sciences, and also her recent collections from Southern California, and likewise to Professor Le Roy Abrams for the privilege of consulting the Herbarium of the Leland Stanford Junior University. Professor J. G. Lemmon, of Oakland; Dr. A. Davidson, of Los Angeles, and Mr. Geo. B. Grant, of Pasadena, have all kindly premitted me to examine their herbaria. Among the resident botanists and collectors who have given much assistance by supplying specimens from their respective localities may be mentioned: Mrs. Charlotte M. Wilder, Professor and Mrs. Joseph Grinnell, Miss Elizabeth Day Palmer, Mr. S. W. Austin, Mr. E. E. Schellenger, Mr. L. A. Greata, Dr. R. J. Smith, Rev. George Robertson, Mr. Fred M. Reed, Mr. E. A. Zumbro, Mr. F. Gilman, and Mr. Ernest Braunton. Mr. Harley P. Chandler, Mr. Ernest B. Babeock and Mr. Harold D. Babcock have accompanied me on various botanical tours, mostly to the north of the district covered by this paper, and rendered valuable aid both in the preparation of material and in its study. My brother, George R. Hall, has made several interesting collections in the higher mountains at my request. 
Sir William Botting Hemsley, of the Royal Botanic Gardens at Kew, England, has kindly supplied notes eoncerning certain Asters and a sketch of the type of Aster Menziesii. Professor B. L. Robinson, of Harvard University, has compared a number of specimens with types at the Gray Herbarium, and supplied valuable material for examination. Dr. J. N. Rose has loaned specimens from the U. S. National Herbarium for comparison. Dr. J. M. Greenman, of the Field Museum of Natural History, has furnished critical notes concerning certain troublesome Senecios. To all of these gentlemen I return my most sincere thanks.

Acknowledgment is also here made of aid received through the Experiment Station of the University of California from the "Adams Fund" of the United States Government. By means of this aid a botanical trip was made through portions of the Mohave Desert and Inyo Co. in May and June of 1906. Although primarily for the purpose of making studies in forage and stockpoisoning plants, concerning which reports will be issued later, much data here utilized was also obtained on the expedition.

\title{
GEOGRAPHIC DISTRIBUTION.
}

It has been found that in discussing the distribution of plants or animals over any considerable area it is conducive to clearness to have that area mapped into life zones, these being essentially thermal belts recognized by the plant growth and animals which they sustain. The following life zones are recognized in Southern California :

\author{
Alpine, or Arctic-Alpine Zone. \\ Hudsonian Zone. \\ Canadian Zone. \\ Transition Zone. \\ Upper Sonoran Zone. \\ Lower Sonoran Zone.
}

The Arctic-Alpine Zone is sharply marked and consists only of the Alpine flora above timber line. The only Compositae of our district restricted to this zone are:

Erigeron compositus discoideus Antennaria media.

Raillardella argentea. 
The Hudsonian and Canadian zones cannot be clearly distinguished from each other in Southern California, but together they occupy the rather narrow belt between timber line and the extensive forests of Yellow Pine (Pinus ponderosa, including its variety Jeffreyi) and White Fir (Abies concolor). Their most characteristic trees with us are the Limber Pine $(P$. flexilis) and the Murray Pine (P. Murrayana), the latter frequently occupying boreal islands completely surrounded by Transition Zone elements. Perhaps none of our Compositae are restricted absolutely to these zones.

The Transition Zone is best marked by the presence of Yellow Pine and White Fir. It is sometimes convenient to speak of a Lower Transition, where the pine is dominant, and of an Upper Transition, where the fir is dominant. Many Compositae are restricted in their distribution to this zone, the list including the following:

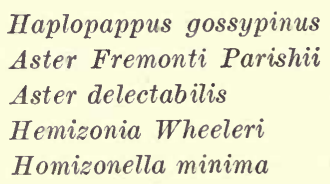

Eriophyllum lanatum obovatum Helenium Bigelovii Arnica Bernardina Crepis acuminata Hieraceum albiflorum

The Upper Sonoran Zone is essentially co-limital with the chaparral belt, but also includes the Piñon belt of the desert ranges, Mt. Pinos, etc. It occupies nearly all of the Cismontane Area, that is, the area west and south of the San Gabriel, San Bernardino, San Jacinto, and Cuyamaca Mts. Common elements indicative of this zone are Chamiso (Adenostoma fasciculatum), Wild Buckwheat (Eriogonum fasciculatum), Beard-tongue (Pentstemon antirrhinoides), Deer-weed (Lotus glaber), etc. Of the Compositae restricted to this zone may be mentioned:

\author{
Ericameria ericoides \\ Ericameria pinifolia \\ Baccharis pilularis \\ Encelia Californica \\ Eriophyllum Nevinii
}

\begin{abstract}
Artemisia Californica Carduus occidentalis Perezia microcephala Malacothrix saxatilis Hieraceum Parishii
\end{abstract}

The Lower Sonoran Zone occupies the Desert Area with the exception of those ranges which extend into the Upper Sonoran. Certain warm areas west of the mountains are perhaps also best classified as Lower rather than Upper Sonoran, noticeably a 
portion of the San Bernardino Plains, where are found desert immigrants that have undoubtedly come by way of Cajon Pass; and portions of southwestern San Diego Co., where desert species have established themselves, coming either through low passes from the Colorado Desert or northward from Lower California. The plants of this zone are nearly all xerophytes with various adaptations to their arid habitat. The following common Compositae are characteristic of this zone:

Brickellia atractyloides
Acamptopappus sphaerocephalus
Ericameria monactis
Chrysothamnus paniculatus
Chrysothamnus nauseosus graveolens
Monoptilon bellioides
Aster Mohavensis
Aster spinosus
Baccharis sergiloides
Franseria dumosa

\author{
Baileya pauciradiata \\ Chaenactis carphoclinia \\ Porophyllum gracile \\ Dysodia Cooperi \\ Pectis papposa \\ Artemisia spinescens \\ Peucephyllum Schottii \\ Lepidospartum squamatum \\ Tetradymia spinosa \\ Malacothrix glabrata
}

Life areas differ from life zones in that they indicate all of the factors influencing the distribution of life, rather than only that of temperature. Three life areas may be distinguished in Southern California, namely, the Desert Area, the Nevadan or Montane Area, and the Cismontane Area, the last including everything southwest of the principal mountain chain. These areas may be subdivided into subareas, for example, the Mohave and Colorado subareas, the Coastal Subarea, etc.

Various papers dealing with plant and animal distribution in Southern California have been consulted in reference to this subject, and especially the works of Dr. C. Hart Merriam, of the Biological Survey, U. S. Department of Agriculture, who was the first to distinguish and name the Life Zones of North America according to our present system. Such papers are:

C. Hart Merriam: Life Zones and Crop Zones of the United States, U. S. Dept. Agr., Div. of Biological Survey, Bull. ix (1898).

C. Hart Merriam: Results of a Biological Survey of the San Franciseco Mountain Region and Desert of the Little Colorado, Arizona, N. A. Fauna No. 3 (1890).

C. Hart Merriam: Results of a Biological Survey of Mt. Shasta, California, N. A. Fauna No. 16 (1899), ete.

S. B. PARISH: A Sketch of the Flora of Southern California, Bot. Gaz. xxxvi. 203-222 and 259-279 (1903). 
Joseph Grinnell: Check-list of California Birds, Pacif. Coast Avifauna No. 3 (1902).

H. M. Hall: A Botanical Survey of San Jacinto Mountain, Univ. Calif. Pub. Botany, i. 1-140 (1902).

H. M. HALL: Some contributions to the Phytogeography of Southern California, Bull. So. Calif. Acad. iii. 19-22 (1904).

F. Stephens: Life Areas of California, Trans. S. Diego Acad. i. 1-8 (1905).

F. V. Coville and D. T. MacDougal: Desert Botanical Laboratory of the Carnegie Institution (1903).

J. BurtT DAvy: The Native Vegetation and Crops of the Colorado Delta, Calif. Agr. Exp. Sta. Bull. No. 140, suppl. (1902).

The following papers, although not dealing directly with distribution in Southern California, have also been helpful:

W. L. Bray: The Ecological Relations of the Vegetation of Western Texas, Bot. Gaz. xxxii. 99-123, 195-217, and 262-291 (1901).

Vernon Batley: Biological Survey of Texas, N. A. Fauna No. 25 (1905).

P. B. Kennedy: Botanical Features around Reno, Muhlenbergia iii. 17-32 (1907).

C. V. PIPER: Flora of the State of Washington, Contr. U. S. Nat. Herb. xi. (1906).

\section{COMPOSITAE. SUNFLOWER FAMILY.}

Herbs, shrubs, or sometimes trees. Flowers in heads (or rarely in spikes or umbels in certain non-Californian genera), borne on the enlarged summit of the common peduncle (receptacle) and surrounded by a common involucre of few to many bracts. Heads usually many-flowered, yet sometimes fewflowered, or even only 1-flowered. Receptacle with or without bracts, these commonly paleaceous or setiform when present and each subtending a flower; the receptacle said to be naked when bearing only flowers within the involucre, chaffy, paleaceous, or bristly when bearing bracts among the flowers. Corollas tubular and 5-toothed or 5-lobed (rarely 4 or 3-merous), or the limb ligulate (strap-shaped) and toothed at apex. When both kinds are present, the flowers with the ligulate corollas occupy the margin of the head and are called ray-flowers; the flowers with the tubular corollas occupy the center and are called disk-flowers; 
such heads are said to be radiate. Heads without ligulate corollas are said to be discoid. The term ray is sometimes used for ray-corolla, sometimes for only the ligule of the ray-corolla. Ray-flowers commonly pistillate, sometimes perfect or neutral: disk-flowers commonly perfect, often staminate or pistillate. Heads homogamous, that is, with all their flowers alike; or heterogamous, that is, with more than one sort of flowers. Homogamous heads may have all the corollas ligulate, or they may be discoid. Calyx-tube united with the ovary, the limb when present called a pappus and greatly varied in structure, consisting of awns, hairs, bristles, scales, or paleae, or in some cases appearing as a mere crown or ring or wholly obsolete. Stamens 5 (rarely 4 or 3 ) inserted on the corolla-tube and alternating with its lobes or teeth; anthers 2-celled, united and forming a tube, or nearly or quite free in Ambrosieae, introrse, from obtuse to auriculate or caudate (tailed) at base, usually appendaged above, this appendage being a prolongation of the connective between the anther-ceils. Style divided above into 2 branches which bear stigmatic lines on their inner face. Ovary 1-celled, 1-ovuled, maturing into an achene, crowned by the pappus when that is present.

\section{KEY TO THE TRIBES.}

\section{A.-Corollas all regular (the heads then discoid) or only the marginal ones ligulate (the heads then radiate).}

Anthers not caudate at the base.

Receptacle naked (without bristles or chaffy bracts, except nos. 83 and 84 ); leaves alternate (except in nos. 3, 59, 64, 65, 82, and 91).

Style-branches thickened upward, obtuse; stigmatic lines not extending beyond the middle: flowers never yellow: rays none...

1. EUPATORIEAE, p. 14.

Style-branches not thickened upward; stigmatic lines in perfect flowers extending to the summit.

Bracts of the involucre usually imbricated: disk-flowers commonly yellow; rays of the same or different color or none: style-branches in perfect flowers flattened and with a distiret (but sometimes very short) terminal appendage.

2. ASTEREAE, p. 15

Bracts of the involucre in few series, seldom much imbricated: disk yellow; rays often of the same color when present: style-branches in perfect flowers with truncate or variously appendaged tips 
Bracts of the involucre imbricated, dry and scarious: flowers white, yellow, or greenish, rays present or absent: stylebranches mostly truncate: pappus none or reduced to a mere erown or ring 8. ANTHEMIDEAE, p. 23.

Bracts of the involucre in 1 or 2 series, little or not at all imbricated, nor scarious: both disk and ray yellow: stylebranches in perfect flowers truncate: pappus of soft capillary bristles (coarse in no. 93)....9. SENECIONEAE, p. 24.

Receptacle with chaffy bracts.

Heads unisexual (except nos. 35 and 36): anthers nearly or quite distinct: rays none: corolla of perfect flowers much reduced or wanting: pappus none or a mere vestige: leaves mostly alternate 4. AMBROSIEAE, p. 18.

Heads not unisexual: anthers united.

Involucre of 1 to several series of bracts, none enfolding rayachenes: reeptacle very chaffy: rays present or wanting: leares mostly opposite or basal.

.5. HELIANTHEAE, p. 19.

Involucre of 1 series of equal bracts, each embracing or enfolding a ray-achene: bracts of the receptacle often in a single series between ray and disk: rays always present (sometimes inconspicuous): leaves alternate or opposite.

6. MADIEAE, p. 20.

Anthers caudate at the base, unappendaged at the tip: heads small: rays none

3. INULEAE, p. 17 .

Anthers long-caudate at the base, with elongated appendages at the tip: receptacle bristly: rays none: leaves alternate: spiny thistles or thistle-like plants 10. CYNAREAE, p. 24.

B.-Corollas all bilabiate and the flowers all perfect

11. MUTISIEAE, p. 25.

C.-Corollas all ligulate and the fiowers all perfect: anthers not caudate: herbage with milky juice: leaves alternate or basal

12. CICHORIEAE, p. 25.

\section{Tribe 1. eupatorieaE. Eupatory Tribe.}

Herbs and shrubs with opposite or alternate mostly undivided leaves. Receptacle flat or somewhat convex, rarely spherical, usually naked. Heads always discoid and the flowers hermaphrodite-fertile. Corolla regular, purple reddish bluish or white, never pure yellow. Anthers not tailed at base. Style-branches semi-cylindric, elongated, more or less clavate or thickened upward, obtuse, stigmatic lines only near the base and inconspicuous. 
Achenes 5-angled or -ribbed.

Pappus-bristles 10 to 12

1. HOFMEISTERIA, p. 27 .

Pappus-bristles only 3 2. MALPERIA, p. 28.

Achenes 10-nerved 3. BRICKELLIA, p. 28.

\section{Tribe 2. ASTEREAE. Aster Tribe.}

Ours all herbs or shrubs with alternate leaves and scentless herbage (but sometimes resinous or gummy). Bracts of the involucre commonly well imbricated (nearly equal in Erigeron and Conyza). Receptacle naked in our genera. Disk-flówers mostly yellow, perfect in all ours save Baccharis. Rays present or absent. Anthers obtuse at base. Style-branches of perfect flowers flattened, conspicuously margined by the stigmatic lines, tipped with a hispid or papillose appendage (this sometimes quite obsolete). Pappus mostly of awns or bristles (truly paleaceous among our genera only in Gutierrezia and Amphiachyris).

A.-Rays present, yellow. (B on p. 16.)

Pappus of several short scales: heads very small: perennials

4. GUTIERREZIA, p. 34 .

Pappus of 2 to 8 eaducous bristles or awns: heads large: perennial herbs 6. GRINDELIA, p. 37 .

Pappus of persistent bristles or awns.

Stems herbaceous throughout (annual and perennial herbs).

Ray-achenes without pappus

9. HETEROTHECA, p. 41.

Ray-achenes with pappus.

Pappus-bristles 3 to 8 : annual

7. PENTACHAETA, p. 39.

Pappus-bristles more numerous (perennials, except 2 species of no. 13).

Herbage villous or hirsute: pappus-bristles. equal or with a very short outer series 10. CHRYSOPSIS, p. 43.

Herbage never villous or hirsute (glabrous to canescent or tomentose).

Bristles of the pappus equal (involucre 4 to $6 \mathrm{~mm}$. high; bracts obtuse or merely acute)......11. SOLIDAGO, p. 45.

Bristles of the pappus unequal (involuere 6 to $12 \mathrm{~mm}$. high; bracts acuminate to subulate or spinose-tipped)

13. HAPLOPAPPUS, p. 49.

Stems suff rutescent, at least below (perennial shrubs).

Heads solitary, terminating nearly naked peduncles: pappus permanently clear white.

Involueral bracts acute: pappus-bristles all slender 
Involueral bracts obtuse: some pappus-bristles flattened Acamptopappus Shockleyi, p. 41.

Heads not solitary (except one stage of Ericameria pinifolia): pappus dull white to reddish.

Pappus-bristles not over 20, flattened

5. AMPHIACHYRIS, p. 36.

Pappus-bristles more numerous, slender.

Involuere hemispheric: leaves spinulose-toothed

Haplopappus junceus, p. 50.

Involucre campanulate, tomentose: leaves entire or serrate ......

Hazardia cana, p. 65.

Involucre narrower: leaves entire........14. ERICAMERIA, p. 51.

B.-Rays present, not yellow. (C on p. 16.)

Pappus of the ray much reduced, seanty or wanting.

Perennial: herbage tomentose, at least when young

19. CORETHROGYNE, p. 69.

Annuals: herbage not tomentose.

Leaves pinnatifid or incised: disk-pappus copious

20. PSILACTIS, p. 73.

Leaves entire: pappus-bristle solitary, plumose at tip

21. MONOPTILON, p. 74.

Pappus well developed in both ray and disk.

Heads sessile, solitary: low desert annual with white or pinkish rays

21. MONOPTILON, p. 74.

Heads variously clustered, or solitary and evidently peduncled.

Style-appendages lanceolate to subulate, acute: involucral bracts in two or more series, unequal 22. ASTER, p. 76.

Style-appendages ovate or oblong, obtuse: involucral bracts imbricated in several series, unequal (low perennial with leaves less than $12 \mathrm{~mm}$. long) 23. LEUCELENE, p. 86.

Style-appendages triangular or oblong, obtuse: involucral bracts in one or two series, mostly equal 24. ERIGERON, p. 87.

\section{C.-Rays none.}

Stems suff rutescent, at least below (perennial shrubs or shrubby plants).

Flowers yellow, perfect.

Pappus-bristles numerous, all slender.

Bracts of the involucre without distinct green tips: leaves entire.

Involucre turbinate or broader: bracts not in distinct vertical ranks: herbage minutely if at all pubescent (usually resinous-punctate) …...............14. ERICAMERIA, p. 51.

Involuere narrower: bracts in more or less distinct vertical ranks: herbage glabrous to tomentose (resinous-punctate only in first two species) 
Bracts of the involucre with distinct green tips.

Leaves terete, resinous-punctate

Chrysothamnus teretifolius, p. 57.

Leaves plane, not punctate.

Flowers permanently yellow: inflorescence terminally cymose 16. ISOCOMA, p. 62.

Flowers yellow changing to brown: inflorescence paniculate 17. HAZARDIA, p. 64.

Pappus-bristles (not over 40) rigid, some with distinetly flattened tips 8. ACAMPTOPAPPUS, p. 41.

Flowers whitish: dioecious plants 26. BACCHARIS, p. 95.

Stems herbaceous throughout (annuals and low herbaceous perennials).

Outer corollas enlarged, more deeply cleft on inner side

18. LESSINGIA, p. 66.

Outer corollas not enlarged, very slender and only one-half as long as style 25. CONYZA, p. 94.

Outer corollas not enlarged, moderately or not at all exceeded by the style.

Involucral bracts searcely imbricated, nearly equal

.24. ERIGERON, p. 87.

Involueral bracts regularly imbricated, unequal.

Flowers yellow, perfect.

Bracts of the involucre all erect

Chrysopsis Wrightii, p. 44.

Outer bracts of the involucre with recurved tips

Aster canescens, p. 85.

Flowers whitish: dioecious perennials 26. BACCHARIS, p. 95.

Tribe 3. inUleae. Everlasting Tribe.

Herbs, shrubs, or rarely trees, with mostly white-woolly or glandular herbage. Leaves alternate (opposite in Psilocarphus), entire, or more or less dentate in one species of Pluchea (even laciniate in some non-Californian species and genera). Heads rather small and discoid in all our species, homogamous or heterogamous, dioecious in some genera. Bracts of the involucre commonly white or scarious. Anthers, with very few exceptions, caudate at base, the tails free or united in pairs. Style-branches of various forms but mostly obtuse or truncate, with marginal stigmatic lines on the inner surface, not appendaged. Pappus, in all of our species, capillary or none. 


\section{A. - Receptacle chaffy: involucral bracts several or none.}

Fertile pistillate flowers all destitute of pappus.

Corolla and style borne laterally upon the fertile achene which, with its enfolding bract, is gibbous 28. MICROPUS, p. 102.

Corolla and style apical: achene straight or only slightly curved.

Fruit-bearing bracts each enclosing its achene and falling away with it.

Leaves alternate: receptacle slender or columnar

29. STYLOCLINE, p. 102.

Leaves opposite: receptacle globose....30. PSILOCARPHUS, p. 104.

Fruit-bearing bracts open, merely subtending the achenes, persistent 31. EVAX, p. 106.

Fetile pistillate flowers of two sorts; the outer destitute of pappus and enclosed each by its bract; the inner with abundant pappus, not enfolded by bracts 32. FILAGC p. 107.

B.-Receptacle naked: involucral bracts numerous.

Herbaceous, or only the base woody.

Herbage densely woolly.

Flowers dioecious: low perennials of high altitudes

33. ANTENNARIA, p. 108.

Flowers all fertile but of two sorts, perfect and pistillate, these borne in the same head. 34. GNAPHALIUM, p. 111.

Herbage merely glandular-puberulent. 27. PLUCHEA, p. 100.

Shrub with willow-like stems, 2 to $5 \mathrm{~m}$. high (except when depauperate): herbage silvery with appressed hairs. 27. PLUCHEA, p. 100.

\section{Tribe 4. ambrosieaE. Ragweed Tribe.}

Coarse homely weeds with small greenish or white discoid heads. Leaves alternate or the lowest sometimes opposite. Flowers unisexual, the staminate and the pistillate either in the same head (the heterogamous heads then solitary in the axils) or in separate heads (the staminate then in a raceme or cluster above the pistillate, which are few and axillary). Receptacle of the staminate or of the perfect heads with chaff-like bracts. Corolla of pistillate flowers none or a mere rudiment. Anthers distinct or scarcely coherent, not caudate. Pappus either none or reduced to a mere vestige. Fruit commonly a bur.

Heads containing both staminate and pistillate flowers, the latter at the margin.

Achenes neither bordered nor winged.

Leaves entire or nearly so: achenes glabrous 35. IVA, p. 116. 
All but uppermost leaves pinnately parted: achenes villous.

36. OXYTENIA, p. 117

Achenes with a searious pectinate border or wing....37. DICỎRIA, p. 117. Heads unisexual, staminate and pistillate heads on the same plant; involucre of pistillate heads closed, only the style-branches exserted; staminate heads with open involucres.

Involucre of pistillate heads with broad silvery-scarious wings.

38. HYMENOCLEA, p. 118.

Involucre of pistillate heads bur-like.

Staminate heads with united involucral bracts.

Pistillate involucre beaked at apex and armed near the beak with a single row of short prickles. 39. AMBROSIA, p. 119.

Pistillate involucre with 1 to 4 beaks and armed with several rows of prickles. 40. FRANSERIA, p. 120.

Staminate heads with distinct involucral bracts.

41. XANTHIUM, p. 123.

\section{Tribe 5. HeliantheaE. SUnflower Tribe.}

Herbs or shrubs with mostly yellow flowers, many with balsamic-resinous juice. Heads homogamous and discoid or heterogamous with pistillate or neutral ray-flowers and hermaphrodite disk-flowers, the latter either fertile or sterile. Receptacle with chaff-like bracts, each subtending a flower. Anthers obtuse at base, not caudate. Pappus various or wanting but never of simple truly capillary bristles. Achenes thick or flattened contrary to the subtending chaffy bract, never parallel with it.

A.-Involucre either imbricated or its outer bracts foliaceous and exceeding the inner ones.

Disk-achenes thick, 4 or 5-angled when mature.

Rays small and white or wanting.

Pappus of 15 to 20 plumose bristles: heads discoid

42. BEBBIA, p. 125.

Pappus paleaceous: rays white. 43. GALINSOGA, p. 126.

Pappus of barbed awns: rays white or none........51. BIDENS, p. 143. Rays conspicuous, yellow.

Pappus none.

Leaves scattered, narrow ( $1 \mathrm{~cm}$. or less broad)

GYMNOLOMIA, p. 145.

Leaves mainly basal, ample (8 to $15 \mathrm{~cm}$. broad)

44. BALSAMORHIZA, p. 126. 
Pappus present.

Ray-flowers maturing achenes: pappus coroniform: leaves ample 45. WYETHIA, p. 127.

Ray-flowers not maturing achenes.

Pappus of 2 slender awns thickened at base and 4 or more much shorter erose paleae: peduncles slender.

46. VIGUIERA, p. 128.

Pappus of 2 acute or awned paleae: peduncles often swollen under the head

47. HELIANTHUS, p. 129.

Disk-achenes flat, compressed, the 2 acute angles either ciliate or winged.

Achenes not winged, but strongly ciliate. 48. ENCELIA, p. 133.

Achenes broadly winged 49. VERBESINA, p. 137.

Disk-achenes sterile: ray achenes completely enclosed in their bracts. 52. MELAMPODIUM, p. 144.

B.-Involucral bracts in two very dissimilar series and the outer ones much narrower than the inner ones.

Leaves mainly radical or alternate, linear to filiform or parted into very narrow lobes 50. COREOPSIS, p. 139.

Leaves opposite.

Pappus of barbed awns: heads medium-sized or large.

51. BIDENS, p. 143.

Pappus paleaceous: heads small: rays white......43. GALINSOGA, p. 126.

Pappus none: marginal achenes completely enclosed in their bracts 52. MELAMPODIUM, p. 144.

Tribe 6. MADIEAE. Tarweed Tribe.

Ours annual or biennial herbs (except one species of no 55). Herbage often glandular and viscid or heavy-scented. Leaves alternate or opposite. Bracts of the involucre in a single series, each partly or completely enclosing an achene. Bracts of the receptacle commonly in a single series between disk and ray and often united into a cup, or sometimes scattered among the diskflowers. Rays always present in our genera, sometimes inconspicuous. Anthers not caudate. Ray-achenes always fertile, seldom pappose ; disk-achenes either fertile or sterile, their pappus. paleaceous, awn-like, or none.

Ray-achenes laterally compressed with narrow back, each completely enfolded by its deeply sulcate involucral bract which is strongly carinate on the back. 53. MADIA, p. 145 .

Ray-achenes commonly obcompressed with broad rounded back, each partially or wholly enfolded by its involucral bract which is also rounded on the back. 
Involucral bracts conduplicately folded for their whole length and each completely enclosing its achene.

54. HEMIZONELLA, p. 147.

Involucral bracts with only the lower partion conduplicately folded, the upper portion being flat.

Ray-achenes only half-enclosed by the infolded margins of the involucral bracts 55. HEMIZONIA, p. 148.

Ray-achenes wholly enclosed by the infolded margins of the involucral bracts, these meeting over the face of the achene.

-Disk-achenes without pappus: heads clustered

56. LAGOPHYLLA, p. 155.

Disk-achenes usually with distinct pappus: heads large, solitary.

Pappus of 5 to 20 slender awns

.57. LAYIA, p. 156.

Pappus of about 10 broad paleae in 2 series

58. ACHYRACHAENA, p. 160.

\section{Tribe 7. HELENIEAE. Sneezeweed Tribe.}

Herbs, or a few species suffruticose. Leaves alternate or opposite, in one subtribe punctate with oil-glands. Heads radiate or discoid. Involucral bracts mostly in only one to three series, herbaceous or in a few genera with membranous margins. Receptacle not paleaceous, yet sometimes bristly or hairy. Anthers not caudate. Pappus of paleae, awns, or bristles, or often wanting.

\section{A.-Leaves all opposite: rays present, yellow.}

Bracts of the involucre unequal, broad: pappus none: succulent perennial 59. JAUMEA, p. 161.

Bracts of the involucre equal.

Involucre cup-like, its bracts united 64. LASTHENIA, p. 167.

Involuere of distinct bracts.

Herbage destitute of oil-glands: involucral bracts ovate or oblong......... 65. BAERIA, p. 168.

Herbage dotted with oil-glands: involucral bracts linear

82. PECTIS, p. 209.

\section{B.-Leaves alternate, at least above.}

Pappus present.

Heads discoid, or the rays if present very inconspicuous.

Leaves entire, at least the upper.

Flowers yellow.

Herbage gummy: pappus of 8 to 12 obtuse paleae 
Herbage not gummy: pappus-paleae 5 or fewer, subulateawned. 72. RIGIOPAPPUS, p. 187.

Flowers not yellow.

Herbage rough-pubescent: pappus of 4 to 8 paleae.

69. PALAFOXIA, p. 179.

Herbage glabrous: pappus of copious capillary bristles.

81. POROPHYLLUM, p. 209.

Leaves from dentate to pinnatifid or pinnately parted.

Herbage glabrous but dotted with oil-glands.

80. DYSODIA, p. 208.

Herbage pubescent (mostly tomentose), at least when young: no oil-glands.

Involucral bracts with colored hyaline margins.

68. HYMENOPAPPUS, p. 177.

Involucral bracts herbaceous.

Pappus of several paleae (fimbriate in one species).

Stems $5 \mathrm{~cm}$. or less high: involuere $3 \mathrm{~mm}$. high

Eriophyllum Pringlei, p. 181.

Stems taller: involucre larger.

73. CHAENACTIS, p. 188.

Pappus apparently of slender tawny bristles: low desert annual......................... T5. TRICHOPTILIUM, p. 202.

Heads radiate.

Rays white or purplish, never yellow.

Pappus an obscure crown and often 1 or 2 awns: rays white........

63. PERITYLE, p. 164.

Pappus of both bristles and awned paleae: rays purple or fleshcolor. 79. NICOLLETIA, p. 207.

Pappus of lacerate paleae: rays purple, linear.

Hulsea heterochroma, p. 202.

Rays yellow: pappus paleaceous except in no. 67 .

Herbage white-woolly, at least when young.

Pappus of numerous barbellulate bristles, united at base 67. SYNTRICHOPAPPUS, p. 176.

Pappus paleaceous, the paleae entire to fimbriate.

Rays persistent, becoming papery: desert perennial.

61. PSILOSTROPHE, p. 162.

Rays deciduous, not becoming papery.

Involucral bracts in 1 series.

70. ERIOPHYLLUM, p. 180.

Involucral bracts in 2 series..........74 HULSEA, p. 200.

Herbage glabrous or pubescent but never woolly.

Involucral bracts erect, in 2 series....76. HYMENOXYS, p. 203.

Involucral bracts closely reflexed.

77. HELENIUM, p. 205. 


\section{Pappus none.}

Herbage not white-woolly.

Flowers yellow: rays present.

Leaves pinnately parted into linear lobes: low annual.

..78. BLENNOSPERMA, p. 206.

Leaves denticulate or entire: tall perennial

60. VENEGASIA, p. 162.

Flowers white or purplish: rays wanting: leaves pinnately parted.... Chaenactis artemisiaefolia, p.

Herbage white-woolly, at least when young.

Ray-corollas with a toothed appendage at orifice opposite the ligule.

66. MONOLOPIA, p. 175.

Ray-corollas without appendage.

Rays yellow, persistent, becoming papery....62. BAILEYA, p. 163. Rays yellow, deciduous. 70. ERIOPHYLLUM, p. 180.

Rays purple or flesh-colored, deciduous.

Syntrichopappus Lemmoni, p. 177.

\section{Tribe 8. anthemideaE. Mayweed Tribe.}

Mostly strong-scented or aromatic plants. Leaves alternate, all or some of them finely dissected, pinnately parted, or pinnatifid, except in a few species. Bracts of the involucre imbricated, commonly dry and scarious or with scarious margins. Receptacle naked, or pubescent, or with chaff-like bracts. Flowers white, yellow, or greenish, either all perfect or the outer ones pistillate or neutral. Rays present or none. Anthers not eaudate. Style-branches of pistillate flowers obtuse or truncate, destitute of appendage. Pappus none or a short scarious crown. Receptacle chaffy: heads radiate.

Heads solitary: rays 10 to 20 83. ANTHEMIS, p. 210.

Heads in a terminal cyme: rays 4 to 6 84. ACHILLEA, p. 211. Receptacle naked (except in Artemisia Palmeri): heads discoid.

All of the flowers with corolla.

Heads solitary terminating leafy branches or peduncles: receptacle conical. .85. MATRICARIA, p. 212.

Heads in panicled racemes or spikes: receptacle nearly flat. 88. ARTEMISIA, p. 215.

Marginal flowers destitute of corolla: receptacle nearly flat.

Heads peduncled: style deciduous.

86. COTULA, p. 213.

Heads sessile: achenes pointed with the spine-like persistent style...

87. SOLIVA, p. 214. 


\section{- Tribe 9. SENECIONEAE. Groundsel Tribe.}

Herbs and shrubs, or a few species arborescent. Leaves mostly alternate or radical (opposite in Arnica). Heads either discoid or radiate. Involucre mostly of a single series of similar bracts, sometimes with an outer calyculate series, rarely imbricated in several series (e.g., Lepidospartum). Receptacle nearly always naked. Anthers mostly rounded at base. Style-branches of hermaphrodite flowers usually flat, the truncate tips pencillate, and the stigmatic lines (which are near the margins) not meeting. Pappus of numerous fine bristles, rarely subpaleaceous. Pappus plumose: alpine perennial with leaves all basal.

89. RAILLARDELLA, p. 221.

Pappus of slender bristles (or narrow paleae), never plumose.

Involucral bracts in 3 or 4 series, regularly imbricated: leaves nicstly reduced and scale-like. 90. LEPIDOSPARTUM, p. 221.

Involueral bracts in 1 or 2 series, not regularly imbricated: leaves conspicuous.

Leaves opposite: herbs

91. ARNICA, p. 222.

Leaves alternate (sometimes fascicled).

Pappus-bristles very unequal.

Style-tips not penicillate: narrow-leaved shrub

92. PEUCEPHYLLUM, p. 223.

Style-tips penicillate: broad-leaved herbs.

93. PSATHYROTES, p. 224.

Pappus-bristles nearly equal.

Bracts of the involucre 4 to 6 , rigid, overlapping.

94. TETRADYMIA, p. 226.

Bracts of the involucre more than 10, herbaceous, connivent but not overlapping. 95. SENECIO, p. 228.

Tribe 10. CYNAREAE. Thistle Tribe.

Thistles or thistle-like herbs with alternate mostly prickly leaves. Heads large, homogamous, the flowers all perfect, or sometimes heterogamous, the marginal flowers then radiatiform and commonly neutral. Bracts of the involucre imbricated, usually prolonged into a spine or bristle, or provided with a membranous edge. Receptacle bristly or hairy, seldom with true bracts. Rays none. Corollas tubular, cleft into long narrow lobes. Anthers with elongated appendage at the tip, caudate at 
the base. Style-branches short, commonly united up to the obtuse tips, commonly with a pubescent ring below. Pappus bristly or plumose, rarely paleaceous or wanting.

Achenes inserted on the receptacle by their very base.

Filaments distinct.

Pappus rough but not plumose: involucral bracts with uncinate tips 96. ARCTIUM, p. 236.

Pappus plumose: involucral bracts not uncinate.

Receptacle dry: native species. 97. CARDUUS, p. 236.

Receptacle fleshy-thickened: garden escapes....98. CYNARA, p. 243. Filaments united below into a tube. ..99. SILYBUM, p. 242. Achenes obliquely inserted on the reeptacle........100. CENTAUREA, p. 243.

\section{Tribe 11. mutisieae. Mutisia Tribe.}

Herbs and shrubs or rarely twining or arborescent plants, restricted almost entirely to Mexico and South America. Leaves alternate. Receptacle mostly naked. Heads in our genera homogamous, the flowers all perfect and the corolla bilabiate. Anthers with long tails at base; anther-tips also elongated. Stylebranches of perfect flowers not appendaged, usually short and blunt, without node below.

Flowers rose-color or white: receptacle naked. 101. PEREZIA, p. 245.

Flowers yellow: receptacle villous. 102. TRIXIS, p. 245.

\section{Tribe 12. CiChorieaE. Chicory Tribe.}

Herbs and low shrubs (except two austral genera of trees) with milky juice and alternate or radical leaves. Receptacle naked or with chaff-like bracts, nearly always plane. Heads homogamous. Flowers hermaphrodite and with ligulate corolla; ligule 5-toothed at the truncate apex; corollas, after flowering, twisted into a cap-like mass which remains on the achenes or involucre for some time. Anthers sagittate or auricled at base, commonly with thin rather short appendages at summit. Pollengrains usually 12-sided. Style-branches semi-cylindric, narrowed towards the ends, stigmatic on their inner side for their whole length. Achenes often excavated at base, the border surrounding a short stipe. 


\section{A.-Pappus either none or paleaceous, never plumose.}

Achenes destitute of pappus. 104. ATRICHOSERIS, p. 246.

Achenes with paleaceous pappus.

Flowers blue; paleae truncate, destitute of awn

103. CICHORIUM, p. 246.

Flowers yellow.

Involucral bracts plane; paleae all awn-tipped

105. MICROSERIS, p. 247.

Involueral bracts concave, enfolding marginal achenes; alternate paleae of central achenes awn-tipped.

106. RHAGADIOLUS, p. 252.

\section{B.-Pappus of plumose bristles.}

Receptacle paleaceous or with soft slender bristles among the flowers: leaves all radical.

Involucral bracts with broad membranous margins, the outermost ones orbicular. 107. ANISOCOMA, p. 253.

Involucral bracts herbaceous, all narrow. 108. HYPCHOERIS, p. 254.

Receptacle naked: leaves radical or cauline.

Achenes truncate at apex, not beaked....109. STEPHANOMERIA, p. 255.

Achenes beaked.

Leaves pinnatifid

110. RAFINESQUIA, p. 261.

Leaves narrow, entire. 111. TRAGOPOGON, p. 262.

\section{C.-Pappus of capillary bristles, never plumose or paleaceous.}

Achenes not flattened.

Plants caulescent, the more or less leafy stems branching above and bearing several to numerous heads.

Pappus promptly deciduous ( 1 or 2 persistent bristles in some species), some or all of the bristles united at base and falling away in a ring.

Achenes beakless, truncate: no tack-shaped glands.

112. MALACOTHRIX, p. 262.

Achenes beaked.

Inflorescence with tack-shaped glands: achenes gradually narrowed above 113. CALYCOSERIS, p. 269.

Inflorescence not glandular: achenes truncate, short-beaked 114. GLYPTOPLEURA, p. 271.

Pappus tardily deciduous, the bristles falling separately, or persistent.

Achenes truncate at the broad summit.

Flowers rose-colored: involucral bracts 4 or 5 .

118. LYGODESMIA, p. 275.

Flowers yellow or white: involucral bracts 10 or more 121. HIERACIUM, p. 283.

Achenes narrowed to the summit. 120. CREPIS, p. 280. 
Plants acaulescent, with simple scapes, the heads therefore solitary and leaves radical.

Achenes beakless, broad and truncate at summit

Malocothrix Californica, p. 264.

Achenes beaked.

Achenes muricate-roughened above......115. TARAXACUM, p. 272.

Achenes smooth or 10-ribbed; the ribs either straight or wavy, but not muricate. 119. TROXIMON, p. 275.

Achenes flattened: leafy-stemmed plants.

Achenes beaked

117. LACTUCA, p. 274.

Achenes truncate, not beaked 116. SONCHUS, p. 272.

Tribe 1. eUPatorieaE. Eupatory Tribe.

1. HOFMEISTERIA Walp.

Suffrutescent desert plants. Lower leaves opposite, the upper alternate. Heads medium-sized, long-pedunculate or nearly sessile, many-flowered. Involucre campanulate; bracts narrow, striate, the outer ones successively shorter. Receptacle naked. Achenes 5-angled by the strong nerves, callous-thickened at base. Pappus of 2 to 12 (in ours 10 to 12) scabrous bristles and in addition a series of shorter thin paleae.

1. H. pluriseta Gray, Pacif. R. Rept. iv. pt. 5, 96, t. 9 (1857).

Stems decidedly woody, intricately much branched, forming bush-like plants usually 3 to $6 \mathrm{dm}$. high: herbage glandularpuberulent: leaves 1 to usually $3 \mathrm{~cm}$. long; petiole flat or canaliculate at least toward the base, 1 to $4 \mathrm{~cm}$. long; blade less than 7 $\mathrm{mm}$. long, deltoid to lanceolate or linear, acute at apex, tapering at base, entire or with 1 or 2 small teeth, the whole blade often so small as to appear merely as the dilated and flattened tip of the petiole: bracts of the inflorescence linear-subulate: involucre 7 to $9 \mathrm{~mm}$. high, about 20 -flowered; bracts conspicuously 3 -striate, with acuminate often recurved tip: pappus of 10 to 12 bristles equalling or somewhat exceeding the corolla and about as many narrow acute squamellæ, the latter sometimes bristle-tipped.

Rather common in cañons of the desert ranges, especially on rocky cliffs and in crevices of rocks: Inyo Mts.; Palm Cañon; Palm Springs; Newberry; Inyo Mts.; Panamint Mts.; to Utah and Arizona. 
H. viscosa A. Nelson, Bot. Gaz. xxxvii. 263 (1904), of Southern Nevada, is described as differing from our species mainly in having its heads congested in capitate clusters.

\section{MALPERIA Wats.}

An erect desert annual with the aspect of Chaenactis. Leaves alternate, sessile except the lowermost, narrow. Heads on short peduncles, loosely cymose, several to many-flowered. Involucre turbinate; the narrow bracts thin and very unequal, severalnerved. Receptacle naked, flat. Corolla narrow-cylindric with short erect lobes. Anther-tips ovate, obtuse. Style-branches filiform, obtuse, thickened and exserted at maturity. Achenes pentagonal, slender. Pappus of 3 hispidulous setae as long as the corolla alternating with minute truncate erose paleae.

1. M. tenuis Wats., Proc. Am. Acad. xxiv. 54 (1889).

Slender, cymosely branching, 1.5 to $4 \mathrm{dm}$. high: herbage minutely scabrous: leaves linear, acuminate, 2 to $5 \mathrm{~cm}$. long, entire (or with a few teeth, ace. to Watson): involucre 8 to 10 $\mathrm{mm}$. high; bracts linear, the inner acuminate, all scarious-margined, pubescent on the back: achenes slightly hispid on the angles.

Los Angeles Bay, Lower California Palmer, ace. to Watson; San Jose de Gracia, Lower California, Apr., 1889, Brandegee; Santa Gertrudis, Lower California, Mar., 1898, Orcutt; Signal Mt., near U. S. and Mexican boundary line, 1901, Brandegee; Split Mt., San Diego Co., California, Apr., 1905, Brandegee.

\section{BRICKELLIA Ell.}

Herbs or undershrubs (all the California species woodystemmed perennials). with opposite or alternate veiny leaves. Heads small or medium-sized. Involucre cylindric to campanulate, 5 to 50-flowered; bracts chartaceous or membranous, striate, the outer ones successively shorter in most species. Receptacle naked. Corollas white or whitish, slender, 5-toothed at summit, the teeth mostly glandular externally. Achenes 10costate. Pappus a single series of scabrous or plumose eapillary bristles. 
Heads solitary, terminating corymbose branchlets, eampanulate, 30 to 50 flowered.

Leaves ovate, mostly with broad base.

Herbage green: leaves sharp-pointed

1. B. atractyloides.

Herbage white-tomentose: leaves not pointed

2. B. incana.

Leaves linear to oblong or obovate, with narrow base.

Inner involucral bracts with acuminate tips: leaves acute, mostly 15 to $30 \mathrm{~mm}$. long 3. B. linifolia.

Inner involucral bracts acute: leaves obtuse, mostly 5 to $15 \mathrm{~mm}$. long 4. B. frutescens.

Heads loosely paniculate or glomerate, turbinate, 5 to 25 -flowerd (or perhaps more in no. 5).

Involucral bracts acute, loose: herbage tomentose.

5. B. Nevinii.

Involucral bracts obtuse, erect: herbage lightly if at all tomentose.

Heads 10 to 15 -flowered: leaves ovate

6. B. Californica.

Heads about 5-flowered: leaves lanceolate.

7. B. Knappiana.

1. B. atractyloides Gray, Proc. Am. Acad. viii. 290 (1870). Coleosanthus atractyloides Kuntze, Rev. i. 328 (1891). C. venulosus A. Nelson, Bot. Gaz. xxxvii. 262 (1904).

About $3 \mathrm{dm}$. or less high: stems woody, rigid, with numerous short twiggy branches: herbage minutely pubescent and usually also glandular, the foliage green and scabrous-atomiferous: leaves rigid-coriaceous, 3-nerved and reticulate-veined, all alternate, subsessile, ovate-acuminate, rounded or truncate at base, either entire or with a few spinulose teeth, 1 to $3 \mathrm{~cm}$. long, 7 to $20 \mathrm{~mm}$. broad: heads solitary terminating the branchlets; peduncle commonly naked and exceeding the leaves, sometimes bracteate near the summit: involucre campanulate, 35 to 50 flowered, 10 to $13 \mathrm{~mm}$. high; outer bracts green, ovate-acuminate, sometimes broad and toothed like the leaves, scarcely or not. shorter than the inner ones; inner bracts linear-lanceolate, acuminate.

Among rocks in the desert ranges: southwestern part of the Colorado Desert, San Diego Co., Apr., 1889, Orcutt; Vallecito, acc. to Parish; San Felipe, San Diego Co., May, 1899, Brandegee; Palm Springs, Parish, no. 210; Warren's, May, 1902, Brandegee; Cottonwood Springs, Hall, no. 6016; northern slope San Bernardino Mts. (borders of Mohave Desert), Parish, no. 3710 ; Ord Mts., Hall \& Chandler, no. 6775 ; Providence Mts., Mav, 
1902, Brandegee; Inyo Mts., Austin, no. 565; a frequent and characteristic plant in the clefts of rocks within the Lower Sonoran Zone from the Inyo Mts. east into Nevada, ace. to Coville; Fort Mohave, Arizona, Lemmon; Nevada, Purpus, no. 6022; St. George, Utah, Goodding, no. 803; Southern Nevada, Goodding, no. 678 , acc. to Nelson (as Coleosanthus venulosus, the identity of which with $B$. atractyloides has been pointed out by Robinson). ${ }^{4}$

2. B. incana Gray, Proc. Am. Acad. vii. 350 (1868). Coleosanthus incanus Kuntze, l.c.

Three to $6 \mathrm{dm}$. or more high, loosely branched from a suffrutescent base: herbage white with a close tomentum which is deciduous from the stems, exposing the white bark: leaves alternate, sessile, ovate or broader with roundish or subcordate base, obtuse to acute but not pointed, entire or the margins sinuate, 1 to $3 \mathrm{~cm}$. long: heads 40 to 50 -flowered, eampanulate, solitary and terminal on the branchlets: involucre broadly campanulate, 15 to $20 \mathrm{~mm}$. high ; bracts firm-chartaceous, regularly imbricated; short outer ones ovate, obtuse; inner ones linear-lanceolate, acute: achenes 9 or $10 \mathrm{~mm}$. long, cinereous-pubescent.

Dry gravelly soil of the Mohave Desert, especially in sandwashes of the Lower Sonoran Zone: Cushenberry Springs, Parish, nos. 1248, 2388; Providence Mts., Cooper, ace. to Gray, also Brandegee; near the Needles, Brandegee; Ash Meadows, Nevada, Purpus, no. 6041; reported from Chuckawalla Bench, Colorado Desert, California, by the Riverside Botanical Club.

3. B. linifolia Eaton, Bot. King Exped. 137, t. 15, ff. 1 to 6 (1871). B. Mohavensis Gray, Syn. Fl. i. pt. 2, 104 (1884). Coleosanthus linifolius Kuntze, l.c.

Stems numerous, leafy, ascending or erect, forming roundtopped elumps 2 to $4 \mathrm{dm}$. high : herbage cinereous-pubescent and also somewhat glandular at least above: leaves from broadly oblong with narrow base to linear or spatulate, acute, entire or with 1 or 2 short teeth, 1.5 to $3.0 \mathrm{~cm}$. long, only the midnerve prominent: heads 30 to 50 -flowered, scattered, the peduncles exceeding the leaves : involucre campanulate, 12 to $14 \mathrm{~mm}$. high; bracts

4 Proc. Am. Acad. xlii. 47 (1906). 
2 to 4-nerved, linear, acute to attenuate, the inner with very slender tips: achenes cinereous-hispidulous on the ribs.

Western borders of the Colorado Desert, in Riverside Co., Hall, nos. 1888, 2142; southern borders of the Mohave Desert, May, 1882 , no. 1247 , Parish (type of $B$. Mohavensis Gray), also Jun. 17, 1894 and no. 3711, Parish; Providence Mts., Brandegee; Inyo Co., Purpus; thence to Utah and Arizona.

B. Mohavensis is described by Gray as having "bracts of the involucre obtuse." Through the kindness of Dr. Robinson I have had the opportunity of examining a head from the type sheet in the Gray Herbarium and although the bracts (especially the outer ones) are somewhat broader and less acute than in typical $B$. linifolia, the difference is not sufficiently great to be of specific value. Moreover, specimens collected by Parish (Rose Mine, Jun. 17, 1894; and north slope San Bernardino Mts., no. 3711) near the type locality of $B$. Mohavensis have the slender bracts of $B$. linifolia, and this character is somewhat variable even in collections from Utah, whence came the original $B$. linifolia. The pubescence, pappus, and achenes, likewise fail to yield constant characters for the separation of B. Mohavensis.

4. B. frutescens Gray, Proc. Am. Acad. xvii. 207 (1882). Coleosanthus frutescens Kuntze, 1. c.

A rigid shrub with divaricate often spinose branches : herbage cinereous-pubescent: leaves all alternate, linear-spatulate to obovate, obtuse, entire, .5 to $1.5 \mathrm{~cm}$. long: heads scattered, about 35 -flowered (about 20-flowered, ace. to Gray): involucre campanulate, 9 to $12 \mathrm{~mm}$. high; bracts 2 to 4-nerved, acute or rather obtuse, the short and oblong outer ones somewhat greenishtipped: achenes hispidulous-scabrous: pappus-bristles minutely serrulate.

Lower Sonoran Zone: San Felipe, western borders of the Colorado Desert, Parish, Purpus, etc.; Mountain Springs, San Diego Co., Vasey, acc. to Gray; Lower California.

5. B. Nevinii Gray, Proc. Am. Acad. xx. 297 (1885). Coleosanthus Nevinii Heller, Cat. N. Am. Pl. ed. 1, 8 (1898).

Stems slender, long, loosely branched: herbage white-tomentose, the tomentum becoming loose and scurfy, especially on the 
stems : leaves alternate, ovate, subcordate and closely sessile, or euneate at base, acutish, coarsely few-toothed or entire, $1.5 \mathrm{~cm}$. or less long: heads about 25-flowered (30 to 40 -flowered, acc. to Gray), solitary, terminating short branchlets of an open panicle, the upper ones loosely glomerate: involucre narrowly turbinate, 10 to $12 \mathrm{~mm}$. high, green after the fall of the tomentum; bracts linear, acute, the outer regularly shorter and with spreading or recurved tips; the inner with erect acuminate tips: achenes minutely pubescent.

Upper Sonoran Zone on the coastal slope: first collected near Newhall by Nevin; crevices of eliffs, San Francisquito Cañon, ace. to Parish; Santa Monica Range, above Sherman, Braunton, no. 517, and Greata, no. 331; near Pasadena, acc. to McClatchie; San Antonio Cañon, near Claremont, Baker, no. 3731 ("in low dense tufts on a woody base, occasional along stony bottom of wash").

Writing of the station above Sherman Mr. Braunton says: "It must have been introduced at this station within the past few years. In 1901 there were but few large plants and many small ones. Now (1902) it is common for a mile square and bids fair to extend everywhere in the hills."

6. B. Californica (T. \& G.) Gray, Pl. Fendl. 64 (1849). Bulbostylis Californica T. \& G., Fl. ii. 79 (1841). Coleosanthus Californicus Kuntze, l. c.

A straggling moderately branched bush, 5 to $10 \mathrm{dm}$. high: herbage minutely puberulent to thinly tomentose: leaves alternate, ovate, crenate-dentate, mostly 2 to $4 \mathrm{~cm}$. long, short-petiolate, usually with broad truncate or subcordate base but the small upper ones narrowed to the petiole: heads in small clusters terminating lateral branchlets of the leafy panicle, or the branchlets very short, the inflorescence then an interrupted strict thyrsus: involucre 9 to $11 \mathrm{~mm}$. high, 10 to 15 -flowered; outer bracts roundish, very obtuse; inner bracts narrower, the innermost linear and somewhat acute.

Common in gravelly stream beds and on chaparral slopes of the Upper Sonoran Zone west of the mountains from San Diego Co. and Lower California north to Mendocino and the Sierra Nevada foothills. Also in Arizona and Nevada, acc. to Gray, Aug.-Nov. 
Var. desertorum (Coville) Parish, in MS., comb. nov. $B$ : desertorum Coville, Proc. Biol. Soc. Wash. vii. 68 (1892). Coleosanthus desertorum Coville, Contr. U. S. Nat. Herb. iv. 119 (1893). Smaller in all its parts: branches slender, becoming glabrous in the second or third year, but still with a white epidermis, afterward gray : leaves only $16 \mathrm{~mm}$. or less long even on vigorous shoots (mostly less than $1 \mathrm{~cm}$.) : heads in glomerules terminating short lateral branchlets: involucre 7 to $9 \mathrm{~mm}$. high.Between Banning and Seven Palms (Colorado Desert), Orcutt, acc. to Coville; Inyo Co., ace. to Coville; Dos Cabesas, in the southwestern part of the Colorado Desert, Orcutt, no. 1464; Riverside, Zumbro, no. 362. Although from the coast side of the mountains, Mr. Zumbro's specimens answer very well for var. desertorum except that the stems are of a dull white; the heads are in loose glomerules terminating lateral branchlets 1 to $3 \mathrm{~cm}$. long.

B. MICROPHYLLA SCABRA Gray may reach our northeastern border. Certain specimens collected by Brandegee in the Providence Mountains are probably of this species but they lack flowers. Much like $B$. C. desertorum but outer bracts with greenish somewhat spreading tips, the outermost ones wholly herbaceous.

7. B. Knappiana Drew, Pitt. i. 260 (1888). Coleosanthus Knappianus Greene, Eryth. i. 54 (1893).

A slender willow-like shrub, $2.5 \mathrm{~m}$. or less high the ascending branches with a smooth white bark which has a tendency to split and become shreddy: branchlets and upper leaves hispidulousscabrous, somewhat glutinous: leaves alternate, ovate-lanceolate, acute, narrowed to a distinct petiole, sharply and saliently toothed or some of the upper ones entire, 3 to $4 \mathrm{~cm}$. long: heads about 5 flowered, in glomerules terminating lateral branchlets of the open leafy panicle: involucre turbinate, about $7 \mathrm{~mm}$. high; bracts linear to oblong, obtuse, regularly imbricated, the quter successively shorter, 3-nerved: achenes rather densely but minutely appressed-setulose, indistinctly nerved.

"In the neighborhood of the Mohave River," Sept., 1888, II. A. Knapp; Pleasant Cañon, Panamint Mts., Hall \& Chandler, no. 6919. Further collections may show that this is only a 
form of $B$. multiflora Kell. (and both of these are too near to $B$. longifolia Wats.), differing only in its serrate leaves, scabrous herbage, and more densely pubescent achenes.

Eupatorium GLANDULOSUm HBK. was gathered from the wet bank of a pool in a cañon south of Pasadena in 1896 by $M c$ Clatchie. Since it has not been found elsewhere in Southern California it is probably an introduction from Mexico. E. Pasadenense Parish, Zoe v. 75 (1900), was founded on McClatchie's specimens, but one of these has been submitted to Dr. B. L. Robinson, who identifies it with E. glandulosum, and writes: "I have compared it very earefully with material from the uplands of Mexico, from Jamaica, and with a photograph which I took of the type in the Paris Herbarium; also with cultivated specimens of $E$. trapezoideum Kunth, a species which I cannot distinguish from the earlier $E$. glandulosum. There is a moderate amount of variation in the size, thinness, and degree of glandularity of the leaves but the form of the leaves, nature of the pubescence, character of the involucre, corollas, achenes, pappus, etc., are in all respects constant and identical between $E$. Pasadenense and E. glandulosum."

E. sagGittatum Gray, although in Coulter's "California" collection, is not a member of our flora. According to Gray it is Mexican, probably reaching into Arizona.

\section{Tribe 2. AStereaE. Aster Tribe.}

\section{GUTIERREZIA Lag.}

Low suffrutescent or herbaceous plants with nearly glabrous but resinous herbage. Leaves narrowly linear, entire, alternate. Heads radiate, very small, numerous, cymose or paniculate at the summit of the stems. Involucre imbricated; the bracts coriaceous, with green tips. Receptacle in our species flat. Flowers yellow. Achenes angled or striate, pubescent. Pappus of 4 to 15 oblong or narrower commonly erose paleae.

Heads clavate-oblong: flowers of disk and ray 1 or 2 each 1. G. lucida. Heads clavate-oblong: flowers of disk and ray 3 to 7 each......2. G. Sorothrae. Heads obovate-turbinate: flowers of disk and ray 7 to 12 each

3. G. Californica. 
1. G. lucida Greene, Fl. Fr. 361 (1897). Xanthocephalum lucidum Greene, Pitt. ii. 282 (1892). Gutierrezia Euthamiae microcephala Gray, Syn. Fl. i. pt. 2, 115 (1884), in part.

Straggling bush, $3 \mathrm{dm}$. or more high: herbage very resinous and of a clear yellowish-green color: foliage sparse and lax: inflorescence cymose-paniculate; the numerous heads glomerate at the ends of the slender twigs: involucre narrow, $3 \mathrm{~mm}$. high; bracts closely appressed, with obscure greenish tips.

Confined chiefly to dry hills of the Mohave Desert (and southward?) : Indian Wells, Kern Co., M. A. Knapp; Cottonwood Creek, Inyo Co., Purpus, no. 3025; Santa Monica Range, Hasse, acc. to Parish.

2. G. Sarothrae (Pursh) Britton \& Rusby, Trans. N. Y. Acad. vii. 10 (1887). Solidago Sarothrae Pursh, Fl. 540 (1814). Brachyris Euthamiae Nutt., Gen. ii. 163 (1818). Gutierrezia Euthamiae T. \& G., Fl. ii. 193 (1841). G. divergens Greene, Pitt. iv. 58 (1889), in part.

Bushy plant with numerous erect stems from a woody base, 3 to $6 \mathrm{dm}$. high: inflorescence eymose-paniculate; heads shortpeduncled or sometimes in terminal glomerules of 3 to 5 : involucre clavate-oblong, 3 or $4 \mathrm{~mm}$. high; bracts with minute green tips : disk and ray-flowers each 3 to 7 : achenes sericeous-pubescent.

Arid plains and rocky hills of the Upper (and Lower?) Sonoran Zone almost throughout western North America and by far the most abundant species in our district: San Fernando Valley, Barber, no. 170; San Jacinto Mts., Vandeventer, no. 10; Jamul Valley, San Diego Co., Palmer, no. 127; Mission Valley, San Diego, Oet. 1, 1883, Orcutt, no. 991.

3. G. Californica (DC.) T. \& G., Fl. ii. 193 (1842). Brachyris Californica DC., Prodr. v. 313 (1836). G. divergens Greene, Pitt. iv. 58 (1899), in part.

Stems more loosely branched above than in G. Sarothrae: heads larger and broader, hence obovate-turbinate, mostly seattered in the panicles or in an open cyme (rarely somewhat glomerate) : involucre 4 or $5 \mathrm{~mm}$. high and fully as broad at the summit: bracts with conspicuous green tips, the inner ones very abtuse: achenes densely silky. 
Dry hills from Arizona and the Colorado Desert north to San Francisco Bay, mostly in the Sonoran zones: Coyote Cañon, Riverside Co., Hall, no. 2871; Griffith Park, Los Angeles, Braunton, no. 570; Bear Valley, San Bernardino Mts., Parish, no. 1455 ; etc.

Var. bracteata (Abrams) Hall, comb. nov. G. bracteata Abrams, Bull. Torr. Club xxxiv. 265 (1907). Branchlets strongly divaricate or even geniculate, with numerous bract-like leaves, or these deciduous: heads few and large, solitary._- "Southwestern part of the Colorado Desert, Nov. 1889'" (between Banning and Seven Palms, acc. to Abrams), Orcutt.

\section{AMPHIACHYRIS Nutt.}

Ours a low desert shrub with alternate entire leaves and glabrous herbage. Heads heterogamous; ray-flowers yellow, pistillate, fertile; disk-flowers yellow, hermaphrodite-sterile. Involucre imbricated; bracts thin, only the medial portion herbaceous. Style-appendages lanceolate. Fertile achenes pubescent. Pappus of ray-flowers, in our species, of few and short squamellae coalescent at base; of disk-flowers of 5 to 20 weak bristles, more or less dilated and united at base, nearly equalling the corolla.

1. A. Fremontii (T. \& G.) Gray, Proc. Am. Acad. viii. 633 (1873). Amphipappus Fremontii T. \& G., Jour. Bost. Soc. Nat. Hist. v. 108 (1845); Gray, Pl. Fremont. 17, t. 9 (1853).

Decidedly shrubby, 3 to $6 \mathrm{dm}$. high, with rigid divaricate branches; bark white after the first season: leaves obovate or elliptic, acute, narrowed to the sessile base or short petiole, 5 to $12 \mathrm{~mm}$. long: heads glomerate, the glomerules terminating short branches of a compound terminal leafy-bracted cyme: involucre ovoid, $4 \mathrm{~mm}$. high; outer bracts narrow; inner bracts broadly oblong, very obtuse, thin, appressed and more or less cohering: rays 1 or 2 , about $2 \mathrm{~mm}$. long: disk-flowers 3 to 6 .

Lower Sonoran Zone, from near our northern borders into Inyo Co., east to Nevada and Utah: "on the Mohave River and other tributaries of the Colorado,' Fremont, acc. to Gray ; eastern Inyo Co. and Nevada, ace. to Coville; Slate Range and Panamint Mts., Hall \& Chandler, nos. 6908, 7046; Argus Mts., Purpus, no. 5326 . 


\section{GRINDELIA Willd. Gum Plant.}

Coarse herbs or suffrutescent plants, the California species all perennials. Basal leaves commonly petioled; the cauline sessile by a broad base. Herbage in ours glabrous or nearly so but balsamic-viscid. Heads gummy, medium-sized or large, in panicles or cymes, rarely solitary or sessile, ours with conspicuous yellow rays. Involucre campanulate or hemispheric; the bracts many-ranked, firm-herbaceous, often with attenuate squarrose points. Style-appendages lanceolate or linear. Achenes short, truncate, compressed or turgid, glabrous. Pappus of 2 to 8 awns or small scales, very readily deciduous. Involucral cups of the budding heads often completely filled with the white or cream-like gummy exudation, and it is probably this gum, also present in the leaves, that gives to the genus its reputed medicinal value.

Leaves 2 to $8 \mathrm{~cm}$. wide: insular species.

1. G. latifolia.

Leaves narrower, sometimes linear, rarely over 2 or $3 \mathrm{~cm}$. wide.

Stems woody below: leaves linear-oblanceolate or cuneate: salt-marsh species. 2. G. cuneifolia.

Stems herbaceous throughout.

Involucre 20 to $25 \mathrm{~mm}$. broad: cauline leaves 1 to $3 \mathrm{~cm}$. wide 3. G. róbusta.

Involucre 10 to 15 (rarely 20) $\mathrm{mm}$. broad: cauline leaves .5 to $1.5 \mathrm{~cm}$. wide.

4. G. camporum.

1. G. latifolia Kell., Proc. Calif. Acad. v. 36 (1873); Greene, Pitt. i. 89 (1887).

Stout but herbaceous throughout, $4 \mathrm{dm}$. or more high: basal leaves elliptic or obovate, 5 to $15 \mathrm{~cm}$. long in addition to the winged petiole of equal length; cauline leaves broadly ovate or oblong, very obtuse, the base broad and clasping, 4 to $8 \mathrm{~cm}$. long, 1.5 to $5 \mathrm{~cm}$. broad, closely and regularly serrate: heads in leafybracteate cymes: involucre broadly hemispheric, 10 to $15 \mathrm{~mm}$. high, about $20 \mathrm{~mm}$. broad; outer bracts with slender recurved tips; inner bracts erect: rays about $1.5 \mathrm{~cm}$. long: pappus-awns 5 to 8 .

Santa Rosa Island, 1872 or 1873, Harford (type); Santa Rosa Island, Jun., 1888, Brandegee; San Miguel Island, Sept., 1886, Greene. These specimens were examined at the Herbarium 
of the California Academy of Sciences, where they have since been destroyed by fire, but there is a duplicate of Kellogg's type and a sheet of Brandegee's material from the type locality preserved in the Brandegee Herbarium at the University of California.

2. G. cuneifolia Nutt., Trans. Am. Philos. Soc. ser. 2, vii. 315 (1841) ; Perrédès, Wellcome Research Lab. Bull. 65, t. i, f. 6 (1907).

Plant 6 to $12 \mathrm{dm}$. high, commonly with several $\mathrm{dm}$. woody at base, ending in a cymose panicle of several heads or the simple sterile shoots densely leafy at summit: leaves thick, spatulate to narrowly oblong, usually obtuse but the upper sometimes broadest at base and acute (especially the much reduced ones of the flowering branches). entire or serrulate: involucre 12 to $18 \mathrm{~mm}$. broad; bracts with tips erect to recurved: rays golden-yellow: mature achenes mostly with a 1 or 2-dentate border at summit: pappusawns 5 to 8 .

Salt-marshes from Los Angeles Co. (ace. to Abrams) and Santa Barbara (acc. to Gray) northward. I have seen no specimens from Southern California. Autumn.

3. G. robusta Nutt., Trans. Am. Philos. Soc., ser. 2, vii. 314 (1841); Perrédès, l. c. f.l. Gum Plant.

Stems mostly erect, 3 to $6 \mathrm{dm}$. high : leaves usually oblong to ovate or lanceolate and acute, in a few cases wider above and obtuse, sharply serrate or denticulate or the uppermost entire; the middle cauline 3 to $5 \mathrm{~cm}$. long, 1 to $3 \mathrm{~cm}$. wide: heads few, in a terminal cyme, sessile and leafy-bracted, or pedunculate and the bracts less obvious : involucre 20 to $25 \mathrm{~mm}$. broad; bracts with attenuate squarrose or recurved tips: mature achenes mostly with a 1 or 2-dentate, often oblique border at summit: pappus-awns 2 to 8 .

Along the seaboard from Los Angeles to San Francisco, not plentiful; first collected by Nuttall at San Pedro; Summerdale, Santa Barbara Co., Hall, no. 3175; Suey River, near the northern boundary of Santa Barbara Co., May 9, 1896, Miss Eastwood. Summer. 
4. G. camporum Greene, Man. Bot. Reg. S. F. Bay 171 (1894) ; Fl. Fr. 361 (1897); Perrédès, l. c. ff. 2, 4.

Stems several, erect, 3 to $6 \mathrm{dm}$. high, herbaceous throughout: basal leaves commonly numerous, oblanceolate-spatulate, obtuse, serrate, $10 \mathrm{~cm}$. or less long, 1 to $1.5 \mathrm{~cm}$. broad; cauline leaves oblanceolate or oblong, mostly acute, $5 \mathrm{~cm}$. or less long, .5 to 1.5 $\mathrm{cm}$. wide: heads rather numerous in an open leafy panicle: involucre 10 to 15 or $20 \mathrm{~mm}$. broad; the short outer bracts linearsubulate, squarrose-deflexed; inner bracts lanceolate-subulate, with spreading tips or erect: mature disk-achenes compressed, minutely biauriculate or unidentate at summit: pappus-awns 2 or 3 or more.

In heavy clay soil, from San Diego Co. to middle California : National City, San Diego Co., Jul. 3, 1885, Cleveland; mesa north of San Diego, Chandler, no. 5358; Ramona, Jul. 10, 1903, Brandegee; Cuyamaca Mts., Jul. 8 and Oct. 15, 1894, Brandegee, also (at Julian) Chandler, no. 5460; Inglewood, Los Angeles Co., Hall, no. 6726; Elizabeth Lake, Los Angeles Co., Hall, no. 6719. Abundant on adobe mesas from University Station, Los Angeles, south and west, whence gathered for the wholesale drug trade. Summer.

\section{PENTACHAETA Nutt.}

Low and very slender annuals with narrowly linear and entire alternate leaves. Heads small, solitary or somewhat clustered at the ends of more or less naked branches, nodding in the bud. Receptacle convex. Involucre turbinate-campanulate, its bracts in 2 series, narrowly oblong, thin or membranous, scariousmargined, mucronulate, appressed. Disk-corollas yellow or rosered, very slender; rays white, pink, yellow, or none. Achenes oblong, flattened, hirsute-pubescent. Pappus of 5 to 12 slender bristles, often much reduced, or all obsolete.

Involucre glabrous, its bracts very unequal.

.. P. aurea. Involucre pubescent, its bracts nearly equal

2. P. Lyoni.

1. P. aurea Nutt., Trans. Am. Philos. Soc. ser. 2, vii. 336 (1841).

Diffusely branched, 1 to $3 \mathrm{dm}$. or more high (6 dm. high and 
leaves $5 \mathrm{~cm}$. long in exceptional $\operatorname{cases}^{5}$ ): herbage minutely and sparsely pubescent or nearly glabrous : involucre 5 to $7 \mathrm{~mm}$. high. glabrous; bracts imbricated, broadly linear or lanceolate, acute or acuminate, with green middle portion and scarious margins: rays commonly 10 to 40 , linear to oblong, golden-yellow, 5 to 10 $\mathrm{mm}$. long; disk-corollas irregular, the lobe nearest the ray-flowers being more acute than the others and more spreading, the sinus on each side of it continued further down: pappus-bristles 5 to 8 .

Upper Sonoran and Lower Transition zones, from San Diego (the type locality, where first gathered by Nuttall) to the San Jacinto Mts. and San Luis Obispo Co. (acc. to Greene); Mohave Desert near Cajon Pass, acc. to Parish: frequent in some parts of its range, especially throughout the coastal slope of San Diego Co. Mrs. Brandegee has gathered dwarf forms at San Diego with the flowers reduced to 3 or 4 in the solitary head, which is then either discoid or with one or two ray-flowers; also floriferous forms with rays as high as 60 in number.

2. P. Lyoni Gray, Syn. Fl. i. pt. 2, 446 (1886).

Erect, simple below or branched throughout, 1 to $5 \mathrm{dm}$. high : herbage lightly pubescent, at least the stems glabrate : leaves 2 to $5 \mathrm{~cm}$. long: involucre about $5 \mathrm{~mm}$. high, conspicuously hirsute with slender hairs; bracts nearly equal, linear, acute to subulateacuminate, with green midrib and scarious margins: flowers golden-yellow: pappus-bristles varying from 8 to 12 in number, somewhat dilated at base.

At San Pedro and on Santa Catalina Island, Lyon, ace. to Gray; San Pedro, Mrs. Brandegee; Wilmington, Lyon; Santa Catalina Island, Brandegee; all of these localities being in the Coastal Subarea of Los Angeles Co.

P. PAleacen Greene, Bull. Calif. Acad. i. 189 (1885). Probably not distinct from $P$. Lyoni, but smaller and more slender in all its parts : involucre $3 \mathrm{~mm}$. high, minutely and sparsely pubescent; bracts nearly equal: pappus-bristles about 5, very slender but paleaceous-dilated at base.-Lower California: Santo Tomas, Orcutt, Purpus; Chocolate Creek, Brandegee.

P. Orcuttil Gray, Proc. Am. Acad. xxii. 309 (1887). Also near $P$. Lyoni: heads small: involucre villous-pubescent: ligules

sHall, Univ. Calif. Pub. Botany i. 130 (1902). 
short: pappus-bristles 8 to 10, capillary, not dilated at base, caducous.-Vallecito, northern Lower California, Orcutt, acc. to Gray. Both of these species to be expected in San Diego Co.

\section{ACAMPTOPAPPUS Gray.}

Low round-topped desert shrubs with slender rigid stems and entire alternate leaves. Heads spherical, 12 to 36 -flowered, discoid or radiate. Involucral bracts closely imbricated in about 3 series, very broad and obtuse, pale, the margins thin-scarious and erose-fimbriate. Tube of disk-corollas funnelform; the lobes lanceolate, acute. Style-tips thick, subulate. Achenes shortturbinate, densely villous. Pappus of about 30 to 40 silvery awns, some of them flattened especially above and equalling the corolla, others setiform and shorter, all persistent.

1. A. sphaerocephalus Gray, Proc. Am. Acad. viii. 634 (1873). Haplopappus sphaerocephalus Gray, Pl. Fendl. 76 (1849) ; Torr., Pacif. R. Rept. vii. pt.3, 12, t.vi. (1856).

Herbage pale and glabrous or nearly so, the stems striate: leaves linear or linear-spatulate, acute, .5 to $2 \mathrm{~cm}$. long, sometimes fascicled: heads solitary terminating the branches, or in loose terminal clusters : involucre 6 to $8 \mathrm{~mm}$. high, its bracts commonly with a faint greenish subapical spot: rays none.

An exceedingly interesting plant, by no means rare in the Larrea and Yucca belts of the Desert Area (San Felipe, Chuckawalla, Palm Cañon, Antelope Valley, Owens Valley, etc.), extending eastward to Arizona and Utah.

A. Shockleyi Gray, the only other species, oceurs in southwestern Nevada (Shockley, ace. to Gray) and in the Inyo Mts.; California (Austin, no. 501). It is easily distinguished by its simpler monocephalous branches and larger heads with conspicnous yellow rays.

\section{HETEROTHECA Cass.}

Tall hairy herbs with alternate toothed leaves and radiate heads of yellow flowers in a terminal cymose panicle. Involucre hemispheric or broadly campanulate, its narrow bracts closely imbricated in many series. Both ray and disk-flowers numerous and fertile. Ray-achenes triangular-compressed with flat sides 
and narrow back; their pappus none or caducous. Disk-achenes compressed, silky-hirsute; their pappus double, the copious inner bristles long, capillary, and scabrous, the outer of short and stout bristles or scales.

1. H. grandiflora Nutt., Trans. Am. Philos. Soc. ser. 2, vii. 315 (1841). H. floribunda Benth., Bot. Sulph. 24 (1844). Diplopappus scaber Hook., Fl. Bor. Am. ii. 22 (1829), excl. syn.

Usually simple below, 5 to $20 \mathrm{dm}$. high : herbage villous-hispid or hirsute, the inflorescence viseid-glandular and strong-scented: leaves ovate, varying to elliptic or oblong, serrate; the radical and lower cauline long-petioled, the upper sessile, commonly with a pair of stipule-like lobes at base: heads numerous and in an open panicle when flowering in the autumn, few and scattered at other seasons: involucre 7 to $9 \mathrm{~mm}$. high : rays ábout 30 : pappus of disk-flowers as long or longer than the achene, in age brick-red, its outer series inconspicuous.

A common weed along ditches and in waste places, throughout Southern California except in the mountains.

It seems inadvisable to take up the name Heterotheca scabra for this species for, although Hooker's Diplopappus scaber antedates Nuttall's H. grandiflora by twelve years, it was assigned by Hooker in the belief that his plant was Pursh's Inula scabra ( $H$. subaxillaris Britt. \& Rusby), ${ }^{6}$ a mere transferral of the specific name being all that was intended. Moreover, De Candolle has used the name Heterotheca scabra for what now passes as $H$. subaxillaris, his description plainly applying only to that species, and since our plant has been known as $H$. grandiflora for some sixty-six years it is perhaps wise to interpret the rules somewhat loosely here in order to retain this name.

H. SUBAXILlaris (Lam.) Britton \& Rusby is to be expected along our eastern borders. Its stems are densely clothed above with broadly oblong subcordate-clasping leaves, these mostly without lobes at base: involucre somewhat canescent : outer pappus of disk-flowers conspicuous.

${ }^{6}$ H. subaxillaris Britton \& Rusby, Trans. N. Y. Acad. vii. 10 (1887). Inula subaxillaris Lam., Dict. iii. 259 (1789). I. scabra Pursh, Fl. il. 531 (1814). Chrysopsis scabra Nutt., Gen. ii. 15 (1818); Ell., Sketch ii. 339 (1824). H. Lamarchii Cass., Dict. Sei. Nat. xxi. 131 (1821). H. scabra DC., Prodr. v. 317 (1836). 


\section{CHRYSOPSIS Nutt.}

Perennial herbs, sometimes suffrutescent at base, with alternate entire leaves and either discoid or radiate heads of yellow flowers. Involucre campanulate to hemispheric, its bracts narrow and regularly imbricated. Style-appendages linear-filiform to subulate. Achenes compressed or turgid. Pappus brownish or ferruginous, of numerous capillary bristles with or without an outer row of short bristles or squamellae.

Rays present: pubescence hirsute or villous, eanescent.

1. C. villosa. Rays wanting: pukescence fine and soft, not canescent

2. C. Wrightii.

1. C. villosa (Pursh.) Nutt., Gen. ii. 150 (1818). Amellus villosus Pursh, Fl. ii. 564 (1814).

Rigid, erect, 3 to $9 \mathrm{dm}$. high: herbage canescently strigose or hirsute or hispid: spring leaves 3 to $5 \mathrm{~cm}$. long, oblong, narrowed to a margined petiole, early withering or deciduous; rameal leaves rigidulous, oblong, closely sessile, acute, mostly $2 \mathrm{~cm}$. or less long: heads variously paniculate or cymose, often nearly sessile, radiate: involucre about $8 \mathrm{~mm}$. high; bracts linear, acute, hirsutulous or almost smooth: achenes oblong-ovate, villous.

A northern species, represented in Southern California by the following varieties:

Var. echioides (Benth.) Gray, Syn. Fl., i. pt. 2, 123 (1884). C. echioides Benth., Bot. Sulph. 25 (1844). C. fastigiata Parish, Eryth. vii. 97 (1899), not Greene. A branching form as originally described, but commonly simple-stemmed up to the inflorescence: herbage canescently hispid: outer pappus conspicuous, white, squamellate; the squamellae very narrow, toothed at summit.-The common form in Southern California, extending north to the Sacramento Valley, plentiful in the Upper Sonoran Zone, occasionally also in the neighboring zones: Ramona, San Diego Co., Oct., 1903, Mrs. Brandegee; Witch Creek, San Diego Co., 1893, Alderson, also no. 721; Murietta, Parish, no. 2245; San Jacinto Mt., in the Transition Zone, Hall, no. 2607; Antelope Valley, Hall, no. 6713; Mt. Pinos, Hall, no. 6700.

Var. fastigiata (Greene) Hall, comb. nov. C. fastigiata Greene, Pitt. iii. 296 (1898). Stems rather densely clothed (ex- 
cept toward the base) with small ascending or suberect sessile leaves; these oblong to linear-spatulate, shortly acute or obtuse and mucronate, white (especially on the back) with a soft appressed-silky tomentum: no outer squamellate pappus but some of the outer bristles occasionally short.-Upper Sonoran Zone, apparently rare but perhaps overlooked by collectors, mistaking it for the common var. echioides: vicinity of San Bernardino, 300 to $450 \mathrm{~m}$. (1000 to $1500 \mathrm{ft}$.) alt., Oct. 15, 1895, Parish, no. 3815 ; San Bernardino Valley, Sept., 1892, Parish; near Claremont, Los Angeles Co., Baker, no. 3669.

Var. sessiliflora (Nutt.) Gray, Syn. Fl. i. pt 2, 123 (1884). C. Sessiliflora Nutt., Trans. Am. Philos. Soc. ser. 2, vii. 317 (1841). C. Californica Elmer, Bot. Gaz. xxxix. 48 (1905). Herbage sparsely hirsute and greenish to villous-canescent: leaves oblong or spatulate: heads mostly large and solitary or 2 or 3 together at the ends of cymose branchlets, closely subtended by 1 to several foliose bracts: outer pappus present, squamellate, often concealed by the densely villous hairs clothing the achene.Mendocino Co. to San Diego and Arizona, ace. to Gray; Santa Monica, Davidson, ace. to Abrams; San Bernardino, Parish, no. 570 ; Gaviota, Santa Barbara Co., Elmer, no. 4148 (type of $C$. Californica, outer pappus of disk-flowers present, consisting of many linear toothed paleæ about $.7 \mathrm{~mm}$. long.)

2. C. Wrightii Gray, Syn. Fl. i. pt 2, 446 (1886).

Herbage pubescent with fine soft hairs: leaves probably ovate to lanceolate and 2 to $5 \mathrm{~cm}$. long: involucral bracts all partly herbaceous and the inner ones nearly equalling the flowers: heads discoid: corolla-limb slightly hairy outside: style-appendages subulate-linear, several times longer than the stigmatic portion, which is not much longer than broad: outer pappus obscure; inner pappus extremely copious.

San Bernardino Mts., at 3,500 m. alt. (11,400 ft., and therefore on Mt. Grayback, since no other is so high), Jul., 1882, Wright, ace. to Gray; apparently not since collected. In the absence of specimens the description is taken from the original diagnosis. 


\section{SOLIDAGO L. GOLDENROD.}

Perennial herbs with alternate leaves. Heads small, the raceme-like clusters aggregated into a pyramidal or spike-like panicle, or in one of our species the heads cymose. Bracts of the involucre narrow, thin or chartaceous, mostly destitute of herbaceous tips, imbricated in two or more series. Rays short, yellow, as also are the disk-flowers. Pappus-bristles slender, numerous, in one or two series, equal and dull white in our species. Achenes terete, 5 to 12 -nerved.

Heads in paniculate racemes: rays fewer in number than the disk-flowers.

Herbage very smooth, glabrous.

Involucre 5 or $6 \mathrm{~mm}$. high: lower leaves broadly spatulate or obovate 1. S. spathuluta.

Involucre 3 or $4 \mathrm{~mm}$. high: leaves lanceolate or oblong

2. S. confinis.

Herbage rough or einereous-pubescent. 3. S. Californica. Heads more or less distinctly cymose: rays minute, more numerous than the disk-flowers: herbage glabrous. 4. S. occidentalis.

1. S. spathulata DC., Prodr. v. 339 (1836). S. limonifolia Nutt., Trans. Am. Philos. Soc. ser. 2, vii. 328 (1841)? Cosst GoldDENRoD.

Three to $6 \mathrm{dm}$. high : stems several from the strong root, decumbent or erect, clothed below with broad leaf-bases, simple up to the narrow compact often spike-like thyrsus: herbage glabrous, slightly glutinous: leaves mostly basal, spatulate, rounded at apex, narrowed to a margined petiole; lower ones 5 to $12 \mathrm{~cm}$. long by 2 or $3 \mathrm{~cm}$. broad, serrate above the middle: involucre 5 or $6 \mathrm{~mm}$. high and about as broad, its bracts linearoblong to oblong: rays about 7 or 8 , short and inconspicuous; disk-flowers twice as many: achenes silky-pubescent.

Near Santa Barbara, "between Hatch's wharf and Monticello," 1888, Mrs. Brandegee; common near the coast from middle California to Humboldt Bay.

2. S. confinis Gray, Proc. Am. Acad. xvii. 191 (1882).

Stems simple and leafy up to the terminal panicle: herbage pale green, completely glabrous or rarely with a sparse minute pubescence above: leaves narrowly lanceolate, acuminate but not 
cuspidate, narrowed to the sessile base; the radical ones petioled, rather thin; the middle cauline 8 to $16 \mathrm{~cm}$. long by .5 to $1 \mathrm{~cm}$. broad, either all entire or the lower obscurely serrate: panicle dense, oblong, or sometimes more compound and pyramidal, the heads not secund: involucre 3 or $4 \mathrm{~mm}$. high, its bracts scabrousciliolate or entire: rays scarcely surpassing the disk: achenes minutely to canescently pubescent.

In moist places from Lower California to Los Angeles : Jamul Valley, San Diego Co., Palmer, no. 136; San Bernardino Mts. at 2200 m. alt., Geo. R. Hall, no. 4; San Bernardino Valley at 300 to 450 m. alt., Parish, nos. 4197, 5887; Oak Knoll, near Los Angeles, Braunton, no. 658 ; etc. The altitudinal range covered by this species without undergoing a change in its characters is remarkable, even for a Solidago. The common form of the San Bernardino Valley, in the Upper Sonoran Zone, is exactly reproduced at many places in the neighboring mountains, even to 2300 m. altitude at the upper edge of the Transition Zone.

f. luxurians Hall, form. nov. More robust and the herbage succulent: leaves thickish, broadly lanceolate or oblong, the middle cauline often $15 \mathrm{~cm}$. long by 2 or 2.5 broad: inflorescence oblong or pyramidal, 1 to $3 \mathrm{dm}$. long: heads larger, the involucre about $4 \mathrm{~mm}$. high.-Swampy ground, often in alkaline soil in the vicinity of hot springs, and therefore an ecologic form: Arrowhead Hot Springs, near San Bernardino, altitude 600 m., Parish, no. 1101; same locality, Nov. 1, 1890, Parish; same locality, Sept., 1903, Dr. R. J. Smith; vicinity of San Bernardino, altitude 300 to 450 m., Parish, no. 3809 ; Ventura, Mar., 1861, Brewer, no. 247. Both this and the typical form were probably considered by Dr. Gray while drawing up his original description of $S$. confinis; they certainly were considered while preparing the Synoptical Flora, since not only does the description include them both, but mention is made of Parish's material from the hot springs, as well as of Palmer's San Diego Co. collection. Dr. Robinson informs me that it was G. R. Vasey's specimen from San Diego Co. that Dr. Gray himself marked $S$. confin:s, n. sp. I have not seen Vasey's plant.

3. S. Californica Nutt., Trans. Am. Philos. Soc. Str. 2, vii. 328 (1841). Common Goldenrod. 
Stemis rigid, simple below the terminal panicle, the whole plant 6 to $12 \mathrm{dm}$. high or in the mountains sometimes only 1.5 $\mathrm{dm}$ : herbage green and scabrous or grayish with a minute rough pubescence : leaves oblong, acute at apex, tapering below to a narrow base or short petiole; the lower varying to oblong-obovate and serrate, obtuse, sometimes $1 \mathrm{dm}$. long; the upper smaller, narrow and entire: panicle usually compact and 5 to $20 \mathrm{~cm}$. long, composed of raceme-like clusters (reduced to a simple raceme in dwarf plants, the branches numerous, elongated, and somewhat secund in well developed forms): involucre $4 \mathrm{~mm}$. high; its bracts oblong-linear or lanceolate, rather obtuse, somewhat pubescent: rays 7 to 12 , light yellow, $2 \mathrm{~mm}$. long: disk-flowers rather more numerous: achenes pubescent.

In dry open places, from the lower foothills to $3000 \mathrm{~m}$. altitude in the mountains; Mexico to Oregon and Nevada. In the Sonoran Zone the plants are commonly grayish with a close pubescence (the typical form, first gathered at Santa Barbara by Nuttall); at high altitudes they are green and sparsely seabrouspubescent, sometimes dwarf and the inflorescence either simply racemose (Bluff Lake, 2250 m. alt., Grinnell, no. 86) or branching below (Bluff Lake, Grinnell, no. 95). Normally flowering from Aug. to Dec., but Mr. Parish notes a vernal-flowering form, not otherwise distinguishable, that grows around springs in Reche Cañon, near San Bernardino.

4. S. occidentalis (Nutt.) T. \& G., Fl. ii. 226 (1842). Euthamia occidentalis, Nutt., Trans. Am. Philos. Soc. ser. 2, vii. 326 (1841). Western Goldenrod.

Stems from ereeping rootstocks, very leafy, freely and paniculately branching above, the branches terminated by cymose clusters of small heads (whole plant 1 or $2 \mathrm{~m}$. high): herbage green, glabrous: leaves linear, entire but with faintly scabrous margins, acute, 5 to $10 \mathrm{~cm}$. long and 3 to $10 \mathrm{~mm}$. broad except the small upper ones, sprinkled with pellucid dots: involucre 4 or $5 \mathrm{~mm}$. high; its bracts lanceolate, acute, obscurely pubescent: receptacle with erose or laciniate scales or bristles among the disk-flowers: rays 16 to 20 ; disk-flowers 8 to 14 : achenes turbinate, villous-pubescent.

Common along streams, in wet meadow-land, etc., at lower altitudes throughout our district and northward. Aug.-Nov. 


\section{STENOTUS Nutt.}

Suffruticose or shrubby evergreen plants with narrow entire leaves. Herbage glabrous, resinous-punctate. Heads large and broad, terminating the branchlets. Involucre hemispheric, its bracts little imbricated (in 2 or 3 series), membranous, with scarious margins. Flowers yellow; rays several to many; diskflowers numerous. Achenes oblong, somewhat compressed, densely villous. Pappus of slender bristles, permanently white.

1. S. linearifolius (DC.) T. \& G., Fl. ii. 238 (1842). Haplopappus linearifolius DC., Prodr. v. 347 (1836).

Shrub 6 to $15 \mathrm{dm}$. high (sometimes depauperate), with resinous herbage and stout woody branches: branchlets more or less fastigiate, leafy below, terminating in simple nearly naked peduncles: leaves much crowded, linear, acute, narrowed toward the base, 2 to $4 \mathrm{~cm}$. long, 1 to $2 \mathrm{~mm}$. wide: involucre 10 to 13 $\mathrm{mm}$. high; its bracts oblong, acuminate, greenish, the inner ones with broad scarious fimbriolate margins: rays 13 to 18 , oblonglanceolate, 1 to $2 \mathrm{~cm}$. long: achenes white-silky: pappus white, soft, deciduous.

Zapato Chino, Lower California, Brandegee; common at a few places along the cismontane (western) base of the San Jacinto and San Bernardino Mts. at about 900 m. alt.; reappearing on Mono Creek, Santa Barbara Co., where rare; again common in the Mt. Diablo Range of middle California; to be looked for at intermediate stations.

Var. interior (Coville) Hall, comb. nov. Haplopappus interior Coville, Proc. Biol. Soc. Wash. vii. 65 (1892). H. linearifolius interior, M. E. Jones, Proc. Calif. Acad. ser. 2, v. 697 (1895). Leaves shorter, commonly 1 or $2 \mathrm{~cm}$. long: bracts of the peduncle commonly linear-subulate: heads not so large, the rays .5 to $1 \mathrm{~cm}$. long: involuere 8 to $10 \mathrm{~mm}$. high, its bracts sometimes only acute.-A form inhabiting arid places, especially within the Desert Area: Darwin Mesa, Inyo Co., Coville \& Funston, no. 794 (duplicate-type of A. interior) ; Providence Mits., Brandegee; eastern slope of Greenhorn Mts., Kern Co. Hall \& Babcock, no. 5088; Mt. Pinos, Ventura Co., Hall, no. 6498; common in Antelope Valley from Mohave, ete., to north slope Cajon 
Pass; Kenworthy, San Jacinto Mts.; Coyote Cañon; San Felipe and Witch Creek, San Diego Co.; San Pedro Martir, Lower California, Brandegee; Arizona to Utah. Along the western limits of its range the variety passes directly into the species, and certain specimens from Mt. Diablo, which is presumably near the type locality of $S$. linearifolius, have the short leaves and small heads of the variety, these characters apparently varying from year to year with climatic conditions. The bracts of the peduncle are often subulate in otherwise typical linearifolius, and the involucral bracts are seldom less than acuminate in the variety.

\section{HAPLOPAPPUS Cass.}

Annual or perennial herbs or low shrubs. Heads mostly rather large, hemispheric, in terminal cymose or paniculate clusters or solitary, rarely sessile. Involucre imbricated, its bracts mostly with green or herbaceous tips. Rays present, yellow. Disk-flowers permanently yellow. Style-branches various. Achenes of the ray usually fertile, both these and the disk-achenes slightly or not at all compressed. Pappus of numerous unequal dull-white or reddish bristles.

Herbage loosely tomentose: Transition Zone species 1. H. gossypinus. Herbage glabrous or eanescent: Sonoran species.

Annual: stems leafy. 2. H. gracilis.

Perennial: stems reedy, leaves reduced 3. H. junceus.

1. H. gossypinus (Greene) Hall, comb. nov. Pyrrocoma yossypina Greene, Pitt. iii. 23 (1896).

Stems several, from a thick often fusiform perennial caudex, decumbent or erect, 1.5 to $2 \mathrm{dm}$. high: herbage tomentose when young, the tomentum decidnous except from the axils of the lower leaves: basal leaves numerous, oblanceolate or linearoblanceolate, entire or serrate, acute, 2 to $12 \mathrm{~cm}$. long including the petiole; cauline leaves narrow, $3 \mathrm{~cm}$. or less long, entire: heads racemose or solitary terminating the simple stems: involucre hemispheric, 10 to $12 \mathrm{~mm}$. high, loosely imbricated; bracts linear-acuminate, without distinct green tips: rays about 20, clear yellow, $7 \mathrm{~mm}$. long: achenes (nearly mature) oblong, very canescent. 
Bear Valley, in the Transition Zone of the San Bernardino Mts., apparently very local : Parish, Aug. 1882, no. 1558; Abrams, Aug., 1902, no. 2917. A segregate from H. lanceolatus (Hook.) T. \& G., distinguished by its slender involucral bracts destitute of green tips and by its loose cottony pubescence.

H. APARGIOIDES has the general appearance of $H$. gossypinus, but the leaves are laciniate and the linear achenes are glabrous or nearly so. Acc. to $\mathrm{Gray}^{7}$, it was collected in the San Bernardino Mts. by Parry, but there is probably an error in the label, since diligent search has failed to rediscover the species south of T'ulare Co.

2. H. gracilis (Nutt.) Gray, Pl. Fendl. 76 (1849). Dieteria gracilis Nutt., Journ. Phila. Acad. n. ser. i. 177 (1848). Eriocarpum gracile Greene, Eryth. ii. 109 (1894).

Plant annual, erect, a few $\mathrm{cm}$. to $2 \mathrm{dm}$. high; the solitary stem simple or branched: herbage canescent, rarely glabrate or scabrous: principal leaves oblanceolate or narrower, 1 to $3 \mathrm{~cm}$. long, pinnatifid, each lobe ending in a slender bristle; upper leaves linear, entire or only toothed, bristle-tipped: involucre broadly hemispheric, 6 or $7 \mathrm{~mm}$. high, imbricated; bracts linear, tapering above into a bristle: rays 20 to 25 , yellow, nearly $1 \mathrm{~cm}$. long: achenes canescent: pappus sordid or yellowish, of numerous rigid bristles thickened at base, the longer ones equalling the corollas.

Providence Mts., eastern part of the Mohave Desert, Jun. 6, 1902, Brandegee; Lower California, Arizona, Utah, ete.

H. SPINulosus (Pursh.) DC. ranges from the Saskatchewan to Lower California and may be expected in our district. It is a perennial with broader leaves than $H$. gracilis.

3. H. junceus Greene, Bull. Calif. Acad. i. 190 (1885). Eriocarpum junceum Greene, Eryth. ii. 108 (1894).

Commonly 5 to $10 \mathrm{dm}$. high, the slender wiry stems tufted from a woody base and sparsely leafy: herbage nearly or quite glabrous, the involucres viseid and scabrous: leaves .5 to $2 \mathrm{~cm}$. long, linear, pinnatifid and the lobes spinulose-tipped, or the upper ones entire and tipped with a white mucro: involucre

\footnotetext{
7 Bot. Calif. ii. 464 (1880).
} 
finally hemispheric, $8 \mathrm{~mm}$. high, its well imbricated green bracts ending in a rigid setaceous tip : rays pale yellow: achenes pubescent, slightly flattened, either with or without a strong nerve on each face.

Southwestern San Diego Co. and southward into Lower California.

\section{ERICAMERIA Nutt.}

Evergreen shrubs, with linear or terete leaves except in our first species. Foliage commonly punctuate and resiniferous. Inflorescence various but usually paniculate or cymose. Heads either heterogamous or homogamous, even on the same plant. Involucre narrowly to broadly turbinate (hemispheric in vernal heads of E. pinifolia) the chartaceous or coriaceous bracts rigidly imbricated but not in distinct vertical rows, the outer ones passing into small bracts of the peduncle. Ray-flowers either present or lacking; disk-corollas ampliate upward, 5-toothed. Style-appendages exserted (scarcely so in some species), filiform or subulate in all but E. monactis. Achenes slender. Pappusbristles slender, scabrous, dull white or yellowish, in age reddish.

The genus as here defined corresponds to Haplopappus \& Ericameria of Gray's Synoptical Flora, so amplified as to include Bigelovia \& Euthamiopsis of the same work. Its small narrow involucres with chartaceous bracts are the only marks to distinguish it from Haplopappus; but to one familiar with its species it forms a definite group. The style-appendages are always slender and exserted except in E. monactis, which also in other respects connects Ericameria to Haplopappus. It would be easy to follow Greene in extending Ericameria (which he would now merge into Chrysoma) to include certain species of Chrysothamnus which have a similar general aspect (C. teretifolius, paniculatus, etc.). These, however, are apparently not derived from the same immediate stock and may well remain in Chrysothamnus, mainly because of their narrow involucres with bracts in distinct vertical series.

Leaves obovate or oblanceolate, spatulate: var. spatulata of

1. E. cuneata.

Leaves linear or filiform (or lanceolate in no. 6).

Style-appendages oblong-ovate, acute: involucral bracts 8 to 10 : rays 1 or 2 or wanting.

2. E. monactis. 
Style-appendages filiform-subulate: involucral bracts more numerous.

Rays present.

Outer bracts of the involucre obtuse: achenes appressed-pubescent 3. E. Palmeri.

Outer bracts of the involucre acuminate: achenes lightly pubescent, glabrate: leaves mostly over $1 \mathrm{~cm}$. long....4. E. pinifolia.

Outer bracts of the involucre acute: achenes glabrous: leaves mostly .5 to $1 \mathrm{~cm}$. long.

5. $E$. ericoides.

Rays wanting.

Heads in close rounded terminal cymes.

Leaves flat, broadly linear to lanceolate (3 to $10 \mathrm{~mm}$. wide) 6. E. Parishii.

Leaves filiform or very narrowly linear (2 mm. or less wide)

7. E. arborescens.

Heads in loose oblong panicles or racemes: leaves filiform.

Leaves $12 \mathrm{~mm}$. or less long: heads 6 to 8 -flowered

8. E. Cooperi.

Leaves 12 to $24 \mathrm{~mm}$. long: heads 8 to 12 -flowered

9. E. brachylepis.

1. E. cuneata spathulata (Gray) Hall, comb. nov. Bigelovia spathulata Gray, Proc. Am. Acad. xi. 74 (1876). B. rupestris Greene, Bot. Gaz. vi. 183 (1881). Chrysoma cuneata spathulata Greene, Eryth. iii. 11 (1895). C. Merriami Eastw., Bull. Torr. Club xxxii. 214 (1905).

Plant spreading, woody at base, 1 to $3 \mathrm{dm}$. high, freely branching: herbage glabrous but resinous-punctate: leaves thick, entire or merely undulate-margined, obovate to oblanceolate, spatulate at base, obtuse, often retuse and usually mucronate at summit, 6 to $15 \mathrm{~mm}$. long, 3 to $10 \mathrm{~mm}$. broad: heads in small compact cymes or sometimes solitary: involucre turbinate, 6 to $8 \mathrm{~mm}$. high; bracts lanceolate to linear, chartaceous, marked with a brown or greenish medial line and bordered with a silvery-scarious margin, somewhat obtuse but usually cuspidate-tipped, the outermost passing into minute bracts of the peduncle: rays (always?) lacking: achenes densely silky-pubescent with appressed hairs: pappus-bristles copious, about equal and as long as the corolla, brown.

Most plentiful on rocky ledges of mountains on or near the desert, extending into Lower California; but also found on the 
coastal slope of the San Gabriel and San Bernardino Mts. at a few stations. The var. differs from $E$. cuneata in its more compact habit, broader leaves, and absence of rays.

2. E. monactis (Gray) MeClatehie, Eryth. ii. 124 (1894). Haplopappus monactis Gray, Proc. Am. Acad. xix. 1 (1883). Acamptopappus microcephalus Jones, Contr. W. Bot. viii. 33 (1898). T'umionella monactis Greene, Leaflets, i. 173 (1906). Chrysothamnus corymbosus Elmer, Bot. Gaz. xxxix. 50 (1905).

Shrub, 4 to $10 \mathrm{dm}$. high, the numerous branchlets leafy: herbage minutely pubescent on all but the older parts, the foliage sometimes resinous-punctate: principal leaves flat, linear, acute, .5 to $2 \mathrm{~cm}$. long, especially the lower commonly with minute fascicled ones in their axils: inflorescence cymose; the cymes roundtopped, terminating the branchlets: involucre narrowly campanulate, 4 or $5 \mathrm{~mm}$. high; bracts loosely imbricated, chartaceous with dull-green midrib, rather obtuse but the small outer ones often acute: rays one or two or entirely lacking in some heads, occasional plants with all the heads discoid: disk-flowers 5 to 8 : style-appendages flat, ovate or narrower, acute: achenes whitevillous.

Upper portion of the Lower Sonoran Zone: Mohave Desert from the Providence Mts. on the east to Tejon Pass on the west, north to Owens Valley and south through Cajon Pass as far as West Riverside; also in Rubio Cañon, back of Los Angeles, ace. to MeClatehie. ${ }^{8}$ Most plentiful from the Mohave River westward through Antelope Valley. Apr.-Jun. Perhaps not distinct from E. laricifolia of Arizona, etc., but that has narrower more acute bracts and more slender style-appendages.

3. E. Palmeri (Gray) Hall, comb. nov. Haplopappus Palmeri Gray, Proc. Am. Acad. xi. 74 (1876). Chrysoma Palmeri Greene, Eryth. iii. 12 (1895).

Low shrub, usually 3 to $6 \mathrm{dm}$. high, much branched and of bushy habit: growing parts minutely puberulent: principal leaves narrowly linear, 1 to 2 (or 4 ) $\mathrm{cm}$. long, mostly with shorter ones fascicled in their axils, resinous and punctate: inflorescence an elongated panicle: involucre narrow, 6 or $7 \mathrm{~mm}$.

8 Eryth. ii. 124 (1894). 
high; bracts obtuse, the tips greenish, the narrow white margins shortly eiliate: rays several, short: achenes silky-pubescent.

Very common in the foothills and on the plains west of the mountains extending south into Lower California and east to the Colorado River.

4. E. pinifolia (Gray) Hall, comb. nov. Haplopappus pinifolius Gray, Proc. Am. Acad. viii. 636 (1873). Chrysoma pinifolia Greene, Eryth. iii. 12 (1895).

Stout spreading shrub 6 to $16 \mathrm{dm}$. high: herbage nearly glabrous, resinous but not noticeably punctate: leaves narrowly linear to filiform, mucronate, $1 \mathrm{~cm}$. or more long, the fascicled ones shorter as also are the numerous crowded ones of the branchlets: vernal heads solitary, hemispheric, about $12 \mathrm{~mm}$. broad, surrounded by long slender acuminate leaves simulating an outer involucre: autumnal heads paniculate or racemose, often congested, less leafy-bracted, turbinate, about $6 \mathrm{~mm}$. broad: involucre of the autumnal heads about $7 \mathrm{~mm}$. high; bracts acuminate or the inner only acute, greenish-tipped, with membranous woolly-ciliolate margins; the outermost passing into small leaves of the flowering branchlets : rays of the vernal heads 20 to 30 , of the autumnal heads 6 to 10, short: pappus sordid: achenes lightly pubescent, glabrate.

Along the foothills from Western Los Angeles Co. (Newhall) to the Cuyamaca and Laguna Mts. of San Diego Co. A common element of the chaparral belt. Solitary heads Apr.-Jun.: paniculate heads Aug.-Nov.

5. E. ericoides (Less.) Jepson, Fl. W. Mid. Calif. 559 (1901). Diplopappus ericoides Less., Linnaea, vi. 117 (1831). Haplopappus ericoides H. \& A., Bot. Beech. 146 (1833). Ericameria microphylla Nutt., Trans. Am. Philos. Soc. ser. 2, vii. 319 (1841). Chrysoma ericoides Greene, Eryth. iii. 11 (1895).

Heather-like shrub, 3 to $8 \mathrm{dm}$. high, decidedly shrubby at base, with decumbent or ascending main stems and numerous erect branchlets: herbage resinous, inconspicuously punctate, the growing parts puberulent but green: leaves filiform, .5 to 1 . $\mathrm{cm}$. long, in numerous close fascicles, or the lower ones longer and not fascicled: heads cymose-paniculate; involucre 5 or $6 \mathrm{~mm}$. 
high; bracts oblong or lanceolate, acute, greenish-yellow with dark tips, tomentose-ciliolate: rays several, 4 to $6 \mathrm{~mm}$. long: achenes glabrous: pappus copious, dull white, becoming brown.

Common in the Upper Sonoran Zone along the coast from Los Angeles Co. (and further south?) to beyond San Francisco; San Miguel Island, acc. to Greene, Pitt. i. 89 (1887).

6. E. Parishii (Greene) Hall, comb. nov. Bigelovia Parishii Greene, Bull. Torr. Club ix. 62 (1882). Chrysoma Parishii Greene, Eryth. iii. 10 (1895).

Arborescent shrub, 2 to $5 \mathrm{dm}$. high: branchlets very leafy up to the inflorescence: herbage resinous-punctate: leaves "lanceolate" or linear, entire, narrowed at base, acute, traversed by 3 nerves, only the medial of which is prominent, 2 to $6 \mathrm{~cm}$. long, 3 to $10 \mathrm{~mm}$. wide: bracts of the inflorescence linear-subulate: heads discoid, in terminal rounded cymes, 10 to 12 -flowered: involucre $5 \mathrm{~mm}$. high : its bracts lanceolate, very acute, with a distinct green or brownish midrib, no green tip: achenes turbinate, minutely silky.

Upper Sonoran Zone, nowhere common: south slope of San Gabriel and San Bernardino Mts., east at least to Waterman Cañon, the type locality; Santa Ana Mts.; Cuyamaca Mts.; San Pedro Martir, Lower California (Robertson, no. 48).

7. E. arborescens (Gray) Greene, Man. Bot. Reg. S. F. Bay. 175 (1894). Linosyris arborescens Gray, Bot. Mex. Bound. 79 (1859). Chrysoma arborescens Greene, Eryth. iii. 10 (1895).

Stem erect, with fastigiate branches, the whole shrub, 1 to 2 m. high: branchlets leafy: herbage resinous-punctate: leaves narrowly linear or closely revolute and thus becoming filiform, 3 to $6 \mathrm{~cm}$. long, $2 \mathrm{~mm}$. or less wide: heads in terminal rounded cymes, 20 to 25 -flowered: involucre $5 \mathrm{~mm}$. high or rather less; its bracts lanceolate, acute, traversed by a brown midrib: rays none ("seldom present," acc. to Greene ${ }^{9}$ ): achenes canescent.

Upper Sonoran Zone: Santa Barbara, Mrs. Bingham; Santa Lucia Mts.; northward in the Coast Ranges. Also sparingly in the Sierra Nevadas. Sept.-Nov.

\footnotetext{
${ }^{9}$ Man. Bot. Reg. S. F. Bay, 175 (1894).
} 
8. E. Cooperi (Gray) Hall, comb. nov. Bigelovia Cooperi Gray, Proc. Am. Acad. viii. 640 (1873). Chrysoma Cooperi Greene, Eryth. iii. 12 (1895).

Stems slender, probably less than $1 \mathrm{~m}$. high : herbage minutely tomentose, resinous: leaves filiform (or narrowly linear?), acute, $2 \mathrm{~cm}$. or less long: inflorescence paniculate: heads 6 to 8 flowered; rays none: involucral bracts narrowly oblong (the inner ones lanceolate, attenuate, 7 or $8 \mathrm{~mm}$. long; outer ones ovate, obtuse?), chartaceous, pale to the apex: style-appendages ovate-subulate.

Known only from the Providence Mts. in the Mohave Desert of eastern San Bernardino Co. First found by Cooper, ace. to Gray; rediscovered by Brandegee, if certain specimens gathered by him Jun. 6, 1902 with only vestiges of the previous years' heads belong to this species.

9. E. brachylepis (Gray) Hall, comb. nov. Bigelovia brachylepis Gray, Bot. Calif. i. 614 (1876). Chrysoma brachylepis Greene, Eryth. iii. 12 (1895).

Shrubs 1 to $2 \mathrm{~m}$. high, branched from the base: leaves of the branches crowded, viscid and resinous-punctate, glabrous, filiform or slightly flattened, 1 or $2 \mathrm{~cm}$. long: heads racemose among the upper leaves or narrowly paniculate: involucre 4 to $6 \mathrm{~mm}$. high; bracts oblong, obtuse or only acutish, with a brown resinousthickened medial line and ciliate margins, outermost passing into minute bracts of the peduncle: heads 8 to 12 -flowered; rays none: style-appendages subulate-filiform: achenes linear, canescent.

Southwestern San Diego Co.: Larkins Station, Palmer, ace. to Gray; Potrero, Cleveland; Campo, Orcutt. Also at El Rosario, Lower California, Brandegee.

\section{CHRYSOTHAMNUS Nutt.}

West American shrubby or suffrutescent plants with hard wood and narrow or terete entire leaves. Herbage white-tomentose or glabrous, often viscidulous or resinous. Inflorescence paniculate, cymose, or rarely racemose. Heads homogamous. Involucre narrow; its bracts well imbricated usually in more or 
less distinct vertical ranks, chartaceous or coriaceous, mostly destitute of herbaceous tips. Ray-flowers uniformly lacking; diskflowers 5 to 30. Style-branches subulate or filiform, in all our species long-exserted. Achenes narrow, terete or slightly angled, pubescent. Pappus copious, soft, commonly dull white or reddish.

Chrysothamnus is connected by our first two species with Ericameria; by our last species with Haplopappus ( $\$$ Macronema). From Bigelovia (Chondrophora, Chrysocoma nudata) it differs in habit and geographic distribution, that being a perennial herb of the Atlantic seaboard, extending west to Texas. Bigelovia has, moreover, shorter and thicker style-appendages, short somewhat turbinate and nearly or quite glabrous achenes, and a rigidulous pappus. ${ }^{10}$

Branches glabrous.

Herbage resinous-punctate: leaves terete.

Outer involucral bracts with a distinct greenish subapical spot

... C. teretifolius.

Involucral bracts pale, wholly nakeci

2. C. paniculatus.

Herbage not resinous-punctate: leaves narrow but plane or canaliculate.

Stems leafy: involucre 5 to $8 \mathrm{~mm}$. hig's.

3. C. viscidiflorus.

Stems nearly leafless: involucre about $1 \mathrm{~cm}$. high: glabrate state of ..4. C. Mohavensis.

Branches clothed with a dense white tomentum.

Leaves sparse: involucral bracts obtuse, the vertical ranks very distinct ..4. C. Mohavensis.

Leaves numerous.

Heads 5-flowered.

Involucral bracts abruptly contracted to a spreading setiform tip or short awn.

5. C. ceruminosus.

Involucral bracts not abruptly tippe

6. C. nauseosus.

Heads about 9-flowered: involucral bracts acuminate, a few of the outer ones foliaceous

7. C. Parryi.

1. C. teretifolius (Dur. \& Hilg.) Hall, comb. nov. Linosyris teretifolia Dur. \& Hilg., Pacif. R. Rept. v. 9, pt. 3, t. 7. (1856). Bigelovia teretifolia Gray, Proc. Am. Acad. viii. 644 (1873). Chrysoma teretifolia Greene, Eryth. iii. 12 (1895).

10 Cf. Greene, Eryth. iii. 91, 92 (1895). 
Plant woody at base, with rigid fastigiate very leafy branches and small heads in terminal cymes or panicles: herbage glabrous but resinous-punctate, becoming balsamic-viscid: leaves thick, terete, deep green, .7 to $2 \mathrm{~cm}$. long: involucre narrow, $6 \mathrm{~mm}$. high: bracts obtuse, earinate, the outer successively shorter and bearing near the apex a distinct green or brownish glandular thickening: achenes linear, silky-pubescent.

Arid plains and hills of the Desert Area, east into Nevada and Arizona: mountains around Tejon Valley, Heermann, acc. to Gray; Antelope Valley, Pringle, ace. to Parish; Inyo Co., Austin, no. 414, also Purpus, no. 3060; Whitewater and Palm Springs, Colorado Desert, acc. to Parish; Cuyamaca Mts., Palmer, ace. to Gray; east to Arizona (?) and Nevada. Aug.-Oct.

2. C. paniculatus (Gray) Hall, comb. nov. Bigelovia paniculata Gray, Proc. Am. Acad. viii. 644 (1873). Chrysoma paniculata Greene, Eryth. iii. 12 (1895).

Much like no. 1 but more slender in all its parts and the foliage and involucres paler : plant $2 \mathrm{~m}$. or less high : inflorescence a profusely branched panicle: involucral bracts straw-color, thin, obtuse, destitute of the subapical glandular spot, the inner ones 6 or $7 \mathrm{~mm}$. long.

Lower Sonoran Zone, on both the Colorado and Mohave deserts, east into Arizona: near Cabazon, Schellenger, no. 43, also Parish, no. 655; Chuckawalla Bench, Schellenger, no. 19; near Bagdad, Brandegee. On gravelly plains between Cabazon and Whitewater it grows to a height of $2 \mathrm{~m}$. or more (6 to $8 \mathrm{ft}$.) ace. to Parish. Oct.-Nov.

3. C. viscidiflorus (Hook.) Nutt., Trans. Am. Philos. Soc. ser. 2, vii. 323 (1841). Crinitaria viscidiflora Hook., Fl. Bor. Am. ii. 24 (1834). Bigelovia Douglasii Gray, Proc. Am. Acad. vii. 645 (1873).

Branching shrub, $1 \mathrm{dm}$. to $2 \mathrm{~m}$. or more high: stems with a grayish fibrous bark, the twigs smooth and commonly white: herbage destitute of all tomentum, smooth and glabrous or merely scabrid: leaves narrow, acute, mostly 3-nerved: inflorescence cymose: involucre 5 to $8 \mathrm{~mm}$. high; bracts only 3 or 4 in each vertical rank (these ranks therefore indistinct), oblong or lanceol- 
ate, obtuse, chartaceous, sometimes with an indistinctly greenish thickened tip: style-appendages thickish, shorter than the stigmatic portion.-A polymorphous species, of which only the following varieties reach our district:

Var. tortifolius (Gray) Hall, eomb. nov. Bigelovia Douglasii tortifolia Gray, Proc. Am. Acad. viii. 646 (1873). Leaves linear or narrowly lanceolate, acute, mostly 2 to $4 \mathrm{~cm}$. long, more or less twisted, the margins serrulate-ciliolate.-Mt. Pinos, Ventura Co., common on the summit; Tejon Pass; Bear Valley, San Bernardino Mts.; "San Jacinto Mt.," Nevin; more plentiful in the Sierra Nevadas and eastward. Aug.-Oct.

Var. stenophyllus (Gray) Hall, comb. nov. Bigelovia Douglasii stenophylla Gray, Proc. Am. Acad. viii. 646 (1873). Leaves $2 \mathrm{~mm}$. or less wide, mostly 2 to $4 \mathrm{~cm}$. long, not twisted, the margins serrulate-ciliolate or smooth.--S.E. California, acc. to Gray; near Acton, Los Angeles Co., Hasse, acc. to Parish. The Bear Valley specimens mentioned under var. tortifolia might be considered as belonging here, the leaves being very narrow and only some of them twisted.

4. C. Mohavensis Greene, Eryth. iii. 113 (1895). Bigelovia Mohavensis Greene, in Gray, Syn. Fl. i. pt. 2, 138 (1884).

About $1 \mathrm{~m}$. high; the loose branches erect or ascending, yellowish-green and nearly destitute of foliage: herbage canescent with a fine pannose tomentum when young, glabrate and somewhat viscid in age: leaves few, ascending or appressed, linear, $5 \mathrm{~cm}$. or less long: heads in narrow terminal panicles: involucre cylindric-turbinate, $10 \mathrm{~mm}$. high, $5 \mathrm{~mm}$. broad at summit; its bracts about 5 in each of the 5 conspicuous vertical ranks, obtuse and short-muticous, the midnerve thickened and brown, especially above: achenes appressed-villous.

Mohave Desert; apparently rare.

5. C. ceruminosus (Dur. \& Hilg.) Greene, Eryth. iii. 94 (1895). Linosyris ceruminosa Dur. \& Hilg., Pacif. R. Rept. v. pt. 3, 9, t. 6 (1856). Bigelovia ceruminosa Gray, Proc. Am. Acad. viii. 643 (1873).

Shrub erect, 6 to $9 \mathrm{dm}$. high, fastigiately branched: herbage densely tomentose, resinous: leaves linear or nearly filiform, 
about $2.5 \mathrm{~cm}$. long on the stems, less than half as long and recurving on the branches, puberulent: heads cymose-fascicled, crowded: bracts of the viscidly lucid involucre narrowly lanceolate, abruptly produced into a spreading setiform tip or short awn, or the much shorter outermost ones muticous.

Collected only by Dr. Heermann; somewhere near Tejon Pass. In the absence of specimens the above description is as given by Gray.

6. C. nauseosus (Pall.) Britton, in Britt. \& Br., Ill. Fl. iii. 326 (1898). Chrysocoma nauseosa Pall., in Pursh, Fl. ii. 517 (1814). Bigelovia graveolens albicaulis Gray, Proc. Am. Acad. viii. 645 (1873).

Low shrub with the branches densely and permanently whitetomentose and the leaves loosely white-tomentose in the typical form: leaves oblanceolate to linear (very narrowly linear in the typical form), entire, strongly l-nerved: inflorescence cymose: heads 5 -flowered : involucre 10 or $12 \mathrm{~mm}$. high; bracts lanceolate, acute, keeled by the strong nerve, imbricated in indistinctly vertical ranks: corolla with rather short ovate or lanceolate teeth, the tube arachnoid-pubescent: style-appendages subulate-filiform, longer than the stigmatic portion: pappus soft.

Alberta and Washington, south to Wyoming and Southern California. As here drawn the description includes a rare plant of the San Bernardino Mts. which, while certainly unlike the original form, cannot now be satisfactorily separated: Strawberry Peak, Parish, no. 1868; Bear Valley, 1896, Davidson.

Var. occidentalis (Greene) Hall, comb. nov. C. Californicus occidentalis Greene, Eryth. iii. 112 (1895). C. occidentalis Greene, Fl. Fr. 369 (1897). Bigelovia graveolens glabrata Hall, Univ. Calif. Pub. Botany, i. 125 (1902); not Gray. Plant low and bushy: stems ascending or erect, permanently clothed with a close white tomentum: leaves narrowly linear, acute, 2 to 3 $\mathrm{cm}$. long, less than $2 \mathrm{~mm}$. broad, green and devoid of tomentum: inflorescence tomentulose, at least the peduncles and small outer involucral bracts very minutely glandular: heads in rounded terminal cymes, 5-flowered: involucre narrowly turbinate, 10 or $11 \mathrm{~mm}$. high; bracts about 4 in each vertical rank, thin-chartaceous, lanceolate, acuminate or acute, keeled by the strong mid- 
nerve: eorolla-teeth lanceolate, rather long; throat tapering gradually to the tube which is only minutely and sparsely pubescent: achenes villous: style-branches subulate-filiform, longexserted.-Common in the Transition and Canadian zones, 1800 to $3000 \mathrm{~m}$. alt.: Little Green Valley, San Bernardino Mts., altitude 2200 m., Jul., 1904, George R. Hall, no. 34; Bluff Lake, San Bernardino Mts., Grinnell, no. 94; Barton Flats, San Bernardino Mts., Mrs. Wilder, no. 597; Round Valley, San Jacinto Mt. (where abundant on hillsides), Hall, no. 341; in Kern and Santa Barbara counties, ace. to Greene. ${ }^{11}$ Jul.-Sept.

Var. graveolens (Nutt.) Piper, Contr. U. S. Nat. Herb. xi. 559 (1906). Chrysocoma graveolens Nutt., Gen. ii. 136 (1818). Bigelovia graveolens Gray, Proc. Am. Acad. viii. 644 (1873). RABBIT-BRUSh. Robust shrub, commonly 1 to $3 \mathrm{~m}$. high : branchlets white-tomentose when young, commonly glabrate and yellowish-green in age: leaves 2 to $5 \mathrm{~cm}$. long, linear or lanceolatelinear to almost filiform, flocculent-tomentose, sometimes glabrate and green in age: involucral bracts oblong to linear-lanceolate, obtuse to acute: corolla-teeth short; tube nearly glabrous.-A common shrub in the arid Upper Sonoran of Western North America : abundant in Owens Valley, Inyo Co., whence it extends southward, but less plentifully, across Antelope Valley to Elizabeth Lake and through Sodedad Cañon to Saugus, Los Angeles Co.; also on sandy plains near Colton, San Bernardino Co., coming perhaps through Cajon Pass. In Owens Valley the Rabbit-brush grows in the Sagebrush belt and completely replaces that shrub if the land is cleared and then allowed to lie fallow. It is here indicative of good soil without excess of alkali, the Rabbit-brush lands being especially suitable for such crops as alfalfa, corn, and potatoes, where irrigation can be practiced. Gray's statement that it grows in "sterile and especially alkaline soil" is therefore misleading, at least in so far as it concerns our California plant.

7. C. Parryi (Gray) Greene, Eryth. iii. 113 (1895). Linosyris Parryi Gray; Proc. Phila. Acad. for 1863, p. 66. Bigelovia Parryi Gray, Proc. Am. Acad. viii. 642 (1873). 
Freely branching leafy shrub, $6 \mathrm{dm}$. or less high: stems densely white-tomentose, the foliage very minutely glandular, the involucres nearly glabrous: leaves linear, acute, 2 to $5 \mathrm{~cm}$. long, 2 or $3 \mathrm{~mm}$. wide, 1-nerved: heads few, in a narrow terminal leafy raceme, about 9-flowered: involucre narrowly campanulate; bracts about 12, loosely imbricated in very indistinct vertical ranks, thin-chartaceous, lanceolate, acuminate, the principal ones 11 or $12 \mathrm{~mm}$. long, several of the outermost ones with elongated green tips overtopping the proper involucre and resembling the uppermost leaves: throat and teeth of the corolla sparsely arachnoid-pubescent: style-branches filiform, long-exserted: achenes sericeous-pubescent.

Mainly of the Rocky Mts., but this description from specimens gathered at $2100 \mathrm{~m}$. altitude in the arid Transition Zone of Alamo Mt., eastern Ventura Co. (Hall, no. 6701).

\section{ISOCOMA Nutt.}

Somewhat woody plants with elongated rigid stems and thickish closely sessile leaves. Herbage never resinous-punctate. Heads rayless, collected into glomerules which are either terminal on short lateral branchlets or disposed in a terminal cymose cluster. Involucral bracts coriaceous, closely imbricated, the tips herbaceous but appressed. Flowers permanently yellow. Corollatube slender, the throat ventricose or obliquely dilated, its segments erect or more or less connivent about the style. Styleappendages subulate-lanceolate or broader. Achenes longitudinally striate or ribbed, silky-pubescent or hirsute. Pappus of numerous sordid bristles, the innermost longest and often distinctly flattened.

1. I. veneta vernonioides (Nutt.) Jepson, Fl. W. Mid. Calif. 560 (1901). I. vernonioides Nutt., Trans. Am. Philos. Soc. ser. 2, vii. 320 (1841). Bigelovia Menziesii Gray, Proc. Am. Acad. viii. 638 (1873). Isocoma microdonta, latifolia, villosa, sedoides, \& decumbens Greene, Leaflets i. 171-2 (1906).

Plant 4 to $12 \mathrm{dm}$. high, half-woody at the branched base above which the stems are commonly simple up to the cymose or paniculate inflorescence: herbage from minutely scabrous to 
villous-arachnoid, rarely glabrous; leaves oblanceolate, spatulate, or euneate-oblong, 1 to $3 \mathrm{~cm}$. long or the lower twice this length and the numerous fascicled ones much shorter, acutely toothed or the upper narrow ones often entire: involucre narrowly to broadly turbinate, 7 or $8 \mathrm{~mm}$. high, 15 to 35 -flowered; its bracts with distinct green tips, commonly granulose on the back and with ciliate or erose white margins, varying from obtuse to acute and cuspidate in the same head, sometimes bearing an indistinct resinous gland: achenes linear-turbinate.

Common in the Upper Sonoran Zone west of the mountains throughout Southern California. Quite variable in foliage, inflorescence, and involucre: when the branches are very leafy, villous-arachnoid, and branched above, it is I. villosa Greene (Santa Monica, Hall, no. 3276, etc.). When this form has a more compactly cymose infloreseence, obtusish bracts, and short broad leaves, it is I. latifolia Greene (Santa Cruz and Santa Rosa islands, aec. to Greene; San Miguel Island, Greene; San Luis Obispo, Mrs. Summers, no. 394; etc.). A more marked form is $I$. sedoides Greene, which has prostrate stems, obovate succulent leaves, a nearly glabrous herbage, and crowded heads (Santa Cruz Island, Greene), yet this differs from I. latifolia only in pubescence and habit; and specimens gathered at San Luis Rey, San Diego Co., by Mrs. Brandegee vary from almost exact duplicates of Greene's Santa Cruz specimens (duplicate types!) to good "latifolia." Material from San Clemente Island, Aug. 25, 1894, Brandegee, has the smooth suceulent herbage of sedoides but the leaves are narrow and inflorescence various. All of these are of course mere forms due to varying edaphic conditions, proximity of salt water, winds, ete.

I. decumbens Greene is a slender, decumbent form with narrow, entire or toothed, scattered leaves and pedicellate heads; the type was from clay depressions on the mesas near San Diego, but on nearby hillsides it is replaced by a form exactly its counterpart except that the stems are ereet. When the herbage is scabrous and the inflorescence leafy, we have I. microdonta Greene. Specimens gathered in somewhat saline soil, San Bernardino Co., Oct., 1887, by Parish, although plainly of var. vernonioides, have narrow mostly entire leaves; and other inter- 
mediates connect this variety directly with the next. One of these is I. oxyphylla Greene (near San Diego, Palmer, no. 134), which has thin, narrow, entire, very acute leaves and large, turbinate heads : both involucre and leaves are slightly pubescent in Palmer's no. 134 as represented by a specimen in the Brandegee Herbarium, and the corolla-limb is not "remarkably short" as described by Greene. Mission Valley, near San Diego, 1883, Cleveland, is the same, but with many of the leaves remotely toothed.

Var. acradenia (Greene) Hall, comb. nov. Bigelovia acradenia Greene, Bull. Torr. Club x. 126 (1883). Isocoma acradenia Greene, Eryth. ii. 111 (1894). I. bracteosa, leucanthemifolia, \& eremophila Greene, Leaflets i. 170-171 (1906). Herbage very light-colored, often glabrous; the bark of the stems becoming white and shining: leaves entire or toothed, the fascicled ones not numerous: inflorescence commonly a loose panicle of close fewheaded cymes.-A form of the arid Lower Sonoran Zone: Antelope Valley, Mohave Desert, Davy, no. 2949; common on the Colorado Desert; Upper San Joaquin Valley. The common form of this variety has entire leaves and glabrous herbage. When the herbage is hispidulous and the inflorescence marked with small bract-like leaves, it is $I$. bracteosa Greene (Tulare Co., ace. to Greene; Bakersfield, Davy, no. 1919, probably). When the leaves are toothed and the herbage pubescent, it is I. leucanthemifolia Greene (desert side San Jacinto Mts., Vandeventer, no. 11). When this form loses its pubescence, it is I. eremophila Greene (Colorado Desert, Wales, no. 17).

Endless forms, other than those mentioned, might be described from the abundant material at hand, but they could be characterized only by various combinations of characters well known to be inconstant. They are therefore best referred to one or the other of the above two varieties.

\section{HAZARDIA Greene.}

Shrubs of suffrutescent plants with brittle ascending stems. Herbage tomentose, or glandular, or quite glabrous, never resinous-punctate. Leaves alternate, coriaceous, entire to spinuloseserrate. Heads chiefly paniculate, 20 to 40 -flowered, turbinate 
or broader, arranged in spikes, racemes, or panicles. Involucral bracts numerous, closely imbricated. Rays yellow, changing to purple, or wanting. Disk-corollas yellow, changing to brownishpurple. Style-appendages very slender, almost terete, minutely pubescent but neither comose nor with a bearded tuft at summit. Achenes linear, 4 to 6-nerved. Pappus reddish.

Herbage white-tomentose: tips of involucral bracts erect 1. H. cana. Herbage green: outer involucral bracts with spreading or recurved tips

2. H. squarrosa.

1. H. cana (Gray) Greene, Pitt. i. 29 (1887). H. detonsa \& serrata Greene, l. c. Diplostephium canum Gray, Proc. Am. Acad. xi. 75 (1876). Corethrogyne cana Greene, Bull. Calif. Acad. i. 223 (1885).

Large shrub "of rather loose habit": herbage densely lanatetomentose, the tomentum sometimes deciduous from the foliage: leaves obovate to oblanceolate, the larger ones sometimes $10 \mathrm{~cm}$. long by $3 \mathrm{~cm}$. wide, entire to sharply serrate: inflorescence paniculate: involucre eampanulate, $12 \mathrm{~mm}$. high; bracts erect, the outer ones with thick tips: rays inconspicuous, yellow, turning to purple (sometimes wanting?) : achenes canescent, prominently nerved.

Guadalupe, San Clemente, Santa Cruz, Santa Rosa, and probably other of the coast islands; often in rocky, inaccessible places. The characters originally assigned to $H$. detonsa and $I I$. serrata are far from constant. For example, specimens from the type locality of $H$. cana exhibit both entire and sharply serrate leaves on the same branchlet (Guadalupe Isl., Anthony, no. 257); while the persistence of tomentum and thickness of leaves may be expected to vary with climatic changes.

2. H. squarrosa (H. \& A.) Greene, Eryth. ii. 112 (1894). Haplopappus squarrosus H. \& A., Bot. Beech. 146 (1833).

Suffruticose at base, 6 to $10 \mathrm{dm}$. high, the erect stems somewhat branching and leafy: herbage finely pubescent and somewhat glutinous: leaves oblanceolate to obovate, obtuse but the strong midrib usually ending in a sharp point, somewhat clasping at the closely sessile base, sharply serrate: heads racemose or paniculate, often 2 or 3 together in a close cluster : involucre turbinate, 10 to $12 \mathrm{~mm}$. high ; bracts imbricated in many series, the 
acutish tips of at least the outer ones recurved or squarrosespreading: rays none: achenes glabrous or sparsely pubescent.

Occasional in the chaparral belt (Upper Sonoran Zone), west of the-mountains, from San Diego and San Bernardino northward to Monterey; also on the Santa Barbara Islands. Aug.Nov. Ace. to Mr. Parish the vernal leaves are $5 \mathrm{~cm}$. long, thin, deciduous before the flowering season, leaving the stems bare below: later leaves ( 2 to $4 \mathrm{~cm}$. long) coriaceous and glutinous in plants of the interior; glutinous, somewhat pubescent, and less rigid in coast plants.

H. oвtusa Greene, Fl. Fr. 375 (1897). Stouter than the last preceding: heads in almost sessile glomerules along the stem or simply spicate: involucre over $12 \mathrm{~mm}$. high, its bracts almost truncate but with a short cusp : achenes glabrous.-Known only from San Emigdio Cañon, Kern Co., but to be expected along our northern borders.

H. OrcutriI (Gray) Greene, Eryth. ii. 112 (1894), occurs in Lower California, reaching nearly to our borders. It is much like H. squarrosa in habit and involueres but is nearly glabrous, has entire acute punctate leaves, and short yellow rays.

H. Berberidis (Gray) Greene, l. c., likewise occurs just over our southern border. It has oval obtuse spinulose leaves, halfclasping at base, obtuse involucral bracts, and numerous showy rays 6 to $12 \mathrm{~mm}$. long.

\section{LESSINGIA Cham.}

Herbaceous plants with alternate leaves, branching stems, and commonly scattered heads of yellow, purplish, or white flowers. Heads rather small, eampanulate to turbinate, 5 to 25 -flowered. Involucral bracts mostly with distinct green tips, imbricated in several appressed ranks. Receptacle flat, alveolate. Flowers perfect. Corollas with linear lobes, either all regular or some of the outer ones enlarged and more deeply eleft on the inner side, the ligule-like limb irregularly 5-lobed. Style-branches tipped with a very short obtuse appendage which bears a more or less conspicuous cusp or subulate prolongation among apical bristles. Achenes all fertile, turbinate or cuneate, more or less flattened, 
silky-villous. Pappus commonly of numerous unequal scabrous bristles, usually turning reddish-brown.

Lessingia finds its nearest relative in Corethrogyne, which it closely resembles in habit and technical characters of the involucre, anther-tips, and style-appendages. And this is true, notwithstanding the fact that Corethrogyne belongs to the Heterochromeae while Lessingia is classed with the Homochromeae; for in the recently discovered $L$. heterochroma we have a Lessingia in which the color of the ray-corollas is strikingly different from that of the disk-flowers, thus tending to break down the distinetion between these subtribes.

Outer corollas enlarged and irregularly cleft.

Stems branching from the base: outer flowers pink

1. L. heterochroma.

Stems erect, branching only above the base: flowers all yellow

2. L. glandulifera.

Corollas all regular (or nearly so) and alike, yellow: var. tenuis of

3. L. ramulosa.

(See also extra-limital species, p. 69.)

\section{L. heterochroma Hall, sp. nov.}

Root annual: stem much branched from the base, the branches decumbent and .5 to $2 \mathrm{dm}$. long: herbage white with a dense tomentum deciduous at time of flowering only from the branchlets, which are then minutely but densely glandular; no tackshaped glands on leaves or involucre: basal leaves numerous, mostly entire, rarely with an obscure lobe, spatulate, obtuse, 1 to $2 \mathrm{~cm}$. long; rameal leaves scattered, entire, spatulate-oblong to linear, obtuse, .5 to $1.5 \mathrm{~cm}$. long: involucre hemispheric, $5 \mathrm{~mm}$. high, 18 to 22 -flowered; outer bracts white with persistent wool, loose, mostly obtuse; inner bracts purple, granular, erect or appressed, imbricated, acute: flowers of two sorts, the 2 or 3 outer series with pink corollas more deeply cleft on the inner side, thus forming an irregularly 5-lobed ligule; inner corollas yellow, regular: style-branches obtuse, short-bristly, the apical prolongation minute or obscure: achenes compressed, canescent with long hairs: pappus-bristles about 20, slightly longer than the diskcorollas, dull white to fuscous.

Dry soil of the Upper Sonoran Zone, Lockwood Valley, Mt. Pinos, Ventura Co., California, Jun. 28, 1905, Hall, no. 6440 
(type); Cuddy Valley, in the same district, Hall, no. 6315. Much like L. Germanorum Cham., of the seaboard, but differing in its more persistent tomentum, entire leaves, glandular peduncles, and pink marginal corollas. Also near L. Lemmoni Gray, of Arizona and eastern California, from which it is distinguished by the color of the flowers and the shape of the style-branches.

2. L. glandulifera Gray, Proc. Am. Acad. xvii. 207 (1882).

Stem erect, stoutish, paniculately much branched above the base, the whole plant 1.5 to $10 \mathrm{dm}$. high : lower part of stem and lower leaves permanently white-tomentose; upper leaves and involucral bracts green, bearing few to numerous yellow tackshaped glands on their margins : lower leaves ovate to oblanceolate, toothed or cleft; those of the branchlets numerous or even crowded, lanceolate or linear, minute: involucre about $5 \mathrm{~mm}$. high, turbinate, 18 to 38 -flowered: flowers all yellow; marginal corollas or some of them enlarged, more deeply cleft on the inner side and simulating a palmately-lobed ligule: achenes flattened, 2 or 3-nerved: ray-pappus shorter than corolla; disk-pappus as long as corolla, fuscous, of about 35 bristles.

Lower to middle California : common on plains of the Upper Sonoran Zone, where the plants are conspicuously glandular and heavy-scented; less plentiful in the lower part of the pine belt (Transition Zone) in the mountains (San Jacinto Mts., Hall, no. 2626 ; and Grant, no. 687), where the glands are minute or quite obsolete and the odor wanting.

3. L. ramulosa tenuis Gray, Bot. Calif. i. 307 (1876); Syn. Fl. i. pt. 2, 162 (1884).

Stems slender, erect but diffuse, the glabrate branches minutely granulose: leaves narrowly oblong, narrowed at base, denticulate or entire, woolly when young, the upper much reduced and entire, some of them clasping: involucre very narrow, 5 to 15-flowered; bracts granular, rarely bearing a few tack-shaped glands: flowers purple, all regular or nearly so and alike: styleappendages with minute setiform tip : achenes scarcely flattened, 4 or 5 -nerved.

Acc. to Gray this variety was gathered by Rothrock at 1550 m. alt., "head of Peru Creek," by which is probably meant Piru Creek, a stream of northeastern Ventura County. 
L. Germanorum Cham. grows near the coast of San Luis Obispo Co. and may be expected further southward. It is a lowbranching species, destitute of glands, with yellow flowers, the outermost of which have irregularly cleft corollas.

L. ALBIFlora Eastwood, Bull. Torr. Club xxxii. 217 (1905), comes from Rose Station, Kern Co. Its sharp-pointed leaves, numerous glands, and white flowers should distinguish it if found within our borders.

L. Lemmoni Gray, Proc. Am. Acad. xxi. 412 (1886), first described from Arizona specimens, has been collected at Indian Wells, Kern Co., by M. A. Knapp, also by Hall \& Chandler, no. 7373, and at Little Owens Lake, Inyo Co., by Purpus, no. 3055, both localities being in the Desert Area just north of our borders. It has a lower habit than $L$. glandulifera, the numerous branehes low and spreading, but can scarcely be distinguished from that species except by the style-branches, which are prolonged into conspicuous subulate tips.

\section{CORETHROGYNE Nutt.}

Perennial herbs, some suffrutescent at base, resembling Aster and flowering mostly in summer and autumn. Herbage whitened when young with a cottony tomentum, which is often deciduous in age. Heads solitary, or cymose, or paniculate. Involucre hemispheric to turbinate, the bracts with green or herbaceous tips. Rays violet-blue or purple; disk yellow. Anthers tipped with subulate appendages. Style-appendages flat, truncate, comose or with a bearded tuft at summit. Achenes pubescent, those of the ray sterile. Disk-pappus reddish-brown, of rigid capillary bristles; ray-pappus reduced or wanting.

\section{SYNOPSIS OF THE VARIETIES OF C. FILAGINIFOLIA.}

Tomentum deciduous from the inflorescence at time of flowering.

Inflorescence minutely if at all glandular: typical................C. filaginifolia. Inflorescence densely glandular and viscid.

Heads small: involucre about $8 \mathrm{~mm}$. high.

Stems tall and slender: heads in loose panicles or racemes.

Seacoast form with numerous heads. var. virgata.

Interior form with few long-pedunculate heads

var. Bernardina. 
Stems low and stout.

Inflorescence paniculate.

Montane form with erect stems var. rigida.

Insular form with depressed or ascending stems.

var. robusta.

Inflorescence virgate, scarcely branched, foliaceous with broad leaves var. glomerata.

Heads large: involucre 10 to $12 \mathrm{~mm}$. high var. Pacifica.

Tomentum persistent, even the involucre white at time of flowering.

Leaves broadly oblong, rigid. ..var. latifolia.

Leaves linear, flaccid. var. linifolia.

1. C. filaginifolia (H. \& A.) Nutt., Trans. Am. Philos. Soc. ser. 2, vii. 290 (1841). Aster? filaginifolius H. \& A., Bot. Beech. 146 (1833).

Slender, erect, 5 to $10 \mathrm{dm}$. high, woody below : herbage arachnoidly tomentose, the tomentum sometimes deciduous, the inflorescence then glabrous or minutely glandular: leaves oblong-spatulate or oblanceolate; the lower ones narrowed to a petiole and sparingly serrate toward the apex; the upper sessile and inclined to be entire; those of the inflorescence reduced to bracts: heads solitary and terminal on the branchlets or more numerous and loosely panicled: involucre campanulate or broadly turbinate, 7 or $8 \mathrm{~mm}$. high; its bracts imbricated in 4 or 5 series, narrowly lanceolate, erect : rays 15 to 25 , violet.

Near the coast from Monterey southward, the typical form rare south of Santa Barbara. In Monterey Co. the specimens have a merely granular inflorescence; proceeding southward along the coast we find forms in which the glandular pubescence is more and more pronounced, until in Southern California a majority of the plants have viscid stalked glands on the inflorescence (var. virgata). In the type specimens (of which I have seen a sketch) the solitary heads terminate widely spreading branchlets, but this form passes directly into one with numerous paniculate heads. The following are only the extreme forms of this very polymorphic species.

Var. latifolia Hall, var. nov. Five dm. or more high; the stems stout, woody below: herbage densely white-tomentose, the tomentum not deciduous even from the involucres at time of flowering: lower leaves narrowed to the base; principal cauline 
leaves broadly oblong or slightly narrowed to the closely sessile base, shallowly toothed at the very obtuse summit, 3 or $4 \mathrm{~cm}$. long, 8 to $12 \mathrm{~mm}$. broad : inflorescence paniculate, with numerous bractlike leaves: involuere turbinate, 8 or $9 \mathrm{~mm}$. high; bracts imbricated in about 5 series, their tips slightly spreading: rays 20 to 25 : style-appendages flat, obtuse, tipped with a brush-like tuft of bristles.-Oxnard, Ventura Co., Davy, nos. 7815 (type), 7814, 7813.

Var. virgata (Benth.) Gray, Bot. Calif. i. 320 (1876). C. virgata Benth., Bot. Sulph. 23 (1844). Six to $10 \mathrm{dm}$. high, the stems slender: tomentum early deciduous, especially above, leaving the herbage green; inflorescence viscid-glandular, the numerous glands usually short-stipitate: heads numerous, in a diffuse panicle.-The common form along the coast from western San Diego Co. north to Monterey.

Var. Bernardina (Abrams) Hall, comb. nov. C. virgata Bernardina Abrams, Fl. L. A. and Vic. 401 (1904). Commonly 6 to $8 \mathrm{dm}$. high; the stems slender: tomentum deciduous from the involucres and uppermost portion of the peduncles, the exposed parts then glandular: heads few, terminating the long divaricate branches of a very loose panicle or raceme.-The common form of the foothills and plains back from the seacoast, especially in the San Bernardino Valley.

Var. linifolia Hall, var. nov. Herbaceous throughout, $4 \mathrm{dm}$. or less high; stems numerous, erect, widely branched above, the slender branches terminated by solitary heads: herbage densely and permanently white-tomentose, even to the involucres: leaves crowded below, more scattered above, all narrowly linear, 2 to 5 cm. long, mostly $1 \mathrm{~mm}$. (some $3 \mathrm{~mm}$.) broad; not at all rigid: involucre broadly turbinate, 8 or $9 \mathrm{~mm}$. high; bracts closely imbricated in about 5 ranks, the tips slightly spreading: rays about 20, violet, $6 \mathrm{~mm}$. long.-About one kilometer south of Del Mar, San Diego Co., Aug. 5, 1906, Mrs. K. Brandegee. The type of the variety is Univ. Calif. sheet no. 73319. The specimens grew in hard siliceous soil on an exposed wind-swept bluff overlooking the sea. The surrounded vegetation was all stunted in growth, and this variety exhibits in its narrow often revolute leaves, dense tomentum, and low stature, the xerophytic characters to be ex- 
pected in such situations. It is to be noted, however, that Mrs. Brandegee also gathered near this same station specimens with narrowly lanceolate leaves up to $6 \mathrm{~mm}$. in breadth and stems up to $7 \mathrm{dm}$. in height, and that this botanist is of the opinion that gradations into the var. virgata may be found by careful search.

Var. rigida Gray, Syn. Fl. i. pt. 2, 170 (1884). C. incana var.? Benth., Pl. Hartweg. 316 (1849). C. rigida Heller, Muhlenbergia ii. 256 (1906). Stout and rigid, from a woody base, commonly less than $5 \mathrm{dm}$. high: tomentum dense, only tardily deciduous, the whole inflorescence then glandular and viscid: leaves spatulate-lanceolate to oval or obovate: heads in an open panicle: involucre eampanulate, its bracts with distinct green tips.-In dry soil in the mountains from San Jacinto Mt. (Hall. No. 2530) to the Sierras of Tulare Co. (Mrs. Brandegee).

Var. robusta Greene, Pitt. i. 89 (1887). "Suffrutescent and low, the thick somewhat depressed or ascending branches only a foot [3 dm.] high : panicle green and glandular-viscid, other parts whitish with an appressed tomentum."-San Miguel Island, among high rocks, and also on the top of Prince's Island, both acc. to Greene.

Var. glomerata Hall, var. nov. Plant somewhat woody at base, about $3 \mathrm{dm}$. high, the stout stems erect and very rigid: herbage clothed with a dense white wool which is tardily or not at all deciduous except from the involueres, which are glandularviscidulous: leaves numerous, appressed, oblong to obovate, entire, all but the lower ones sessile by a broad (sometimes clasping) base, the larger ones $4 \mathrm{~cm}$. long-by $1.5 \mathrm{~cm}$. wide: inflorescence virgate, the heads appearing singly or 2 to 4 together in the axils of the upper scarcely reduced leaves along the simple erect stems : involucre turbinate, 8 or $9 \mathrm{~mm}$. high; its bracts closely imbricated in about 4 series, the slender tips green and spreading or recurved: rays about 15 , violet, about $8 \mathrm{~mm}$. long: styleappendages with a rather conspicuous tuft of bristles.-Oak Glen, Yucaipe Ranch, near Redlands, at 1500 m. alt., Nov., 1903, Rev. Geo. Robertson, no. 117. - The same botanist has gathered a very similar form at Forest Home, San Bernardino Mts., but this has some of the glomerules on distinct lateral shoots. Specimens collected at Tehachapi, Kern Co., by Miss Alice Eastwood, Sept. 29, 
1894, are similar except that the inflorescence is less leafy and the glomerules of somewhat smaller sessile heads are sometimes on peduncles $1 \mathrm{~cm}$. long. The variety as described is much like var. rigida save in the inflorescence and upper leaves.

Var. Pacifica Hall, var. nov. Plant stout, erect, $6 \mathrm{dm}$. or more high : tomentum floceose, deciduous from the branchlets and involucres at time of flowering, the inflorescence then conspicuously glandular and viscid: cauline leaves narrowly lanceolate, acute, entire or few-toothed, mostly 3 to $5 \mathrm{~cm}$. long and $8 \mathrm{~mm}$. or less broad: heads large, numerous, in an open panicle: involucre hemispheric, 10 to $12 \mathrm{~mm}$. high : bracts imbricated, linear, acuminate, greenish except at the chartaceous and strongly nerved base but without distinct green tips: rays about 30, violet or purple: pappus varying from nearly white to purplish brown.-Pacific Beach, near San Diego, summer of 1899, Purpus. The type of the variety is Univ. Calif. sheet no. 31267. It was gathered on slopes just back from the beach and grew in rich, loose soil along a railroad embankment. Exactly the same form, except for the more distinctly green-tipped involucral bracts, has been collected by Mrs. Brandegee in a similar situation near Del Mar, Aug. 5, 1906.

\section{PSILACTIS Gray.}

Ours a leafy-stemmed desert annual. Heads rather small, solitary or loosely racemose, heterogamous. Involucre hemispheric; its bracts unequal, closely imbricated in 2 or 3 series. Ray-flowers pistillate, often infertile. Disk-flowers perfect, fertile. Achenes compressed, pubescent. Pappus of ray-flowers none or an obscure ring, of disk-flowers a row of slender bristles.

1. P. Coulteri Gray, Pl. Fendl. 71 (1849).

Loosely branched throughout, 2 or $3 \mathrm{dm}$. high : herbage roughpubescent and glandular (varying to glabrous, ace. to Gray): leaves lanceolate or narrowly oblong (the lower tapering to a petiole, the upper closely sessile and appressed), coarsely and sharply toothed or pinnatifid, 1 to $3 \mathrm{~cm}$. long, 2 to $6 \mathrm{~mm}$. broad, those of the branchlets much reduced and rarely entire: involuere about $4 \mathrm{~mm}$. high; bracts oblong, very acute, green and herba- 
ceous save at the white-scarious base: rays 25 to 35 (60 to 80 , ace. to Gray), lavender, about $5 \mathrm{~mm}$. long: disk-flowers yellow: achenes lnear; those of the disk with 20 to 40 unequal pappusbristles.

Lower Sonoran Zone: Warm Springs, near Newberry, Mohave Desert, Parish, no. 1252; sand hills near Hector and near Barstow, in the same district, Hall, nos. 6118, 6833; southern Arizona and adjacent Mexico.

\section{MONOPTILON T. \& G.}

Depressed desert annuals with short radiating or ascending branches and upturned heads of daisy-like flowers. Involucre campanulate, of equal linear bracts. Receptacle naked, flat. Rays conspicuous, normally white but often tinged with rose. Disk yellow. Achenes narrowly obovate, compressed, nerved along the margins, pubescent with emarginate hairs. Pappus alike in ray and disk.

As here treated, Monoptilon consists of but two species heretofore considered as constituting two distinct genera, mainly because of a difference in their pappus characters. But these characters are more variable than was formerly supposed, the only constant differences being a minute coroniform toothed pappus with a single plumose awn, in the one case, and a paleaceous pappus with 1 to 12 scabrous awns, in the other. The diskflowers are also more conspicuously villous in the first species than in the second. But in all other characters, in general aspect, and in distribution, the two are very similar, and may therefore be received into a single genus.

1. M. bellidiforme.

Pappus-awns 1 to 12 , not plumose, alternating with paleae

2. M. bellioides.

1. M. bellidiforme T. \& G., Journ. Bost. Soc. Nat. Hist. v. 106, t. 13 (1847).

Stem much branched, the branches commonly spreading and seldom over $5 \mathrm{~cm}$. long: herbage villous-hirsute: leaves spatulate or linear-spatulate, 5 to $20 \mathrm{~mm}$. long, alternate: involucre $5 \mathrm{~mm}$. 
high: rays numerous, the obovate or oblong ligule about $5 \mathrm{~mm}$. long: corolla-tube in both ray and disk-flowers sparsely longvillous with jointed hairs; pappus a minute barely denticulate crown and a single setiform awn which is short-plumose toward the tip.

On dry plains.within the Lower Sonoran Zone of the Mohave Desert (Hesperia, Warren's Well, Rabbit Springs, Cushenberry Springs, Kramer, Yucca), east to Utah; much less common than no. 2.

2. M. bellioides (Gray) Hall, comb. nov. Eremiastrum bellioides Gray, Pl. Thurb. 321 (1854); Torr. Pacif. R. Rept. v. 361, t. 6 (1857). E. Orcuttii Wats., Proc. Am. Acad. xxv. 132 (1890). E. bellioides Orcuttii Coville, Contr. U. S. Nat. Herb. iv. 125 (1893). Desert Aster.

Characters the same as for $E$. bellidiforme except as follows: ray-corollas with sparsely villous tube; disk-corollas with either glabrous or very sparsely pubescent tube: pappus of 3 to 12 oblong or cuneate more or less setose-pinnatifid paleae and 1 to 12 slender nonplumose bristles.

Very common in sandy soil, springing up after the rains, throughout the Lower Sonoran Zone of the Desert Area, from our southern boundary to Inyo Co.; east into Arizona, Utah, etc.

The type of this species was gathered by George Thurber in southeastern Imperial Co., from which district also came the type of Dr. Watson's Eromiastrum Orcuttii. This latter species was distinguished from $E$. bellioides by the pappus of 5 paleae alternating with as many bristles twice as long. Dr. Coville has already pointed out (1. c.) the intergradation between thse forms, especially as regards the number of pappus-bristles, and recent collections indicate that the number of paleae are also variable. In specimens from the east base of San Jacinto Mt., Hall, no. 1836, the awns and paleae are 8 each. In plants from Rhyolite, Nevada, Shockley, no. 62, the pappus consists almost uniformly of 3 lacerate paleae and 1 bristle; rarely a second shorter bristle arises from the margin of a palea. 


\section{ASTER I. ASTER.}

Late-aestival or autumnal herbs or rarely shrubs, with alternate leaves and commonly showy heads. Inflorescence various. Heads heterogamous with usually fertile ray-flowers, or homogamous through the deficiency of rays. Involucre turbinate or campanulate to hemispheric, the bracts imbricated in several ranks. Disk-corollas yellow, changing to purple or brown, tubular, the limb shortly 5-toothed. Receptacle plane or convex, pitted. Style-branches flattened, their appendages subulate or lanceolate and acute. Achenes compressed. Pappus copious, of simple capillary bristles.

\section{A.-Perennials: tips of involucral bracts erect: herbage pubescent except} in nos. $2,12,13$, and 14.

Pappus of coarse rigid bristles: desert species with woody stems and large solitary heads.

Leaves acuminate: peduncles elongated

1. A. tortifolius.

Leaves obtuse: peduncles short. 2. A. Orcuttii.

Pappus fine and soft.

Rays conspicuous: stems herbaceous.

Stems leafy (leaves early deciduous in no. 5): polycephalous except in forms of no. 11.

Involueral bracts with broad green tips, closely imbricated.

Inflorescence distinctly eymose: insular species with coriaceous leaves 3. A. radulinus.

Inflorescence .racemose or paniculate.

Plants over $35 \mathrm{~cm}$. high: foothills and valleys.

Herbage rough-pubescent or almost glabrous: inflorescence mostly condensed: leaves rigid

4. A. Menziesii.

Herbage soft-pubescent or glabrous : infloreseence mostly rather loose.

Rameal leaves linear, $6 \mathrm{~mm}$. or less wide.

Inflorescence with minute rigid bracts (these 5 mm. long) ........................... A. defoliatus.

Inflorescence leafy-bracteate ...6. A. Bernardinus.

Rameal leaves lanceolate, mostly 8 to $20 \mathrm{~mm}$. wide 7. A. Chilensis.

Plant 15 to $30 \mathrm{~cm}$. high: mountains above $1200 \mathrm{~m}$.: var. Parishii of. 10. A. Fremonti. 
Involucral bracts narrowed above to a point, not closely imbricated.

Principal leaves broadly lanceolate or wider: plant 4 to $7 \mathrm{dm}$. high: foothill eañons. 8. A. Greatai.

Principal leaves narrowly lanceolate to linear.

Plant 6 to $20 \mathrm{dm}$. high: heads numerous ...9. A. hesperius. Plants 1.5 to $6 \mathrm{dm}$. high: heads rather few: mountains above $1200 \mathrm{~m}$.

Leaves not sheathing: var. Parishii of.

10. A. Fremonti.

Lower leaves sheathing the stem, elongated.

11. A. delectabilis.

Stems leafless except at base, monocephalous: high-mountain species 12. A. Andersonii.

Rays small and white or none: desert species with rush-like nearly leafless stems (often woody at base).

Achenes sericeous-pubescent: rays none.

13. A. carnosus.

Achenes glabrous: rays white, $3 \mathrm{~mm}$. long.

14. A. spinosus.

B.-Annuals and biennials: tips of involucral bracts erect: herbage glabrous except in no. 16.

Leaves entire, or merely toothed.

15. A. exilis.

Leaves pinnately parted or cleft

16. A. tanacetifolius.

C.-Biennial or perennial: at least the outer involucral bracts with subulate recurved tips: herbage pubescent.

Branching plant with showy heads in terminal cymes or panicles

17. A. canescens.

1. A. tortifolius (T. \& G.) Gray, Proc. Am. Acad. vii. 353 (1868); not A. tortifolius Michx., Fl. ii. 109 (1803) which is now Sericocarpus tortifolius. Haplopappus tortifolius T. \& G., Journ. Bost. Soc. Nat. Hist. v. 109 (1845). Aster Mohavensis Coville, Contr. U. S. Nat. Herb. iv. 126 (1893); not A. Mohavensis Kuntze, Rev. Gen. 318 (1891). Xylorhiza tortifolia Greene, Pitt. iii. 48 (1896). Mohave Aster.

Woody at base, about $6 \mathrm{dm}$. high; bark white: herbage tomentose, at least when young: leaves linear to oblong, attenuate to a sharp point, entire to incisely pinnatifid, the teeth or lobes commonly pungent: involucral bracts linear-attenuate, imbricated in 2 or 3 unequal series: rays about 40 to 60 , lavender: achenes white-villous: pappus of comparatively few rigid bristles, deciduous in a ring. 
Common in stony soil of the Lower Sonoran Zone from the northern borders of the Colorado Desert (Santa Maria Mts., Chuckawalla Bench, Cottonwood Pass) across the Mohave to Owens Valley, Inyo Co., and the Charleston Mts., Nevada.

2. A. Orcuttii Vas. \& Rose, Bot. Gaz. xvi. 113, t. 11 (1891). Xylorhiza Orcuttii Greene, l. c. Orcutt Aster.

Suffruticose, very leafy up to the large heads, 5 to $8 \mathrm{dm}$. high; bark pearly-white: herbage glabrous: leaves obovate to oblong, 2.5 (to 5 ?) $\mathrm{cm}$. long, spinulose-toothed, obtuse and cuspidate or acute, the lower ones cuneate at base, the upper ones sessile by a broad base: involucral bracts closely imbricated, linear-lanceolate, the slender green tips often much elongated, usually ciliate on the margins below : rays $2 \mathrm{~cm}$. long, purple or "lavender to delicate mauve color"': achenes white-villous.

Lower Sonoran Zone of the Colorado Desert: Cariso Creek wash, Dec. 5, 1890, Orcutt; Borregos Springs, Apr., 1895, Brandegee (leaves acute and bracts ciliate); Shaver's Well, east of Mecca, Schellenger, no. 70 (bracts glandular, not ciliate); hills just north of Indio, Hall \& Greata, no. 5994; Split Mt., Apr., 1905, Brandegee. Very common at Cariso Creek, ace. to Orcutt.

3. A. radulinus Gray, Proc. Am. Acad. viii. 388 (1872). Broad-Leaved Aster.

Root perennial: stems .7 to $5 \mathrm{dm}$. high, branching above into a broad open cyme: herbage scabrous-pubescent: leaves ovalobovate to oblong, $10 \mathrm{~cm}$. or less long, sharply serrate above the entire (often attenuate) base: involucre turbinate, 6 to $8 \mathrm{~mm}$. high; bracts imbricated, the outer successively shorter, villouspuberulent, abruptly acutish or obtuse : rays 5 to $10 \mathrm{~mm}$. long, whitish: achenes minutely pubescent.

Santa Cruz Island, Santa Barbara Co., ace. to Greene $;^{12}$ Monterey Co. to Washington and Nevada.

4. A. Menziesii Lindl., in Hook., Fl. Bor. Am. ii. 12 (1834) : Torr., Wilkes Exped. xvii. 341, t. 8 (1874). Purple Aster.

Five to $8 \mathrm{dm}$. high: stems commonly several from the woody root, erect and rigid, simple or with a few virgate branches above, very leafy up to the inflorescence but commonly naked below at

12 Bull. Calif. Acad. ii. 401 (1887). 
flowering time: herbage scabrous with a short rigid pubescence, the stems sometimes almost glabrous: leaves rigidly erect or ascending, narowly lanceolate, sessile by a broad subcordate base, acute, remotely serrate or entire, the larger 7 or $8 \mathrm{~cm}$. long by 1 $\mathrm{cm}$. wide: inflorescence commonly a close raceme; the rigid erect peduncles very short, clothed with small linear bracts : involucre 6 $\mathrm{mm}$. high, its bracts with obtuse or merely acutish tips: rays "violet or purple," $6 \mathrm{~mm}$. long. (Plate 1.)

Dry ground throughout western California; not common in our district: Antelope Valley, 1895, Davidson; Los Angeles, Davidson; Cuyamaca Mts., San Diego Co., Oct. 15 and 16, 1894, Brandegee; near San Diego, W. S. Wright, no. 74; San Diego Co., Mary T. Reynolds; Witch Creek, San Diego Co., Alderson, no. 348; Oxnard, Davy, no. 7808. These last three citations are of imperfect and doubtful specimens.

\section{A. defoliatus Parish, Bot. Gaz. xxxviii. 461 (1904).}

Slender but rigid, about $1 \mathrm{~m}$. high, divaricately much branched above, leafless when mature except on the flowering branches: herbage minutely pubescent or the older parts glabrous: lower leaves not known; upper cauline leaves narrow and apparently linear, but only basal fragments seen; leaves of the branchlets linear, acute, rigid, $1 \mathrm{~cm}$. or less long, less than 1 $\mathrm{mm}$. wide: heads solitary or 2 to 4 together terminating the branchlets the lower of which are often $15 \mathrm{~cm}$. long while the upper are much shortened; the whole inflorescence thus appearing as a very loose panicle: involuere $6 \mathrm{~mm}$. high, its bracts with broad scarious margins below: "rays about 40, light violet" (Parish) : style-appendages lanceolate-acuminate.

Known only from the original collection; in a meadow at San Bernardino, Oct. 17, 1903, Parish, no. 5335.

6. A. Bernardinus Hall, sp. nov.

Plant 4 to $8 \mathrm{dm}$. high: stems several from a perennial base, erect, densely leafy throughout or the lower leaves deciduous: herbage conspicuously cinereous with a dense short and very soft pubescence: leaves loosely spreading or reflexed, linear to linearlanceolate, 3 to $5 \mathrm{~cm}$. long by 3 to 5 (rarely 7 ) $\mathrm{mm}$. wide, those of the branchlets much smaller. heads in short or elongated 
simple racemes or these branehing to form an elongated panicle; uppermost heads in congested clusters: peduncles (commonly 2 $\mathrm{cm}$. long) with linear overlapping bracts : involucre $7 \mathrm{~mm}$. high; its bracts canescent, closely imbricated, the green tips obtuse : rays 30 to 35 , about 7 (6 to 10 ) $\mathrm{mm}$. long, deep blue (commonly brown in dried specimens) : style-appendages linear to lanceolate in ray-flowers, broadly lanceolate in disk-flowers: achenes canescent: pappus fine and soft, sordid. (Plate 2.)

In meadows, vicinity of San Bernardino, California, at an altitude of 300 m., Sept. 5, 1905, S. B. Parish, no. 5543; same locality and collector, Sept., 1891; also Sept. 15, 1896, no. 4198; Orange Co., C. W. Hamlin, no. 25; Cienega, near Los Angeles, Braunton, no. 637; near Pomona, Davy, no. 2870. The type is Univ. Calif. sheet no. 72044 (Parish, no. 5543).

This species is intermediate between $A$. defoliatus and $A$. Chilensis. It differs from the former in its lower stature, more compact and leafy inflorescence, and larger heads; from the latter in its more numerous and narrower leaves and bracts; and from both of these species in its dense einereous pubescence. From A. Menziesii, with which it has been confused, it may be distinguished by its lax foliage, soft pubescence, etc. Some of the specimens collected by Parish under no. 5543 have a remarkably secund inflorescence, the heads all on short horizontal leafybracteate branchlets (these 2 or $3 \mathrm{~cm}$. long). This is probably due to ecologic causes, the plants being otherwise typical.

7. A. Chilensis Nees, Ast. 133 (1832). A. Chamissonis Gray, Wilkes Exped. xvii. 341 (1874).

Five to $10 \mathrm{dm}$. high, with loosely spreading branches above: herbage villous-pubescent or glabrate: leaves lanceolate, sessile by a half-clasping base, $10 \mathrm{~cm}$. or less long, commonly 1 or $2 \mathrm{~cm}$. wide, the upper entire and passing gradually into the bractlike ones of the inflorescence, the oblong-spatulate radical ones remotely serrate and attenuate into a petiole, all commonly with seabrous-ciliolate margins: involucre 6 to $8 \mathrm{~mm}$. high: rays white, lavender, or bluish, 8 to $12 \mathrm{~mm}$. long.

Low or marshy ground of western California, including the islands; rare within our limits, and perhaps not occurring south 
of Santa Barbara Co., more common further north: Carpinteria, Hall, no. 3166 (a very pubescent form); Santa Rosa Island, Brandegee.

8. A. Greatai Parish, Bull. So. Calif. Acad. i. 15 (1902).

Plant 4 to $7 \mathrm{dm}$. high, with erect or assurgent slender stems : herbage nearly glabrous to soft-pubescent above: leaves ample, thin, from ovate to oblong or broadly oblanceolate, tapering below to a broad or sometimes half-clasping base, mostly 6 to 12 $\mathrm{cm}$. long by 2.5 to $4 \mathrm{~cm}$. broad, acute, remotely serrate, the reduced linear upper ones entire: heads in a very open panicle: involucre fully $7 \mathrm{~mm}$. high, its loosely imbricated bracts linearlanceolate and pubescent at least on the margins : rays 30 to 40 , light purple, 5 to $10 \mathrm{~mm}$. long: style-appendages linear-subulate: achenes short-hirsute: pappus sordid.

Apparently confined to Upper Sonoran cañons of the San Gabriel Mts., where, however, it is not uncommon. The type was collected in Eaton Cañon, Sept. 30, 1900, by L. A. Greata.

Very close to $A$. patulus Lam., if not indeed only a form of that eastern species, possibly a garden escape. But the general habit and leaves are somewhat different and the plants are not red-stemmed. Also related to A. prenantlioides Muhl., from which it is distinguished by its softer pubescence, which is not arranged on lines on the stem nor scabrous on the upper surface of the leaves.

9. A. hesperius Gray, Syn. Fl. i. pt. 2, 192 (1884). A. ensatus Greene, Pitt. iv. 223 (1900). A. aestivus Gray, Bot. Calif. i. 614 (1876); not $A$. aestivus Ait.

Stems tall, leafy throughout, coarsely pubescent in lines above: leaves firm, narrowly lanceolate, sessile by a broad base, acuminate above, perfectly glabrous except for the minutely setose-ciliate margins; the lower $1 \mathrm{dm}$. or more long by about $13 \mathrm{~mm}$. wide, sharply serrate; the upper smaller and entire: heads numerous, in an open panicle: peduncles elothed with linear overlapping bracts: involucre $6 \mathrm{~mm}$. high; its linear ciliate bracts nearly equal, the inner with green tip and midnerve, the outer similar or wholly herbaceous: rays more than 30 , nearly $1 \mathrm{~cm}$. long, purple. 
Upper Sonoran Zone, in meadows and other moist places: near San Bernardino, Oct., 1895, at altitudes of 305 to $450 \mathrm{~m}$., Parish, no. 3818 (type number of A. ensatus); Julian, San Diego Co., at an altitude of 1280 m., Dunn; Falls of San Diego River, Brandegee; Cienega, near Los Angeles, acc. to Davidson.

10. A. Fremonti Parishii Gray, Syn. Fl. i. pt. 2, 192 (1884).

Stems slender, sometimes simple and ending in a solitary head, more commonly terminating in a short cymose panicle, the plant seldom over $3 \mathrm{dm}$. high: herbage more or less pubescent, especially in the inflorescence: radical leaves lanceolate to obovate, tapering to a distinct margined petiole which is widened at base: upper leaves linear to narrowly oblong, sessile, 4 to 8 $\mathrm{cm}$. long: involucre 5 to $8 \mathrm{~mm}$. high, its bracts ciliolate, otherwise glabrous or sparsely pubescent: rays numerous, about $6 \mathrm{~mm}$. long, blue fading to violet.

Occasional in meadows, etc. of the Transition Zone, San Bernardino and San Jacinto Mts.; San Gabriel Mts., according to Davidson. A. adscendens of McClatchie's list is probably the same.

The involucral bracts vary from spatulate, obtuse, and closely imbricated to linear or oblong, acute, and nearly equal in length. Both forms of involucre occur on different plants from a single locality as also do intermediate forms.

\section{A. delectabilis Hall, sp. nov.}

Plant 15 to $40 \mathrm{~cm}$. high, with slender perennial rootstocks: stems slender, erect, simple up to the inflorescence, reddishtinged, glabrous below, minutely pubescent above with soft white hairs, leafy throughout: leaves thin, entire or rarely with a few obscure teeth, glabrous except on the margins which are minutely ciliate-scabrous, especially below; basal leaves narrowly oblanceolate, obtuse or acute at apex, tapering below to a petiolelike portion the closely sessile base of which is somewhat expanded and sheathing, entire leaf 12 to $24 \mathrm{~cm}$. long, 15 to $18 \mathrm{~mm}$. wide; upper leaves similar but narrower and always acute, the basal portion less sheathing: peduncles short, their small bracts acuminate from a broad base: heads commonly only one or two: involucre 8 to $10 \mathrm{~mm}$. high, about $15 \mathrm{~mm}$. broad, either sub- 
tended by a few linear bracts or naked; involucral bracts linear, acute, loosely imbricated in about 3 series, strongly ciliate but otherwise glabrous, green and herbaceous throughout except for a very narrow white or reddish margin : rays 25 to 35,10 to 15 $\mathrm{mm}$. long, $2 \mathrm{~mm}$. broad: achenes strigose-pubescent: pappus tawny. (Plate 3.)

Open marshy meadow at an altitude of $1980 \mathrm{~m}$., on a tributary of Mill Creek, about 6 kilometers northeast of Tyler's Retreat, San Bernardino Mts., California, Aug. 30, 1904, Dr. R. J. Smith, no. 76 .

The collector writes as follows: "As I remember the plants they were from 8 to 14 inches high, mostly simple with a single terminal head, but others had 4 or 5 heads. They grew quite freely in this one locality but I have not seen them elsewhere." This species is apparently related to both A. Fremonti Gray and A. occidentalis Nutt. Further collections may reveal intermediate forms connecting it to one of them, but at present it may be distinguished by the large sheathing lower leaves and the larger heads with longer rays. The type is in the Herbarium of the University of California.

12. A. Andersonii Gray, Proc. Am. Acad. vii. 352 (1868). Erigeron Andersonii Gray, l. c. vi. 540 (1865). Oreastrum Andersonii Greene, Pitt. iii. 147 (1896). Oreostemma Andersonii Greene, Pitt. iv. 224 (1900).

Scapiform stems erect or assurgent, $2.5 \mathrm{dm}$. or less high, from a thick perennial caudex: herbage glabrous throughout or the young parts tomentulose: radical leaves numerous, grass-like, 5 to $10 \mathrm{~cm}$. long, 3 to $5 \mathrm{~mm}$. broad, acute, entire, nervose when dry; leaves of the scape-like stems few, reduced to short bracts: involucre $9 \mathrm{~mm}$. high, its nearly equal bracts oblong, acute, scarious or reddish-margined: rays purple, $12 \mathrm{~mm}$. long: styleappendages filiform.

Wet meadows of Tahquitz Valley, San Jacinto Mt., in the Upper Transition Zone, and to be expected in the San Bernardino Mts. Common in the Sierra Nevadas.

13. A. carnosus Gray, Syn. Fl. i. pt. 2, 202 (1884). Linosyris? carnosa Gray, Pl. Wright. ii. 80 (1853). Bigelovia in- 
tricata Gray, Proc. Am. Acad. xvii. 208 (1882). Leucosyris carnosa Greene, Fl. Fr. 384 (1897); Pitt. iii. 243 (1897).

A rigidly much branched shrub, 6 or $8 \mathrm{dm}$. high, with slender pale branches and inconspicuous scale-like leaves: leaves linear or subulate, entire, mostly .2 to $1 \mathrm{~cm}$. long, the lower fleshy ones sometimes $2 \mathrm{~cm}$. long : heads solitary, terminating geniculate or widely spreading branchlets : involucre $6 \mathrm{~mm}$. high; its lanceolate-acuminate imbricated bracts chartaceous, with a greenish midrib: rays none: style-branches linear-subulate: achenes sericeous-pubescent.

Restricted chiefly to the Lower Sonoran Zone of the Mohave Desert and Inyo Co., not common: alkaline meadow near Colton, Parish, no. 2005 ; Rabbit Springs, Parish, no. 1453; alkaline plains of Antelope Valley; etc.

14. A spinosus Benth., Pl. Hartw. 20 (1839). Leucosyris spinosa Greene, Pitt. iii. 244 (1897). Mexican Devil-weed.

Slender, reedy, 6 to $12 \mathrm{dm}$. high and herbaceous throughout (12 to $25 \mathrm{dm}$. high and shrubby in the Mexican form), branching above, the ascending branchlets terminated by solitary heads, or ending in short racemes : herbage light green, glabrous : leaves few, linear, mostly less than $2 \mathrm{~cm}$. long (basal sometimes $5 \mathrm{~cm}$.), often with spines in or above their axils, only the upper subulate scale-like ones present at time of flowering: involucral bracts lanceolate, acute, sometimes minutely pubescent or ciliate, brown or greenish, with a scarious or reddish border : rays white, drying brown, $3 \mathrm{~mm}$. long: style-branches triangular-subulate: achenes glabrous.

South San Diego, Chandler, no. 4013; Tia Juana Valley, San Diego Co., Alderson, no. 971; Colorado Desert, Davy, no. 8016, Schellenger, no. 3, etc.; thence to Texas and Central America. According to Mr. J. E. Roadhouse, this species gives promise of becoming a very troublesome weed in Imperial Valley, Colorado Desert. He observes that the plants become 9 to $12 \mathrm{dm}$. high the first season and that by the end of the second season they have thrown out numerous rhizomes $2 \mathrm{~m}$. or more long. The style-branches in Guatemalan specimens have been described as very short and obtuse. ${ }^{13}$ In ours the tips are ovate or lanceolate and acute.

13 Coulter, Bot. Gaz. xx. 46 (1895). 
15. A. exilis Ell., Sketch ii. 344 (1824). Slender Aster.

A slender erect annual, 3 to 10 or $12 \mathrm{dm}$. high, ending above in an open panicle: herbage glabrous: leaves glabrous, 6 to 12 $\mathrm{dm}$. long and 3 to $6 \mathrm{~mm}$. wide (or some of the lower ones oblanceolate or oblong and 6 to $10 \mathrm{~mm}$. wide), entire or rarely serrate, those of the inflorescence lanceolate-subulate: involucre 5 or $6 \mathrm{~mm}$. high; its bracts linear, acute, herbaceous, scariousmargined : rays light-pinkish or purple, $3 \mathrm{~mm}$. long: pappus fine and soft.

A common weed along river-bottoms and in waste or wet places generally. Aug.-Oct.

16. A. tanacetifolius HBK., Nov. Gen. Sp. iv. 95 (1820). Machaeranthera tanacetifolia Nees, Ast. 225 (1832) ; Hook., Bot. Mag. t. 4624 (1852).

Erect, 2 to $4 \mathrm{dm}$. high : stem leafy, commonly simple below, cymosely branched above, the ultimate branches terminated by solitary showy heads: herbage finely pubescent: leaves 1.5 to 3 cm. long, oblong in outline, pinnately parted into few linear widely spreading segments, or the lowest 2 to 3-pinnately parted, some of the uppermost varying to linear and entire: involucre 8 or $9 \mathrm{~mm}$. high; bracts linear-acuminate, the basal portion scarious, the viscid-pubescent tips green : rays bright violet; 8 to $10 \mathrm{~mm}$. long: achenes striate, canescently villous : pappus-bristles rather rigid.

Providence Mts., Cooper, acc. to Gray : thence east and south.

A. PARVIFlorus Gray, occurs in western Arizona and may reach our borders. It is not so tall as $A$. tanacetifolius : herbage glabrous but somewhat viscid: leaves simply pinnatifid, $2 \mathrm{~cm}$. or less long; lobes very short: involucral bracts linear-oblong, with ovate acute green tips: rays purple, $6 \mathrm{~mm}$. long: achenes sericeous : pappus soft, rather scant.

17. A. canescens Pursh, Fl. ii. 547 (1814). Machaeranthera Pinosa Elmer, Bot. Gaz. xxxix. 49 (1905).

Plant 3 to $5 \mathrm{dm}$. high, from a biennial or perennial root: herbage minutely pubescent but usually green, inflorescence and involucres glandular: lower leaves spinose-dentate, oblanceolate, 5 cm. or less long, including the winged petiole; the upper becom- 
ing linear and entire: heads terminating bracted branches of the cymose panicle: involucre $1 \mathrm{~cm}$. high, imbricated, the green tips of the bracts recurved at least in mature heads : receptacle alveolate, the alveoli toothed: rays few, 5 to $15 \mathrm{~mm}$. long, bluishpurple, rarely wanting: achenes narrowed below, pubescent.

In the San Bernardino Mts. at Barton Flat, Mrs. Wilder, no. 603, and at Gold Mt., Grinnell, no. 91, also on South Fork, Santa Ana River, Hall, nos. 7525, 7672; Swartout Cañon, San Antonio Mts., Geo. R. Hall (heads mostly discoid, some with 1 or 2 rays); Frazier Mt. and Mt. Pinos, Ventura Co., Hall, nos. 6597, 6678 (uniformly discoid) ; Mt. Pinos, ace. to Elmer (1. c. under Machaeranthera Pinosa, heads radiate); Providence Mts., Brandegee.

Var. tephrodes Gray, Syn. Fl. i. pt. 2, 206 (1884). A. incanus Gray, Bot. Calif. i. 322 (1876). Machaeranthera tephrodes Greene, Pitt. iv. 24 (1899)? Root probably always biennial: herbage canescent, especially the broad involucres, the bracts of which are provided with long attenuate herbaceous tips: rays numerous, about $1 \mathrm{~cm}$. long.-San Jacinto Valley, Colorado Desert, and east into Arizona and New Mexico.

\section{LEUCELENE Greene.}

Low perennials with very leafy stems from a ligneous base. Heads small, solitary and terminal on the simple stems or ultimate branchlets. Involucre broadly turbinate; bracts very unequal, closely imbricated in about 3 unequal series, herbaceous but with hyaline margins. Rays white or reddish. Disk-flowers yellow or reddish (white, acc. to Greene), tubular-funnelform, shortly 5-toothed. Style-tips ovate or oblong, obtuse. Achenes compressed, pubescent. Pappus a single series of scabrous white bristles.

1. L. ericoides (Torr.) Greene, Pitt. iii. 148 (1896). Inula ? ericoides Torr., Ann. Lye. N. Y. ii. 212 (1828). Aster ericaefolius Rothrock, Bot. Gaz. ii. 70 (1877). Erigeron Jacinteus Hall, Univ. Calif. Pub. Botany, i. 127 (1902).

Five to $15 \mathrm{~cm}$. high: stems crowded, simple and monocephalous or cymosely branched, the heads then terminating leafy branchlets: herbage cinereous with a short strigose pubescence: 
leaves 5 to $12 \mathrm{~mm}$. long, the lower spatulate or obovate, the upper varying to linear or nearly filiform: involucre $5 \mathrm{~mm}$. high; bracts lanceolate, acute: rays 12 to 20,5 to $10 \mathrm{~mm}$. long.

Gravelly soil on the summit of Tahquitz Peak, San Jacinto Mts., 2700 m. alt., Hall, no. 2322 ; Providence Mts., May 30, 1902, Brandegee, east to Kansas, south into Mexico. I am indebted to Mrs. Katharine Brandegee for ealling my attention to the identity of Erigeron Jacinteus with this species.

\section{ERIGERON L. Flenbane.}

Herbs, with entire or toothed alternate generally sessile leaves and solitary or cymose or rarely paniculate heterogamous heads. Involucre campanulate or hemispheric; bracts narrow, equal, little imbricated, seldom coriaceous or green-tipped. Receptacle flat or convex, usually naked. Ray-flowers exceedingly numerous, pistillate; ligules white or pink or purple, or in some species wholly wanting. Disk-corollas yellow. Style-appendages (at least in our species) triangular, obtuse to truncate, rarely much exserted. Achenes flattened, usually pubescent and nerved. Pappus more scanty and fragile than in Aster, often with a distinct short outer series.

A.-Rays conspicuous, much surpassing the disk.

Involucre $2 \mathrm{~cm}$. or more wide: leaves over $1.5 \mathrm{~cm}$. wide: submaritime perennial.

1. E. glaucus.

Involuere, and usually also the leaves, much narrower.

Plants low, mostly under $3 \mathrm{dm}$., simple or diffusely branched.

Leaves entire.

Root perennial.

Herbage canescent or silvery with a soft appressed pubescence.

Pappus double: stems stout, silvery-white

2. E. Parishii.

Pappus simple: stems slender, merely canescent

4. E. linearis.

Herbage green or cinereous with a harsh pubescence.

Stems crowded on a thick multicipital caudex: pappus double, the outer series short

3. E. concinnus.

Stems from slender rootstocks: pappus simple.

6. E. sanctarum.

Root annual or biennial: heads loosely cymose..12. E. divergens. Leaves ternately parted

5. E. compositus. 
Plants tall, mostly 3 to $6 \mathrm{dm}$., eymosely branching above.

Leaves linear to filiform: rays about 30 to 40 or 80 .

Involucre pubescent.

Herbage einereous with spreading hairs

7. E. Breweri.

Herbage strigose-pubescent (especially the leaves)

8. E. foliosus.

Involucre glabrous.

9. E. striatus.

Leaves broadly spatulate to oblong or ovate: rays much over 100, pink or white. 10. E. Philadelphicus.

\section{B.-Rays inconspicuous or none.}

Perennials: $3 \mathrm{dm}$. or less high.

Leaves entire: var. aphanactis of

3. E. concinnus.

Leaves trifid: var. discoideus of

5. E. compositus.

Annuals: 3 to $20 \mathrm{dm}$. high (unless depauperate).

Branched from the base: heads long-peduncled: pappus double

11. E. incomptus.

Simple below: heads in diffuse panicles: pappus simple.

Involuere glabrous

13. E. Canadensis.

Involucre pubescent

14. E. linifotius.

1. E. glaucus Ker., Bot. Reg. i. t. 10 (1815). Seaside Daisy.

Flowering stems erect, 1 to $3 \mathrm{dm}$. high, commonly one-headed, arising from a radical tuft of leaves erowning the fleshy caudex and often also from rosulate offsets terminating prostrate woody branches: leaves finely puberulent, stems pilose-pubescent, heads somewhat tomentose: leaves rather succulent, spatulate or obovate, entire, rarely with a small tooth on each side below the apex, 3 to $10 \mathrm{~cm}$. long: upper cauline small and scattered: rays very numerous (60 to 100 or more), rather broad, lilac or violet.

Common on San Miguel Island, ace. to Greene, and plentiful along the seashore further north. Not reported from the mainland of Southern California.

2. E. Parishii Gray, Syn. Fl. i. pt. 2, 212 (1884).

Stems rigid, erect, from a more or less woody base: herbage silvery-white with a soft appressed pubescence: lower leaves narrowly spatulate, 3 to $4 \mathrm{~cm}$. long, less than $5 \mathrm{~mm}$. wide; upper leaves smaller, linear, acute: heads solitary, terminating the branches: involucre 5 to $6 \mathrm{~mm}$. high: rays numerous, linearoblong, $1 \mathrm{~cm}$. long, violet or "purple": achenes hirsute: inner 
pappus-bristles rather numerous, the shorter outer ones conspicuous.

Abundant on stony hillsides at Cushenberry Springs, on the desert base of the San Bernardino Mts., Parish, who only has collected it.

3. E. concinnus (H. \& A.) T. \& G., Fl. ii. 174 (1841). Distasis ? concinna H. \& A., Bot. Beech. 350 (1840).

Stems numerous, erect, from a strong perennial caudex, more or less branched: herbage gray with a long hispid pubescence: leaves linear-spatulate, acute, 2 to $5 \mathrm{~cm}$. long: heads terminating slender peduncles, hemispheric, nearly $1 \mathrm{~cm}$. in diameter: ligules numerous, narrow, 5 to $8 \mathrm{~mm}$. long, violet or blue ur rarely white: outer pappus of conspicuous subulate to oblong paleae.

Providence Mts., Mohave Desert, in the Upper Sonoran Zone, May 26, 1902, Brandegee; Sierra Nevada and Rocky Mts.

Var. aphanactis Gray, Proc. Am. Acad. vi. 540 (1865). $E$. aphanactis Greene, Fl. Fr. 389 (1897). Heads discoid, the ligules being very short or wanting.--San Bernardino Mts., from $1950 \mathrm{~m}$. alt. in the Transition Zone of Bear Valley to $3450 \mathrm{~m}$. alt. in the Alpine Zone of Mt. San Gorgonio; also in Colorado, Nevada, etc. The range of variation in the pappus is as great in the variety as in the species; it cannot therefore be specifically separated, the absence of rays not constituting a specific character. Certain of our specimens, notably those gathered on the summit of Sugarloaf Peak, San Bernardino Mts., by Professor and Mrs. Grinnell, under no. 211, are only 4 or $5 \mathrm{~cm}$. high and with scapose stems leafy only below. In general appearance they seem quite different from the more northern form, but a collection from Nevada by Shockley exhibits intermediate forms.

4. E. linearis (Hook.) Piper, Contr. U.S. Nat. Herb. xi. 567 (1906). Diplopappus linearis Hook., Fl. Bor. Am. ii. 21 (1834). E. filifolius Gray, Syn. Fl. i. pt. 2, 213 (1884); not E. filifolius Nutt., Trans. Am. Philos. Soc. ser. 2, vii. 308 (1841).

Stems rather numerous, slender, 1.5 to $3 \mathrm{dm}$. high from a slender scarcely woody base, usually branched above and bearing several or numerous heads: herbage canescent or cinereous with a fine close pubescence : leaves crowded, all linear-filiform or 
the lower very slightly dilated upward, 3 or $4 \mathrm{~cm}$. long, $1 \mathrm{~mm}$. or less wide: involucre 4 or $5 \mathrm{~mm}$. high : rays 30 to 50 or 80 , purple violet or white, 5 to $10 \mathrm{~mm}$. long: achenes slightly pubescent or glabrate: pappus simple, the bristles fragile.

Providence Mts., Mohave Desert, Brandegee; Nevada and eastern Sierra Nevadas to British Columbia.

5. E. compositus discoideus Gray, Am. Jour. Sci. ser. 2, xxxiii. 237 (1862).

Stems cespitose from a multicipital caudex: herbage hirsute to glabrate: leaves much crowded on the crowns of the caudex, mostly 1 to 3 -ternately parted into linear or short-spatulate lobes: peduncles erect and scape-like, monocephalous, 1 to $10 \mathrm{~cm}$. long, either naked or with a few mostly entire bracts : involucre hemispheric, about $1 \mathrm{~cm}$. broad: rays in this var. none: pappus simple.

Summit of San Gorgonio Peak (Grayback), 3490 m. alt., Jul. 16, 1906, J. and H. W. Grinnell, no. 275; Sierra Nevadas to Greenland. Typical E. compositus Pursh, differs from the var. here described only in having 40 to 60 white-purple or violet rays, these mostly 5 to $7 \mathrm{~mm}$. long. It is to be expected with the var. in Southern California.

6. E. sanctarum Wats., Proc. Am. Acad. xxiv. 83 (1889).

A few $\mathrm{cm}$. to $2 \mathrm{dm}$. high: stems one to several, erect or subdecumbent, from slender perennial rootstocks, leafy below, nearly naked above, monocephalous: herbage minutely rough-pubescent, the involucre densely hispid: leaves entire, $4 \mathrm{~cm}$. or less long, oblanceolate or the small upper ones linear, all acute: involucre hemispheric, 7 to $10 \mathrm{~mm}$. high; its numerous bracts very narrow and acute: rays numerous, narrow, 7 to $10 \mathrm{~mm}$. long, rose-purple: pappus simple, sordid, fragile.

Santa Inez Mts., Santa Barbara Co., 1888, Santa Rosa Island, Jun., 1888, and San Simeon, Jun., 1889, all by Brandegee; La Graciosa, near the boundary between Santa Barbara and San Luis Obispo counties, May 11, 1896, Miss Eastwood.

7. E. Breweri Gray, Proc. Am. Acad. vi. 541 (1865).

Mostly 2 to $6 \mathrm{dm}$. high: stems from slender rootstocks, erect or ascending, leafy up to the terminal cyme: herbage scabrous- 
cinereous with a harsh spreading pubescence: leaves rarely over $2.5 \mathrm{~cm}$. long, narrowly spatulate or linear, obtuse or barely acute: involucre glabrous or granulose-glandular to cinereous, never with appressed hairs, the bracts acute: rays mostly 10 to 20 , violet, 6 to $8 \mathrm{~mm}$. long: pappus essentially simple.

Arid portion of the Sierra Nevada Mts.; Hesperia, Mohave Desert, Parish, no. 3603. Mr. Parish's plant is doubtfully of this species, differing from the typical form mainly in the spreading pubescence of the involucre. More material is needed.

8. E. foliosus Nutt., Trans. Am. Philos. Soc. ser. 2, vii. 309 (1841).

Three to $6 \mathrm{dm}$. high : stems many, from an herbaceous perennial base, erect, simple up to the open cymose inflorescence: herbage roughened with short rigid pustulate incurved hairs, especially on the leaves, or nearly glabrous: leaves rigid, very fragile when dry, linear, 1.5 to $4 \mathrm{~cm}$. long, 2 to 4 or $6 \mathrm{~mm}$. wide, only the upper ones reduced: involucre strigose-pubescent: rays about 30 to 40, violet or purple, 6 to $8 \mathrm{~mm}$. long: achenes linearoblong, the margins thickened, pubescent with spreading setiform hairs: pappus apparently simple but usually with a few short inconspicuous outer bristles.

Common on hills and in the mountains up to $2100 \mathrm{~m}$. alt. throughout California.

Var. stenophyllus (Nutt.) Gray, Bot. Calif. i. 330 (1876). E. stenophyllus Nutt., Pl. Gamb. 176 (1848). E. tenuissimus Greene, Pitt. iii. 25 (1896) ? E. Nuttallii Heller, Bull. Torr. Club xxv. 628 (1898). E. fragilis Greene, Bull. So. Calif. Acad. i. 39 (1902). Differs from the species only in its leaves which are $2 \mathrm{~mm}$. or less wide, often filiform.-A common form, especially in dry exposed places.

Var. tenuissimus Gray, Syn. Fl. i. pt. 2, 215 (1884). $E$. tenuissimus Greene, Pitt. iii. 25 1896? Slender, small-leaved: leaves nearly all filiform, erect or ascending, the longest only 2.5 $\mathrm{cm}$. long; upper ones gradually shorter, becoming setaceous-subulate: heads much smaller.-Along the Mexican border; the type of $E$.tenuissimus Greene from Ventura Co.

Var. Blochmanae (Greene) Hall, comb. nov. E. Blochmanae Greene, Pitt. iii. 25 (1896). Stout: herbage canescent with a 
soft pubescence: heads short-peduncled in a terminal cyme : rays 50 to 60 : achenes glabrous or nearly so.-A seashore form, gathered in northern Santa Barbara Co. by Mrs. Blochman (acc. to Greene) and by Miss Eastwood (no. 784).

9. E. striatus Greene, Bull. So. Calif. Acad. i. 39 (1902).

Three to $9 \mathrm{dm}$. high: stems erect, bright green, striate, cymosely branched at summit: herbage glabrous throughout except the margins of the leaves, these somewhat scabrous: leaves oblong-linear, obtuse, about $4 \mathrm{~cm}$. long: rays numerous, narrow, deep violet: achenes sparsely strigulose or almost glabrous, the margins not prominently thickened: outer pappus of a very few short bristles.

Houston Flat, in the Transition Zone of the San Bernardino Mts., Dr. W. R. Shaw; not seen by me.

\section{E. Philadelphicus L., Sp. Pl. 863 (1753). Skevish.}

Plant biennial or perennial from ereeping rootstocks, 5 to 9 dm. high, branched only toward the summit: herbage short-hispid: leaves spatulate or oblong, serrate or coarsely few-toothed; the radical 10 to $15 \mathrm{~cm}$. long (including the long margined petiole); the cauline smaller, with auriculate-clasping base, passing above into reduced ovate or lanceolate and commonly entire acute leaves of the inflorescence: rays white or pink, filiform, very numerous, about $6 \mathrm{~mm}$. long: pappus simple.

Along streams and in springy places throughout the Upper Sonoran and Lower Transition zones of our district, but not very common; widely distributed.in North America.

11. E. incomptus Gray, Syn. Fl. i. pt. 2, 218 (1884).

Slender, erect, branched from the base, 3 to $7 \mathrm{dm}$. high: herbage somewhat hirsute: leaves narrowly linear or the lower narrowly spatulate, $7 \mathrm{~cm}$. or less long, less than $5 \mathrm{~mm}$. wide, mostly entire: involucre 4 or $5 \mathrm{~mm}$. high: rays minute, bluish or purplish: pappus in two series.

Carysito, Lower California, Orcutt, no. 874; Tia Juana River, San Diego Co., Miss Stokes.

12. E. divergens T. \& G., Fl. ii. 175 (1841).

Stems several or numerous, ascending, from a stout taproot, sometimes decumbent at base: herbage roughened with a short 
hispid pubescence: leaves linear, 1 to $2 \mathrm{~cm}$. long, or the lower somewhat longer and linear-spatulate, the uppermost reduced: heads solitary, terminating slender peduncles: rays numerous, filiform, $6 \mathrm{~mm}$. long, violet or purplish (or white?) : inner pappus of scanty slender bristles, the outer of much shorter subulate squamellae.

Lower California, Brandegee; Laguna, San Diego Co., Cleveland; San Bernardino Mts., where common; Chuckawalla Bench, Colorado Desert, Hall \& Greata, no. 5881; near Palm Springs, Gilman; Swartout Cañon, San Antonio Mts.; north to Washington and east to Nebraska.

13. E. Canadensis L., Sp. Pl. 863 (1753). Leptilon Canadense Britton, Illus. Fl. iii. 391 (1898). HorseweEd.

Stem simple, erect, 6 to $25 \mathrm{dm}$. high: herbage hispid with scattered hairs or nearly glabrous: leaves linear to lanceolate, the lowest spatulate or narrowed to a petiole, 5 to 7 or $8 \mathrm{~cm}$. long, mostly entire but the lower often acutely toothed or lobed: heads small, very numerous in a sometimes dense terminal panicle: involuere $4 \mathrm{~mm}$. high, either perfectly glabrous or the outer bracts sparsely pubescent: ray-flowers numerous, their ligules white, shorter than or scarcely exceeding the pappus: pappus simple.

An indigenous weed, very common in waste places and cultivated fields, flowering in late summer and autumn. Widely distributed in the Old World, where it has become naturalized, and in South America. With us the stems often grow to a height of $25 \mathrm{dm}$. and become $1 \mathrm{~cm}$. in diameter at the base in a single season and much larger specimens are to be expected from the irrigated portions of the Desert Area. The root is rarely biennial.

14. E. linifolius Willd., Spec. iii. 1955 (1810).

Rather strict, 2 to $7 \mathrm{dm}$. high from an annual or biennial root: herbage somewhat hispid, also scabrous with a minute appressed pubescence: leaves narrowly spatulate to linear, 3 to $10 \mathrm{~cm}$. long (the upper gradually shorter), all but the lower entire: heads rather few, in a loose panicle: involucre 4 or $5 \mathrm{~mm}$. high; its bracts linear-subulate, all copiously pubescent: ligules very small, 
shorter than the style and the pappus, white: pappus simple, sordid and becoming ferruginous.

A wayside weed recently introduced from the tropics: San Diego, Jul. 1, 1895, Miss Stokes: Redlands, Sept. 1905, Reed, no. 806, and Greata; Pasadena, Grant, Grinnell, etc. ${ }^{14}$ In all these collections, except the first, the pappus is dull white, but otherwise they agree in every detail with typical $E$. linifolius. It is probable that the pappus colors with age.

\section{CONYZA.}

Herbs, or rarely shrubs, with alternate leaves and rather small heads mostly in eymes or racemes. Bracts of the involucre in two or more rows, often with membranaceous margins. Receptacle naked. Pistillate flowers in two or more outer circles; their corollas slender, dull white or yellowish, much shorter than the style, with notched or obscurely ligulate border. Perfect flowers central, mostly fertile. Achenes small, compressed. Pappus usually a single series of bristles.

1. C. Coulteri Gray, Proc. Am. Acad. vii. 355 (1868).

Two to $10 \mathrm{dm}$. high: stems erect from an annual root, herbaceous and leafy throughout, branching above into an oblong panicle of numerous heads : herbage viscidly pubescent or shorthirsute with many-jointed hairs: leaves thin, the lower oblanceolate in outline (often $1 \mathrm{dm}$. long), the main cauline varying to narrowly oblong and closely sessile by a broad base (2 to $5 \mathrm{~cm}$. long), all thin and coarsely toothed: involucre $3 \mathrm{~mm}$. (whole head about $5 \mathrm{~mm}$.) high; bracts linear-acuminate, the inner ones scarious, the outer obscurely white-margined: pistillate flowers numerous, their nearly white corollas only one-half as long as the style and with obscurely toothed summit: perfect flowers 5 to 8 : achenes elliptic-oblong, minutely pubescent: pappus dull white, soft, much exceeding the involucre.

Lower and Upper Sonoran zones, in moist soil at low altitudes, from the San Joaquin Valley and Southern California to Mexico; rare in our district: Santa Cruz Island, ace. to Greene; ${ }^{15}$ Santa

14 Now reported also from Riverside and Old San Bernardino by Parish, Muhlenbergia iii. 61 (1907).

15 Bull. Calif. Acad. ii. 401 (1887). 
Catalina Island, acc. to MeClatehie;16 near Los Angeles; San Bernardino; Riverside; Temeseal Wash; bottom lands along the Colorado River; etc.

\section{BACCHARIS L.}

Perennials, mostly shrubs but some herbaceous from a woody base, commonly resinous or glutinous, rarely pubescent. Leaves alternate. Heads many-flowered. Involucre imbricated. Flowers whitish or yellowish, dioecious. Staminate flowers with tubular corolla slightly dilated at the throat, the limb cleft into 5 linear lobes; ovary abortive; style present. Corolla of the pistillate flowers very slender and thread-like, obscurely toothed at apex, the teeth erect, not spreading. Pappus in the sterile plant of scanty capillary bristles; in the fertile copious and often very long.

Evergreen shrubs.

Leaves all less than $5 \mathrm{~cm}$. long.

Receptacle naked: pappus of fertile flowers copious, becoming 6 to $12 \mathrm{~mm}$. long.

Leafy up to the glomerate heads with obovate obtuse leaves

... B. pilularis.

Less leafy; the leaves mostly linear or oblong.

Pappus of sterile flowers bearded at tip; of fertile flowers 10 to $12 \mathrm{~mm}$. long.

2. B. Emoryi.

Pappus of sterile flowers naked at tip; of fertile flowers 6 to $8 \mathrm{~mm}$. long.

3. B. sarothroides.

Receptacle chaffy: pappus of fertile flowers scanty, $3 \mathrm{~mm}$. or less long. 4. B. sergiloides.

Leaves 5 to $12 \mathrm{~cm}$. long (except a few upper ones), willow-like.

Cymes terminating main branches: leaves denticulate, 3-nerved: stems herbaceous above ..8. B. glutinosa.

Cymes terminating short lateral branchlets: leaves mostly entire, inconspicuously 3-nerved: stems shrubby throughout.

9. B. viminea.

Herbaceous perennials, the base sometimes woody.

Herbage pubescent: leaves linear.

Leaves very small, entire.

5. B. brachyphylla.

Leaves 2 to $5 \mathrm{~cm}$. long, acutely serrate

6. B. Plummerae.

Herbage glabrous kut resinous: leaves lanceolate. 7. B. Douglasii.

16 Eryth. ii. 125 (1894). 
1. B. pilularis DC., Prodr. v. 407 (1836).

Compactly branched shrub, 1 to $3 \mathrm{~m}$. high or much lower and sometimes prostrate when growing near the sea: branchlets angular: leaves sessile, cuneate-obovate, very obtuse, 1 or $2 \mathrm{~cm}$. long, coarsely or sinuately few-toothed, or occasionally entire: heads solitary or several in the axils or in terminal clusters on the numerous leafy branchlets, short-cylindric or ovoid; involucre $4 \mathrm{~mm}$. high; the outer bracts broadly, the inner narrowly oblong, sometimes denticulate at apex: achenes 10-nerved: pappus of the fertile flowers abundant, becoming $10 \mathrm{~mm}$. long, that of the staminate flowers dilated at apex.

Upper Sonoran Zone: near Santa Monica, Davidson, Hasse, Barber; Port Harford, San Luis Obispo Co., Davy, no. 2715, in part; San Miguel Island, Greene; more plentiful from Monterey to Oregon.

2. B. Emoryi Gray, Bot. Mex. Bound. 83 (1859). B. salicina Gray, Bot: Calif. ii. 456 (1880), in part; not B. salicina T. \& G.

Moderately branched erect shrub, 1 to $4 \mathrm{~m}$. high; branchlets striate-angled: leaves linear to oblong or oblanceolate, obtuse at apex, spatulate or attenuate at base, the larger ones (2 to $4 \mathrm{~cm}$. long) 3-nerved and commonly with several short broad teeth: heads in small glomerules terminating short nearly naked peduncles, the whole inflorescence forming a more or less open panicle: involucre campanulate or oblong, $6 \mathrm{~mm}$. high, closely imbricated; its outer bracts oval, firm, bordered by a narrow scarious minutely ciliate margin; the inner bracts oblong to linear, thin: achenes glabrous, 10-nerved: pappus of the fertile flowers copious, in fruit 10 or $12 \mathrm{~mm}$. long, of the staminate flowers scant and bearded at the tip.

In moist places of Upper and Lower Sonoran zones: Los Angeles; Riverside; San Diego; Colorado Desert; plentiful at Redondo, San Pedro, etc., ace. to Parish; also in Arizona, Nevada, and Utah.

3. B. sarothroides Gray, Proc. Am. Acad. xvii. 211 (1882).

Erect fastigiately much branched shrub, 2 or $3 \mathrm{dm}$. high: twigs striate-angled, very numerous and slender, forming 
crowded broom-like clumps : leaves few, linear, entire, $2 \mathrm{~cm}$. long (or usually much less), not over $5 \mathrm{~mm}$. wide (those of the branchlets sparse and much reduced), 1-nerved: heads mostly solitary on the naked wiry peduncles but these are so numerous that the infllorescence is densely paniculate: involucre campanulate or oblong, barely $5 \mathrm{~mm}$. high, closely imbricated; outer bracts oval, obtuse, very firm; the inner ones thin, narrow, and much elongated: achenes glabrous, 10-nerved: pappus of fertile flowers soft and copious, sordid or reddish, 6 to $8 \mathrm{~mm}$. long; of the staminate flowers scant, slightly dilated at tip but not bearded.

Southwestern San Diego Co., Arizona, and Mexico: therefore to be expected anywhere along our southern border: plentiful in dry soil from Mission Valley, near San Diego, and the Sweetwater dam to the Mexican line.

4. B. sergiloides Gray, Bot. Mex. Bound. 83 (1859).

Erect glabrous shrub, 1 or $2 \mathrm{~m}$. high, with many broom-like branches : twigs green, strongly striate-angled, either nearly leafless or the sterile shoots leafy : leaves entire or rarely few-toothed, linear to spatulate or obovate, usually small and sparse but sometimes numerous and as much as $4 \mathrm{~cm}$. long by $2 \mathrm{~cm}$. broad on sterile shoots : inflorescence densely paniculate; heads solitary on the short bractless peduncles: involucre about $5 \mathrm{~mm}$. high, its bracts firm: receptacle either flat or conical, bearing few or numerous chaffy bracts among the flowers similar to the inner bracts of the involucre: achenes 10-nerved: pappus rather rigid and scanty, not elongated in age, of the fertile flowers even in fruit not surpassing the style and barely twice the length of the mature achene.

Lower Sonoran Zone, in dry creek-beds, etc., from the east base of San Jacinto Mt. and San Felipe Creek across the Colorado and Mohave deserts to Nevada and Utah: Banner, San Diego Co., Apr., 1901, Brandegee; Chuckawalla Bench, Riverside Co., Oct. 9, 1904, Schellenger, no. 6 (nearly leafless) : Providence Mts., May 25, 1902, Brandegee (very leafy). In the Panamint Mts. this species is restricted to the vicinity of the small streams occupying the bottoms of the steep narrow cañons, and for this reason is known to miners as the "Desert Willow." 
5. B. brachyphylla Gray, Pl. Wright. ii. 83 (1853).

Diffusely much branched, 6 to $10 \mathrm{dm}$. high: stems slender, woody at base : herbage scabro-puberulent or smooth : leaves mostly linear, entire, $1.5 \mathrm{~cm}$. or less long, those on the branchlets much reduced and scale-like: involucre 4 or $5 \mathrm{~mm}$. high, 12 to 15 flowered, somewhat canescent; bracts oblong-lanceolate or broader, acute, with greenish back and scarious margins: achenes 4 or 5-nerved: pappus scant, rigid, in fruit $6 \mathrm{~mm}$. long, sordid.

Southern San Diego Co. to Arizona: Larkins Station, Palmer, no. 149 ; Bradshaw Mts., Arizona, Purpus, no. 8502; San Bernardino Co., acc. to Gray, but there was probably an error in the label since recent collectors have not found it north of San Diego Co.

6. B. Plummerae Gray, Proc. Am. Acad. xv. 48 (1879).

Herbaceous from a woody base, $1 \mathrm{~m}$. high (in our specimens), the stems slender and loosely branched: herbage viscidly pubescent, especially the inflorescence: leaves linear or narrowly oblong, obtuse, narrowed to the base, 2 to $5 \mathrm{~cm}$. long, sharply serrate : heads few, paniculate or cymose at the ends of the branches : involucre 5 to $7 \mathrm{~mm}$. high; bracts linear, acute, with a green midrib and scarious margins: achenes pubescent, obscurely 5nerved: pappus scanty, rigid, in fruit $8 \mathrm{~mm}$. long.

Upper Sonoran Zone, in cañons near the sea : near Santa Barbara, 1876, J. G. Lemmon and wife (Mrs. Sarah Plummer Lemmon, for whom the species is named) ; near Santa Monica, Parish, no. 1110; Topango, Barber ; Santa Cruz Island, ace. to Greene. ${ }^{17}$

7. B. Douglasii DC., Prodr. v. 400 (1836).

Herbaceous nearly or quite to the base, $18 \mathrm{dm}$. or less high: stems simple up to the terminal cyme or with a few simple ascending branches : herbage very glutinous : leaves lanceolate, attenuate above, tapering below to a short petiole, 3-nerved from the base, 6 to $12 \mathrm{~cm}$. long, the upper reduced, serrulate or entire: heads numerous in a terminal compound almost naked cyme; involucral bracts linear or lanceolate-linear with greenish center, the scarious margins erose-ciliate: receptacle broadly conical : achenes 5 nerved, pubescent: pappus of fertile flowers short and soft, of the sterile ones clavellate at summit.

17 Bull. Calif. Acad. ii. 401 (1887). 
In damp soil along streams or in thickets of the Upper Sonoran Zone from San Diego Co. to middle California; only occasional with us.

8. B. glutinosa Pers., Syn. ii. 425 (1807).

Shrubby, at least below, 1 to $3 \mathrm{~m}$. high, the slender leafy stems usually simple above and flowering only at the summit: herbage glutinous: leaves lanceolate, acute at each end, remotely but saliently denticulate (or rarely entire), 5 to $10 \mathrm{~cm}$. long, 3-nerved from the base: heads in terminal cymes or panicles: involucre and receptacle as in $B$. viminea: pappus of fertile flowers more or less scabrous.

On moist ground in the Upper and Lower Sonoran zones from Butte Co. to San Diego, east and south to Colorado and Mexico; also in Chile: Ballona marshes, Los Angeles Co., Chandler, no. 2030; Santa Ana River, near Riverside, Koethen: Imperial, Colorado Desert, Wales, no. 18; Banning, Parish, no. 726; Owens Valley, Inyo Co., Austin.

9. B. viminea DC., Prodr. v. 400 (1836). B. caerulescens DC., I. c. 402. Mule Fat. Guatemote.

Distinctly shrubby and willow-like, 2 to $4 \mathrm{~m}$. high, the very leafy stems producing usually numerous short lateral flowering branches, these striate-angled: herbage scarcely glutinous : leaves narrowly lanceolate, acute at each end, entire or sparingly denticulate, 3 to $10 \mathrm{~cm}$. long, inconspicuously or not at all 3-nerved: heads rather numerous in terminal and lateral cymes: involucre $5 \mathrm{~mm}$. high; bracts chartaceous, oblong or the outer ones ovate, destitute of greenish center, with scarious margins, erose and mostly villous-ciliate: receptacle flat: pappus of fertile flowers apparently smooth but minutely scabrous as seen under the microscope.

Lower and Upper Sonoran zones; common along ditches and in waste places, especially. on low damp ground, often forming dense thickets; Riverside and San Bernardino to the Sacramento Valley and from the desert to the coast. 


\section{Tribe 3. inUleaE. Everlasting Tribe.}

\section{PLUCheA. Cass.}

Tall leafy herbs or shrubs. Heads numerous, clustered in corymb-like terminal cymes, hemispheric, discoid, the numerous flowers purplish. Marginal flowers of the head pistillate and perfect, with tubular-filiform truncate entire or 2 or 3-toothed corolla and slender 2-cleft style; central flowers few, perfect, but sometimes sterile, with tubular 5-cleft corolla (enlarged above) and trifid or merely notched style. Involucre imbricated. Receptacle flat, naked. Achenes grooved. Pappus a single series of eapillary bristles.

The genus Pluchea is here made to include two plants which are very different in general appearance but which represent two extremes of a genus in which the species are well united by technical characters. Some botanists have attempted to force our second species into the South American genus Tessaria, which disposition of it is apparently favored by Hoffman, ${ }^{18}$ who gives as the range of that genus "Argentine to California.". Since no other species of Tessaria ranges near California he probably had T. borealis in mind. But Hoffmann distinguishes Tessaria from Pluchea largely by the fewer (one to ten) hermaphrodite flowers. Now, $P$. borealis often has, in California, at least, as high as twenty hermaphrodite flowers, while in P. camphorataa geuine Pluchea-they are sometimes reduced to twelve. Since also the involucral bracts in the two genera are quite similar it is necessary, if both genera are to be retained, to fall back on other characters, among which those proposed by Gray ${ }^{19}$ may be useful, namely, "the narrow heads and the long villosity of the small receptacle" in Tessaria. This would restrict Tessaria to South America and leave our second species in Pluchea, where it undoubtedly belongs, unless a new genus based on habital characters alone be erected for it.

Herb: glandular-pubescent.

1. P. camphorata.

Shrub: herbage silvery with a close dense pubescence. 2. P. sericea.

18 Hoffmann, in Engler \& Prantl, Natürl. Pflanzenf. iv. abt. 5, 177 (1890).

19 Proc. Am. Acad. xvii. 212 (1882). 
1. P. camphorata (L.) DC., Prodr. v. 452 (1836). Erigeron camphoratus L., Sp. Pl. ed. 2, 1212 (1763). SAlt-Marsh FleaBANE.

An erect annual, branching above, 3 to $8 \mathrm{dm}$. high (sometimes even 4 or $5 \mathrm{~m}$. high, when growing near saline springs in the desert): herbage soft-puberulent, glandular above: leares oblong-ovate or lanceolate, acute at each end, glandular-dentate, short-petioled or the upper sessile, the larger 7 to $14 \mathrm{~cm}$. long and 2 or $3 \mathrm{~cm}$. wide: involucral bracts chartaceous, ovatelanceolate, commonly reddish: central hermaphrodite flowers varying from 10 or 12 to numerous : achenes pubescent: pappusbristles all slender, not at all dilated above.

In moist, saline soil from San Diego Co., Santa Catalina Island, and the Colorado Desert (Dos Palmas, etc.), north; also in Arizona and Texas and along the Atlantic seaboard; especially common in salt-marshes near the coast.

2. P. sericea (Nutt.) Coville, Contr. U. S. Nat. Herb. iv. 128 (1893). Polypappus sericeus Nutt., Pl. Gamb. 178 (1848). T'essaria borealis Gray, Pl. Wright. i. 102 (1852). Pluchea borealis Gray, Proc. Am: Acad. xvii. 212 (1882). ARRow-WEED.

Slender willow-like shrub 2 to $5 \mathrm{~m}$. high (or in depauperate plants much smaller): herbage silvery-silky throughout except on the old stems: leaves alternate, entire, linear-lanceolate, 1 to $3.6 \mathrm{~cm}$. long, 3 to $6 \mathrm{~mm}$. wide, acute at apex, tapering to the sessile base: outer involucral bracts brown or purplish, firmcoriaceous, the white inner ones much thinner: style-branches of the pistillate flowers slender, long-exserted at maturity: central hermaphrodite flowers 20 or less, their pappus-bristles slightly dilated at tip.

Fairly common west of the mountains from the northern boundary of Santa Barbara Co. (Cuyama River) and Santa Catalina Island to San Diego; very common in suitable localities on the Colorado Desert; less common on the Mohave Desert (Death Valley, acc. to Coville; Needles; etc.); east to the Rio Grande. A specimen gathered by Dr. Davidson on Wilsons Peak illustrates the effect of unfavorable environment, being nearly simple and only $45 \mathrm{~cm}$. high, but the flowers of the four well developed heads are perfectly normal. 
The Arrow-weed inhabits the borders of springs, ditches, and streams and frequents washes and river-bottoms, often forming impenetrable thickets. The long straight stems furnish valuable materials to the Indians for the making of arrows, while the plants are used on the desert both by Indians and white settlers for thatch in building small dwellings, sun-shades, ete.

\section{MICROPUS L.}

Slender erect floccose-woolly annuals with entire leaves and clustered several-flowered heads. Involucre of a few open searious bracts surrounding the flower-bearing bracts of the receptacle. Receptacular bracts woolly, conduplicate, each enclosing a fertile pistillate flower only the corolla-tube and style of which are exserted through a lateral slit in the sac-like bract. Perfect flowers in the center sterile and mostly naked. Achenes gibbous, the corolla and style borne laterally, remaining enclosed in the cucullate bracts which finally fall away from the receptacle. Pappus commonly none.

1. M. Californicus F. \& M., Ind. Sem. Petrop. 1835, 42. Gnaphalodes Californica Greene, Man. Bot. Reg. S. F. Bay 183 (1894).

Stem erect, .5 to 2 or $3 \mathrm{dm}$. high, commonly branched only toward the summit: leaves linear-oblong, acuminate: receptacle low, with several scale-like processes: fruit-bearing bracts 4 to 6 , semiobovate, tipped with a scarious appendage, at length indurated; the surrounding bracts of the involucre commonly 5, orbicular or ovate, scarious, with a green spot in the center: sterile flowers about 3, the corolla filiform but expanding somewhat toward the throat: 'pappus none.

Frequent on plains and in the foothills and mountains up to about $1500 \mathrm{~m}$. from Southern San Diego Co. to Oregon; not reported from east of the San Jacinto and San Bernardino Mts.

\section{STYLOCLINE Nutt.}

Low erect or spreading woolly annuals with small ovoid or nearly globular clustered heads. Receptacle column-like or almost filiform, bearing at its tip, and therefore in the center of 
the head, 4 or 5 sterile hermaphrodite flowers, each of these enmmonly subtended by a plane or slightly concave bract. Pistillate flowers marginal, each completely enfolded by the medial or (in one species) the basal portion of its very woolly subtending bract. Pappus none in the fertile flowers, sometimes of a few caducous bristles in the sterile ones.

Bracts of the sterile flowers inconspicuous, merely acute: fertile flowers numerous.

Pistillate flowers enclosed in the central portion of wholly hyaline bracts, the margins of which are wing-like

1. S. gnaphalioides.

Pistillate flowers enfolded by the entire basal portion of the bracts, the margins not wing-like. 2. S. micropoides.

Bracts of the sterile flowers tapering into conspicuous rigid hooked cusps: fertile flowers 5 to 9 . 3. S. filaginea.

1. S. gnaphalioides Nutt., Trans. Am. Philos. Soc. ser. 2, vii. 338 (1841).

Diffusely branched from the base, eommonly 5 to $15 \mathrm{~cm}$. long: leaves broadly linear or spatulate-linear; the upper somewhat broader ones, obtuse and 5 to $12 \mathrm{~mm}$. long: pistillate fertile flowers numerous; their bracts (barely $3 \mathrm{~mm}$. long) ovate, nearly plane on the outer surface, a central portion at the base produced on the inner side into a sac enclosing the achene, this portion firm, the remainder hyaline: sterile flowers little shorter than their bracts, with rudimentary ovary and a pappus of few caducous bristles.

On the plains and in dry sandy creek-beds : from San Diego and Santa Catalina Island ${ }^{20}$ to middle California and the borders of the deserts.

2. S. micropoides Gray, Pl. Wright. ii. 84 (1853).

Plant low, beginning to blossom when only a few $\mathrm{cm}$. high : cauline leaves linear, those involucrate to the heads lanceolatelinear, rather acute, .5 to $1 \mathrm{~cm}$. long: pistillate fertile flowers numerous, their very woolly bracts oblong, without hyaline margins or wings, but ending above in a small oblong-ovate hyaline tip, the whole body enwrapping the achene: sterile flowers naked or barely subtended by oblong glabrous paleae, with abortive ovaries and a pappus of 3 or 4 slender and smooth caducous bristles.

20 Acc. to Lyon, Bot. Gaz. xi. 333 (1886). 
In moist sand-washes of the Lower Sonoran Zone: Palm Springs, on the Colorado Desert, Parish, no. 1657, in part; Paloverde Valley, near the Colorado River, Hall; Inyo Co., Brandegee; east to Mexico and New Mexico.

3. S. filaginea Gray, Proc. Am. Acad. viii. 652 (1873). Ancistrocarphus filagineus Gray, l. c. vii. 356 (1868).

Plant 5 to $12 \mathrm{~cm}$. high, variable as to habit, the stem sometimes simple below and cymosely branched above, sometimes simple throughout with a single terminal cluster of heads, but more commonly branched from the base and the branches erect: cauline leaves narrowly linear to spatulate, about $1 \mathrm{~cm}$. (.5 to 2 $\mathrm{cm}$.) long, those involucrate to the heads much broader : pistillate fertile flowers 5 to 9 ; their enfolding bracts (barely $3 \mathrm{~mm}$. long) boat-shaped, firm except at the hyaline tip, smaller than the 5 empty bracts which surround the sterile flowers in the center: empty bracts (4 or $5 \mathrm{~mm}$. long) somewhat coriaceous, tapering into a rigid incurved hooked cusp, persistent and at length stellately spreading: sterile flowers without pappus.

Mohave Desert, Parry, Lemmon, ace. to Gray; dessicated pool, Mohave Desert side of Cajon Pass, May, 1882, Parish; Caliente, Kern Co., Brandegee; near Paso Robles, San Luis Obispo Co., Apr., 1899, Barber; thence to Oregon. Mr. Parish suggests that its presence near Cajon Pass may be due to sheep, for which the pass was long a much traveled highway, and that the Parry and Lemmon specimens probably eame from this same station. This occurrence of the species out of its proper range would thus be explained. Very different in appearance from S. gnaphalioides. Ir that species the large rounded heads are rendered conspicuous by the tawny white-woolly hyaline bracts of the fertile flowers. In S. filaginea the most conspicuous organs of the small heads are the rigid bracts of the central sterile flowers, with their slender incurved tips.

\section{PSILOCARPHUS Nutt.}

Depressed or prostrate white-woolly annuals. Leaves opposite, entire, the uppermost ones involucrate around the small globose heads which lack a true involucre and are solitary in the 
forks or at the ends of the branches, or some clustered. Receptacle globose. Bracts of the pistillate flowers clothed with soft wool, crowded on the low receptacle; each bract sac-like, halfobovate in side view, hooded and rounded at the top with the apex introrse (turned downward and inward) and beaked by a hyaline appendage or scale. Pistillate fertile flowers with filiform corolla. Hermaphrodite-sterile flowers few, occupying the center of the head, destitute of enclosing or other bracts. Achenes straight or slightly curved. Pappus none.

The following disposition of our species is only tentative. Further studies in the field, a comparison with the types, and a knowledge of the Chilean forms, will be necessary before a final revision can be made.

Herbage loosely lanate: heads not numerous. 1. P. globiferus. Herbage canescent with appressed wool: heads numerous. 2. P. tenellus.

1. P. globiferus (Bert.) Nutt., Trans. Am. Philos. Soc. ser. 2. vii. 340 (1841). Micropus globiferus Bert., in DC., Prodr. v. 460 (1836)? Bezanilla Chilensis Remy, in Gay, Fl. Chil. iv. 110, phanerog. t. 46 (1849) ?

Plant simple-stemmed and erect, or freely branched and the branches prostrate or ascending: herbage loosely lanate: leaves broadly linear, those involucrate to the heads oblong, $3 \mathrm{~cm}$. or less long, obtuse: heads mostly terminal, rendered inconspicuous by the whorled upper leaves: achenes elliptic-oblong.

Heavy soil on mesas near San Diego, Abrams, no. 3453, and Brandegee (collection of 1903, not the plant distributed as $P$. globiferus by Baker under no. 1649, which is Stylocline gnaphalioides, correctly determined by Brandegee); Bear Valley, San Bernardino Mts., Parish, no. 3723; common in the vicinity of Los Angeles, acc. to Abrams.

2. P. tenellus Nutt., Trans. Am. Philos. Soc. ser. 2, vii. 341 (1841).

Usually depressed, the forking stems prostrate or ascending and often forming a dense mat 1 to $3 \mathrm{dm}$. broad: herbage canescent with a fine and closely appressed wool; leaves numerous, spatulate or linear, mucronate, .5 to $1.5 \mathrm{~cm}$. long: heads in all the upper leaf-axils, about $4 \mathrm{~mm}$. wide: achenes oblong or slightly broadened upward. 
Near Glendale, Los Angeles Co., Braunton; near Santa Barbara, acc. to Nuttall; Santa Catalina Island, Mrs. Trask; sandhills near Santa Maria, Santa Barbara Co., Miss Eastwood, no. 373 ; Arroyo Grande, San Luis Obispo Co., Brewer, no. 453 ; north to Washington.

\section{EVAX. Gaertn.}

Low but rigid densely woolly annuals with small heads mostly surrounded by a circle of bract-like leaves. Receptacle nearly flat (§Diaperia) or columnar from a broad base (\$Hesperevax). Pistillate fertile flowers numerous, each subtended by a plane or slightly concave scarious oblong bract. Hermaphroditesterile flowers few, central, subtended (in our species) by open scarious bracts. Achenes smooth or minutely papillose, obcompressed. Pappus none.

Leaves narrowed to a slender petiole: receptacle columnar....1. E. sparsiflora. Leaves elosely sessile: receptacle nearly flat. 2. E. multicaulis.

1. E. sparsiflora (Gray) Jepson, Fl. W. Mid. Calif. 549 (1901). E. caulescens sparsiflora Gray, Syn. Fl. l. pt. 2, 229 (1884). Hesperevax sparsiflora Greene, Fl. Fr. 402 (1897).

Erect, 2 to $10 \mathrm{~cm}$. high, the stems branching from the base or rarely simple: leaves spatulate, narrowed to a very slender petiole, the whole leaf 1 or $2 \mathrm{~cm}$. long, 3 or $4 \mathrm{~mm}$. wide in the upper portion: heads solitary in the axils or slightly glomerate at the ends of the branches: bracts of the oblong involucre ( 5 $\mathrm{mm}$. high) and of the fertile flowers woolly externally and longhirsute at base, persistent and becoming coriaceous: receptacle columnar: sterile staminate flowers usually 4 or 5 ; their bracts roundish and tomentulose, whorled near the summit of the receptacle.

San Diego, Cleveland, acc. to Gray; San Luis Obispo, Brewer, no. 464; middle California.

2. E. multicaulis DC., Prodr. v. 459 (1836).

Diffusely branched from the base; the leafy ascending branches sometimes $1.5 \mathrm{dm}$. long, bearing small terminal glomerules which are nearly hidden by the bract-like upper leaves: leaves broadly spatulate, sessile by a broad base, .6 to $1.2 \mathrm{~cm}$. long; about 2 to $5 \mathrm{~mm}$. wide: receptacle depressed-hemispheric: bracts 
of the fertile flowers woolly toward the apex, glabrous toward the more or less narrowed base: bracts of the staminate flowers spatulate, woolly on the back.

Mohave Desert, Lemmon, ace. to Gray; east to Texas.

\section{FILAGO L.}

Low woolly annuals with more or less glomerate small heads. Receptacle hemispherical or conical. Fertile pistillate flowers in two sets, the outer set separated from the inner by a circle of open scarious or chaff-like nearly glabrous bracts; flowers of the outer set, which is borne on the margin of the receptacle, commonly destitute of pappus, each loosely enfolded by a concave or boat-shaped long-woolly bract: flowers of the inner set provided with a pappus of copious eapillary bristles, not enfolded . by bracts. Hermaphrodite flowers in the center of the head few, often fertile, their pappus abundant. Achenes terete or nearly so, either smooth or minutely granular.

Plant erect: bracts of the inflorescence scarcely longer than the heads.

..1. F. Californica.

Plant depressed and spreading: bracts of the inflorescence short, obtuse....

2. F. depressa.

Plant erect or spreading: bracts of the inflorescence linear, elongated, several times longer than the heads.

3. F. Arizonica.

1. F. Californica Nutt., Trans. Am. Philos. Soc. ser. 2, vii. 405 (1841).

Plant or its branches erect, .5 to 2 (or sometimes 4 ) dm. high, leafy throughout: leaves .8 to $2 \mathrm{~cm}$. long, narrowly oblong to linear or somewhat spatulate, sessile, commonly apiculate at apex: heads ovate, 3 or $4 \mathrm{~mm}$. high, scarcely exceeded by the bracts of the inflorescence; receptacle convex, rough: bracts of the outer pistillate flowers 8 to 10 , very woolly, deeply boatshaped and somewhat incurved at the broad and obtuse hyaline tip; bracts of the inner series thin and less woolly, plane or merely concave; all stellately spreading at maturity: marginal achenes smooth; central achenes either smooth or dotted with shining papillae.

Common in dry open places of the Cismontane Area from Guadalupe Island and Ensenada, Sonora, north throughout the state, and ascending the mountains to $2200 \mathrm{~m}$., acc. to Parish; 
also collected in the typical form at Palm Cañon and to be expected elsewhere in the Desert Area, since it occurs in Utah.

2. F. depressa Gray, Proc. Am. Acad. xix. 3 (1883).

Plant branching from the base, the short branches depressed and spreading, or ascending, $1 \mathrm{dm}$. or less high (depauperate plants sometimes simple-stemmed and erect): leaves as in $F$. Californica but smaller : heads about $3 \mathrm{~mm}$. high, borne in small clusters which nearly equal or exceed the shortened upper internodes and are surrounded by short and obtuse bracts of the inflorescence: marginal pistillate flowers 5 or 6 , their woolly enclosing bracts nearly straight: marginal achenes obovate, smooth and shining; inner achenes oblong or fusifurm, smooth.

The type locality is Palm Springs, Colorado Desert, where first collected by Parry, acc. to Gray, then by Parish; and Wright's no. 1819, labeled merely "in damp places, Colorado Desert," was probably gathered here; Colorado Desert in Imperial Co., Brandegee. I have collected the species in Marshall Cañon (no. 5801) and near the Pinto Mts. (no. 6021), both on the Colorado Desert, and near Daggett (no. 6150), on the Mohave Desert, whence it ranges north to Keeler, Inyo Co. (Brandegee). It nearly always grows in dry sandy soil and appears to be restricted to the Lower Sonoran Zone.

3. F. Arizonica Gray, Proc. Am. Acad. viii. 652 (1873).

Plant diffuse or at first erect, with widely spreading branches : leaves short, linear, the upper ones involucrate around and much exceeding the glomerules, which are widely separated by the elongated filiform internodes: marginal pistillate flowers 10 to 15 ; their bracts of firm texture, ovate, open on the face: "achenes clavate-oblong and arcuate, very smooth."

Mohave Desert, Mrs. Brandegee; Santa Catalina Island, ace. to Lyon, ${ }^{21}$ Mrs. Trask; San Diego Co. and south, ace. to Gray; Arizona.

\section{ANTENNARIA Gaertn.}

Low woolly perennial herbs. Leaves mostly in crowded basal tufts, the cauline ones alternate and sessile. Heads dioecious, many-flowered, solitary or terminally cymose (paniculate in one

21 Bot. Gaz. xi. 333 (1886). 
extra-Californian species. Receptacle convex, not chaffy. Involucral bracts scarious, imbricated. Staminate flowers with filiform corolla, entire or merely notched style, and a pappus of rather scant bristles which are barbellate or plumose at the tip and thus apparently thickened. Pistillate flowers with abundant pappus of fine filiform bristles commonly united at base, and falling away in a ring.

Heads solitary, terminating short stems or sessile among the basal leaves: pappus-bristles of sterile flowers hardly thickened at apex

1. A. dimorpha.

Heads in cymose clusters terminating short or elongated stems: pappusbristles of sterile flowers with thick or dilated tips.

Tips of involucral bracts green to pale brown. 2. A. media.

Tips of involucral bracts rose-pink or white.

Leaves permanently hoary on both faces. Leaves green above.

3. A. speciosa. 4. A. marginata.

1. A. dimorpha (Nutt.) T. \& G., Fl. ii. 431 (1843). Gnaphalium dimorphum Nutt., Trans. Am. Philos. Soc. ser. 2, vii. 405 (1841).

Depressed, cespitose, the stout caudex much branched and bearing rosulate clusters of narrowly spatulate leaves which are tomentose on both sides: heads solitary, subsessile at the crown or terminating branches $4 \mathrm{~cm}$. or less long: involucre of the staminate heads about $6 \mathrm{~mm}$. high, of the pistillate heads enlarging to 1 or $2 \mathrm{~cm}$., the former with brownish or bluish obtuse bracts, the latter with often paler bracts, the innermost of which are narrow and attenuate into a hyaline tip.

On dry stony slopes in the mountains: Bear Valley, San Bernardino Mts., Parish; Lytle Creek, San Antonio Mts.; summit of Mt. Pinos, Ventura Co.; thence to British Columbia, Montana, etc.

2. A. media Greene, Pitt. iii. 286 (1898).

Densely cespitose, $1 \mathrm{dm}$. or less (usually 4 or $5 \mathrm{~cm}$.) high including the flowering stems: herbage tomentose throughout: leaves narrowly oblanceolate or spatulate, acute, .4 to .8 (rarely $1.2) \mathrm{cm}$. long: involucre about $4 \mathrm{~mm}$. high; bracts obtuse, green or greenish-brown with lighter tips, those of the pistillate heads ablong or linear-oblong, of the staminate heads oval. 
Summit of Mt. Grayback, $3500 \mathrm{~m}$. alt., in the Alpine Zone, Wright, Blasdale, Mrs. C. M. Wilder; common in the High Sierras and Rocky Mts.

3. A. speciosa E. Nelson, Proc. U. S. Nat. Mus. xxiii. 705 (1901).

Cespitose, with many short sterile shoots forming a leafy mat from which arise the flower-bearing stems, these .7 to $2 \mathrm{dm}$. high and terminating in a single rounded cluster of showy heads: herbage tomentose throughout: leaves spatulate, the cauline varying to linear, 1 to $2 \mathrm{~cm}$. long, $5 \mathrm{~mm}$. or less wide: involucre of pistillate heads fully $6 \mathrm{~mm}$. high, closely imbricated; its outer bracts narrowly oblong, obtuse; the inner ones linear, acute, all with rosy or nearly white tips : staminate plant unknown.

First collected in Bear Valley, San Bernardino Mts., by Parish; Dry Lake, Mt. San Gorgonio, in the same range; very plentiful at a few places in Tahquitz and Tamarack valleys, San Jacinto Mt. It belongs to the upper edge of the Transition Zone.

4. A. marginata Greene, Pitt. iii. 290 (1898).

Cespitose, with many short sterile leafy shoots, the flowering stems from a few $\mathrm{cm}$. to $2 \mathrm{dm}$. high and bearing a single terminal cluster of pale-colored heads: herbage hoary-tomentose, except that the upper surface of the leaves is green and glabrous or only lightly pubescent: basal leaves spatulate, obtuse, mucronate, commonly 1.5 to $2 \mathrm{~cm}$. long and $6 \mathrm{~mm}$. broad; leaves of the flowering stems few, linear, sessile: heads few, the lower ones short-pedunculate, the upper sessile: involucre of pistillate heads broadly campanulate, $8 \mathrm{~mm}$. broad and high (in California plants), conspicuously imbricated; its bracts with a greenish tinge but the conspicuous membranous tips pure white, the long inner ones very narrow and acute.

San Bernardino Mt., on the "trail to South Fork Santa Ana River via Barton Flats, elevation 7200 ft.," Mrs. Wilder, no. 489; near Flagstaff, Arizona, Wilson, no. 115. Heretofore known only from New Mexico and Colorado. 


\section{GNAPhalium L. Cudweed. Everlasting.}

Woolly herbs with sessile and eommonly decurrent leaves. Heads white, yellowish, or rose-tinted, disposed in panicles, cymes, or spikes. Receptacle flat or convex, not chaffy. Involucral bracts searious, imbricated. Pistillate flowers in several series, with filiform corollas. Central flowers hermaphroditefertile, with tubular 5-lobed corollas and entire obtuse styles. Pappus a single series of capillary bristles.

Pappus-bristles united at base, falling away in a ring: inflorescence spikelike: low herb. 1. G. purpureum.

Pappus-bristles not united at base, falling separately.

Involucre imbedded in loose wool, its inconspicuous bracts brown except at the scarious tips: low branching annual. 2. G. palustre.

Involucre woolly only at base, its bracts scarious.

Herbage in age becoming green (at least the upper surface of the leaves), somewhat glandular.

Root perennial: stems woody below

3. G. bicolor.

Root annual or biennial: stems herbaceous throughout.

Inflorescence cymose: involucre broad; bracts white: var. Californicum of

4. G. decurrens.

Inflorescence paniculate: involucre narrow; bracts rose-color or white

5. G. ramosissimum.

Herbage persistently white-woolly throughout, scarcely glandular.

Involucre bright white: heads in loose panicles

6. G. microcephalum.

Involucre greenish-yellow or rusty: heads in close glomerules

..7. G. Chilense.

1. G. purpureum L., Sp. Pl. 854 (1753). Purple Cudweed.

Root perennial : stems commonly several, simple, from an erect or slightly decumbent base, 1 to $3 \mathrm{dm}$. high : herbage canescent with a close dense coating of white wool, the upper surface of the leaves usually early glabrate: leaves broadly spatulate, obtuse, 2 to $5 \mathrm{~cm}$. long and 3 to $12 \mathrm{~mm}$. wide: heads crowded in a spikelike inflorescence which is dense and oblong, or rarely more elongated and more or less interrupted: involucre about $5 \mathrm{~mm}$. high, brownish or purplish: achenes sparsely scabrous:

In saline and alkaline soil: San Diego, Cleveland; Claremont, Shaw; near Santa Barbara and on Santa Rosa Island, Brandegee. 
Common on low open ground near the coast of middle California. Also on the Atlantic coast of North America and in Mexico and South America.

2. G. palustre Nutt., Trans. Am. Philos. Soc. ser. 2, vii. 403 (1841): Lowland Cudweed.

Plant .5 to 1.5 or $2 \mathrm{dm}$. high: stems commonly several and erect or ascending from an annual root: herbage loosely floceose with long wool, sometimes partially deciduous: leaves nearly all spatulate, or a few about the inflorescence oblong or lanceolate, 1 to $3 \mathrm{~cm}$. long: heads in small dense clusters at the ends of the branches : involucre barely $4 \mathrm{~mm}$. high; its bracts linear, brownish or greenish at base, the pearly-white obtuse tips sometimes denticulate: achenes either smooth or scabrous.

Occasional in moist places, especially on margins of ponds or slow-flowing streams, from near the coast to $2500 \mathrm{~m}$. alt. in the mountains; San Diego Co. to Washington and Wyoming.

3. G. bicolor Bioletti, Eryth. i. 16 (1893).

Stout, 6 to $9 \mathrm{dm}$. high, from a perennial root: stems branching and lignescent below, terminating above in a compact cyme or branching to form a more or less open panicle, the branches of which are terminated by close cymes: herbage glandular, whitened by a very thick dense tomentum, which is deciduous only from the upper surface of the leaves: leaves oblong, or linear, or the upper lanceolate, closely sessile by a broad auriculate base, 2 to 5 or $8 \mathrm{~cm}$. long, .5 to 1 (or the lower even 1.5) $\mathrm{cm}$. wide, the margins commonly undulate and revolute: involucre campanulate, $6 \mathrm{~mm}$. high and broad; its bracts white, becoming sordid, at least the inner often with a greenish tinge; the outer ones ovate and obtuse, the inner varying to narrowly oblong and acute.

In the foothills and along the coast, from Lower California to the Kaweah River and Monterey Co.; common on low chaparral-covered hills of the Upper Sonoran Zone in the southern part of its range. I have examined the following specimens, many of which were distributed as other species, some even as Anaphalis margaritacea: San Diego, Mar. 25, 1891, G. W. Dunn (Univ. Calif. no. 31964) ; Botanic Garden, Berkeley, Sept., 1892, Greene (Univ. Calif. no. 31962) $;^{22}$ vicinity of San Diego, Wright:

22 The first two specimens cited are presumably the ones from which the original description was drawn. 


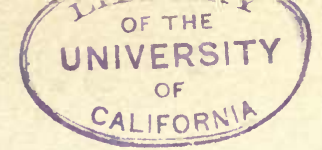

no. 121, also 1885, Greene, Feb. 14, 1891,Miss Eastwood, and Mar., 1906, Mrs. Brandegee; Todos Santos Island, Anthony, no. 205; San Miguel Island, 1903, Beck; San Martin Island, Barkelew, no. 148; San Sebastian, Apr., 1889, and Saucito, Oct., 1893 (both in Lower California), Brandegee; San Clemente and Santa Catalina islands, Mrs. Trask, nos. 10 and 20; Santa Catalina Island, Grant, no. 519; Witch Creek, 1893, Alderson; Valley Center, Jun., 1901, Sparkman; Ramona, Mar., 1906, Mrs. Brandegee; near Riverside, Geo. R. Hall; near San Bernardino, Parish, no. 4375; Playa del Rey, Hall, no. 3773; Pasadena, May 16, 1904, Grinnell; Mt. Wilson, at 1800 m. alt., Grinnell, no. 85e; Santa Monica Forestry Station, Barber, no. 69; Kaweah River, 30 kilometers east of Visalia, P. S. Woolsey; near Monterey, Heller, no. 6508 .

The following have very narrow and acuminate leaves 5 to 8 cm. long: Pasadena, Grant, no. 516; Arroyo Seco, Jul. 8, 1904, Grinnell; Santa Anita Cañon, Aug. 3, 1904, Grinnell.

Allied to G. leucocephalum Gray, from which it may be distinguished by its more branching habit and by the broad auriculate leaves. From $G$. decurrens and its variety it differs notably in the woody character of its stem and the more dense and persistent tomentum of the stem and of the lower surface of the leaves.

4. G. decurrens Californicum (DC.) Gray, Bot. Calif. i. 341 (1876). G. Californicum DC., Prodr. vi. 224 (1837). CaliFORNIA EverLasting.

Stems stout, 4 to $8 \mathrm{dm}$. high, from a biennial root, cymosely branched at summit, the branches bearing glomerules of large heads and forming a broad and somewhat flat-topped inflorescence: herbage soon becoming green and more or less glabrate, at maturity glandular and balsamic-scented: lower leaves oblong ( 6 to $12 \mathrm{~cm}$. long, 1 to $2 \mathrm{~cm}$. broad), diminishing in size upward and becoming lanceolate, all obviously decurrent: involucre 6 or $7 \mathrm{~mm}$. high, roundish, its bracts white or in age rusty-tinged.

San Bernardino, Parish, in a very robust broad-leaved form; near Redlands, Dr. R. J. Smith, no. 20 (similarly broad-leaved); Echo Mt., Pasadena, Santa Monica, Santa Catalina Island, and e]sewhere in Los Angeles Co.; thence northward. Common to- 
ward the coast in middle and northern California. G. bicolor has often been mistaken for this species in Southern California.

5. G. ramosissimum Nutt., Pl. Gamb. 172 (1848). PINK EvERLASTING.

Slender, 5 to $15 \mathrm{dm}$. high: stems usually several from the biennial root, terminating in a much branched oblong panicle which is often $3 \mathrm{dm}$. or more long: herbage glandular and very sweet-scented, soon becoming green through the shedding of the light tomentum, only the stem remaining more or less arachnoid: leaves linear or linear-lanceolate, seldom more than 5 or $6 \mathrm{~mm}$. broad, obviously decurrent: involucre narrowly ovate or turbinate, 4 to $6 \mathrm{~mm}$. high, reddish or pinkish, rarely white.

Wooded slopes from the south base of the San Antonio Mts. (Leslie Cañon, Chandler) and Los Angeles (Griffith Park, Braunton, no. 643, ete.) to the Sacramento. Not common in Southern California.

6. G. microcephalum Nutt., Trans. Am. Philos. Soc. ser. 2, vii. 404 (1841). Small-headed Everlasting.

Three to 6 or $9 \mathrm{dm}$. high: stems commonly several from the herbaceous perennial base, branching above into an elongated or sometimes broad loose panicle, which is usually less than $3 \mathrm{dm}$. (mostly 1 or $2 \mathrm{dm}$.) long: herbage clothed with a bright-white persistent woolly tomentum : leaves linear, or narrowly oblong, or spatulate, the larger ones 4 to $6 \mathrm{~cm}$. long and 3 to $12 \mathrm{~mm}$. broad, mostly short-decurrent: heads small, disposed in rather small glomerules or elusters at the ends of the branches of the panicle: involucre narrow, 5 or $6 \mathrm{~mm}$. high; bracts ovate or oblong and obtuse at apex, or the very innermost linear, bright white.

Lower California (San Vicente, Orcutt, no. 1239) to Shasta (Grant, no. 5075) and, ace. to Gray, to Oregon both along the coast (including Santa Rosa Island, etc.) and in the mountains to at least $1800 \mathrm{~m}$. alt. (Strawberry Valley, Bear Valley, etc.). The type specimens, which came from San Diego, are described by Nuttall as having heads conglomerate in a short spike about $5 \mathrm{~cm}$. long and white-silvery acute bracts.

7. G. Chilense Spreng., Syst. iii. 480 (1826). G. Sprengelii H. \& A., Bot. Beech. 150 (1833). Сотton-batting Plant. 
Plant 1.5 to $6 \mathrm{dm}$. high from an annual or biennial root, stems either several and erect from a decumbent base or single and wholly erect, terminating in a large close glomerule or branching above into a more or less open panicle (this less than $1.5 \mathrm{dm}$. long) the branches of which are terminated by close glomerules: leaves narrowly spatulate (the larger ones 3 to $6 \mathrm{~cm}$. long, 4 to 12 $\mathrm{mm}$. broad) or the uppermost ones linear or lanceolate, the shortdecurrent base rather broad and somewhat auricle-like: involucre roundish, 5 or $6 \mathrm{~mm}$. high and brođd, the bracts with a greenishyellow tinge.

Common on sandhills near the coast (San Diego, Santa Monica, ete.); plentiful in moist places toward the foothills (Witch Creek, San Bernardino, Pasadena, Ojai, ete.) ; less common in the Transition Zone of our mountains (San Jacinto Mts., at $1600 \mathrm{~m}$. alt.), and on the desert (Palm Springs, Calexico); north to Oregon, east to Texas and Mexico.

Var. confertifolium, Greene, Fl. Fr. 400 (1897). A stout and low form with linear leaves densely elothing the stem up to the mostly sessile dense cluster of heads.-Near Los Angeles, Braunton, nos. 237, 628; Mt. Pinos, Hall, no. 6591; and northward with the species.

G. Wrightil Gray has been reported from Ojai, Ventura Co., by Miss Eastwood, ${ }^{23}$ but I am unable to find specimens of this species from west of Arizona. It is related to G. microcephalum, but the spatulate or lanceolate leaves are not at all decurrent.

Anaphalis margaritacea (L.) B. \& H. has been reported from Santa Catalina Island by Mr. Brandegee, ${ }^{24}$ but his specimens eannot now be found. Since it is not otherwise known from south of the Sierra Nevadas of Kern Co., an error in the determination is suspected. This suspicion is strengthened by the fact that other botanists have distributed Gnaphalium bicolor from this island under the name of Anaphalis margaritacea, which may be distinguished from all species of Gnaphalium by the dioecious flowers.

23 Eryth. iv. 32 (1896).

24 Zoe i. 114 (1890). 


\section{Tribe 4. ambrosieaE. Ragweed Tribe.}

\section{IVA L.}

Ours coarse herbs and low shrubs with thickish alternate (or the lower opposite) leaves and small nodding heads of greenishwhite flowers. Receptacle with chaff-like linear or spatulate bracts. Marginal flowers of the head pistillate, 1 to 5 in number, their corollas tubular or none. Disk-flowers perfect, with 5-lobed funnelform corolla and undivided style. Anthers almost distinct. Achenes somewhat flattened, glabrous.

Involucral bracts united into a cup: stems herbaceous

1. I. axillaris. Involucral bracts distinct: stems suffrutescent

2. I. Hayesiana.

1. I. axillaris Pursh., Fl. 743 (1814). Poverty-weed.

Herbaceous perennial with creeping rootstocks, 1.5 to $5 \mathrm{dm}$. high: stems many, erect from a mostly decumbent or prostrate base: herbage pubescent or glabrous: leaves sessile, entire, narrowly obovate varying to lanceolate or linear, 1 to $3 \mathrm{~cm}$. long: heads solitary in all the upper axils, short-peduncled, surpassed by the leaves: bracts of the involucre united into a lobed or merely toothed cup $3.5 \mathrm{~mm}$. high.

In saline or alkaline soil from Southern California (coast of San Diego Co., Coahuilla Valley, Colton, Bear Valley, Cushenberry Springs, Antelope Valley, Ventura Co., Panamint Mts.) to British Columbia and Nebraska.

2. I. Hayesiana Gray, Proc. Am. Acad. xi. 78 (1876).

Stem suffrutescent, branched from the base, the ascending branches 6 to $9 \mathrm{dm}$. high: herbage strigose-puberulent or nearly glabrous : leaves spatulate-oblong or linear, narrowed to the base, obtuse, entire or rarely with one or two short teeth, 3 to $6 \mathrm{~cm}$. long, 6 to $12 \mathrm{~mm}$. wide, the upper ones lanceolate and slightly if at all surpassing the heads: involucral bracts about 5, distinct, roundish.

Brackish or alkaline soil of western San Diego Co. and southward: near Warner's Ranch, Oct. 4, 1858, Sutton Hays; Tia Juana Wash, Abrams, no. 3514; Elida, Lower California, Dr. Veitch; Socorro and Cañon de Gato, Lower California, Brandegee; Cedros Island, Anthony, no. 41. 


\section{OXYTENIA Nutt.}

Shrubby perennial with erect branches. Leaves alternate, 3 to 5-parted into filiform divisions, or the upper ones often sparse and entire. Involucral bracts about 5, somewhat coriaceous, their tips rigidly acuminate. Bracts of the receptacle slender, chaffy, with cuneate-dilated tips. Pistillate flowers about 5 , destitute of corolla; staminate flowers 10 to 20. Young achenes obovate, very villous with long soft hairs, terminated by a large areola. Pappus none or a mere vestige.

1. 0. acerosa Nutt., Pl. Gamb. 172 (1848).

Stems canescent, half-woody, 1 to $2 \mathrm{~m}$. high, sometimes leafless and rush-like, sometimes covered with leaves $1.5 \mathrm{dm}$. or less long: heads $4 \mathrm{~mm}$. high, numerous, in dense panicles.

Alkaline plains from eastern California and Arizona to Utah: southeastern Inyo Co., acc. to Coville. I have seen no specimens from this State. Flowers sometimes pleasingly fragrant with the odor of lilacs, ace. to Miss Eastwood.

\section{DICORIA T. \& G.}

Diffusely branched annuals of the Desert Area. Upper leaves alternate. Inflorescence loosely paniculate. Involucral bracts 6 or 7 , distinct; the 5 outer ones herbaceous; 1 or 2 of the inner ones much larger, scarious and subtending the fertile flowers, or these wanting in staminate heads. Receptacular bracts few, narrow. Pistillate flowers 1 or 2 , destitute of corolla; staminate flowers 6 to 12, their filaments almost free from the corolla and monadelphous up to the lightly connected anthers. Achenes surpassing the outer involucre, convex on the dorsal side, flat on the anterior face, conspicuously margined with a scarious pectinate border. Pappus of several small squamellae.

1. D. canescens T. \& G., Bot. Mex. Bound. 87, t. 30 (1859).

Plant 3 to $10 \mathrm{dm}$. high: herbage eanescent with a harsh spreading pubescence, or this somewhat appressed: leaf-blades 1.5 to $3 \mathrm{~cm}$. long, on evident petioles, ovate, obtuse, from sinuousdentate to laciniate, 3-nerved from the broad base; uppermost 
leaves minute and scattered: heads nodding in fruit: outer involucre $2 \mathrm{~mm}$. high.

In dry sandy soil, Lower Sonoran Zone: Whitewater, Colorado Desert, Parish, Schellenger (no. 50) ; Daggett, Mohave Desert, and Inyo Co., ace. to Coville; east to Arizona and southern Utah. Also as a waif at East Los Angeles, Davidson.

\section{HYMENOCLEA T. \& G.}

Diffusely branched xerophytic shrubs with glabrous or minutely canescent herbage. Leaves alternate, filiform, entire or the lower parted into filiform lobes. Heads numerous, small, staminate and pistillate either intermixed in the panicles or the latter in the lower axils. Involucre of staminate flowers saucer-shaped, commonly 4 to 6 -lobed. Pistillate flowers solitary; the involucre ovoid or fusiform, beaked at apex and winged with broad searious scales.

Scales of pistillate involucre spirally alternate, imbricated..... H. Salsola. Pistillate involucre winged only from the middle with a single whorl of seales. 2. H. monogyra.

1. H. Salsola T. \& G., Pl. Fendl. 79 (1849).

An erect bushy shrub, commonly $1 \mathrm{~m}$. high : leaves sparse, .5 to 3 (rarely 7 ) $\mathrm{cm}$. long: scales of the pistillate involucre spirally arranged from the base to near the middle, orbicular and often with a mucro, nearly $5 \mathrm{~mm}$. wide, the margins commonly erose.

Common in sandy washes and alkaline soil throughout the Lower Sonoran Zone in the Desert Area: Lower California, Palm Springs, Coyote Cañon, Mecea, Flowing Wells, Paloverde, Barstow, Antelope Valley, and Inyo Co. Also near Bakersfield, Kern Co., Apr. 9, 1893, and Cuyama, Santa Barbara Co., May 6, 1896, both by Miss Eastwood.

2. H. monogyra T. \& G., Pl. Fendl. 79 (1849).

Branches commonly less spreading and more leafy than in no. 1 : scales of the pistillate involucre 7 to 9 , in a single whorl around the middle, obovate with a minute mucro, only 1 or $2 \mathrm{~mm}$. wide, the margins erose.

In washes from Mission Valley, near San Diego, and Lower California east to Arizona and Texas, in the Lower Sonoran Zone. 


\section{AMBROSIA L. RAGWEED.}

Ours coarse perennial monoecious herbs with mainly alternate pinnatifid leaves and inconspicuous greenish flowers. Staminate heads nodding, in erect ament-like leafless racemes; involucral bracts united into a broadly turbinate cup; receptacle with slender bracts subtending at least the outer flowers; corollas funnelform, 5-lobed. Pistillate heads in the axils of the upper leaves at the base of the staminate racemes; involucre oblong or turbinate, closed, containing but a single flower; corolla none; pappus none; fruit an achene-like bur which is beaked or pointed and commonly armed near the top with a single row of prickles.

Herbage rough-pubescent: leaf-lobes lanceolate, acute....1. A. psilostachya. Herbage soft-pubescent: 1eaf-lobes crowded, short-oblong, obtuse.

2. A. pumila.

1. A. psilostachya DC., Prodr. v. 526 (1836). Western RAGWEED.

Stems simple, erect, commonly 5 to 10 (2 to 15 ) dm. high from slender running rootstocks: herbage scabrous or shorthirsute, somewhat strigose: leaves once or the lower twice pinnatifid, with acute lobes: fruit an obovoid turgid bur, about 3 $\mathrm{mm}$. long, mostly solitary in the axils, pubescent, rugose-reticulated, bearing 4 protuberances or sometimes unarmed.

A common weed along roadsides and in waste places throughout western North America.

2. A. pumila (Nutt.) Gray, Proc. Am. Acad. xvii. 217 (1882). Franseria pumila Nutt., Trans. Am. Philos. Soc. ser. 2, vii. 344 (1841).

Stems often branching, erect, $4.5 \mathrm{dm}$. or less high from slender running rootstocks : herbage canescent with a dense soft pubescence: leaves mainly alternate, long-petioled, crowded, as also are their numerous short-oblong or narrower obtuse lobes : fruit said to be $2 \mathrm{~mm}$. long, obovoid, muticous, the surface pubescent.

Known only from the vicinity of San Diego: Nuttall, Cleveland, etc., ace. to Gray; Purpus, Miss Rose Smith, Mrs. Brandegee. 


\section{FRANSERIA Cav.}

Herbs or shrubs with chiefly alternate leaves. Habit, flowers, and inflorescence as in Ambrosia. Pistillate heads 1 to 4-flowered; the involucre closed, 1 to 4-celled and 1 to 4-beaked or -pointed, armed with several rows of prickles, in fruit becoming a bur.

Stems herbaceous (leaves pinnatifid or pinnately parted except some in no. 4).

Fruiting involucre (bur) $3 \mathrm{~mm}$. or less long, its spines mostly uncinate 1. F. tenuifolia.

Fruiting involucre larger, its spines straight.

Staminate heads 2 to $4 \mathrm{~mm}$. broad: spines thin: inland species. 2. F. acanthicarpa.

Staminate heads 5 to $7 \mathrm{~mm}$. broad: spines thick: seashore species.

Leaves twice or thrice pinnatifid or pinnately parted.

3. F. bipinnatifida.

Leaves (at least the upper) merely serrate 4. F. Chamissonis.

Stems woody (leaves parted only in no. 5 and sometimes in no. 7 ).

Petioles present: leaves not spinosely dentate.

Leaves pinnately parted: bur with straight glabrous or minutely pubescent spines. 5. F. dumosa.

Leaves ovate, obtusely dentate or nearly entire: bur with uncinate spines woolly at base. 6. $F$. chenopodiifolia.

Leaves various: bur with straight spines villous to the tip.

7. F. eriocentra.

Petioles none: leaves spinosely dentate

8. F. ilicifolia.

1. F. tenuifolia Gray, Pl. Fendl. 80 (1849). Gaertneria temuifolia Kuntze, Rev. Gen. i. 339 (1891).

An erect herbaceous perennial, 3 to $15 \mathrm{dm}$. high: herbage variously pubescent or glabrate, but usually hispid: leaves pinnately parted or dissected into narrowly oblong or linear lobes and the primary rachis often with some interposed small lobes, the terminal lobe elongated: staminate racemes paniculately disposed: fruiting involucres glomerate below, minutely glandular, obovate with narrow base, about $2.5 \mathrm{~mm}$. long, usually 2 -flowered; spines stout, incurved and nearly always hooked, a cartilaginously bordered pit above each.

Common at Hollywood and Cahuenga Pass, near Los Angeles, 
acc. to Davidson and to Abrams; dry plains near San Bernardino, San Jacinto, and San Felipe, ace. to Parish; Colorado to Mexico.

2. F. acanthicarpa (Hook.) Coville, Contr. U. S. Nat. Herb. iv. 129 (1893). Ambrosia acanthicarpa Hook., Fl., Bor. Am. i. 309 (1834). Franseria Hookeriana Nutt., Proc. Am. Philos. Soc. ser. 2, vii. 345 (1841). Gaertneria acanthicarpa Britton, Mem. Torr. Club v. 332 (1894).

Diffusely spreading or sometimes rather strict, 3 to $6 \mathrm{dm}$. or more high, from an annual (or more enduring?) root: herbage scabrous or short-hirsute and somewhat canescent: leaves on long petioles, broadly ovate in outline, once or twice pinnatifid into short rounded often toothed lobes: staminate racemes solitary or in small panicles, the heads nodding on short slender peduncles: fruiting involucres in the axils below, either solitary or 2 or 3 together, 1-flowered, glabrous; spines flat, thin, lanceolate-subulate, with straight or slightly eurved but not uncinate tips.

Common on sandy plains and in stubble from Southern California (Valley Center, Van Deventer Flat, San Bernardino, Los Angeles, Mohave Desert, Ft. Yuma, etc.) to Washington and Colorado.

3. F. bipinnatifida Nutt., Trans. Am. Philos. Soc. ser. 2, vii. 344 (1841). F. Chamissonis bipinnatisecta Less., Linnaea vi. 507 (1831). Gaertneria bipinnatifida Kuntze, 1. c.

Stems procumbent, 6 to $10 \mathrm{dm}$. long, from an herbaceous perennial root, somewhat hirsute: leaves 3 to $10 \mathrm{~cm}$. long, twice or thrice pinnately parted into oblong lobes, canescent or almost silky : staminate heads in dense terminal spikes or racemes: fruiting involucre ovate-fusiform, armed with thick somewhat flattened spines, some of which are curved at the tip, but not at all hooked.

Common in sandy places along the beach from San Martin Island (off the coast of Lower California), San Diego, and Santa Catalina Island to British Columbia.

Probably only a form of $F$. Chamissonis, since the two commonly occur together, and intermediate leaf-forms are plentiful at least on the San Francisco Peninsula.

4. F. Chamissonis Less., Linnaea vi. 507 (1831). Gaertneria Chamissonis Kuntze, l. c. 
Habit, pubescence, etc. of $G$. bipinnatifida but the leaves narrowly ovate or obovate with cuneate base and merely serrate, or the lower laciniate or incised or even pinnately parted into oblong divisions which are again lobed; bur thicker, sparsely hirsute, the spines broader and channeled.

San Miguel Island, Sept., 1886, Greene; San Clemente Island, Mrs. Trask (leaves only); seaboard of middle California to Washington.

F. Camphorata Greene, Bull. Calif. Acad. i. 192 (1885), of Lower California, may reach our southern border. It is much like $F$. bipinnatifida but the burs are globose, with short stout spine-tipped tuberculations which are not at all flattened : herbage resinous and with the odor of camphor.

5. F. dumosa Gray, Frem. 2nd. Rept. 316 (1845). Gaertneria dumosa Kuntze, 1. c. SAND-BUR.

A low spreading shrub, seldom over $5 \mathrm{dm}$. high, with rigid and brittle branches: herbage whitened with a fine close pubescence: leaves small (commonly 1 or $2 \mathrm{~cm}$., rarely $4 \mathrm{~cm}$. long), pinnately parted into few short very obtuse lobes: fertile involucre mostly 2-flowered, glabrous or pubescent, globular, its spines tapering from a broad flat base to a straight acerose tip.

Abundant on the Colorado and Mohave deserts; east to Utah and south into Mexico; a characteristic species of the Larrea belt of the Lower Sonoran Zone.

6. F. chenopodiifolia Benth., Bot. Sulph. 26 (1844).

Plant low, much branched, the stems woody only at base: herbage pubescent with a very close and soft tomentum, the upper surface of the leaves glabrate: leaves round-ovate, obtuse, the base varying from almost truncate to cuneate, sinuate-crenate to obtusely dentate, 1.5 to $3 \mathrm{~cm}$. long, on margined petioles 1 or 2 $\mathrm{cm}$. long: fertile involucre globular, 2 or 3-flowered, arachnoid between the spines, these lanceolate-subulate and hooked at the tip.

Tia Juana, San Diego Co., Apr., 1902, Grant, no. 1637 ; Apr., 1903, Hall, no. 3974; May 14, 1903, Abrams, no. 3476 : Lower California, Orcutt, Greene, Palmer, Brandegee, Barkelew, Purpus. Apparently a Lower Sonoran species. 
7. F. eriocentra Gray, Proc. Am. Acad. vii. 355 (1868). Gaertneria eriocentra Kuntze, l.c.

Shrubby, 3 to $9 \mathrm{dm}$. high, with numerous rigid branches: herbage canescent with a minute tomentum, the leaves soon glabrate and green above: leaves cuneate-oblong to lanceolate, from sinuately few-toothed or -lobed to sparingly and irregularly sinuate-pinnatifid, nearly sessile by an attenuate base, 1.5 to 2.5 $\mathrm{cm}$. long: pistillate involucre 1-flowered, equalled by its single subulate beak and clothed with whitish wool which is almost as long as the straight rigid subulate spines.

Providence Mts., Mohave Desert, Cooper (ace. to Gray), Brandegee; Arizona, Palmer, no. 611, also Apr., 1886, Miss Shattuck, and Jun., 1884, Lemmon; Nevada, Jones, no. 5065.

8. F. ilicifolia Gray, Proc. Am. Acad. xi. 77 (1876). Gaertneria ilicifolia Kuntze, l. c.

Shrubby, the branches hirsute or hispid, leafy to the summit: leaves rigidly coriaceous, scabrous, oblong or ovate, sessile by a clasping auriculate base, 2.5 to $5 \mathrm{~cm}$. long, coarsely dentate with spinose teeth and tipped with a rigid spine: fertile involucre ovoid, glandular-pubescent, $12 \mathrm{~mm}$. broad including the very numerous slender uncinate prickles.

Signal Mt.; Colorado Desert, Imperial Co., Mar. 30, 1901. Brandegee; same station, Abrams, no. 3184; Cajon de Santa Maria, Lower California, May 14, 1889, Brandegee.

F. AMbrosioides Cav., a shrubby species of Arizona and Mexico, is to be looked for along our southeastern borders. Leaves oblong-lanceolate, dentate or serrate, 5 to $10 \mathrm{~cm}$. long : bur nearly $12 \mathrm{~mm}$. long, with slender uncinate-tipped prickles $4 \mathrm{~mm}$. long.

\section{XANTHIUM L.}

Coarse annual weeds with widely branching and very stout stems. Leaves alternate, toothed or lobed, petioled. Heads unisexual, the flowers greenish. Staminate heads subglobose, in a terminal cluster; involucre of several distinct narrow bracts in 1 or 2 series; receptacle eylindrical; flowers many, separated by the bracts of the receptacle; corolla tubular. Pistillate heads 
axillary, below the staminate; involucre closed, forming in fruit an ovoid or oblong indurated bur covered with hooked prickles, 1 or 2-beaked, 2-celled, each cell containing 1 flower; corolla none; pappus none; style 2-cleft, its branches exserted through the beaks.

Leaves deltoid-ovate, their axils not spiny 1. X. Canadense. Leaves lanceolate, their axils bearing 3 -divided spines. 2. X. spinosum.

1. X. Canadense Mill., Gard. Dict. ed. 8, no. 2 (1768). COCKLEBUR.

About $6 \mathrm{dm}$. high: herbage scabrous : leaves deltoid-ovate or somewhat cordate, irregularly serrate or incised, often distinctly 3-lobed, green on both sides, 6 to $12 \mathrm{~cm}$. long, on petioles nearly as long: bur 2 to $2.5 \mathrm{~cm}$. long, 1 to $1.5 \mathrm{~cm}$. thick, pubescent or glandular between and on the lower part of the crowded prickles and bearing at apex a pair of strong beaks hooked or incurved at tip.

A common weed along ditches and in waste places. Introduced from eastern North America. Ace. to Hoffmann, ${ }^{25} X$. Canadense is not specifically distinct from $X$. orientale $\mathrm{L}$.

2. X. spinosum L., Sp. Pl. 987 (1753). Spiny Clotbur.

Stem puberulent, much branched: leaves lanceolate or ovatelanceolate, acute or acuminate, 2 or 3-lobed or -cut, or the upper entire, narrowed at base into a short petiole, green above, whitepubescent beneath, 5 to $10 \mathrm{~cm}$. long: by the sides of the leaves are borne yellowish 3-pronged spines 2 or $3 \mathrm{~cm}$. long: corolla pubescent with short rusty hairs: bur narrowly oblong, about $12 \mathrm{~mm}$. long, sparsely beset with weak hooked prickles; beaks inconspicuous, only one of them spine-like.

An occasional weed in waste ground; increasing rather rapidly and far too common in some places. Probably a native of South America (ace. to Ascherson), but reaching us by way of Europe.

25 Hoffmann, in Engler \& Prantl, Natürl. Pflanzenf. iv. abt. 5, 223 (1890). 


\section{Tribe 5. HeliantheaE. Sunflower Tribe.}

\section{BEBBIA Greene.}

Half-shrubby strongly scented xerophytes with green and nearly leafless intricately branched stems. Heads long-pedunculate or two or three together terminating the branches, discoid. Bracts of the involucre in about 3 rows, obscurely striate. Bracts of the receptacle scarious, lanceolate, concave and partially enfolding the achenes. Flowers homogamous, yellow. Achenes linear or turbinate, densely pubescent with long appressed hairs. Pappus of about 15 plumose bristles, longer than the achene.

1. B. juncea (Benth.) Greene, Bull. Calif. Acad. i. 180 (1885). Carphephorus junceus Benth., Bot. Sulph. 21 (1844).

Plant 5 to $10 \mathrm{dm}$. high, the woody portion with a smooth gray bark which becomes fibrous: herbage perfectly smooth in the typical form: leaves opposite below, alternate above, very remote or almost none, linear (rarely oblong), sometimes with a few short lobes: involuere 4 to $8 \mathrm{~mm}$. high; outer bracts from oblong and obtuse to lanceolate and acute; inner bracts lanceolate, acute, brown or reddish in color.

Western San Bernardino Co. to Lower California, in the Lower Sonoran Zone: Cedros, Natividad, and Magdalena islands, off the coast of Lower California, and on the adjacent mainland, various collectors; cañon of the Santa Ana River, Orange Co., Hall, no. 6729; Point of Rocks, near Riverside, Hall, no. 3803 (peduncles minutely seabrous); Rubidoux Mt., Riverside, $S$. Grout (peduncles smooth); City Creek wash, near Highlands, San Bernardino Co., Abrams, no. 2803.

Var. aspera Greene, l. c. B. aspera A. Nelson, Bot. Gaz. xxxvii. 273 (1904). Herbage scabrous with upturned white hairs, or these deciduous from the stems leaving only the pustule-like base.-Near Foster, San Diego Co., Mrs. Brandegee; San Jacinto River at west base of San Jacinto Mt., Hall, no. 2674 (westernmost station for the variety, leaves and stems very rough); common in sandy and stony places on the Colorado Desert, less common on the Mohave Desert and in eastern Inyo Co., east to Nevada and Arizona. 


\section{GALINSOGA R. \& P.}

Annual herbs with opposite leaves and inconspicuous solitary or cymose heads. Involucre nearly hemispheric, of few ovate thin and striate nearly equal bracts in two series and often some additional outer and much smaller ones. Ray-flowers 4 or 5, fertile, with 2 or 3-lobed white ligules, these often very small. Receptacle conical. Pappus of several broad paleae with fimbriate or almost plumose margins, or wanting in the ray-flowers.

1. G. parviflora Cav., Ie. iii. 41, t. 281 (1794).

Plant 2 to $6 \mathrm{dm}$. high, with slender ascending branches, leafy almost throughout: herbage more or less pubescent: leaves thin, ovate to lanceolate, acute, entire or serrate, 2 to $6 \mathrm{~cm}$. long beyond the petiole: heads long-pedunculate, barely $4 \mathrm{~mm}$. high: rays scarcely exserted: achenes black, turbinate, 4 or 5-angled: diskpappus of 8 to 16 broad paleae nearly as long as the achene.

Adventive in waste places at Los Angeles (near University Station, and at Vernon) where its appearance was first made in 1902, when it was collected by Greata, Braunton, Grant, and others. Native of Mexico and South America.

\section{BALSAMORHIZA Hook. BALSAM Root.}

Low perennials with thick roots crowned by a tuft of radical leaves and several naked or few-leaved stems bearing one or several heads of yellow flowers. Bracts of the broad involucre either nearly equal or the outer ones foliaceous. Ray-flowers pistillate and with conspicuous ligules. Achenes destitute of pappus, those of the disk 4-sided.

1. B. deltoidea Nutt., Trans. Am. Philos. Soc. ser. 2, vii. 351 (1841). B. glabrescens Benth., Pl. Hartweg. 317 (1849).

Herbage green and more or less scabrous throughout or somewhat tomentose below and on the involucres: seapes 2 to 4 or 7 $\mathrm{dm}$. high: petiole of radical leaves stout, 1 or $2 \mathrm{dm}$. long; blade ovate or lanceolate, cordate at base, 1 to $2 \mathrm{dm}$. long, 8 to $15 \mathrm{~cm}$. broad, the entire or serrate margins sinuate: cauline leaves few and small, lanceolate with narrowed base: outer bracts of the involucre commonly foliaceous, obtuse or acute, 1.5 to $4 \mathrm{~cm}$. long; 
inner bracts lanceolate, acute, 1 to $1.5 \mathrm{~cm}$. long: rays 1.5 to $3 \mathrm{~cm}$. long, 3 -toothed at apex or entire.

Principally in the Upper Sonoran Zone: Mono Creek, Santa Barbara Co., Hall, no. 7797; near Manzana, Antelope Valley, Los Angeles Co., Davy; summit of Tejon Pass, Los Angeles Co.; Tehachapi Valley, Kern Co.; north to British Columbia.

It has been suggested ${ }^{26}$ that the California plants commonly referred to this species should be separated from the "true" $B$. deltoidea of Oregon and Washington as a distinet geographical variety or species, because of their seabrous leaves and smooth or merely hirsute involucres. These variations, however, are not strictly geographic, some specimens from Southern California (Davy, no. 2185 , etc.) now at hand exhibiting tomentose involucres and scarcely scabrous leaves while some Oregon specimens (Cusick, no. 1679) have scabrous involueres and foliage; and perhaps this latter form is typical $B$. deltoidea, which Nuttall described as "wholly green."

\section{WYETHIA Nutt.}

Perennial herbs with very stout roots crowned by a short caudex which bears a tuft of ample mostly entire leaves. Involucre hemispheric or campanulate, its bracts in 2 or 3 series, the outermost often foliaceous and much enlarged, the innermost small and bract-like. Receptacle flat or nearly so ; its bracts rigid, linear or lanceolate, either flattish or partially folded around the achenes. Flowers yellow (varying to white in one species), fertile in both ray and disk, the latter perfect. Branches of the style in perfect flowers produced into subulate-filiform hispid appendages. Achenes prismatic-quadrangular or in the ray triangular. Pappus firm and persistent, consisting of a crown of unequal scales, or with rigid awns at the angles.

1. W. ovata T. \& G., Emory's Rept. 143 (1848); Abrams, Bull. Torr. Club xxxii. 541 (1905). Not W. ovata Gray, Proc. Am. Acad. vii. 357 (1867), Syn. Fl. i. pt. 2, 268 (1884), ete. W. coriacea Gray, Proc. Am. Acad. xi. 77 (1876); Hall, Univ. Calif. Pub. Botany, i. 131 (1902).

26 Coville, Contr. U. S. Nat. Herb. iv. 130 (1893). 
Herbage densely tomentose, the leaves somewhat glabrate: stems leafy, $1 \mathrm{~m}$. or less high, sometimes very short or almost none: leaves firm-coriaceous, entire, broadly ovate or oval, from 1 to nearly $2 \mathrm{dm}$. long, on petioles of various lengths: heads short-penducled or subsessile, nearly hidden by the leaves: outer bracts of the involucre oblong-lanceolate, foliaceous, usually exceeding the rays; inner bracts 1.5 to $2 \mathrm{~cm}$. long: rays 5 to 9 , barely $1.5 \mathrm{~cm}$. long: pappus forming a crown about the summit of the achene, variously cleft, the lobes sometimes awn-like, sometimes broad and entire or fimbriate.

In dry clayey soils at altitudes of 750 to $1400 \mathrm{~m}$., in northern Lower California (Jul. 7, 1885, Orcutt), San Diego Co. (Laguna, Julian, Mesa Grande), and Riverside Co. (Palomar and San Jacinto Mts.). May-Jul.

\section{VIGUIERA HBK.}

Ours shrubby plants with slender brittle stems and hispidulous-scabrous petioled leaves, at least the lower of which are opposite. Heads medium-sized, conspicuously pedunculate near the ends of the branches, the peduncles not thickened at summit. Bracts of the involucre herbaceous, imbricated. Bracts of the receptacle persistent and embracing the lightly compressed or 4-angled disk-achenes. Ray-flowers yellow, neutral. Pappus of two awns or acute paleae, one to each principal angle of the achene, and two or more intervening short erose paleae on each side.

Leaves lanceolate: involucre green: achenes sparsely pubescent.

..1. V. laciniata.

Leaves ovate: involucre cinereous: achenes densely villous: var. Parishii of 2. $V$. deltoidea.

1. V. laciniata Gray, Bot. Mex. Bound. 89 (1859).

Stems leafy to summit, branching to form a round-topped bush 6 to $12 \mathrm{dm}$. high: herbage scabrous-pubescent, resinous : leaves from pinnatifid to nearly entire, lanceolate from a broad often hastate base, acute, 2 to $5 \mathrm{~cm}$. long including the short petiole, the veins very prominent on the under side: involucre about $8 \mathrm{~mm}$. high; outer bracts ovate with abruptly acuminate spreading tips; inner bracts narrow, erect : rays 1 to $1.5 \mathrm{~cm}$. long : 
achenes sparingly pilose, glabrate: principal pappus-paleae, tapering into a slender awn shorter than the achene, obscurely denticulate throughout, deciduous, the intermediate scales erose or laciniate.

Southwestern San Diego Co. and Lower California; common back of San Diego.

2. V. deltoidea Parishii (Greene) Rose, Contr. U. S. Nat. Herb. i. 72 (1890). V. Parishii Greene, Bull. Torr. Club ix. 15 (1882).

A compact twiggy shrub 3 to $5 \mathrm{dm}$. high: leaves ovate, acute, short-petioled from the broad or truncate base, 1 to 3 (rarely 4 ) $\mathrm{cm}$. long including petiole, coarsely serrate or nearly entire: heads on conspicuous nearly naked peduncles: involucre about $8 \mathrm{~mm}$. high; outer bracts cinereous with a close pubescence, linearlanceolate, loose; inner bracts linear, erect: rays 1 to $1.5 \mathrm{~cm}$. long: achenes villous: awns of the pappus very slender, as long as the achene, obscurely chaffy at base, the intermediate scales erose or laciniate.

San Luis Rey Mission, western .San Diego Co., Apr., 1881, Parish, no. 963 (type); Vallecito, western San Diego Co., Parish, no. 963 B; Mountain Spr. Grade, San Diego Co., Cleveland, no. 366 ; occasional on benches and in cañons across the Colorado Desert, various collectors; Providence Mts., Mohave Desert, Brandegee; Lower California, Orcutt, Palmer, no. 250.

V. Reticulata Wats. has been collected only in Inyo Co. Somewhat like $V$. deltoidea Parishii but leaves "entire, canescent with soft appressed hairs above, prominently reticulated, and loosely tomentose beneath, not scabrous in any part. ${ }^{,}{ }_{27}$

\section{HELIANTHUS L. SUNFLOWER.}

Stout coarse herbs with rough leaves, yellow mostly entire rays, and brownish purplish or yellow disk. Leaves mostly alternate but the lower or lowest commonly opposite. Heads middlesized or large, hemispheric, solitary on the ends of the branches or in terminal cymes. Bracts of the involucre imbricated. Receptacle flat or convex, its bracts persistent and embracing the

27 Coville, Contr. U. S. Nat. Herb. iv. 130 (1893). 
achenes. Ray-flowers neutral. Achenes thick, slightly compressed, 4-sided or elliptic in cross-section. Pappus of pointed paleae borne at the angles of the achene, often with very small intervening scales, all caducous.

Annuals: receptacle flat or nearly so.

Involucral bracts ovate, abruptly attenuate. 1. H. annuus.

Involucral bracts lanceolate, gradually attenuate.

Foliage green: mountain species.

2. H. petiolaris.

Foliage white with a strigose pubescence: desert species.

3. H. tephrodes.

Perennials: receptacle convex to low-conical.

Outer bracts exceeding the disk, lanceolate or linear-subulate.

Pappus-paleae slender-subulate 4. H. Parishii.

Pappus-paleae broadly lanceolate. 5. H. Californicus.

Outer bracts not exceeding disk, ovate, acute 6. H. gracilentus.

1. H. annuus L., Sp. Pl. 904 (1753). (Сомmon Sunflower. Erect and simple or more or less branching, 5 to $30 \mathrm{dm}$. high : herbage rough-hispid: leaves petiolate, deltoid-ovate, serrate, the uppermost narrow and often entire: bracts of the involucre ovate, slenderly acuminate, ciliate: bracts of the receptacle 3-cleft at apex, the middle lobe lanceolate and longer than the others: rays about 2 or $3 \mathrm{~cm}$. long.

Common along roadsides and in waste places throughout western North America.

2. H. petiolaris Nutt., Journ. Phila. Acad. ii. 115 (1821).

Slender plant with simple or branched stems, 3 to $9 \mathrm{dm}$. high: herbage scabrous to sparsely strigose-pubescent: leaves lanceolate, acute, entire or nearly so, the blades about $5 \mathrm{~cm}$. long, narrowed to the petiole or the lower with broad base: involucre 1 to $1.5 \mathrm{~cm}$. high; its bracts lanceolate-acuminate, merely scabrous or obscurely ciliate, sometimes canescent at base but not villous: bracts of the receptacle 3-cleft at apex; middle lobe lanceolate, much longer than the others, somewhat hispid: rays about $2 \mathrm{~cm}$. long.

Fredalba Park, in the Transition Zone of the San Bernardino Mts., Miss Nora Pettibone, ace. to Parish; generally distributed in western North America. 
3. H. tephrodes Gray, Bot. Mex. Bound. 90 (1859) and Syn. Fl. i. pt. 2, 450 (1886) (where complete synonymy).

Slender, erect, the commonly simple stem 3 to $6 \mathrm{dm}$. high : herbage whitened with a dense hispidulous or strigose pubescence: blade of the main cauline leaves ovate-lanceolate, entire, 2.5 to $4 \mathrm{~cm}$. long, tapering to the petiole; uppermost leaves oblong to linear: heads short-peduncled in terminal clusters and solitary in axils of upper leaves : involucral bracts oblong-lanceolate, acute: rays large for the size of the head ( 2 or $3 \mathrm{~cm}$. long) : disk-achenes silky-pubescent (at least above), the long hairs nearly equalling the slender caducous paleae of the pappus.

Lower Sonoran Zone of the Colorado Desert, south into Sonora; rare: "Mirasol de Monte, in the Californian desert of the Colorado, in sandy places by the road-side; October, 1855, Schott," acc. to Gray; in sand at Palm Springs, Colorado Desert, 1882, Parish, no. 1212 (duplicate type of Gymnolomia encelioides Gray); Colorado Desert, 1889, Wright, no. 1750.

4. H. Parishii Gray, Proc. Am. Acad. xix. 7 (1883); Davidson, Bull. So. Calif. Acad. ii. 30 (1903). H. Oliveri Gray, Proc. Am. Acad. xx. 299 (1885).

Tall and stout, 2.5 to $5 \mathrm{~m}$. high, with thick tuber-like roots: pubescence extremely variable; the stems glabrous to short-hispid, sometimes tomentose near the heads; the leaves strigose or seabrous on the upper surface, strigose to densely white-tomentose beneath; the involucre more or less canescent: leaves lanceolate, acuminate, tapering to a short petiole, entire or nearly so, the margins inclined to be revolute, 10 to $25 \mathrm{~cm}$. (or more?) long, 1 to 2 or $3 \mathrm{~cm}$. wide: heads short-peduncled, the peduncles commonly exceeded by the upper leaf-like bracts : involucre 10 to 18 $\mathrm{mm}$. high, its bracts linear-subulate: chaff of the receptacle with abrupt densely ciliate tips : rays 2 to $3.5 \mathrm{~cm}$ : long: disk-corollas with a villous ring above the short proper tube, or this wanting in flowers from the same head: achenes glabrous: pappus-paleae linear-subulate, $4 \mathrm{~mm}$. or less long.

In wet places: near San Bernardino; low ground near Los Angeles; Cienaga, near Santa Monica; probably also along Spring Brook, near Riverside. The excellent specimens recently 
collected by Parish, Greata, Braunton, etc., as well as the cultural experiments carried on by Dr. Davidson (l. c.) furnish conclusive evidence that $H$. Parishii and $H$. Oliveri are in no way distinct. My own no. 2612 from Strawberry Valley, San Jacinto Mt., may belong here, or may be a form of $H$. Californicus, but is much too immature to be positively determined.

5. H. Californicus DC., Prodr. v. 589 (1836).

Erect, 1 to $3 \mathrm{~m}$. or more high, with somewhat tuber-like roots, the stems scabrous only toward the inflorescence: leaves scabrous on both sides, lanceolate or linear-lanceolate, some of the lower ones ovate, usually entire, 1 to $2 \mathrm{dm}$. long including the petiole: heads in a terminal cymose panicle, the peduncles leafy-bracteate: proper involucre 10 or $12 \mathrm{~mm}$. high; bracts imbricated, lanceolate, the outer ones tapering into spreading tail-like tips and sometimes 1.5 or $2 \mathrm{~cm}$. long, all scabrous : receptacular bracts obtuse: rays about 15 to $20,2 \mathrm{~cm}$. or more long: achenes glabrous : pappus of 2 or 3 lanceolate paleae.

National Ranch, San Diego, Jul., 1899, and Tehachapi, Mrs. Brandegee; along streams to middle California.

6. H. gracilentus Gray, Proc. Am. Acad. xi. 77 (1876).

Rather strict, erect, 6 to $12 \mathrm{dm}$. high, the stems rough-hispidulous or becoming smooth above: leaves short-hispid on both sides, entire or obscurely denticulate; the lower cauline ovatelanceolate, contracted to a short margined petiole, $15 \mathrm{~cm}$. or less long; the upper ones narrowly lanceolate or linear, entire: heads terminal on the elongated branches of the inflorescence; the peduncles much exceeding the upper leaves: involucre 7 to 10 $\mathrm{mm}$. high, shorter than the disk; the bracts imbricated, ovate, either abruptly or gradually contracted to the acute apex, all puberulent and the outer commonly ciliolate: receptacular bracts with pubescent obuse or acute tips : rays 12 to 16,2 to $2.5 \mathrm{~cm}$. long.

In dry gravelly or rocky soil on hillsides and in cañon bottoms of the Upper Sonoran Zone west of the mountains, from Mt. Gleason and Newhall, Los Angeles Co., to Ramona, San Diego Co.; near Claremont, Baker, nos. 3692, 4719; ete. 


\section{ENCELIA Adans.}

Herbs and low shrubs confined to the western part of North and South America. Leaves 3-nerved from the base, entire or remotely toothed. Heads on nearly naked peduncles, ours with showy yellow rays and yellow or purple disk. Ray-flowers neutral. Disk-achenes flat, in our species obovate or cuneate and with conspicuously ciliate margins, the sides either smooth or pubescent in the same species. Pappus none, or of 1 or 2 slender awns in some species.

Synopsis of THE SPECIES.

Perennials, the stems woody at least below.

Peduncles pubescent: heads solitary, terminating elongated simple branchlets which are leafy or bracteate below.

Involucre densely white-villous, 10 to $15 \mathrm{~mm}$. high: rays 1.5 to 3 cm. long: disk purple, the corolla-lobes either pubescent or glabrous: leaves green.

1. E. Californica.

Involucre canescent, 5 to $10 \mathrm{~mm}$. high: rays 1 to $1.5 \mathrm{~cm}$. long or none: disk yellow, the corolla-lobes pubescent: leaves green to white-tomentose 2. E. frutescens.

Peduncles smooth, glabrous: heads in cymes, the ultimate branches (peduncles) of which are relatively short and naked: involuere sparsely pubescent, 5 to $8 \mathrm{~mm}$. high: rays 1 to $1.5 \mathrm{~cm}$. long: disk yellow, the corolla-lobes glabrous: leaves white-tomentose.

3. E. farinosa.

Annual or biennial herbs (root of no. 5 unknown).

Heads radiate: involucral bracts acuminate, white-setose.

4. E. eriocephala.

Heads discoid: involucral bracts obtuse or merely acute, viseid.

.5. E. viscida.

1. E. Californica Nutt., Trans. Am. Philos. Soc. ser. 2, vii. 357 (1841).

Slender spreading stems 6 to $10 \mathrm{dm}$. high, shrubby only below, usually growing in clumps of considerable size: leaves ovate to lanceolate, acute, 2 to $6 \mathrm{~cm}$. long, narrowed to the petiole, green, minutely scabrous or glabrate: heads solitary, terminating elongated nearly naked pubescent peduncles: involucre densely whitevillous, 10 to $15 \mathrm{~mm}$. high: rays 16 to $30,1.5$ to $3 \mathrm{~cm}$. long: disk purple, 1.5 to $2.5 \mathrm{~cm}$. broad: corolla-lobes either smooth or pubescent. 
Common on dry hillsides of the Upper Sonoran Zone throughout Southern California, except on the desert; much resembling Helianthus gracilentus in external characters.

This species connects with $E$. frutescens through forms from Lower California in which the leaves, heads, and rays are all much reduced in size, Specimens of these southern forms have been repeatedly distributed as $E$. frutescens but their long-villous involucres and purple disk-flowers are exactly those of $E$. Californica. A teratological form occurs at San Diego, first noticed by Mrs. Brandegee, in which the ligules of the ray-flowers are often deeply cleft. Both normal and abnormal flowers are commonly found in the same head.

2. E. frutescens Gray, Proc. Am. Acad. viii. 657 (1873). Simsia frutescens Gray, Bot. Mex. Bound. 89 (1859).

A round-topped bushy shrub 6 to $12 \mathrm{dm}$. high, the stems commonly whitened by a rough cinereous pubescence: leaves 1 to 2.5 em. long, ovate to cblong or elliptic, narrowed to a short petiole, hispidulous-scabrous on both sides, or even cinereous-pubescent: peduncles rather long, terminating leafy branchlets, scabrous: involucre white-hispid, 5 to $10 \mathrm{~mm}$. high: rays few in number and $1.5 \mathrm{~cm}$. or less long or lacking: disk-flowers yellow, with pubescent teeth: pappus of 2 delicate long-villous awns or wanting.

Chiefly of the Desert Area, but extending from San Jacinto, Riverside Co., and the Greenhorn Mts., Kern Co., to Arizona and Utah.

As here characterized, this species includes a number of very perplexing forms. Certain of these have been recognized as distinct species, but the transitions between them are so gradual that a specific segregation seems inadvisable at present. It is possible, moreover, that some of these forms are of hybrid origin, since certain of them exhibit characters of E. Californica, others of $E$. farinosa. E. frutescens is best distinguished from the former by the shorter and canescent (never villous) hairs of the involucre and by the yellow disk; from the latter by its inflorescence and by the scabrous peduncles. The pappus is characteristic when present. The typical form, as first described by Gray, has scabrous and green leaves which are oblong or narrower, and 
discoid heads. It is represented by such collections as: SheepHole Mts., Mohave Desert, Hall, no. 6055; Bagdad, Mohave Desert, Brandegee; Cañon Springs and McCoy Wash, Colorado Desert, Hall, nos. 5859, 5939; Cariso Creek, Colorado Desert, Brandegee; Foothills Station, California, Lemmon, no. 51; Ord Mts., Mohave Desert, Hall \& Chandler, no. 6825; Panamint Valley, Inyo Co., Hall \& Chandler, no. 6906; California State Survey (locality not given); Peach Springs, Arizona, Jul., 1889, Greene (leaves ovate-oblong). The remaining material of $E$. frutescens now at hand may be segregated into the following forms:

f. radiata Hall, form. nov. Leaves ovate, rather large, scabrous and green: heads radiate.--Northern Arizona, Apr., 1893, Wilson; Grand Cañon, Arizona, Grant, no. 396; S.E. Utah, May, 1892, Miss Eastwood.

f. ovata Hall, form. nov. Leaves ovate, rather large, scabrous and green: heads discoid.-Signal Mt., Colorado Desert, Abrams, no. 3156; near Tueson, Arizona, May 8, 1884, Pringle; "Palmetto Springs," Stephens, no. 53.

f. Virginensis (A. Nelson) Hall, comb. nov. E. Virginensis A. Nelson, Bot. Gaz. xxxvii. 272 (1904). Leaves ovate, rather large, cinereous with a rough pubescence: heads radiate: outer involucral bracts linear-lanceolate.--Southern Nevada, Goodding, no. 666 (type number of $E$. Virgenensis) ; near St. George, Utah, Parry, no. 142; Inyo Co., Hall \& Chandler, no. 6903 (approaching $\mathrm{f}$. Actoni in pubescence).

f. Actoni (Elmer) Hall, comb. nov. E. Actoni Elmer, Bot. Gaz. xxxix. 47 (1905). Leaves ovate, large, whitened by a soft pubescence: heads large, radiate: outer involucral bracts ovateacuminate.-Acton, Los Angeles Co., Elmer, no. 3724; Greenhorn Range, Kern Co., Hall \& Babcock, no. 5091; Antelope Valley, Davy, no. 2643; Cabazon, Riverside Co., Dr. R. J. Smith, no. 302; Inyo Co., May, 1892, Brandegee (peduncles soft-pubescent); Walker Pass, Coville \& Funston, no. 1020; Olancha, Purpus, no. 1976 ; Inyo Co., Rixford, also Austin, no. 30; Providence Mts. May 30, 1902, Brandegee; Inyo Co., Purpus, no. 5383, also Hall \&. Chandler, nos. 7062, 7217, 7308; Ord Mts., Hall \& Chandler, no. 6812; San Jacinto, Hall, no. 2007; Utah, Jones, no. 5195; Nevada, Shockley, no. 540.-This form approaches $E$. farinosa 
in foliage and pubescence but has an entirely different inflorescence, the simple scabrous peduncles terminating leafy branchlets.

3. E. farinosa Gray, Emory Rept. 143 (1848). Incienso.

Plant 3 to $5 \mathrm{dm}$. high, commonly with a distinct trunk-like stem, the numerous short branches forming a round-topped leafy bush from the summit of which arise the long-stemmed cymes: leaves broadly ovate, acute or obtuse, 2 to 5 or $10 \mathrm{~cm}$. long, narrowed to the petiole, whitened by the dense silvery tomentum: heads cymose, the branches of the cyme perfectly smooth and naked except for a few minute bracts : involucre rather sparsely pubescent, 5 to $8 \mathrm{~mm}$. high : rays 8 to 18,1 to $1.5 \mathrm{~cm}$. long: disk yellow, 1 or $2 \mathrm{~cm}$. broad: lobes of disk-corollas glabrous : pappus none.

Plentiful in the San Bernardino Valley, thence south to western San Diego Co. and Lower California, east into Arizona, and north to Death Valley: very common on benches and low mountains of the Colorado Desert, probably much less common on the Mohave but not rare at Newberry and collected near Death Valley by Coville: chiefly in the Lower Sonoran Zone. In Lower California this plant is known as Incienso because of the custom of collecting and burning the resinous exudation as an incense in the churches. ${ }^{28}$ This cognomen may well be accepted as its common name.

4. E. eriocephala Gray, Proc. Am. Acad. viii. 657 (1873). Simsia canescens Gray, Pl. Fendl. 85 (1849); not Encelia canescens Cav., Ic. i. 45 (1791). Desert Sunflower.

Annual, from 1 to fully $6 \mathrm{dm}$. high, usually with several erect branches from the base: herbage hirsute with long white hairs, rarely glabrate above: leaves mainly toward the base, 3 to $10 \mathrm{~cm}$. long, ovate or lanceolate to obovate, acute, narrowed to the short margined petiole, few-toothed or entire: heads 1 to several, on short peduncles terminating long leafless branches or more numerous in an open panicle: involucre 7 to $10 \mathrm{~mm}$. high, its lanceolateacuminate bracts green but the margins and base very white with a long villous pubescence: rays variable, commonly 12 to 16 in number and 1 or $2 \mathrm{~cm}$. long: pappus of 2 stout awns, continuous

28 Brandegee, Zoe i. 83 (1890). 
with the margins of the achenes, much thickened below and about as long as the disk-corollas.

Very common in sandy soil of the Lower Sonoran Zone on both the Colorado and Mohave deserts, where large areas are rendered brilliant by its showy yellow heads in good seasons; east into Arizona and Nevada.

5. E. viscida Gray, Proc. Am. Acad. xi. 78 (1876).

Somewhat branching, 3 to $6 \mathrm{dm}$. high, leafy up to the usually short simple peduncles: herbage viscid-glandular and hirsutely villous : cauline leaves 6 to $8 \mathrm{~cm}$. long, ovate to oblong, obtuse or acute, clasping, entire or more often sharply toothed: involucre 12 to $15 \mathrm{~mm}$. high and fully as broad: achenes narrowly cuneate, truncate between the awns.

Near Campo in the mountains of southern San Diego Co., Palmer, ace. to Gray, Parish, no. 242 ; Abrams, no. 3633, Brandegee; Lower California. Lower leaves and base of stem unknown.

\section{VERBESINA L.}

Ours erect branching annuals with simple dentate or entire leaves. Heads on more or less elongated peduncles. Involucre hemispheric or campanulate, its ovate to linear bracts in several series. Receptacle usually conical; its bracts concave, folded about the outer edge of the achenes. Both disk and ray yellow in our species. Achenes strongly compressed laterally, usually oblong or obovate, winged on each edge. Pappus of two awns, one to each edge of the achene.

Leaves sessile, green on both sides.

..1. V. dissita.

Leaves petioled, canescent at least beneath.

Disk-achenes broadly winged, pubescent: var. exauriculata of

2. V. encelioides.

Disk-achenes narrowly winged, glabrate.

3. V. australis.

1. V. dissita Gray, Proc. Am. Acad. xx. 299 (1885).

Tall, probably from a suffrutescent perennial base: herbage green and nearly glabrous, only the leaves obscurely scabrous and the involucres cinereous: leaves thin-membranous, remote, mostly opposite, sessile or short-petioled, ovate, serrate or entire, 4 to 8 $\mathrm{cm}$. long: heads short-peduncled, few in a terminal panicle: in- 
volucre about $1 \mathrm{~cm}$. high, equalling or shorter than the disk; its bracts linear-lanceolate, acute or the outer very obtuse: achenes nearly glabrous, the body oblanceolate, $1 \mathrm{~cm}$. long; wings narrow at base but becoming very broad above, the whole fruit therefore obovate: pappus-awns slender, longer than the body of the achene, the base coalescent with the wing.

Near Arch Beach, Orange Co., May, 1903, Mrs. M. F. Bradshaw; Dobbs Camp, Mill Creek Cañon, San Bernardino Mts., at $2200 \mathrm{~m}$. alt. (Transition Zone), Rev. Geo. Robertson (det. by Dr. B. L. Robinson); Sauzal, Lower California, Orcutt ; first collected at All Saints Bay (Ensenada), Lower California, by Orcutt, no. 1233.

2. V. encelioides exauriculata Rob. \& Greenm., Proc. Am. Acad. xxxiv. 544 (1899).

Three to $6 \mathrm{dm}$. high, from a straight taproot, cinereous or canescent: leaves whitened below with appressed hairs, green and somewhat scabrous above, narrowly to broadly ovate or cordate; the blade mostly 5 to $10 \mathrm{~cm}$. long, commonly dentate with salient teeth; petioles slender, or those of the upper leaves provided on each side with a wing which broadens at base into a semi-ovate auricle : outer involucral bracts oblong or lanceolate, about $1 \mathrm{~cm}$. long: rays 12 to 15 , deeply tridentate, about $1 \mathrm{~cm}$. long, often orange-colored: achenes rather densely pubescent, obovate, broadly winged; the wings becoming corky-thickened, obtuse at apex: awns of the pappus short, setiform.

Fairly common on low ground from San Fernando, Los Angeles, and San Bernardino to Colorado and Mexico. Probably an introduced plant with us. This variety ean be distinguished from typical $V$. encelioides only by the complete or partial reduction of the auriculate expansions at the base of the petiole and by the broad summit of the wings to the achenes. Specimens with none of the petioles at all dilated at base have involucres considerably longer than the disk.

3. V. australis (H. \& A.) Baker, in Mart., Fl. Bras. vi. pt. 3, 215 (1884). Ximenesia microptera DC., Prodr. v. 627 (1836). X. australis H. \& A., in DC., l. c. vii. 291 (1838). Not Verbesina microptera DC., Prodr. v. 616 (1836). 
Herbage cinereous throughout except the upper surface of the leaves, this green and only strigose-pubescent: leaves ovate, saliently toothed, the larger ones $10 \mathrm{~cm}$. or more long, the petioles of only the narrow uppermost ones auriculate-dilated at base: involucral bracts lanceolate, acute, 8 to $10 \mathrm{~mm}$. long, shorter than the disk: ligules orange-colored, tridentate, 1 to $1.5 \mathrm{~cm}$. long: achenes narrowly obovate, sparsely pubescent, glabrate; wings narrow or almost none except at the summit: awns of the pappus short, setiform.

Oxnard, Ventura Co., 1901, Davy, no. 7818; Mexico, Chile, Argentine, etc.

\section{COREOPSIS L.}

Mostly herbaceous plants, a few species shrubby. Heads medium-sized or large, long-peduncled, solitary or in loose cymes. Involucre double; bracts of the inner series 8 to 12 , erect, membranous; bracts of the outer series 5 to 8 , narrow, loose and foliaceous. Flowers of both ray and disk yellow in our species and the ray-flowers either pistillate or neutral. Achenes flat to meniscoidal, linear-oblong to oval, the margins either smooth or eiliate or winged. Pappus none or of bristles, scales, or teeth proceeding from the angles of the achene.

The species here described all fall into the section Leptosyne, characterized by a single character, namely, a thickened or hairy ring around the upper part of the corolla-tube of the disk-flowers. As a genus, Leptosyne was first assigned the additional character of possessing pistillate and usually fertile ray-flowers, but Dr. Gray, in extending it to include his genus Pugiopappus, in which the ray-flowers are often neutral and usually infertile, left only the annular swelling of the disk-corollas to separate Leptosyne from Coreopsis. There are, moreover, certain species, described under Leptosyne, ${ }^{29},{ }^{30}$ in which the ray-flowers are fertile and the disk-corollas destitute of the annulus. In L. Mexicana Gray, ${ }^{31}$ the ray-flowers have fertile achenes and the disk-corollas a mere trace of the annular swelling. Since there is no habital differ-

29 L. insularis Brandegee, Eryth. vii. 5 (1899).

30 L. pinnata Rob., Proc. Am. Acad. xxvii. 176 (1892).

31 Gray, in Wats., Proc. Am. Acad. xxii. 429 (1887). 
ence of importance, I follow Bentham \& Hooker and Hoffmann ${ }^{32}$ in disposing of Leptosyne as a section of Coreopsis.

Annuals: disk-achenes either thickened and corky-winged or conspicuously ciliate.

Pappus none: disk-achenes corky-winged.

1. C. Douglasii.

Pappus of 2 linear awns: mature disk-achenes ciliate with long hairs.

Outer bracts of the involucre linear. 2. C. Bigelovii.

Outer bracts of the involucre broadly ovate 3. C. calliopsidea.

Perennials: achenes glabrous, flat, narrowly winged.

Peduncles scattered, $1.5 \mathrm{dm}$. or more long: rays $3 \mathrm{~cm}$. long

4. C. maritima.

Peduncles corymbosely clustered, mostly less than $1.5 \mathrm{dm}$. long: rays 2.5 to $3 \mathrm{~cm}$. long.

5. C. gigantea.

1. C. Douglasii (DC.) Hall, comb. nov. Leptosyne Douglasii DC., Prodr. v. 531 (1836). L. Californica Nutt., Trans. Am. Philos. Soc. ser. 2, vii. 363 (1841). L. Newberryi Gray, Proc. Am. Acad. vii. 358 (1868).

Stems scapose, 1.5 to $4 \mathrm{dm}$. high, simple and monocephalous, usually several from the slender taproot and ascending, sometimes few or solitary, then slender and erect: leaves mostly in a dense basal tuft, 3 to 10 (or 15) $\mathrm{cm}$. long, filiform-linear and entire or more eommonly 2 to 3 -parted into slender lobes: bracts of the outer involucre linear, 5 to $7 \mathrm{~mm}$. long; inner involuere of ovate scarious-margined bracts: rays commonly $1 \mathrm{~cm}$. long but much reduced in depauperate plants, yellow, or not infrequently white on the upper third: ring of disk-corollas usually distinctly bearded: achenes of both ray and disk obovate with broad wings which become corky in age, also corky-ridged down the inner face, rough with short rigid hairs: pappus represented by a minute cup-like border terminating the achene.

Plains and foothills almost throughout the Lower and Upper Sonoran zones of Southern California, particularly common west of the mountains, often beneath chaparral and then much reduced in size and delicate. Mar.-May. There is a seashore form, plentiful along the coast of San Diego Co., with short thick leaves in a dense basal cluster, stout stems, and large heads. It corre-

32 Hoffmann, in Engler \& Prantl, Natürl. Pflanzenf. iv. abt. 5, 243 (1890). 
sponds to the seashore forms of Chaenactis glabriuscula, Baeria chrysostoma, etc.

2. C. Bigelovii (Gray) Hall, comb. nov. Pugiopappus Bigelovii Gray, Pacif. R. Rept. iv. pt. 5, 104 (1857). P. Breweri Gray, Proc. Am. Acad. viii. 660 (1873). Leptosyne Bigelovii Gray, Syn. Fl. 1. pt. 2, 300 (1884).

Stems several or numerous, from an annual root, 2 to $4 \mathrm{dm}$. high except in depauperate specimens, commonly simple and seape-like but often branching and leafy below : leaves 5 to $10 \mathrm{~cm}$. long, 2 to 3-parted into linear lobes : outer involucre of narrowly linear loose bracts; inner involucre 8 to $10 \mathrm{~mm}$. high, its bracts broadly ovate, erect: rays 1 to $2 \mathrm{~cm}$. long: ring of disk-corollas beardless : ray-achenes with narrow eallous-winged margin; diskachenes oblong, the villous marginal hairs conspicuous: pappuspaleae 2, broadly oblong, erose-margined, half as long as the achene.

Western portion of the Desert Area and warm places west of the mountains in northern Los Angeles Co. and in Ventura and Santa Barbara counties: Palm Springs, on the Colorado Desert, and Morongo, on the Mohave Desert, north to Kern and Inyo counties; particularly abundant on gravelly slopes around Antelope Valley in Apr. and May; the westernmost station is probably Zaca Lake Forest Reserve, Santa Barbara Co., Miss Eastwood, no. 585.-Rays commonly deep yellow throughout but in specimens from Elizabeth Lake they are intense yellow on the lower half, pale yellow on the upper half, the difference being especially noticeable in age when the upper portion fades to white.

3. C. calliopsidea (DC.) Gray, Bot. Mex. Bound. 90 (1859). Agarista calliopsidea DC., Prodr. v. 569 (1836). Leptosyne calliopsidea Gray, Syn. Fl. i. pt. 2, 300 (1884).

Branching and leafy below, 3 to $6 \mathrm{dm}$. high: bracts of the outer involucre broadly ovate, conspicuously shorter than the oblong-ovate inner ones: rays cuneate-obovate, commonly $2 \mathrm{~cm}$. long and $1 \mathrm{~cm}$. wide, 15 to 20 -nerved: ring of the disk-corolla pubescent: achenes of the ray and outer disk-flowers oval, flat, glabrous; central achenes cuneate-oblong, long-villous on the margins and inner face: pappus-paleae 2, linear, nearly as long as the achene. 
On the Mohave Desert at the base of Fremonts Peak, San Bernardino Co., Hall \& Chandler, nos. 6868, 6869; Mohave Station, Kern Co., Pringle (in a dwarf form); between Manzana and Cuyama, in southeastern San Luis Obispo Co., Miss Eastwood; north to middle California.

4. C. maritima (Nutt.) Hook. f., Bot. Mag. t. 6241 (1876). Tuckermannia maritima Nutt., Trans. Am. Philos. Soc. ser. 2, vii. 363 (1841). Leptosyne maritima Gray, Proc. Am. Acad. vii. 358 (1868).

Stems fleshy-herbaceous, spreading, much branched, the plant 3 to $8 \mathrm{dm}$. high: leaves two or three times pinnately divided into linear lobes; these .5 to $1 \mathrm{~cm}$. long in the upper leaves, often $3 \mathrm{~cm}$. in the lower: heads large (disk 2.5 or $3 \mathrm{~cm}$. broad), on naked peduncles $1.5 \mathrm{dm}$. or more long: outer involucre of ovate or oblong herbaceous bracts; inner involucre of longer oblong bracts which approach the rays in texture and color: rays 16 to 20 , about $3 \mathrm{~cm}$. long: ring of disk-corollas beardless : achenes oblong with thin narrow wings, glabrous: pappus commonly none, rarely 1 or 2 short awns.

Coast of San Liego Co. and northern Lower California, and on the adjacent islands. Cultivated for its handsome foliage and showy flowers.

5. C. gigantea (Kell.) Hall, comb. nov. Leptosyne gigantea Kell., Proc. Calif. Acad. iv. 198 (1873).

Robust fleshy-woody trunks erect, 3 to 12 or even $20 \mathrm{dm}$. high and often $1 \mathrm{dm}$. or more thick: primary branches distant, horizontal or ascending, leafy only towards the ends: leaf-divisions filiform, from very short to $5 \mathrm{~cm}$. or more long, varying between these extremes from year to year on individual plants: heads medium-sized (disk about $2 \mathrm{~cm}$. broad) on cymosely clustered peduncles $1.5 \mathrm{dm}$. or less long: outer involucre of oblong or lanceolate bracts; inner bracts longer, oblong, yellowish, the midnerve prominent toward the base : rays 10 to $16,2.5$ to $3 \mathrm{~cm}$. long: ring of disk-corollas beardless: achenes narrowly oblong, margined, glabrous : pappus none.

Near the coast from Los Angeles Co. to San Luis Obispo Co. (probably further north) and on the adjacent islands. I have 
seen the following: Dume Point, Los Angeles Co., Mar., 1898, Barber, no. $372 ;^{33}$ foothills east of Hueneme, Ventura Co., 1894, Wright; Point Sal, Santa Barbara Co., 1892, Jared, and May, 1896, Miss Eastwood; Santa Cruz Island, 1886, Greene, and 1888, Brandegee; Santa Catalina, Santa Barbara, and San Nicolas islands, Mrs. Trask; Santa Rosa Island, Harford; San Miguel Island, 1903, Beck. Labels accompanying Mrs. Trask's specimens state that the heads are sometimes discoid and that the rays, when present, are sometimes pale yellow at the tip.

The longevity of plants grown in the Botanic Garden at Berkeley is 4 to 6 years. When removed from the ground and placed in a dry room, they continue to send forth leaves and flowers for several weeks, this being possible because of the thick stems which apparently act as storage reservoirs.

\section{BIDENS L. BEgGar Ticks.}

Herbs with toothed, pinnatifid, or pinnately compound opposite leaves. Heads many-flowered, solitary racemose or panicled. Ray-flowers mostly neutral or wanting. Involucre double, the inner bracts membranous and more numerous than the outer ones. Chaff of the receptacle flat or merely concave. Disk-achenes obcompressed, or slender and 4-sided, crowned with 2 to 4 rigid persistent retrorsely barbed awns.

Leaves simple: rays showy, yellow

1. B. expansa.

Leaves compound: rays none or inconspicuous.

2. B. pilosa.

1. B. expansa Greene, Pitt. iv. 266 (1901). B. speciosa Parish, Zoe v. 75 (1900); not B. speciosa Gardn., in Hook. Lond. Journ. Bot. iv. 126 (1845). Water Daisy.

Perennial by stolons, the stems decumbent at base but soon erect and 1 to $12 \mathrm{dm}$. long: herbage glabrous throughout: leaves 1 to $2 \mathrm{dm}$. long, lanceolate, acuminate, narrowed to the connate base, evenly sub-serrate with short callous-tipped teeth : heads on stout peduncles, erect in flower, nodding in fruit: outer involucral bracts 4 to 8 , linear-oblong, from nearly equalling to much exceeding the disk, serrate when foliaceous; inner bracts 8 ,

33 First reported from Dume Point, or "'Point Dumas," by Dr. H. E. Hasse, Bull. Torr. Club xxiv. 448 (1897). 
broadly ovate, membranous, striate with dark lines: rays about 8 , golden yellow, 2 or $3 \mathrm{~cm}$. long by about $1 \mathrm{~cm}$. broad, entire or minutely toothed at apex : mature achenes black, flat, 1-nerved on each side, retrorsely barbed on the margins: pappus of 2 retrorsely barbed awns, $3 \mathrm{~mm}$. long, and often a third awn half as long.

A handsome aquatic, blossoming in the summer and autumn, fairly common in shallow streams from San Bernardino to Los Angeles and perhaps further north: near San Bernardino, Parish; no. 4598; near Riverside, Koethen; Pomona, Baker, no. 3727; Los Angeles River and Oak Knoll, Braunton, nos. 576, 665, 728; Ballona Marshes, Chandler, no. 2029.

2. B. pilosa L., Sp. Pl. 832 (1753).

Annual, 5 to 10 or $15 \mathrm{dm}$. high, usually branched from the base: herbage from pilose-pubescent to nearly glabrous: leaves pinnate; leaflets 3 to 5 , ovate, serrate, 1.2 to $2.5 \mathrm{~cm}$. long: heads about $1 \mathrm{~cm}$. broad, scattered, the peduncles commonly 2 to $6 \mathrm{~cm}$. long: rays usually none, small and yellowish-white when present: achenes linear, tetragonal, about $1 \mathrm{~cm}$. long, marked with scattered ascending barbs: pappus of 2 to 4 retrorsely barbed awns.

A native of the tropies; frequent in Southern California as a weed.

\section{MELAMPODIUM L.}

Herbaceous plants with ample opposite leaves. Heads medium-sized, in leafy-bracted cymes or panicles. Outer involucre of several loose often foliaceous bracts; inner involucre of smaller bracts each completely enclosing a marginal achene with which it is deciduous as a pericarp-like accessory covering. Rays yellow or white. Disk yellow, of hermaphrodite-sterile flowers. Pappus none.

1. M. perfoliatum (Cav.) HBK., Nov. Gen. \& Spec. iv. 274 (1820). Alcinia perfoliata Cav., Ic. i. 10, t. 15 (1791).

A coarse widely branched annual, commonly 10 or $12 \mathrm{dm}$. high: leaves $2 \mathrm{dm}$. or less long, scabrous, broadly ovate, acute, contracted below as if into a winged petiole, connate around the stem in pairs, the margins dentate: heads on slender peduncles: bracts of the outer involucre 1 to $1.5 \mathrm{~cm}$. long, united at base. 
Waste places at Los Angeles, where it has been introduced from Mexico.

Gymnolomia multiflora (Nutt.) B. \& H. A few specimens have been collected at Los Angeles by Dr. Davidson, and near Santa Monica by Dr. Hasse. At neither place has the species reappeared and it ean therefore scarcely be admitted to our flora $^{34}$ Herbaceous branched perennial, 3 to $6 \mathrm{dm}$. high, with a rough herbage: leaves linear or lanceolate, mostly entire: rays showy, yellow: achenes smooth, without pappus. An extreme form with very narrow revolute leaves and slender stems, segregated as $G$. Nevadensis by A. Nelson, ${ }^{35}$ occurs in Southern Nevada and reaches the Argus Mts. of Inyo Co., California, where collected by Purpus, no. 5025.

\section{Tribe 6. MADIEAE. Tarweed Tribe.}

53. MADIA Mol. TARWEED.

Erect annual and perennial herbs (one Mexican species shrubby), often glanular-viscid and heavy-scented. Leaves alterrate (at least the upper), entire or serrate. Flowers yellow. opening in the evening and closing before noon of the next day. Involucre angled by the carinate or almost conduplicate bracts, these in 1 series, each completely enfolding its ray-achene with which it is deciduous, and with a free moderately long or short tip. Receptacle flat or convex, its bracts in a single row between ray and disk-flowers and often united into a cup. Rays few to many, pistillate, the ligules 3-lobed. Disk-flowers 1 to many, perfect, but their achenes mostly abortive. Ray-achenes laterally compressed, oblique, with narrow backs, rarely beaked. Pappus, in our species, none.

Rays short and inconspicuous: receptacle glabrous or nearly so.

Disk-flowers 5 to 20 .

Plant stoutish, viscid-glandular: heads clustered: disk-achenes angular .1. M. sativa.

Plant slender, moderately glandular: heads scattered: disk-achenes flat

2. M. dissitiflora.

Disk-flower solitary

4. M. exigua.

Rays showy: receptacle fimbrillate-hirsute 3. M. elegans.

34 Davidson, Eryth. i. 61 (1893).

35 Bot. Gaz. xxxvii. 271 (1904). 
1. M. sativa Molina, Chile ed.1., 136 (1782). Chile TarWEED.

Usually robust, 3 to $6 \mathrm{dm}$. high: herbage pubescent with slender hairs and beset with pedicillate very viscid glands, illscented: leaves from broadly lanceolate to linear: heads shortpeduncled or sessile, disposed in the upper axils and in small clusters terminating short branches : involucre 8 to $12 \mathrm{~mm}$. high; its bracts hispid: ray-flowers 5 to 12 , with pale-yellow ligules about $4 \mathrm{~mm}$. long: cup of receptacle campanulate and enclosing many disk-achenes, these cuneate-oblong and somewhat 4-angled, being prominently 1-nerved on each face: ray-achenes somewhat falcate-obovate, either with or without an obvious nerve on each side: receptacle either glabrous or minutely hirsute.

At low altitudes from the Cuyamaca Mts., San Diego Co., north to Oregon; very common in some districts, rare or wanting in others. Doubtless introduced from Chile.

2. M. dissitiflora (Nutt.) T. \& G., Fl. ii. 405 (1843). Madorella dissitiflora Nutt., Trans. Am. Philos. Soc. ser. 2, 387 (1841).

Very slender, 2 to $6 \mathrm{dm}$. high, simple or loosely branched: herbage pubescent but moderately if at all viscid, at least below : heads loosely racemose or more often paniculate, the peduncles seldom very short: involucre 5 to $8 \mathrm{~mm}$. high : cup of receptacle ovoid but not closed, containing few disk-flowers: ray-flowers 5 to 8 , the sulphur-yellow ligules 3 or $4 \mathrm{~mm}$. long: disk-achenes short and broad, flat, not angled but with one or both of the faces more or less prominently 1-nerved: receptacle glabrous.

In rather moist soil of the Upper Sonoran Zone from San Diego Co. (Witch Creek, Alderson; Noble Mine, Chandler, no. 5489 ) to Oregon. Some specimens from near Los Angeles combine the characters of $M$. dissitiflora and $M$. sativa in a very perplexing manner, indicating that these two species are perhaps confluent.

3. M. elegans Don., in Lindl., Bot. Reg. t. 1458 (1831). Madaria elegans DC., Prodr. v. 692 (1836). Common Madia.

Stout, 5 to $15 \mathrm{dm}$. high: herbage, particularly above, viscid with short gland-tipped hairs, the inflorescence more or less hirsute with white hairs: lower leaves linear, short-hirsute; 
upper leaves much reduced in size, linear-lanceolate: heads in a corymbose panicle: receptacle convex, fimbrillate-hirsute: rays 12 to 15 ; the ligules 8 to $16 \mathrm{~mm}$. long, yellow or with a red spot at base: achenes flattish, light brown to almost black, smooth.

Common at middle and lower altitudes in the mountains (Transition and Upper Sonoran Zones), from Palomar, San Diego Co., to Oregon.

Var. hispida (DC.) Hall, comb. nov. Madaria corymbosa $\beta$ ? hispida DC., Prodr. v. 692 (1836). Madia hispida Greene, Pitt. ii. 217 (1891). A slender form with long almost hispid spreading hairs and nearly destitute of the black tack-shaped glands: stems 3 to $6 \mathrm{dm}$. high: lower leaves opposite, in rather remote pairs: rays clear yellow.-Upper Sonoran Zone: Tehachapi, Jun., 1899, Greene; near Fort Tejon, Kern Co., Coville \& Funston, no. 1172, and Hall, no. 6274: north along both the Coast Ranges and the Sierra Nevada Mts. to middle California.

4. M. exigua (Sm.) Greene, Eryth. i. 90 (1893). Sclerocarpus exiguus Sm., in Rees' Cycl. xxxi. no. 3 (1816). Harpaecarpus exiguus Gray, Bot. Mex. Bound, 101 (1859). Madia filipes Gray, Proc. Am. Acad. viii. 391 (1872), and ix. 189 (1874).

Stem slender, paniculately branched to nearly simple, the whole plant commonly 1 to $2 \mathrm{dm}$. high : herbage viscid-glandular, sweet-scented: leaves linear, entire: heads on naked filiform peduncles: involucre $3 \mathrm{~mm}$. high; its bracts 4 to 8 , lunate and strongly carinate, the free tip minute: ligules inconspicuous: bracts of the receptacle united: disk-flower only one: ray-achenes laterally compressed, obovate-lunate, pointed by a small disk.

Mostly in the Lower Transition Zone; frequent at middle and lower altitudes from San Diego Co. northward to British Columbia.

\section{HEMIZONELLA Gray.}

Low annual herbs, hirsute throughout or the stems glabrate. Leaves linear and entire, mainly opposite. Involucre of 4 or 5 bracts, which are broad on the back, the margins infolded for their whole length and completely enclosing the obcompressed incurved ray-achenes. Bracts of the receptacle united to form 
a 3 to 5 -toothed cup encircling the solitary (or rarely 2 to 4 ) infertile disk-achene. Flowers minute, yellow. Pappus none.

1. H. minima Gray, Proc. Am. Acad. ix. $189^{\circ}$ (1874). Hemizonia minima Gray, l. e. vi. 548 (1865). Harpaecarpus minimus Greene, Fl. Fr. 417 (1897).

Plant depressed, seldom over $5 \mathrm{~cm}$. high, branched: seedleaves oval, the others linear, $1 \mathrm{~cm}$. or less long: heads in small glomerules, sessile or on very short peduncles: involucre 2 or 3 mm. high: ray-achenes obovate, rounded at summit, either beakless or with a minute inflexed apiculation.

Strawberry Valley, San Jacinto Mt., Jepson, and Hall, no. 1802 ; Antelope Valley, Davy, no. 2462; and in the Sierra Nevada Mts., especially on the eastern slope. To be expected anywhere in the Transition Zone of our district.

Var. parvula (Gray) Hall, comb. nov. Hemizonia parvula and H. Durandi Gray, Proc. Am. Acad. vi. 549 (1865). Hemizonella parvula and H. Durandi Gray, l. e. ix. 189 (1874). Harpaecarpus parvulus Greene, Fl. Fr. 416 (1897). Ray-achenes tipped with a short incurved beak: stems sometimes $15 \mathrm{~cm}$. long and the earliest heads slender-peduncled, but plants frequently as depressed as in the species.-Transition Zone : Cuyamaca Lake, San Diego Co., Jul. 17, 1906, Mrs. Brandegee; San Bernardino Mts., Parish, nos. 2400, 2086; Wilsons Peak, San Gabriel Mts., McClatchie; the common form in the Sierra Nevada Mts. and Oregon.

An extensive series of specimens, mostly from the Sierra Nevadas, exhibits all gradations in the ray-achenes from those with smooth rounded summits to those with conspicuous inflexed beaks. Of the specimens seen from Southern California only those from Cuyamaca are strictly typical of var. parvula, but it reappears just over the line in Kern Co. (Mt. Pinos, Hall, no. 6431.)

\section{HEMIZONIA DC. TARWEED.}

Mostly annual or biennial herbs (one of our species somewhat woody) with at least the upper leaves alternate. Flowers yellow or white, in mostly numerous heads. Receptacle flat, its bracts deciduous. Ray-achenes obcompressed with broad back, 
thick and turgid (never laterally compressed with narrow back), each partially enclosed by the lower part of its involucral bract. Disk-achenes sterile.

A.-Receptacle with a cup-like circle of bracts between disk and ray: leaves (never spinose) destitute of truncate glands.

Pappus none: flowers yellow.

Leaves entire

1. H. Wheeleri.

Lower leaves pinnately divided

3. H. corymbosa.

Pappus of disk-achenes present.

Flowers yellow: leaves linear or broader.

Rays 8 to 20: disk-flowers as many or more.

Perennial: herbage not glandular: insular

2. H. Clementina.

Annuals: at least the involucres glandular.

Disk-achenes wholly sterile and with pappus of minute fimbriate scales or wanting

3. H. cormybosa.

Disk-achenes well formed and with pappus of oblong obtuse pubescent or erose paleae.

Beak of ray-achenes curved: some of the cauline leaves pinnatifid

4. H. paniculata.

Beak of ray-achenes straight: cauline leaves all entire

5. H. floribunda.

Rays mostly 5 (3 to 8 ): disk-flowers not over 10 .

Involucral bracts not carinate: heads on slender peduncles

6. H. Wrightii.

Involucral bracts carinate: heads mostly in small elusters

7. H. fasciculata.

Flowers white: leaves nearly filiform

8. H. tenella.

B.-Receptacle with chaffy bracts throughout; no cup-like circle between disk and ray: flowers yellow.

Leaves not spinose, the uppermost ones tipped with a truneate gland.

Rays 4 or 5 : leaves crowded on the branchlets.

9. H. virgata.

Rays 5 to 8: leaves seattered on the branchlets. 10. H. Heermanni.

Leaves spinose and rigid (at least the upper): rays 25 to 40, 2-lobed.

Disk-pappus of 3 to 5 entire paleae or wanting.

11. H. pungens.

Disk-pappus of 8 to 12 paleae, fimbriate at the tip.

12. H. Fitchii.

1. H. Wheeleri Gray, Bot. Calif. i. 617 (1876). Madia tenella Greene, Pitt. iii. 167 (1897).

Slender, erect, 1.5 to $6 \mathrm{dm}$. high: stem simple or branching below, more or less cymosely branched above and bearing scattered heads of bright-yellow flowers; the eymes sometimes condensed (simple-stemmed and monocephalous only in depauperate plants) : herbage hirsute with spreading white hairs, the inflorescence glandular: leaves scattered (the lower opposite, the upper 
alternate), linear, rather obtuse, 3 to 6 or $7 \mathrm{~cm}$. long: involucre 5 to $7 \mathrm{~mm}$. high ; its bracts rounded on the back, the lower portion half-enfolding the ray-achenes: ray-flowers 5 to 13, usually 8; the 3-cleft ligules 4 to $8 \mathrm{~mm}$. long : bracts of the receptacle lightly united for two-thirds their length: ray-achenes with broad back and acute inner edge, therefore triangular in cross-section, broad at summit, pointed at base, $3.5 \mathrm{~mm}$. long, nearly black; diskachenes infertile: pappus none.

A species of the arid Transition Zone: San Jacinto Mt., Hall, nos. 2268, 2662, and May, 1899, without number; Bluff Lake, San Bernardino Mts., Williams; Little Green Valley, San Bernardino Mts., Geo. R. Hall; South Fork Santa Ana River, Mrs. Wilder, no. 313; Potrero, Mt. Pinos, Grinnell; Southern Sierra Nevada from Greenhorn Range, Kern Co., to Olancha Peak and Mineral King, Tulare Co., Hall \& Babcock, nos. 5103, 5128, 5206, $5212,5275,5276,5399,5643$.

With the habit and whole aspect of a Madia, this species combines the technical achenial and involucral characters of Hemizonia. It was originally collected by Dr. Rothrock at Monache Meadows, etc., on the west slope of Olancha Peak, in which district it is very plentiful in loose granitic soil and exhibits a remarkable range of variation in habit, pubescence, and number of rays. Dr. Coville ${ }^{36}$ has already pointed out that the outer receptacular bracts are not distinct, as originally described; and although Dr. Greene states that they are distinct in his Madia tenella, I have yet to see specimens in which they are not united, although easily torn apart while being examined.

2. H. Clementina Brandegee, Eryth. vii. 70 (1899). $H$. Streetsii Gray, Syn. Fl. i. pt. 2, 451 (1886) in part, not of Proc. Am. Acad. xii. 162 (1877).

Plant probably a half-shrubby perennial, 3 to $6 \mathrm{dm}$. high: stems many, at length much branched and leafy to the numerous cymosely crowded heads: herbage sparsely hirsute, not conspicuously glandular but more or less viscid above: leaves rigid, linear, entire or with a few short teeth: rays 12 to 20 ; disk-flowers numerous: ray-achenes rugose-tuberculate, stipitate, beaked: pappus-paleae of disk-achenes about 10, subulate-linear, unequal.

36 Contr. U. S. Nat. Herb. iv. 133 (1893). 
Santa Catalina Island, Nevin \& Lyon, Brandegee, Mrs. Trask; San Nicholas and Santa Barbara Islands, Mrs. Trask; San Clemente Island, Brandegee.

3. H. corymbosa (DC.) T. \& G., Fl. ii. 398 (1843). Hartmannia corymbosa DC., Prodr. v. 694 (1836). Zonanthemis corymbosa Greene, Fl. Fr. 425 (1897).

Cymosely and widely branched, 3 to $5 \mathrm{dm}$. high: herbage hirsute-pubescent and glandular: radical and lower leaves pinnately divided into linear lobes, the upper and those of the flowering branches linear and entire: involucre broadly hemispheric, 6 to $8 \mathrm{~mm}$. high : rays 12 to 20 , oblong-cuneate, 5 to $8 \mathrm{~mm}$. long, 3 or 4-toothed : pappus of the sterile disk-achenes of minute fimbriate-bristly scales, or none: ray-achenes with a short upturned beak on the inner side at apex.

Gaviota, Santa Barbara Co., Mrs. Curran, and northward along the coast. Dr. Palmer's no. 237 is labeled "District of Mohave R.," but this is certainly erroneous. It was probably gathered near San Simeon, San Luis Obispo Co., ace. to Mrs. Brandegee.

4. H. paniculata Gray, Proc. Am. Acad. xix. 17 (1883).

Diffusely branched above, 3 to $10 \mathrm{dm}$. high; the stem hirsute below, viscid-glandular above: cauline leaves narrowly oblong, laciniate-pinnatifid; those of the numerous short branchlets crowded, erect, entire: ray-flowers usually 8 ; their achenes rugose or pitted on the back, and with short upturned beak at summit of inner angle: disk-achenes usually about 13 (11 to 20), pubescent; their 8 to 10 oblong pappus-paleae equalling the proper tube of the corolla and conspicuously pubescent or even erose at the summit.

On bench lands and plains of the Upper Sonoran Zone; common at a few places in Southern California: Santa Barbara, Pasadena, San Bernardino, Riverside, San Jacinto, San Diego, Santa Rosa Island.

5. H. floribunda Gray, Proc. Am. Acad. xi. 79 (1876).

A stout erect annual, $6 \mathrm{dm}$. or more high, the very leafy stem terminating in an elongated raceme or racemose panicle: herbage minutely glandular but not hirsute: cauline leaves linear, 1 to 3 
cm. long, entire: ray-achenes about 20 , in more than one series, somewhat tuberculate-rugose, with very short straight beak: pappus-paleae of the numerous disk-achenes 5 to 8 , shorter than the proper tube of the corolla, acute, conspicuously hirsute.

Southern part of San Diego Co.: Palmer, no. 177; Cleveland.

6. H. Wrightii Gray, Proc. Am. Acad. xix. 17 (1883). Deinandra Wrightii Greene, Fl. Fr. 424 (1897).

Paniculately branched above, 2 to 6 or $9 \mathrm{dm}$. high: herbage sparsely hirsute, at least below, the inflorescence glandular and sweet-scented: lower leaves oblanceolate, with few and remote short lobes or teeth, narrowed to a petiole; upper leaves reduced to bracts of the inflorescence, oblong with broad sessile base, obtuse, mostly $5 \mathrm{~mm}$. or less long, entire : heads solitary, terminating the numerous short branchlets: involucral bracts covered with stipitate glands and usually somewhat hirsute, the midrib not obviously thickened: ray-achenes black when mature, rugose, beaked on the inner angle, short-stipitate: pappus-paleae of diskachenes lacerate at summit.

First collected about San Bernardino; now known also from near San Jacinto, at altitudes of 450 to $1600 \mathrm{~m}$., from Riverside, where it covers large areas in the foothills, and from Antelope Valley. Also collected in the San Joaquin Valley where it is ap. parently rather common.

H. Kelloggir Greene, Bull. Torr. Club x. 41 (1883) is perhaps not specifically distinet from $H$. Wrightii, differing only in its pappus-paleae, some or all of these being united to near their summits. It has been collected near Pasadena by Grinnell, acc. to Abrams.

7. H. fasciculata (DC.) T. \& G., Fl. ii. 397 (1843). Hartmannia fasciculata DC., Prodr. v. 693 (1836). Deinandra fasciculata Greene, Fl. Fr. 424 (1897). D. simplex Elmer, Bot. Gaz. xxxix. 48 (1905).

Paniculately branched above the base, 2 to $6 \mathrm{dm}$. high: herbage sparsely hirsute and hispid, or disposed to be nearly glabrous above: radical leaves pinnately parted, 4 to $8 \mathrm{~cm}$. long; stemleaves linear to oblanceolate, laciniate-pinnatifid, few-toothed, or entire: those of the branchlets shorter and mostly entire: heads 
fascicled in rather dense small clusters, normally with 5 rays and 6 disk-flowers: bracts of the involuere glabrous or glandularhispidulous, earinate by a thickened midrib, those of the receptacle slightly united: corolla-lobes pubescent: ray-achenes smoothish or transversely rugose, with a very short beak; diskachenes with a pappus of 6 to 10 linear paleae some of which are toothed or lacerate at tip.

On mesas throughout Southern California except on the desert, north to San Francisco Bay; common, especially toward the coast and on the islands.

Var. ramosissima (Benth.) Gray, Syn. Fl. i. pt. 2, 310 (1884). H. ramosissima Benth., Bot. Sulph. 30 (1844). More diffuse : heads less fascicled or all scattered.-Same range as the species but less common.

8. H. tenella (Nutt:) Gray, Proc. Am. Acad. ix. 191 (1874). Osmadenia tenella Nutt., Trans. Am. Philos. Soc. ser. 2, vii. 392 (1841). Calycadenia tenella T. \& G., Fl. ii. 402 (1843).

Slender, usually 1.5 to $3 \mathrm{dm}$. high : herbage sparsely hispid, minutely glandular above: leaves very narrowly linear, acute, mainly alternate, at least the upper ones ciliate with long white hairs: heads subtended by a few bract-like leaves: involucre 5 to $7 \mathrm{~mm}$. high: ligules white with a transverse purple blotch across the midde (or pure white and whole herbage pale in albinoes), both ray and disk becoming reddish in age: ray-achenes 3 to 5, rugose and with an evident dorsal nerve: disk-achenes 5 , each with a pappus of 4 or 5 scabrous bristles as long as the corolla alternating with as many oblong lacerate-truncate paleae only half as long.

On dry plains and in sand-washes from Los Angeles to San Bernardino, Temecula, and San Diego; especially plentiful toward the coast.

9. H. virgata Gray, Bot. Mex. Bound. 100 (1859). Deinandra virgata Greene, Fl. Fr. 425 (1897).

Stem (3 dm. or more high) commonly branching at the middle into several virgate branches bearing numerous solitary or racemosely disposed heads on short lateral branchlets: herbage either glabrous or short-hirsute and glandular: branchlets 
crowded with linear leaves only about $2 \mathrm{~mm}$. long, those of the flowering branchlets ending in a truncate or somewhat saucershaped gland: involucral bracts stipitate-glandular on the back, the involute tip ending in a truncate gland: ray-flowers 4 or 5; disk-flowers 7 to 10 : pappus none.

Abundant in places on dry hills near the coast of San Diego Co., acc. to Parish; vicinity of San Diego, Brandegee, also W. S. Wright, no. 77; Poway, San Diego Co., Cleveland: middle California.-Often very glandular and strongly scented.

10. H. Heermanni Greene, Bull. Torr. Club ix. 15 (1882). Deinandra Heermanni Greene, Fl. Fr. 425 (1897).

Paniculately branched above, 3 to $10 \mathrm{dm}$. high: herbage pubescent and viseid, heavy-scented: leaves of the flowering branchlets small, scattered, each tipped with a minute truncate gland: involucral bracts beset with stalked glands and the apex truncateglandular: ray-flowers 5 to 8 ; disk-flowers 10 to 15 : ray-achenes with a somewhat conspicuous beak and stipe: pappus none.

Ojai, Ventura Co., Hubby; Santa Barbara, ace. to Gray; Tehachapi Pass, Parry; not rare in Kern Co.

11. H. pungens (H. \& A.) T. \& G., Fl. ii. 399 (1843). Hartmannia pungens H. \& A., Bot. Beech. 357 (1840). Centromadia pungens Greene, Man. Bot. Reg. S. F. Bay 196 (1894). Coмmon SPIKEWEED.

Freely branching, 3 to $10 \mathrm{dm}$. high : herbage yellowish-green, sparsely hirsute or hispid with spreading hairs, hardly viscid or glandular, sweet-scented: leaves (especially of the flowering branches) linear-subulate, spinose, entire; the lower and lowest pinnately parted into oblong lobes, or pinnatifid, the lobes or teeth spinosely or pungently tipped: heads commonly equalled or somewhat surpassed by the uppermost leaves: bracts of the receptacle cuspidate: ray-flowers 25 to 40 , their small ligules bifid: ray-achenes roughish, somewhat laterally 2-nerved on back: disk-achenes without pappus.

Abundant on low or alkaline ground throughout our district and northward through the San Joaquin Valley, often forming dense patches. 
Var. Parryi (Greene) Hall, comb. nov. Hemizonia Parryi Greene, Bull. Torr. Club ix. 16 (1882). Centromadia pungens Parryi Jepson, Fl. W. Mid. Calif. 532 (1901). Herbage usually minutely glandular: bracts of the receptacle thin, villous on the margin, obtuse or rarely acute but not at all pungent: sterile disk-achenes with 3 to 5 linear or subulate paleae as long as the corolla, these either smooth or with a few loose hairs.-Near Los Angeles and probably elsewhere toward the coast in Southern California; more common further north.

12. H. Fitchii Gray, Pacif. R. Rept. iv. 109 (1857). Centromadia Fitchii Greene, Man. Bot. Reg. S. F. Bay 197 (1894). Fitch's SPIKEWEED.

Diffusely branched, 2 to $9 \mathrm{dm}$. high: herbage dark, hirsute or villous with spreading hairs, more or less beset with stalked glands, ill-scented: leaves of the radical tuft pinnately parted into remote narrowly linear pungent lobes; cauline leaves linear and entire, tapering into a subulate or pungent tip ; those about the head spreading and star-like, exceeding the involucre: bracts of the involucre subulate; those of the receptacle pointless, soft, hairy : ray-achenes flattened laterally, nearly semicircular in outline, smooth: ligules of the 25 to 40 ray-flowers small, bifid: pappus of disk-achenes of 8 to 12 paleae as long as the corolla and hairy or fimbriate at the tip.

Quite abundant in a large wheat field on the Mohave River, Parish, no. 1426. Probably introduced from the north where it is more common.

H. LUzulaefolia DC. occurs in San Luis Obispo Co. and possibly within our limits. Annual: leaves linear, entire, the lower ones appressed-silky : receptacle chaffy throughout, its marginal bracts united: flowers white or pale yellow: pappus none.

\section{LAGOPHYLLA Nutt.}

Slender plants with mainly alternate entire leaves and rather small heads in leafy-bracted clusters. Bracts of the involucre about 5, thin-herbaceous; flat on the back, with margins at base infolded and completely enclosing their achenes with which they 
are deciduous. Receptacle small and flat, bearing in our species about 5 perfect disk-flowers, these surrounded by a single row of distinct chaffy bracts. Rays cuneate, palmately 3-cleft. Rayachenes obcompressed, obovate-oblong, smooth, nearly straight, pointless: disk-achenes slender, sterile. Pappus none. Bracts and achenes all deciduous at maturity.

1. L. ramosissima Nutt., Trans. Am. Philos. Soc. ser. 2, vii. 391 (1841).

Usually simple, strict throughout or paniculately very much branched above, 2 to $8 \mathrm{dm}$. high: leaves (especially the upper) silky-hirsute with soft hairs, the short ones subtending the heads densely villous-ciliate; lower leaves oblanceolate or linear-lanceolate, often narrowed at base to a slender petiole, 3 to $6 \mathrm{~cm}$. long, early deciduous: heads almost sessile, crowded on the leafy branchlets or the lower somewhat scattered; the involucre $6 \mathrm{~mm}$. high : rays barely exserted, pale yellow, changing through salmoncolor to saffron: fertile achenes earinately 1-nerved down the inner face.

Frequent in open places of the Upper Sonoran Zone from the Cuyamaca Mts. (Palmer, no. 181) and San Bernardino to Oregon and from the coast barely to the Desert Area (Mohave River, Parish.)

\section{LAYIA H. \& A.}

Vernal annuals with mainly alternate leaves and mediumsized heads on evident peduncles. Bracts of the involucre flattened on the back below, with abruptly dilated thin margins infolded so as to enclose the ray-achene, the tip flat. Ray-flowers 8 to 20 ; ligules yellow, white, yellow tipped with white, or roseate. Disk-corollas yellow, their lobes hirsute or villous. Receptacle broad and flat, with a row of thin bracts between ray and diskflowers and sometimes additional ones among the flowers. Rayachenes obcompressed, commonly glabrous, destitute of pappus, fertile. Disk-achenes usually pubescent, mostly sterile, in ours bearing a pappus of 5 to 20 bristles or awns (these rarely wanting in the last species). 
Pappus-bristles long-plumose or villous below.

Rays white or roseate, much surpassing the disk 1. L. glandulosa.

Rays bright yellow or eream-eolor (sometimes white-edged).

Inner hairs of pappus-bristles woolly and interlaced........2. L. elegans. Hairs of pappus-bristles all straight (no woolly inner ones).

Ligules inconspicuous, barely surpassing the disk: leaves mostly laciniate-dentate 3. L. hieracioides.

Ligules showy, much surpassing the disk: leaves all entire (rarely toothed) 4. L. graveolens.

Pappus of merely scabrous aristiform bristles or rarely wanting.

5. L. platyglossa.

1. L. glandulosa (Hook.) H. \& A., Bot. Beech. 358 (1840). Blepharipappus glandulosus Hook., Fl. Bor. Am. i. 316 (1834). Layia glandulosa rosea Gray, Bot. Calif. i. 368 (1876).

Commonly branching from the base, 1 to 4 or $6 \mathrm{dm}$. high: herbage rough with short hispid hairs among which (particularly near the heads) are few or numerous stipitate dark glands: leaves linear and entire or the lower commonly oblong and toothed to pinnatifid: involucre 8 to $10 \mathrm{~mm}$. high: rays showy, 1.5 to $2 \mathrm{~cm}$. long: pappus bright white, the bristles 10 to 12 , with straight hairs toward the base outside and woolly tangled hairs inside.

Common on foothills of the Upper Sonoran Zone throughout Southern California, extending barely to the edge of the Desert Area; north to British Columbia ; also from Idaho to New Mexico. Rose-purple and pure-white ligules sometimes occur on a single plant, as in specimens from near Pasadena (Greata, no. 319), and in others from Victorville ( Hall, no. 6208).

Var. heterotricha (DC.) Hall, comb. nov. Madaroglossa heterotricha DC., Prodr. v. 694 (1836). Layia heterotricha H. \& A., Bot. Beech. 358 (1840). Blepharipappus heterotrichus Greene, Pitt. ii. 245 (1892). B. glandulosus heterotrichus Jepson, Fl. W. Mid. Calif. 536 (1901). Rays 8 to 18 , white (rarely roseate): hairs of the pappus-bristles all straight and erect, there being no crisped or woolly inner ones.-Very common in the Upper Sonoran and Transition zones of Mt. Pinos, Ventura Co., Hall, nos. $6346,6493,6529$; Fort Tejon, Kern Co., Hall, no. 6280 ; north to Inyo and Mendocino counties. 
This variety passes directly into the species through forms (Hall, no. 6208, etc.) in which the inner erisped hairs of the pappus-bristles are present but very sparse. All of my specimens from Mt. Pinos and Fort Tejon, as well as a specimen in Dr. Davidson's herbarium without locality, and also Hall \& Babcock, no. 5043, from the Greenhorn Range, Kern Co., Purpus, no. 5017, etc., belong to a form with entire leaves and short ligules, these latter scarcely longer than broad ( 4 or $5 \mathrm{~mm}$.) and only 8 or 10 in number. This form-apparently a product of the arid montane district to the west of the Mohave Desert-bears the same relation to var. heterotricha that Professor Greene's L. hispida, ${ }^{37}$ from the "high mountains south of Tehachapi" bears to typical L. glandulosa. L. hispida has also been reported from near Los Angeles by Professor Abrams ${ }^{38}$ but the description in his flora (under Blepharipappus hispidus Greene) is that of L. glandulosa. The original description of $L$. hispida calls for a plant with narrow entire leaves, small heads, inconspicuous rays, and a pappus with the inner hairs interlaced.

Blepharipappus nudatus Greene, Pitt. iii. 168 (1897), is a form from Lower California with entire leaves, short rays, and few or no glands: approached in specimens from Del Mar, San Diego Co., Brandegee.

L. Carnosa (Nutt.) T. \& G., said by Nuttall to have been collected on the beach at San Diego, has not been found south of Monterey Co. by recent collectors. Mr. Parish ${ }^{39}$ thinks that either it has become extinct at San Diego or there was an error in Nuttall's locality. It has a succulent herbage, minute white rays, and 20 or more pappus-bristles, these sparsely plumose with straight hairs.

2. L. elegans (Nutt.) T. \& G., Fl. ii. 394 (1843). Madaroglossa elegans Nutt., Trans. Am. Philos. Soc. ser. 2, 393 (1841). Blepharipappus elegans Greene, Pitt. ii. 246 (1892).

Simple or diffuse, 1.5 to $8 \mathrm{dm}$. high: herbage short-hispid, the stems often brown-dotted; stipitate glands small and scat-

37 Pitt. ii. 20 (1889).

38 Bull. So. Calif. Acad. ii. 14 (1903), and Abrams, Fl. Los Angeles and Vic., 424 (1904).

39 Zoe v. 119 (1901). 
tered: leaves linear, the lower toothed or pinnately parted: rays 10 to 13 , yellow, sometimes tipped or edged with white, 8 to 2 $\mathrm{cm}$. long: pappus white, villous with copious and interlaced hairs, much shorter than the awn-like bristles.

Very common on plains and in the foothills from. Lower California to San Bernardino and Santa Barbara; less plentiful in middle California. A plant gathered near Riverside ( Hall, no. 3981) has one head with deep-yellow ligules and two heads in which the ligules are straw-color with rose-purple tips, recalling the purple-rayed state of $L$. glandulosa.

3. L. hieracioides (DC.) H. \& A., Bot. Beech. 358 (1840). Madaroglossa hieracioides DC., Prodr. v. 694 (1836). Blepharipappus hieracioides Greene, Pitt. ii. 246 (1892).

Coarse erect plant, 3 to $9 \mathrm{dm}$. high : stems mostly simple below and branching above, hispid with hairs arising from dark spots: lower leaves oblong, 4 to $8 \mathrm{~cm}$. long, laciniate-dentate, usually somewhat narrowed at base; upper leaves broadest at the sessile base, the teeth fewer and mostly toward the apex: involucre 7 or $8 \mathrm{~mm}$. high: rays yellow, little exceeding the disk: pappusbristles about 15 , dull white or rusty, pubescent with straight hairs.

From Mendocino Co. to Point Sal, Miss Eastwood, and Santa Barbara, Brandegee.

4. L. graveolens Greene, Bull. Calif. Acad. i. 92 (1885). Blepharipappus graveolens Greene, Pitt. ii. 246 (1892).

Commonly simple below, sparingly branched above, about 3 to $5 \mathrm{dm}$. high: herbage short-hirsute and with numerous black stipitate glands, or succulent and nearly glabrous when growing in moist places: leaves narrowly lanceolate, obtuse, rarely toothed: involucre $9 \mathrm{~mm}$. high : rays lemon-yellow or eream-eolor, 1 to $1.5 \mathrm{~cm}$. long: achenes slenderly clavate: pappus either bright white or sordid, the hairs of the 15 to 20. bristles all straight and erect.

Tehachapi, Kern Co., Jun., 1884 (type), and May 17, 1905, Mrs. Curran; mouth of North Creek, Mt. Pinos, Ventura Co., at 1600 m. alt., Hall, no. 6476; Alealde, Fresno Co., Brandegee; all in the Upper Sonoran Zone. 
5. L. platyglossa (F. \& M.) Gray, Pl. Fendl. 103 (1849). Callichroa platyglossa F. \& M., Ind. Sem. Petr. ii. 31 (1835). Layia platyglossa breviseta Gray, Bot. Calif. i. 370 (1876). Blepharipappus platyglossus Greene, Pitt. ii. 246 (1892). Tidy Tips.

Simple or more commonly branching below, erect or sometimes diffuse, 2 to 6 or $8 \mathrm{dm}$. high: herbage short-hirsute and usually with some small stipitate glands: basal leaves oblong, toothed or pinnatifid, the rameal narrower and either toothed or entire, the uppermost linear and entire: peduncles turbinatethickened beneath the head: involucral bracts linear, with broad tips : rays 5 to 13 , sulphur-yellow, the tips commonly white, 1 to $1.2 \mathrm{~cm}$. long: disk-achenes somewhat flattened, densely clothed with appressed silky hairs: pappus of 15 to 20 upwardly scabrous stout awn-like bristles, nearly as long as the corolla, neither villous nor plumose, rarely wanting.

Common throughout western California; east barely to the edge of the Colorado Desert. Mrs. Brandegee has gathered specimens near San Diego to illustrate variation in coloring: in some the rays vary from lemon-yellow to orange-yellow on a single plant, while others have yellow rays with purple tips. Here also the pappus is occasionally sepaloid, the bristles being broad, thin, and yellowish.

L. Jonesir Gray, with pale-yellow ligules and a pappus of oblong-ovate naked paleae, grows in San Luis Obispo Co., not far from our northern boundary.

\section{ACHYRACHAENA Schaver.}

Soft-pubescent annual with narrow leaves, the lower opposite, and rather large heads terminating the few erect branches. Involucre oblong-campanulate, its bracts lanceolate, each enfolding a ray-achene. Bracts of the receptacle membranous, in a single series between ray and disk. Ray-flowers 5 to 10, little exceeding the disk; their ligules short and broad, palmately 3-cleft. Ray-achenes fertile, linear-clavate, all the ribs or the alternate scabrous. Disk-achenes with a pappus of about 10 silvery scales, the outer as long as the achene, the inner nearly twice as long. 
1. A. mollis Schauer, Del. Sem. Hort. Vratisl. 3 (1837).

Erect, simple or branching, 2 to $4 \mathrm{dm}$. high, pilose-pubescent: leaves linear, remotely toothed or entire, $12 \mathrm{~cm}$. or less long: heads solitary, in flower 15 to $20 \mathrm{~mm}$. high, in fruit expanding and becoming globose, then 3 or $4 \mathrm{~cm}$. broad: rays light yellow, soon changing to reddish-brown: paleae of the achenes expanding or rotately diverging.

In open places toward the coast throughout the Upper Sonoran Zone of western California, but not common in the south : Ramona and Ysidora, San Diego Co.; Pasadena, acc. to McClatchie; Santa Cruz Island, ace. to Greene ${ }^{40}$; common on Santa Catalina Island, acc. to Brandegee ${ }^{41}$; Ojai, Ventura Co.

\section{Tribe 7. HELENIEAE. SNeEzeweed Tribe.}

\section{JAUMEA Pers.}

Perennial glabrous herbs. Leaves linear, entire, opposite, connate in pairs at base. Heads medium-sized, many-flowered, solitary, terminating the branches. Flowers yellow, the rays pistillate, all fertile. Involucre cylindraceous-campanulate, its bracts broad and imbricated, the outermost short. Receptacle naked, eonical. Corolla glabrous. Style-branches of the diskflowers thickened upward and papillose. Achenes linear, striately 10-nerved.

1. J. carnosa (Less.) Gray, Wilkes. Exped. xvii. 360 (1874). Coinogyne carnosa Less., Linnaea vi. 521 (1831).

Stems rather slender, many from the fleshy crown of the taproot, mostly simple, 1 to 2 or $3 \mathrm{dm}$. long, decumbent at base and rooting at the nodes: herbage succulent: leaves semiterete, about 2.5 (1.5 to 5 ) $\mathrm{cm}$. long: involucre $1 \mathrm{~cm}$. high : rays mostly 5 to 10 , not longer than the convex disk: achenes glabrous: pappus none.

Common in saline soil all along the California coast, and to British Columbia.

40 Bull. Calif. Acad. ii. 403 (1887).

41 Zoe i. 139 (1890). 
60. VENEGASIA DC.

Perennial herb with tall leafy stems. Leaves petioled, ovate, cordate or truncate at base, acuminate, crenate-dentate to subentire. Heads large, few, in the upper axils and terminal, shortpedunculate, heterogamous. Involucre of 2 or 3 series of broadly oval mostly membranaceous erect bracts, the innermost and the herbaceous outermost narrower than the intermediate ones. Receptacle flat. Corolla-tube densely glandular-bearded at base. Rays numerous, showy, yellow. Achenes many-nerved. Pappus none.-A single species restricted in distribution to the Coastal Subarea of Southern California.

1. V. carpesioides DC., Prodr. vi. 43 (1837).

Erect, sparingly branched, commonly 1 to $2.5 \mathrm{~m}$. high: herbage glabrous, or minutely pubescent above: leaves thin, 5 to 15 $\mathrm{cm}$. long, 3 to $12 \mathrm{~cm}$. broad at base; petioles 2 to $5 \mathrm{~cm}$. long: rays 13 to 20 , about $2.5 \mathrm{~cm}$. long, normally entire and acute, often toothed or irregularly lacerate at tip: achenes about 12-nerved, papillose-roughened.

In moist or shaded places of the Coastal Subarea, especially in ravines of the hill district, from Santa Barbara south nearly to San Diego Co.: common along the southern foothills of the Santa Inez Mts., Santa Barbara Co.; also plentiful in the shade of Live Oaks at 600 to $1000 \mathrm{~m}$. alt. in the west fork of Matilija Cañon, Ventura Co.; Casitas Pass, Ventura Co.; Santa Rosa Island, acc. to Brandegee ${ }^{42}$; Santa Cruz Isl.; Santa Monica and Laurel cañons, near Los Angeles; Sherman and Santa Ana Mts., acc. to Abrams; Temecula, Riverside Co.; and to be expected further southward.-General aspect of Helianthus, for which it is sometimes mistaken.

\section{PSILOSTROPHE DC.}

Xerophytic herbs or low shrubs with narrow alternate leaves. Heads rather small to medium-sized, solitary or cymose. Rayflowers 3 to 8 , pistillate, the yellow ligule persistent and becoming papery. Disk-flowers 5 to 12 , perfect and fertile; the corollas 
elongated-cylindraceous, with very short proper tube and short externally glandular-bearded teeth. Style-branches truncatecapitate. Achenes narrow, terete, obscurely nerved or angled. Pappus of 4 to 6 hyaline paleae.

De Candolle's Psilostrophe dates from 1838, whereas Nuttall's Riddellia, a better-known name for the same genus, dates from 1841. By the rule of priority, Psilostrophe is therefore the name to be retained.

1. P. Cooperi (Gray) Greene, Pitt. ii. 176 (1891) ; A. Nelson, Proc. Biol. Soc. Wash. xvi. 20 (1903). Riddellia Cooperi Gray, Proc. Am. Acad. vii. 358 (1868).

Shrubby at base, the rounded clumps about $5 \mathrm{dm}$. high : herbage white with a densely pannose tomentum: leaves linear or narrowly spatulate and obtuse, entire, 1 to $5 \mathrm{~cm}$. long, green and glabrate in age: heads scattered, on evident peduncles: involucre 5 to $7 \mathrm{~mm}$. high; bracts 15 to 30 , the inner ones much softer than the rigid and oblong outer ones : rays 4 to 8 , broadly oval, 1 or 2 cm. long, shallowly 3-lobed at the broad apex: pappus-paleae oblong or lanceolate, entire to erose-laciniate, shorter than the achene.

Lower Sonoran Zone: Chuckawalla Bench, Colorado Desert, in Riverside Co., Schellenger, no. 24, and Hall, no. 5890; Providence Mts., Mohave Desert, Brandegee; Arizona ; Nevada; Lower California.

\section{BAILEYA Harv. \& Gray.}

Densely white-woolly erect annuals or perennials of the Desert Area. Lower leaves pinnatifid, the upper entire, all alternate. Heads solitary, on conspicuous peduncles. Involucre of numerous distinct densely floceose bracts. Ray-flowers pistillate; ligules yellow and showy when young, becoming papery and reflexed in age. Disk-flowers numerous, fertile, the corolla gradually expanding above the short proper tube, the teeth bearded. Stylebranches short, obtuse. Achenes oblong or clavate, truncate at the obscurely toothed apex, conspicuously pluristriate. Pappus none. 
1. B. pauciradiata Harv. \& Gray, Pl. Fendl. 105 (1849).

Freely branching, 1 to $5 \mathrm{dm}$. high from a perennial root (but flowering the first year), leafy, clothed throughout with a white and floccose woolly tomentum: lower leaves oblong or spatulate, few-toothed or -lobed, the longest over $7 \mathrm{~cm}$. long; upper leaves shorter, oblong or lanceolate to linear, closely sessile: involucre $5 \mathrm{~mm}$. high: rays roundish-oval, 5 to $10 \mathrm{~mm}$. long, the nerves conspicuous: achenes muriculate on the nerves, obscurely resinous-atomiferous.

Rather common in sandy soil of the Lower Sonoran Zone from Palm Springs, Colorado Desert, and Ash Hill, Mohave Desert, east into Arizona.

2. B. multiradiata pleniradiata (Harv. \& Gray) Coville, Contr. U. S. Nat. Herb. iv. 133 (1893). B. pleniradiata Harv. \& Gray, Pl. Fendl. 105 (1849). B. multiradiata Gray, Syn. Fl. i. pt. 2, 318 (1884) ; not B. multiradiata Harv. \& Gray, in Emory Rept. 144 (1848).

Annual or perennial, usually taller than B. pauciradiata; herbage similarly white-woolly but the pubescence more appressed: branches chiefly basal, ascending or erect: lower leaves variously cleft into short obtuse lobes, narrowed to a wingmargined petiole; upper leaves small, mainly entire and sessile: heads on slender often much elongated peduncles : involucre hemispheric; its bracts narrowly oblong, acute : rays 8 to $12 \mathrm{~mm}$. long, oblong or at length broader, narrowed below, 3-toothed at the truncate apex: disk-flowers numerous: achenes as in $B$. pauciradiata.

In loose or sandy soil of the Lower Sonoran Zone from Rabbit Springs and Ludlow, on the Mohave Desert, and Paloverde, Colorado Desert, to New Mexico and Lower California. Also in southwestern Inyo Co. The original B. multiradiata is the form with long naked peduncles and large heads, not known from California (=var. nudicaulis, of Syn. Fl.)

\section{PERITYLE Benth.}

Annual or biennial herbs. Herbage glabrous or viscid-pubescent, never white-woolly. Leaves petiolate, the upper alternate, the lower often opposite. Heads numerous, on evident peduncles, 
many-flowered. Involucral bracts in a single series, the margins overlapping, faintly keeled externally, shallowly grooved on the inner surface, the groove being occupied by the outer edge of the ray-achene. Disk-flowers numerous, yellow, 4-toothed. Rays short, white or yellow. Achenes flat with ciliate or eartilaginous margins. Pappus a squamellate or cupulate erown and often a slender awn from one or both of the angles.

1. P. Emoryi Torr., Emory's Rept. N. Mex. 142 (1848) ; Rose, Bot. Gaz. xv. 116 (1890). P. nuda Torr., Pacif. R. Rept. iv. 100 (1857). P. Californica Gray, Syn. Fl. i. pt. 2, 321 (1884), in part; not P. Californica Benth. P. Greenei Rose, Bot. Gaz. xv. 117 (1890).

Three to $6 \mathrm{dm}$. high, the striate stems freely branching and widely spreading from an annual or more enduring root: herbage viscid and glandular-pubescent throughout and also somewhat short-hirsute, or glabrate below, ill-seented: leaves roundish or cordate in outline, incisely 5 to 9-lobed or -cleft, the divisions acutely few-toothed; lower leaves $1.2 \mathrm{~cm}$. long on petioles of equal length; upper smaller, often nearly sessile: peduncles 1 to $4 \mathrm{~cm}$. long: heads $7 \mathrm{~mm}$. high: outer involucral bracts oblong, acute, ciliate; inner bracts narrower, searious-margined: rays about 12 , 2 or $3 \mathrm{~mm}$. long; all the corollas glandular-pubescent: stylebranches with short minutely hirsute appendages: achenes flat, oblong to subclavate, black, smooth and shining or rarely puberulent on the sides, hispid-ciliate on the margins : pappus an inconspicuous erose or lacerate crown and a single slender awn about as long as the achene, or the awn usually wanting.

Lower and Upper Sonoran zones : near Santa Monica, Hasse; Catalina Island, Davidson; San Clemente Island, Nevin \& Lyon, ace. to Rose; San Diego, Hall; throughout the Colorado Desert, various collectors; Newberry, in the southern part of the Mohave Desert; Panamint Mts. (in the epappose form); Arizona and Mexico.

Often forming dense clumps 5 to $10 \mathrm{dm}$. in diameter, covered with a profusion of flower-heads, in which the yellow disks are sometimes as conspicuous as the white rays. Some specimens have been referred to $P$. microglossa $(=P$. acmella of Bot. 
Calif.), but that is a species of Mexico, far beyond our limits. The form in which the pappus-awn is wanting is the var. nuda of Gray (=P. nuda Torr.). Both forms occur throughout the range of the species. P. Greenei Rose, of Santa Cruz and Cedros islands, etc., is an indistinguishable form. Acc. to Greene it is strongly aromatic. Dr. Rose has also described (Bot. Gaz. xv. 117) as P. Emoryi var. Orcuttii "a slender form with small leaves, achenes with small crown or none, and often with faces quite pubescent" from material collected at Cantillas, Lower California.

P. Plumigera Gray, Pl. Fendl. 77 (1849). Leaves small: heads narrow, barely $6 \mathrm{~mm}$. high: awn solitary, longer than the achene.-Known only from Coulter's "Californian collection," but it is probable (ace. to Gray) that the specimens were gathered in Arizona. Perhaps only a form of P. Californica.

P. Le:toglossa Gray, 1. c. Leaves 1.2 to $2 \mathrm{~cm}$. long: heads 1 $\mathrm{cm}$. high, with rays $8 \mathrm{~mm}$. long: disk-corollas with very slender tube and long and narrow cylindrical throat: awn solitary, longer than the achene, exceeded by the disk-corolla.-Likewise reported from California, Coulter, but probably Arizonan, or more likely only Mexican. Dr. Rose ${ }^{43}$ reports that there is a specimen in the U. S. National Herbarium from Guaymas, Mexico, collected by Dr. Palmer in 1869.

P. Rotundifolia Brandegee, Zoe iv. 210 (1893). Amauria rotundifolia Benth., Bot. Sulph. 31 (1844). Perityle Fitchii Torr., Pacif. R. Report. iv. pt. 5, 100 (1857); Brandegee, Proc. Calif. Acad. ser. 2, ii. 177 (1889); Rose, Bot. Gaz. xv. 113 (1890). Laphamia peninsularis Greene, Bull. Calif. Acad. i. \& (1884). Best distinguished by its 4 -angled achenes; the faces smooth, the angles slightly hirsute with straight appressed hairs.- "California, Rev. A. Fitch," according to the label. Since it has been frequently collected in Lower California but not again reported from upper California, it seems very unlikely that it occurs within our limits.

43 Bot. Gaz. xv. 118 (1890). 


\section{LASTHENIA Cass.}

Glabrous slightly succulent annuals. Leaves opposite, mostly narrow and entire, sessile. Heads on slender peduncles terminating the branches. Involucral bracts 5 to 15 , more or less united into a hemispheric or campanulate toothed cup. Receptacle conical, covered with projecting points which bear the linear or linearoblong flattened achenes. Flowers yellow. Pappus, in ours, none.

1. L. glabrata Coulteri Gray, Syn. Fl. i. pt. 2, 324 (1884). L. Coulteri Greene, Bull. Calif. Acad. i. 192 (1885).

Usually branching, 1.5 to $3 \mathrm{dm}$. high: leaves linear and entire or sometimes the upper pair broadly lanceolate and toothed, conspicuously connate and sheath-like at base: peduncles erect, often elongated : involucre broadly hemispheric, 5 to $7 \mathrm{~mm}$. high : ligules about $8 \mathrm{~mm}$. long: achenes narrowly obovate, mostly with obtuse edges, the surface sprinkled with yellow rough gland-like points.

Common along borders of salt-marshes near the coast and on inland alkali flats from San Diego to Santa Barbara and the San Joaquin Valley.

There has been an attempt to specifically separate $L$. Coulteri, the southern form, from $L$. glabrata, of middle and northern California, on the basis of achenial characters, but these characters are inconstant. The achenes of the typical form are probably never "perfectly smooth" but, as viewed through the microscope, are always more or less roughened with minute papillae resembling, except for size, the more conspicuous ones of the variety. The papillae of the variety are, moreover, quite variable. They are commonly globular or obtuse-cylindrical in shape, but in specimens from the San Joaquin Valley (Davy, no. $2430)$ they are slender and acute with incurved tips. The surface of the achenes from a single head varies in color from silvery gray and shining to dull brown and lustreless, this range being shown in specimens from near San Diego (Hall, no. 3956). The achenes are usually more obtusely angled in the variety than in the species but sometimes the angles are decidedly acute, as, for example, in specimens collected in Ventura Co., Apr. 7, 1902, by Davy. Since these achenial characters are thus shown to be inconstant and since there is not the least difference between the 
two forms as regards habit, foliage, or flower, there is no apparent reason for assigning specific rank to $L$. Coulteri. It may be retained as a variety of $L$. glabrata, however, because of the more conspicuous papillae of its achenes.

\section{BAERIA F. \& M. Gold Fields.}

Ours low and mostly slender annuals. Herbage commonly pubescent and often glutinous but never hoary. Leaves opposite, linear, entire or laciniate-pinnatifid. Flowers yellow, the heads on slender peduncles. Involucre campanulate or hemispheric, its bracts as many as the rays, ovate or oblong and becoming more or less carinate below the middle in most species. Receptacle from hemispheric to subulate, usually conical. Ray-flowers mostly 5 to 18 ( 1 to 4 in $B$. microglossa), pistillate, showy for the size of the heads, or the ligules sometimes very short. Diskflowers hermaphrodite, their style-branches obtuse and either with or without a minute appendage. Achenes linear, but somewhat broadened upward. Pappus of paleae, or awns, or both, or none.

All of our species of Baeria, save only the first, which belongs to the monotypic subgenus Burrielia, are very closely related. This relationship is so close that even Doctor Gray's division into three sections, representing the three genera, Baeria, Dichaeta, Ptilomeris, of earlier botanists, is of doubtful value. ${ }^{44}$ These genera were based on characters of the pappus, receptacle, and leaves. Pappus characters are entirely unreliable (as I shall demonstrate under $B$. chrysostoma, and $B$. aristata), several species of Eubaeria and Ptilomeris exhibiting at times the pappus of Dichaeta, while epappose forms may be expected in any species. The receptacle is described as muricate-roughened in Eubaeria and Dichaeta, scrobiculate in Ptilomeris. But the receptacle in every case is covered wtih papillae, each papilla being more or less concave or cup-shaped at summit where it fits around the eallous base of its achene. Now, if the papillae are elongated and distinct the receptacle will appear muricate, as is always the case, so far as I am aware, in Eubaeria and Dichaeta; but, if the papillae are short, thick, and close together, they present a smooth

\footnotetext{
44 Of our species, no. 2, belongs to Dr. Gray's § Eubaeria; no. 3 to §
} Dichaeta; no. 4 to § Ptilomeris. 
surface marked only by the depressions which once surrounded the bases of the achenes, and such a receptacle will appear scrobiculate, as is often, but not always, the ease in Ptilomeris. In B. aristata, of the Ptilomeris section, the receptacle is often as plainly muricate as in species of Eubaeria; or a portion of the receptacle may be muricate while the remainder is merely scrobiculate, as a result of fusion of the papillae. The receptacle is commonly glabrous in Eubaeria and Dichaeta, glabrous to densely villous in Ptilomeris. It is thus seen that neither pappus nor receptacle furnishes characters upon which to found species, much less sections or genera, and leaf characters are likewise elusive, as may be inferred from the specific descriptions beyond.

Involucre of only 3 or 4 bracts: ligules obsolete or wanting: pappus of attenuate paleae: leaves entire

1. B. microglossa.

Involucre of more numerous bracts.

Leaves all linear and entire.

2. B. chrysostoma.

Leaves toothed, cleft, or parted, or some entire.

Leaves broadly linear to oblong: plants robust: pappus either of two sorts or none

3. B. uliginosa.

Leaves or their divisions filiform or linear

4. B. aristata.

1. B. microglossa (DC.) Greene, Fl. Fr. 438 (1897). Burrielia microglossa DC., Prodr. v. 664 (1836).

Stems very slender, the plant $5 \mathrm{~cm}$. to 1 or $2 \mathrm{dm}$. high: herbage more or less hirsute: leaves linear, 1 to $3 \mathrm{~mm}$. wide or the upper sometimes more dilated: involucre cylindric, 5 to $8 \mathrm{~mm}$. high; bracts only 3 or 4, oblong: receptacle subulate: pistillate flowers 1 to 3 , their ligules shorter than the styles or wanting: disk-flowers not over 15 : achenes fusiform-linear, flattish, sparsely short-pubescent: pappus-paleae 2 to 4 , attenuate-subulate.

Andreas Cañon, near Palm Springs, Colorado Desert, Apr., 1882, Parish, no. 747; San Luis Obispo Co. to middle California, on low ground.

2. R. chrysostoma F. \& M., Ind. Sem. Hort. Petrop. ii. 29 (1835). Gold Fields.

Plant low and with unbranched stems when growing in poor or dry soil; becoming robust, profusely branched, and 10 to 25 $\mathrm{cm}$. high under favorable conditions: herbage strigulose to hirsute: leaves narrowly linear, $3 \mathrm{~mm}$. or less wide, entire: in- 
volucre broad, 3 to $6 \mathrm{~mm}$. high; bracts 10 to 15 (or 18) or in depauperate plants 5 to 10 : ray-flowers as many as the bracts; ligules 3 to $8 \mathrm{~mm}$. long: style-tips capitate and seldom, if ever, with a minute apiculation: achenes in the typical form linearclavate, slightly rounded at summit, either perfectly smooth and shining or with minute rounded papillae: pappus in the typical form none.

Southern Oregon to Lower California and the borders of Arizona: in its numerous varieties and forms very abundant in early spring on plains and over the lower foothills, often covering the slopes for miles with its golden-yellow bloom; rare on the deserts and not found in the mountains above the Upper Sonoran Zone. The typical form, distinguished from the following varieties only by the achenes, has been reported as rather common around Los Angeles and may occur throughout western California. I have not seen it south of Antelope Valley. A specimen determined by Meyer, now in the Brandegee Herbarium, has clavate achenes, rounded at summit, not pubescent but minutely papillose; the herbage is succulent and the heads large with broad involucre, as in the sea-coast form.

Var. gracilis (DC.) Hall, comb. nov. Burrielia gracilis DC., Prodr. v. 664 (1836). Baeria gracilis Gray, Proc. Am. Acad. ix. 196 (1874). Achenes linear, truncate, more or less strigosepubescent: pappus usually present.-The typical form of this variety has a pappus of 3 or 4 awns from small lanceolate paleae, about equalling the disk-corollas. Very abundant in Southern California. The following forms, most of them treated as varieties of $B$. gracilis or as distinct species in Gray's Synoptical Flora (where full synonymy), are here referred to the var. gracilis.

Var. gracilis f. nuda Hall, form. nov. Pappus none.-A form very close to typical $B$. chrysostoma but the achenes are narrower, not at all rounded at the summit, and more conspicuously pubescent. However, perfectly glabrous achenes are sometimes very narrow and truncate, and all degrees of pubescence occur, so that these characters cannot be used for specific diagnoses.-San Franeisquito Cañon, Los Angeles Co., Hall, no. 3100, and elsewhere with the typical form of var. gracilis. 
Var. gracilis f. aristosa (Gray) Hall, comb. nov. B. gracilis aristosa Gray, Proc. Am. Acad. xix. 21 (1883). B. aristosa Howell, Fl. N. W. Am. 354 (1900). Disk-pappus of 3 or 4 awns very gradually and slightly widened downward.

Var. gracilis f. tenerrima (DC.) Hall, comb. nov. Burrielia tenerrima DC., Prodr. v. 664 (1836) ? B. gracilis tenerrima Gray, Syn. Fl. i. pt. 2, 326 (1884). Disk-pappus of f. aristosa but awns often fewer: stems low and slender, often simple : rays and bracts only 5 or 6 each.-A starved form of sterile soil. Mr. Parish has collected in the San Bernardino Mts. some specimens (no. 235 as represented at Univ. Calif. Herb.) of this form in which the receptacle is paleaceous, each achene being subtended by a cuneate palea of its own length.

Var. gracilis f. paleacea (Gray) Hall, comb. nov. B. gracilis raleacea Gray, Proc. Am. Acad. xix. 21 (1883). B. Clevelandi Gray, 1. c. 22. Disk-pappus of 2 to 4 ovate or deltoid paleae more or less abruptly contracted to a slender awn.-B. Clevelandi was described as glabrous except for some fine deciduous woolliness, the style-tips with a conical or subulate appendage, and the pappus of only 2 paleae. Mrs. Brandegee, after having examined the type, says that she is unable to detect any difference between the pubescence or style-tips of $B$. Clevelandi and of $B$. gracilis, and that in the type of the former the pappus-paleae are sometimes 3 in number. Further evidence against $B$. Clevelandi as a species is the following: Specimens from Ocean-Beach, near San Diego, Apr. 21, 1894, Brandegee, have all the characters of $B$. $c$. gracilis except that the pappus-paleae are only 2 or 3 in number and with the shape assigned to those of $B$. Clevelandi; specimens from Rialto, San Bernardino Co., Hall, no. 2941, duplicate the pappus characters of $B$. Clevelandi in some flowers, other flowers from the same plant have 4 awned paleae, and still others have 2 paleae and 2 intermediate squamellae, etc. The style-tips and pubescence of my. no. 2941 are as in the common form of $B$. c. gracilis.

Var. gracilis f. Clementina (Gray) Hall, comb. nov. $B$. Palmeri Clementina Gray, Syn. Fl. i. pt. 2, 452 (1886). Paleae of both ray and disk-flowers mostly 5, ovate, firm, attenuate into a stout awn, sparingly erose-laciniate or only denticulate: plants 
robust.-Known only from the Californian islands, but almost duplicated, so far as pappus is concerned, by small specimens from the San Joaquin Valley (Davy, no. 1739a), in which the pappus-paleae are entire to erose, or even dentate with long sharp teeth.

Var. gracilis f. crassa Hall, form. nov. Disk-pappus of 4 entire lanceolate paleae each tapering to a slender awn: stems low, stout, branched: herbage somewhat succulent: leaves narrowly oblong, obtuse, 1.5 to $3 \mathrm{~mm}$. broad-A seashore form: Ocean Beach, near San Diego, May, 1906, Mrs. Brandegee.

Var. gracilis f. curta (Gray) Hall, comb. nov. B. curta Gray, Proc. Am. Acad. xix. 21 (1883). Pappus of ovate or oblong paleae, most or all of them obtuse or truncate and destitute of awn.-The original specimens were described as having "pappus of ovate or oblong pointless paleae, not exceeding the breadth of the achene, usually 4 or 5 , or in ray-flowers reduced to a single one, in some plants all obsolete." They were from near San Bernardino, Wright, Lemmon, and the form has recently been found near Riverside by Geo. R. Hall, no. 1669. I have examined some of Mr. Lemmon's plants gathered with the types (no. 135 ) and find the paleae to be 2 to 4 in number or more often entirely wanting. Specimens collected by myself (no. 2971) on Box Springs Mt., not far from San Bernardino, exhibit the following variations in pappus, all the achenes being taken from a single head: achene (a), one lanceolate palea tapering into a siender awn (as in paleae of typical B. $c$. gracilis) the whole equalling the achene, no other pappus; achene (b), 2 erose paleae equalling the breadth of the achene; achene (c), 1 erose palea equalling the breadth of the achene and 3 minute scales; achene (d), four minute scales; achene (e), one minute scale; achene (f), pappus none. Other combinations could be cited and most of the specimens under this number have achenes destitute of pappus. This demonstrates the extreme variability of pappus characters in this genus even on individual plants, and leads one to the conclusion that species founded on such characters alone eannot stand.

3. B. uliginosa (Nutt.) Gray, Proc. Am. Acad. ix. 197 (1874). Dichaeta uliginosa Nutt., Trans. Am. Philos. Soc. ser. 2, vii. 383 (1841). 
One to $3 \mathrm{dm}$. high, at length loosely branched and diffuse: herbage somewhat succulent, villous-tomentose when young, commonly glabrate: leaves narrowly oblong to broadly ligulate, laciniate-pinnatifid (especially above the middle) or the upper entire; the larger sometimes 5 to $10 \mathrm{~cm}$. long and with the conspicuously nerved undivided portion $1 \mathrm{~cm}$. broad: involucral bracts and oblong exserted rays 10 to 13 : pappus (rarely wanting) of 2 to 4 awns and about 6 truncate-fimbriate intervening paleae.

An inhabitant of low wet places : Santa Barbara, acc. to Gray; Tulare, Davy; north to San Francisco Bay.

4. B. aristata (Nutt.) Hall, comb. nov. Ptilomeris aristata Nutt., Trans. Am. Philos. Soe. ser. 2, vii. 382 (1841). P. coronaria Nutt., l. c. Baeria coronaria Gray, Proc. Am. Acad. xix. 23 (1883).

Stem simple to diffusely much branched, 5 to $30 \mathrm{~cm}$. high: herbage minutely glandular-pubescent throughout: leaves mostly pinnately parted into long linear-filiform divisions : involucre 4 or $5 \mathrm{~mm}$. high; bracts deciduous with ray-achenes; midnerve prominent: ray-flowers usually about 12 ( 8 to 15 ); ligules 4 to $10 \mathrm{~mm}$. long: pappus of 8 to 12 lanceolate or oblong paleae in the typical form, some or all of them tapering into awns about equalling the corolla.

Very eommon at San Diego (Purpus, Univ. Calif. no. 30414; etc.), thence to Riverside (and Port Ballona, Los Angeles Co., ace. to Abrams). First described as Ptilomeris aristata Nutt., from specimens in which all of the paleae were awned in diskflowers; two of them awned, the remainder muticous, in rayflowers, and the receptacle naked. In $P$. coronaria Nutt. none of the paleae in the ray-flowers are awned and the receptacle is densely villous. That these characters are much too variable, even in individual plants, to be of any value, is very evident from the abundant material now at hand.

f. mutica (Nutt.) Hall, comb. nov. Ptilomeris mutica Nutt., Trans. Am. Philos. Soc. ser. 2, vii. 382 (1841). Baeria mutica Gray, Proc. Am. Acad. xix. 23 (1883). Pappus of oblong paleae, the obtuse or truncate summit erose.-Likewise common at San Diego (Setchell, Univ. Calif. no. 53902; etc.), thence to 
San Jacinto, Beaumont, and Redondo. Specimens gathered by myself near Riverside, under numbers 3714 and 3833, belong partly to this form, partly to typical $B$. aristata, while some exhibit the characters of both. The paleae of disk-flowers are sometimes all truncate and awnless, or from 1 to 4 of them may be awned, all combinations occurring in a single head.

f. anthemoides (Nutt.) Hall, comb. nov. Ptilomeris anthemoides Nutt., Trans. Am. Philos. Soc. ser. 2, vii. 382 (1841). Baeria anthemoides Gray, Syn. Fl. i. pt. 2, 328 (1884). Pappus none: receptacle usually scrobiculate.-Known only from southwestern San Diego Co. (Hall. no. 3950, ete.)

Var. affinis (Nutt.) Hall, comb. nov. Ptilomeris affinis Nutt., Pl. Gamb. 173 (1848). Baeria affinis Gray, Proc. Am. Acad. xix. 23 (1874). Stems slender: involucre 3 or $4 \mathrm{~mm}$. high: rayflowers 6 to 8 ; ligules $4 \mathrm{~mm}$. or less long: pappus, in the typical form, of 6 to 10 oblong or lanceolate paleae as long as the corollatube, the margins erose or laciniate, some or all of them continued into awns about equalling the corolla, or in the ray all blunt and awnless: herbage (always?) sweet-scented.-This form has been collected near Los Angeles and at North Pomona, Claremont, Cajon Pass, and San Bernardino. It differs from typical $B$. aristata only in being generally smaller and more slender, and in having smaller heads with less numerous rays. It has a pappus form (f. truncata) corresponding to f. mutica of $B$. anthemoides.

Var. affinis f. truncata Hall, nom. nov. Ptilomeris tenella Nutt., Pl. Gamb. 173 (1848). Baeria tenella Gray, Proc. Am. Acad. xix. 23 (1883). Not Dichaeta tenella Nutt., Trans. Am. Philos. Soc. ser. 2, vii. 383 (1841), which is Baeria tenella Greene, Fl. Fr. 439 (1897) and Jepson, Fl. W. Mid. Calif. 520 (1901). Pappus of 6 to 10 oblong or cuneate paleae mostly shorter than the corolla-tube, the truncate summit erose or denticulate.Piru, Ventura Co., Hall, no. 3122 ; North Pomona, Braunton, no. 254, in part; Claremont, Chandler; etc. Often found with the typical form of var. affinis, from which it differs only in the pappus, and the two forms are not infrequently mounted in herbaria under a single label. Field observations on the odor of the herbage are desirable. 
Var. Parishii (Wats.) Hall, comb. nov. B. Parishii Wats., Proc. Am. Acad. xxiv. 83 (1889). Plant very slender, seldom over $1.5 \mathrm{dm}$. high : stem simple to much branched above: herbage pubescent with loose hairs: leaves narrowly linear, acute or obtuse, mostly pinnately cleft into one to several pairs of slender lobes, rarely all entire: involucre only 2 to $4 \mathrm{~mm}$. high; bracts 8 to 12 , scarcely enfolding the ray-achenes and the midvein not prominent: ray-flowers 8 to 12 ; ligules about $3 \mathrm{~mm}$. long: styletips truncate-apiculate: achenes linear, with truncate summit, sparsely and minutely pubescent: pappus none in the typical form.-Known only from the type locality; namely, on clay hillsides at about $450 \mathrm{~m}$. alt. in Waterman Cañon, near San Bernardino: May 29, 1888, Parish, no. 2041 (duplicate type), in part; May 8, 1895, Parish, no. 3642, in part.

Var. Parishii f. varia Hall, form. nov. Pappus of 6 to 10 quadrate or ovate paleae with erose summits, some of them provided with awns as long as the corolla.-Claremont, Feb. 10, 1897, Chandler. Corresponds to the typical form of $B$. aristata and of $B$. aristata affinis, so far as pappus is concerned.

Var. Parishii f. quadrata Hall, form. nov. Pappus of 6 to 10 quadrate paleae only half the length of the corolla-tube, their summits erose-truncate.-At the type locality of var. Parishii, F'arish, nos. 2041, in part, and 3642, in part, the remaining plants gathered under these numbers differing only in the eppapose achenes. Bears the same relation to $\mathrm{f}$. varia that $B$. aristata $\mathrm{f}$. mutica does to typical $B$. aristata, and similarly corresponds to f. truncata of var. affinis.

\section{MONOLOPIA DC.}

White-woolly annuals with mostly alternate sessile leaves and long-peduncled heads of golden-yellow flowers. Involucre hemispheric, its bracts either distinct to near the base or united into a cup with broad or triangular teeth. Receptacle globular or conical in our species, naked. Ray-corollas with ample 3 or 4toothed or -lobed ligule and bearing at the orifice on the opposite side of the style a roundish denticulate appendage; lobes of diskcorollas somewhat hairy. Achenes obovoid, angular, black. Pappus none. 
1. M. major DC., Prodr. vi. 74 (1837) ; Hook., Ic. Pl. t. 344 (1841), and Bot. Mag. t. 3839 (1840).

Stoutish, simple or branching, 1.5 to $5 \mathrm{dm}$. high: tomentum floceose and tardily deciduous: leaves mostly oblong-lanceolate, low-denticulate or commonly entire, $8 \mathrm{~cm}$. or less long: involucre mostly 6 to $12 \mathrm{~mm}$. high; bracts united into a broadly campanulate cup with triangular teeth: rays .8 to 1.5 or $2 \mathrm{~cm}$. long, the oblong or roundish denticulate appendage less than $1 \mathrm{~mm}$. in diameter.

Common in the central part of the state and, ace. to the Botany of California, extending southward to San Diego.

Var. lanceolata (Nutt.) Gray, Bot. Calif. i. 384 (1876). M. lanceolata Nutt., Journ. Phila. Acad. i. 175 (1847). Bracts of the involucre distinct to near the base; otherwise as in the species. - Grassy slopes, especially on heavy soils; Upper Sonoran Zone; apparently rather rare: Highland Park, Los Angeles, Greata; Cahuenga Pass, Brewer, no. 185; San Rafael Mts., Santa Barbara Co., Hall, no. 7805; Antelope Valley, Dr. Vogt, no. 51, and Davy, no. 2166; head of San Joaquin Valley, Davy, nos. 1704, 1893b, 1724, 1990. Mr. Davy's specimens nos. 1704 and 1724 from near Bakersfield, specimens gathered in Tulare Co. by Mr. G. C. Roeding, and also Brewer's no. 185 from Cahuenga, approach in the size of their involucres and achenes very closely to $M$. gracilens Gray, which should be considered only a smallflowered variety of $M$. major.

\section{SYNTRICHOPAPPUS Gray.}

Low and commonly diffuse white-woolly annuals principally of the Desert Area. Leaves narrow, entire, or lobed at the apex, mostly alternate. Heads small, short-peduncled, with yellow or purplish ray-flowers and yellow disk-flowers. Involucre narrow, of 5 to 8 narrow bracts partly enfolding the ray-achenes. Receptacle small, flat. Style-branches flattened, acute. Achenes linear-turbinate, pubescent. Pappus of numerous bristles united at base or none.

Rays yellow: pappus of numerous barbellate awns 1. S. Fremonti. Rays rose-purple, edged or marked with white: pappus none

2. S. Lemmoni. 
1. S. Fremonti Gray, Pacif. R. Rept. iv. 106, t. 15 (1857).

Plant low and spreading, much branched from the base: leaves broadly linear or spatulate, sometimes shallowly 3-lobed near the apex, 5 to $15 \mathrm{~mm}$. long: heads short-pedunculate: involucre 5 or $6 \mathrm{~mm}$. high, the bracts scarious-margined: rays golden-yellow, 3 to $6 \mathrm{~mm}$. long: pappus bright white, the numerous barbellate bristles often paleaceously united at base, deciduous.

Abundant from Cajon Pass to the Mohave River, Parish, no. 1267, and Hall, no. 6179; Randsburg, Mohave Desert, C. M. Drake, no. 8; Cameron, Tehachapi Pass, Brandegee; Inyo Co., Purpus, Brandegee, Coville \& Funston; Soda Lake, Cooper, ace. to Gray; east to Utah and Arizona.

2. S. Lemmoni Gray, Proc. Am. Acad. xix. $20^{\prime}$ (1883). Actinolepis Lemmoni Gray, Proc. Am. Acad. xvi. 101 (1880). Microbahia Lemmoni Ckll., Muhlenbergia iii. 9 (1907).

Stem very slender, often erect, only a few $\mathrm{cm}$. high: herbage glabrate in age: leaves linear or slightly enlarged above, entire: involucre 4 or $5 \mathrm{~mm}$. high, its 6 to 8 bracts narrowly oblong and scarious-margined: rays 7 or 8 , fading from rose to flesh-color, commonly almost white on the upper surface, deep rose and with dark-red veins beneath, the margins white.

Manzana, Antelope Valley, Davidson; Cajon Pass., Parish, no. 1250, Hall \& Chandler, no. 6756; San Bernardino Plains, Mar., 1880, Lemmon.

\section{HYMENOPAPPUS L'Her.}

Herbs with alternate or mostly basal pinnatifid leaves. Heads medium-sized, discoid in most species, borne in an open .panicle or solitary and terminal on the elongated branchlets. Involucral bracts 6 to 12 , in 1 or 2 series, broad, the margins searious and often colored. Corollas with narrow tube, abruptly dilated throat, and spreading or recurved lobes. Achenes obpyramidal, 4 to 5-angled. Pappus of 10 to 20 thin obtuse or awned paleae, sometimes reduced or wanting.

Pappus-paleae not awn-tipped: flowers yellow.

Involucral bracts very unequal 1. H. lugens.

Involucral bracts nearly equal 2. H. filifolius. Pappus-paleae awn-tipped: flowers white or purplish 3. H. Wrightii. 


\section{H. lugens Greene, Pitt. iv. 43 (1899).}

Stems erect, from a perennial multicipital caudex, 3 to $5 \mathrm{dm}$. high: herbage loosely tomentose, the stems glabrate: leaves clustered near the base, about $8 \mathrm{~cm}$. long including the petiole, twice or thrice pinnately parted into linear acute lobes: heads scattered, on slender peduncles: involucral bracts broadly oblong or obovate, obtuse, very unequal, the short outer ones with broad reddish-brown margins, the inner somewhat scarious or greenish: rays none: disk-flowers yellow; throat eylindric, narrowed to the nearly equal tube: anthers exserted : style-tips conic: villous hairs of the achene somewhat shorter than the strongly 1-nerved obtuse paleae, which either equal or are somewhat shorter than the proper tube of the corolla.

Mountains and foothills bordering the deserts: Transition Zone at Bear Valley, San Bernardino Mts., Parish, no. 3717, Hall, nos. 1339, 7558, and Abrams, no. 2899; Lower Sonoran Zone at Coyote Cañon, Riverside Co., Hall, no. 1178.1; Warner's Ranch, San Diego Co., ace. to Parish; Cuyamaca Mts., Jul. 16, 1906, Mrs. Brandegee; Tantillas Mts., Lower California, Palmer, no. 183; San Pedro Martir, Lower California, Brandegee. Professor Greene includes Inyo Co. in the range of $H$. lugens, but he had only specimens collected by Mr. Parish and the latter informs me that he has not botanized in Inyo Co. An excellent species, well marked, in its group, by the very unequal bracts of the involucre.

2. H. filifolius Hook., Fl. Bor. Am. i. 317 (1834).

Stems several and erect from the perennial caudex, 3 to $6 \mathrm{dm}$. high, somewhat leafy: herbage loosely tomentose, the tomentum deciduous except from the leaf-axils: leaves once or twice pinnately parted into linear lobes: heads few, in a loose terminal cyme; peduncles 1 to $8 \mathrm{~cm}$. long: involucral bracts broadly oblong or narrowed to the base, very obtuse, nearly equal, tomentose on the back, the margins greenish-white: rays none: disk-flowers yellow, teeth reflexed: throat cylindric, narrowed to the nearly equal tube: villous hairs of the achene commonly as long as the pappuspaleae which barely equal the corolla-tube, or the paleae sometimes much shorter.

Providence Mts., Mohave Desert, Jun. 6, 1902, Brandegee; east to Nebraska. 
3. H. Wrightii, Hall, comb. nov. Hymenothrix Wrightii Gray, Pl. Wright. ii. 97 (1853).

Stems rigid, corymbosely branched, 2 to $10 \mathrm{dm}$. high, from a biennial or perennial root: herbage somewhat hirsute below, glandular or glabrous above, no woolly tomentum: leaves once or twice ternately divided into linear or filiform divisions : involucre ( 6 to $8 \mathrm{~mm}$. high) of obovate-oblong and very obtuse purple-tinged bracts and a few smaller narrow accessory ones: rays none: disk-flowers white or purplish, with very slender tube, short throat, and limb 5-parted into widely spreading lobes: style-tips flat, cuspidate: anthers exserted: achenes villous: pappus-paleae lanceolate, the strong midrib continued as a scabrous awn nearly equalling the corolla.

Pine Valley, San Diego Co., Alderson, acc. to Parish; Stonewall Mine, Cuyamaca Mt., San Diego Co., Brandegee; southern Arizona and Lower California.

\section{PALAF OXIA Lag.}

Ours a robust much branched herb of the Desert Area. Leaves alternate, entire. Heads narrow, discoid, the flowers either all alike or the outer corollas sometimes with very unequal lobes. Involucre of linear nearly equal bracts. Achenes nearly as long as the involucre, the slender pappus therefore much exserted.

1. P. linearis (Cav.) Lag., Nov. Gen. et Spec. 26 (1816); Hook., Bot. Mag. t. 2132 (1819). Ageratum lineare Cav., Ic. PI. iii. 3 , t. 205 (1794).

Flowering as an annual but becoming perennial and somewhat lignescent at base: herbage scabrous or hispid, the leaves canescent: leaves linear or linear-lanceolate, 2 to $6 \mathrm{~cm}$. long including the petiole-like base, acute, 1-nerved: involucre about $15 \mathrm{~mm}$. high; bracts linear, acute, lightly clasping the outer achenes: corolla-lobes 5, subequal or in the outer flowers often very unequal, one-half to one-fourth as long as the throat: pappus of 4 or 5 linear acute paleae nearly as long as the achene, traversed by a strong midrib and bordered with a membranous margin; in addition sometimes 2 to 4 shorter obtuse ones, or the paleae of the outer flowers sometimes all much reduced. 
Common in the Lower Sonoran Zone throughout the Colorado Desert: less common on the Mohave Desert, where it ranges as far north as Coso Mts., acc. to Coville; east into Arizona; south into Mexico.

\section{ERIOPHYLLUM Lag.}

Annual and perennial herbs or suffruticose plants. Herbage white-woolly, at least when young. Leaves mainly entire, or variously toothed, divided, or incised. Involucre oblong to hemispheric, its bracts distinctly rigid and permanently erect, concave and disposed to enfold the mature outer achenes. Receptacle flat or convex. Rays 4 to 13 or 15 , broad, rarely lacking. Tube of disk-corollas commonly glandular and hairy. Stylebranches from truncate to conical or subulate. Achenes linear or linear-clavate. Pappus various, sometimes lacking.

A.-Annuals: low (under $2 \mathrm{dm}$.) and diffuse.

Heads mostly sessile: receptacle flat or nearly so.

Rays $2 \mathrm{~mm}$. long

1. E. multicaule.

Rays none 2. E. Pringlei.

Heads pedunculate: receptacle convex or conical: rays conspicuous.

Achenes linear: leaves entire or toothed.

Pappus-paleae very unequal; about 5 short obtuse paleae alternating with as many longer awned ones 3. E. lanosum.

Pappus-paleae equal or wanting.

Anther-tips linear-subulate: tomentum copious, persistent

4. E. Wallacei.

Anther-tips obtuse or merely acute: tomentum less copious, deciduous

5. E. ambiguum.

Achenes clavate: leaves mostly pinnately parted

6. E. Heermanni.

B.-Biennials and perennials: taller (3 $\mathrm{dm}$. or more) and erect.

Heads small, terminally clustered: leaves mainly divided or parted.

Rays 6 to 10: stems mostly over $6 \mathrm{dm}$. high: maritime species.

Leaves green above: pappus-paleae 8 to 12 ...... 7 . E. staechadifolium.

Leaves white-tomentose on both sides: pappus-paleae 4 to 6

8. E. Nevinii.

Rays 4 or 5, or none: stems mostly under $6 \mathrm{dm}$. high

9. E. confertiflorum.

Heads large, solitary on long peduncles: leaves mainly entire: var. obovatum of

10. E. lanatum.

1. E. multicaule (DC.) Gray, Proc. Am. Acad. xix. 24 (1883). Actinolepis multicaulis DC., Prodr. v. 656 (1836); Hook., Ic. Pl. t. 325 (1841) ; Torr., Bot. Mex. Bound. 96, t. 33 (1859). 
Diffusely branched from the base, 2 to $10 \mathrm{~cm}$. high, often forming mats $1 \mathrm{dm}$. in diameter: floceulent tomentum deciduous except from the heads: leaves $1 \mathrm{~cm}$. or less long, broadly spatulate, mostly with 2 or 3 short rounded lobes or teeth at the apex: heads in leafy-bracteate close terminal clusters: involucre $3 \mathrm{~mm}$. high: receptacle nearly flat: rays 3 to 7 , yellow, $2 \mathrm{~mm}$. long: achenes sparsely pubescent, soon glabrate: pappus of 10 to 15 narrow somewhat fimbriate paleae, continued above into subulate awns, nearly as long as the corolla, sometimes lacking in part or all of the disk-flowers.

Common in Southern California west of the mountains and north to the upper Salinas Valley. Also in southern Arizona, acc. to Gray, and therefore to be expected in our Desert Area.

2. F. Pringlei Gray, Proc. Am. Acad. xix. 25 (1883). Actinolepis Pringlei Greene, Fl. Fr. 441 (1897).

Stem much branched from the base, forming dense woolly tufts 1 to $5 \mathrm{~cm}$. high and $15 \mathrm{~cm}$. or less in diameter : leaves and heads as in the last preceding but rays lacking: achenes appressed-pubescent: pappus-paleae silvery-scarious, broadly lanceolate, obtuse, erose, equalling the corolla-tube.

Plentiful in gravelly soil on the Mohave Desert and the surrounding mountains (even to $1800 \mathrm{~m}$. alt.) ; ranging west to Mt. Pinos, Ventura Co., Hall, no. 6322, north to the Greenhorn Range, Hall \& Babcock, no. 5075, and east into Arizona, acc. to Gray.

3. E. lanosum Gray, Proc. Am. Acad. xix. 25 (1883). Burrielia lanosa Gray, Pacif. R. Rept. iv. 107 (1857). Actinolepis lanosa Gray, Proc. Am. Acad. ix. 198 (1874).

Plant 4 to $10 \mathrm{~cm}$. high, the few to numerous branches ascending or erect: leaves linear, mostly entire, $1 \mathrm{~cm}$. or less long: heads scattered on more or less elongated naked peduncles: involucre narrow, 5 or $6 \mathrm{~mm}$. high: receptacle convex, obtuse: rays white or rose-color, $5 \mathrm{~mm}$. long: anther-tips subulate: style-branches obtuse: achenes sparsely pubescent : pappus of about 5 paleaceous awns nearly as long as the corolla and as many obtuse alternating paleae of half this length.

A rare species occurring from Lower California and along 
our eastern borders to southern Nevada; Needles, Feb., 1886, Mrs. Brandegee.

4. E. Wallacei Gray, Proc. Am. Acad. xix. 25 (1883). Bahia Wallacei Gray, Pacif. R. Rept. iv. 105 (1857). Actinolepis Wallacei Gray, Proc. Am. Acad. ix. 198 (1874).

Stem freely branching from the base; the branches ascending, 2 to $10 \mathrm{~cm}$. high: the copious matted wool tardily or not at all deciduous: leaves spatulate or obovate, obtuse, mostly entire, 1 $\mathrm{cm}$. or less long: heads short-pedunculate: involucre $5 \mathrm{~mm}$. high, its overlapping bracts not united: receptacle low-conical, obtuse: rays about 10, yellow, $4 \mathrm{~mm}$. long and nearly as broad: anthertips subulate: style-branches conical, acutish: pappus-paleae, 6 to 10 , oblong or obovate, obtuse, erose, one-half to one-fourth as long as the corolla.

In gravelly or sandy soil: San Bernardino Valley; San Jacinto Mts.; east to Arizona and southern Utah.

A form with the pappus reduced to a mere border comes from the Santa Ana River bottoms near Redlands, F. M. Reed, no. 784, and Greata, no. 572, part, but it passes into the typical form at the same locality. There is also a color form (Bahia rubella Gray) in which the rays are pale purple and white or even dull rose-color : western borders of Colorado Desert at San Felipe, San Diego Co., Parry, acc. to Gray, also Brandegee, and Apr. 25, 1899, Mrs. Brandegee; Vallecito, San Diego Co., Parish, no. 1625. It will probably be found that color characters are no more constant here than they are in Layia glandulosa, where analagous forms oceur.

5. E. ambiguum Gray, Proc. Am. Acad. xix. 26 (1883), and Syn. Fl. i. pt. 2, 330 (1884). Lasthenia (Monolopia) ambigua Gray, Proc. Am. Acad. vi. 547 (1865). Bahia parviflora and B. ambigua Gray, Bot. Calif. i. 382 (1876). E. paleaceum Brandegee, Bot. Gaz. xxvii. 450 (1889).

Annual, .5 to $3 \mathrm{dm}$. high: stem slender, ascending or erect, freely and widely branched, especially from the base: tomentum tardily deciduous from the leaves and stems: leaves alternate, narrowly oblanceolate or spatulate and obscurely few-toothed, or linear and entire, 1 to 2 or $4 \mathrm{~cm}$. long: peduncles 1 to $5 \mathrm{~cm}$. long, 
each bearing a solitary head: involucre usually $5 \mathrm{~mm}$. high ( 4 to $6 \mathrm{~mm}$.) ; its rigid carinate bracts about 8 , either distinct to the base or lightly united for about two-thirds the way up into a campanulate cup with ovate acute teeth: receptacle acutely conical, varying from chaffy to scrobiculate: rays about 5 to 10 , yellow, 4 to $10 \mathrm{~mm}$. long: disk-corollas funnel-form with a short cylindric glandular tube: anther-tips ovate, merely acute: stylebranches conical, acute: achenes linear, pubescent with appressed hairs: pappus commonly a mere crown of quadrate erose scales, sometimes conspicuous and lacerate, sometimes quite obscure or wanting.

Confined to the Desert Area and surrounding mountains, from Palm Springs, Riverside Co., to Fort Tejon, Kern Co., and Owens Valley, Inyo Co.

It would not be difficult to segregate a number of species from the aggregate $E$. ambiguum if one had only the extreme forms. An abundance of material shows, however, that species based on length and number of rays, union or separation of involucral bracts, character of pappus, and presence or absence of chaff on the receptacle, are neither natural nor of scientific value. Not only do these characters vary greatly, but they may be found in almost all possible combinations, the variations not being concommitant.

The original Lasthenia ambigua had united bracts, a "scrobiculate, rarely smooth" receptacle, and a coroniform pappus of short erose-truncate paleae. It came from near Fort Tejon, where I have recently re-collected it under no. 6297.

A similar form but with the bracts distinct and the rays hardly longer than the disk was described as Bahia parviflora from specimens gathered at the same station. It has not been re-collected.

$E$. paleaceum was based on specimens gathered at Kernville and Olancha. It combines distinct bracts, developed rays, and a short paleaceous pappus, with a chaffy receptacle, the upper paleae of which are persistent and become $1 \mathrm{~mm}$. long. Exactly the same form, except that the paleae of the receptacle are usually less numerous and smaller or quite obscure, is common in good seasons from the Argus and Panamint Mts. south to Fremonts 
Peak on the Mohave Desert (Hall \& Chandler, nos. 6856, 6873 , 6941, 7092), and reappears on the Colorado Desert at Palm Springs, where the receptacle is nearly or quite smooth (Parish, nos. 4120, 6088; Hall, no. 5760). This is perhaps the normal form of the species, it being common and widely distributed. In it the number of rays is normally 8 .

6. E. Heermanni (Durand) Greene, Fl. Fr. 445 (1897). Monolopia Heermanni Durand, Jour. Phila. Acad. ser. 2, iii. 93 (1855).

Slender, 1 to $3 \mathrm{dm}$. high, from an annual root, freely branched: herbage tomentose, tomentum deciduous from at least the stems at time of flowering : leaves alternate, mostly pinnately parted into several linear segments but the basal ones sometimes spatulate and merely toothed, the upper ones linear and entire: heads solitary, on peduncles 1 to $5 \mathrm{~cm}$. long: involucre about 5 $\mathrm{mm}$. high; bracts about 8 , united below the middle: receptacle conical, naked: rays 8 to 10 , yellow, 4 to $8 \mathrm{~mm}$. long: tube of disk-corollas glandular-pubescent: anther-tips ovate, acute: style-branches linear, obtuse: achenes clavate, 4-angled, pubescent: pappus none, or represented by 1 or more minute paleae, acc. to Greene.

On the Mohave Desert at Kramer, San Bernardino Co., May 30, 1892, Mrs. Brandegee; Sierra Nevada foothills of middle California.

7. E. staechadifolium Lag., Nov. Gen. et Spec. 28 (1816). Bahia artemisiaefolia Less., Linnaea vi. 253 (1831); Gray, Bot. Calif. i. 380 (1876). Lizard TaIL.

Robust, 6 to $9 \mathrm{dm}$. high: leaves pinnately parted into 5 or 7 lobes; these again pinnately parted, or toothed, or entire; the margins revolute and the under surface white with a dense feltlike tomentum, green and glabrous or lightly pubescent above: tomentum of the stems deciduous: heads disposed in close compact cymes: involucre broadly oblong or somewhat turbinate, 5 $\mathrm{mm}$. high; bracts linear, rigid, becoming carinate at base: rays 6 to 8 , yellow: pappus-paleae 9 to 12 , those at the angles of the achene longer.

Along the coast from Santa Barbara, ace. to Gray, and the 
Channel Islands, acc. to Brandegee, ${ }^{45}$ northward; near Santa Maria, Miss Eastwood, no. 837.

"Lagasca's original appears to have been a branch of the form with uppermost leaves entire.' -Gray. This form has been recollected by Heller, no. 6704, along the beach at Pacific Grove, Monterey Co., presumably the type locality. In Mr. Heller's specimens the main branches are woody and leafless, the twigs densely clothed with linear entire leaves. In the ordinary form only the small bract-like leaves of the inflorescence are entire.

8. E. Nevinii Gray, Syn. Fl. i. pt 2, 452 (1886).

Decidedly woody below, about $10 \mathrm{dm}$. high: leaves $15 \mathrm{~cm}$. or more long, ovate in outline, once or twice pinnately parted into numerous oblong obtuse lobes, equally white-tomentose on both sides: tomentum of the stems deciduous: heads numerous, crowded in naked-pedunculate broad flat-topped compound cymes: involucre cylindrical, 6 to $7 \mathrm{~mm}$. high; bracts oblong, obtuse, rather loose : rays 7 to 10 , yellow, short: pappus of 4 to 6 erose paleae, often unequal, the longer ones lanceolate and acute.

San Clemente Island, on rocks overhanging the sea, Apr., 1885, Nevin \& Lyon, acc. to Gray, Aug., 1894, Brandegee; Santa Catalina Island, on the sea-cliff, Jun., 1896, Mrs. Blanche Trask, May, 1890, Brandegee.

9. E. confertiflorum (DC.) Gray, Proc. Am. Acad. xix. 25 (1883). Bahia confertiflora DC., Prodr. v. 657 (1836).

Plant 2 to $6 \mathrm{dm}$. high : stem slightly woody at base, often unbranched: herbage with a close dense (at length deciduous) tomentum: leaves of the flowering branches $3 \mathrm{~cm}$. or less long, ternately or pinnately parted into 3 to 7 narrowly linear divisions: heads in compact terminal clusters : involucre obovoid-oblong, 4 mm. high: its bracts about 5, ovate : rays 4 or 5 , yellow, about 4 - mm. long: paleae 8 to 10, nearly equal, about one-half as long as the achene.

Abundant on dry hills from San Diego north throughout western California.

Var. trifidum (Nutt.) Gray, l. c. Bahia trifida Nutt., Trans. Am. Philos. Soc. ser. 2, vii. 374 (1841). Leaves small, entire

45 Zoe i. 139 (1890). 
except near the apex where they are cleft into 3 to 5 short linear lobes.-With the ordinary form and in the mountains to at least $2000 \mathrm{~m}$. alt.

Var. laxiflorum Gray, l. e. Leaves as in the species: heads more loosely cymose, the peduncles being mostly 5 to $10 \mathrm{~cm}$. long. -Also with the species; an uncommon form.

Var. discoideum Greene, Fl. Fr. 443 (1897). Stems more leafy : heads large, in congested cymes, destitute of rays.-First known from Sonoma Co.; since collected by Miss Alice King at Arroyo Grande, San Luis Obispo Co., and by Mrs. C. M. Wilder in the San Antonio Mts. at altitudes of 2100 to 2400 m., no. 594 . In Mrs. Wilder's specimens the leaves are palmately trifid and the involucres $6 \mathrm{~mm}$. high.

Var. latum Hall, var. nov. Leaves broadly spatulate or obovate ( 7 to $14 \mathrm{~mm}$. wide), with few very blunt and short lobes or the upper entire: heads mostly on evident peduncles: rays present.-Plains near Riverside, E. L. Koethen, no. 20 (type). Specimens collected at San Bernardino by S. B. \& W. F. Parish, May, 1888, also belong here.

10. E. lanatum obovatum (Greene) Hall, comb. nov. $E$. obovatum Greene, Eryth. iii. 123 (1895), and iv. 67 (1896).

Stems numerous, seldom branched, erect from a decumbent base or strong perennial root, 2 or $3 \mathrm{dm}$. high, not woody, terminated by solitary long-peduncled heads: herbage densely and permanently tomentose: leaves obovate to narrowly lanceolate, obtuse, either entire or the broader ones with several teeth or lobes, mostly $2 \mathrm{~cm}$. but the lower sometimes as much as $5 \mathrm{~cm}$. long: involucre 7 to $10 \mathrm{~mm}$. high, its rigid acute bracts more or less united at base : rays about 13 , broad, $1 \mathrm{~cm}$. long, deep yellow : achenes glabrous or nearly so: pappus variable, usually of about 8 short obtuse erose paleae, some of these rarely elongated and acute.

Not uncommon in the Transition Zone of the San Bernardino Mts. at 1200 to $2200 \mathrm{~m}$. alt. : Wright, no. 1811 (type of E. obovatum?); Parish, nos. 1086, 1451, 3344, 3714, 3716; Davidson; Hall, nos. 1070, 1289.5; etc.

In Mr. Wright's specimen and in some others the tomentum has a greenish-yellow tinge, while in some cases it is dull white. 
But specimens collected together, as under $H a l l$, no. 1289.5, exhibit both sorts of tomentum and intermediate shades occur. Mr. Wright's plant is the only one seen in which the longer lanceolate pappus-paleae occur. This var. can be distinguished from certain Sierran forms of $E$. lanatum Pursh ${ }^{45^{a}} \quad(=E$. caespitosum Dougl..$^{45^{b}}$ ) only by its larger size.

\section{AMBLYOPAPPUS H. \& A.}

Low annual with gummy sweet-scented herbage. Heads small, discoid, in loose elongated cymes and racemes terminating the simple erect stems. Involucral bracts 4 to 6 , rather broad, obovate-oblong. Receptacle small, conical. Achenes small, 4angled, narrowed below. Pappus of 8 to 12 oblong obtuse paleae, oftened colored.

1. A. pusillus H. \& A., Journ. Bot. iii. 321 (1841). Aromia tenuifolia Nutt., Trans. Am. Philos. Soc. ser. 2, vii. 396 (1841). Infantea Chilensis Remy, in Gay, Fl. Chil. iv. 259, t. 48, f. 1. (1849-1866).

Plant about 2 (rarely 5) dm. high: leaves alternate, linear, entire or the lower pinnately 3 to 5 -parted and sometimes opposite: involucres $3 \mathrm{~mm}$. high: flowers 5 to 25 (!), yellowish.

From Monterey, acc. to Parry, ${ }^{46}$ to Lower California and reappearing in Peru and Chile. Common near the sea from Los Angeles Co. to San Diego and on the islands from San Miguel ${ }^{47}$ to San Martin.

\section{RIGIOPAPPUS Gray.}

Slender annual with alternate linear leaves. Heads rather small, solitary, on filiform peduncles terminating the simple stems or branches. Bracts subulate, similar to the upper leaves. Receptacle flat. Flowers yellow, white, or purple. Pistillate flowers 5 to 15, their ligules scarcely or not exceeding the disk. Style-branches of the perfect disk-flowers with a slender-subulate hispidulous appendage. Achenes linear. Pappus of mostly 3 to 5 subulate awns, rarely wanting.

45a Pursh, Fl. ii. 560 (1814).

$45^{\mathrm{b}}$ Dougl., in Lindl., Bot. Reg. xiv. t. 1167 (1828).

46 Bot. Mex. Bound 96 (1859).

47 Acc. to Greene, Pitt. i. 90 (1887). 
1. R. leptocladus Gray, Proc. Am. Acad. vi. 548 (1865).

Slender, erect, a few $\mathrm{cm}$. to $3 \mathrm{dm}$. high: herbage short-hairy or nearly glabrous: involucre $6 \mathrm{~mm}$. high; bracts becoming concave around the ray-achenes: achenes hispidulous.

Upper Sonoran Zone: San Francisquito Cañon, Los Angeles Co., Hall \& Chandler, no. 7395; Santa Inez Mts., Santa Barbara Co., Brandegee; Cuyama, San Luis Obispo Co., May 7, 1896, Miss Eastwood; Fort Tejon and San Emigdio Potreros, Kern Co., Hall, nos. 6269, 6432; Tehachapi, Kern Co., Hasse \& Davidson, no. 1675 ; north to Washington and east to Nevada (Miss Stokes).

\section{CHAENACTIS DC.}

Annuals and low perennials with alternate pinnately parted or dissected or sometimes entire leaves and yellow or white flowers. Heads peduncled, solitary or eymosely arranged. Involucre campanulate; its bracts herbaceous, linear to lanceolate, commonly equal, in one series. Receptacle flat, naked. Corollas with short tube and long throat, or the marginal corollas in some species with the limb palmately enlarged, forming a kind of ray. Pappus of hyaline paleae, the paleae in the outer flowers commonly shorter and fewer, early deciduous or wanting in the last species.

\section{A.-Pappus-paleae persistent, entire or merely erose.}

Flowers yellow: annual

.1. C. glabriuscula.

Flowers white or purplish tinged.

Annuals.

Stamens exserted from the corolla-tube.

Pappus of disk-flowers of 4 equal paleae, or these sometimes unequal (paleae rarely 5 to 6 in $C$. Fremonti).

Involueral bracts setaceously acuminate ........2. C. carphoclinia. Involucral bracts obtuse or merely acute.

Leaves pinnatifid, with short thick lobes......3. C. stevioides. Leaves entire or with a few elongated slender lobes

4. C. Fremonti.

Pappus of 4 equal paleae about as long as corolla and 2 to 4 very small outer ones

5. C. Xantiana.

Stamens included

6. C. macrantha.

Perennials: pappus of 8 to 15 equal paleae.

Leaf-lobes crowded, crispate

7. C. santolinoides.

Leaf-lobes fewer, not erispate, mostly entire 8. C. Parishii. 


\section{B.-Pappus of deciduous fimbriate paleae or none.}

Achenes flat, obovate or clavate: glandular-pubescent annual

.. C. artemisiaefolia.

1. C. glabriuscula DC., Prodr. v. 659 (1836).

Annual, 1.5 to $5 \mathrm{dm}$. high, leafy up to the inflorescence, commonly branching only above: herbage thinly floceose, soon glabrate: leaves once or twice pinnately parted into linear lobes or the upper linear and entire : involucre 7 to $10 \mathrm{~mm}$. high ; its bracts broadly linear, with obtuse thickish tips: corollas pubescent throughout or the tube nearly glabrous; marginal corollas with ampliate palmate limb surpassing the disk: pappus-paleae 4 , rarely 5; those of the disk-achenes as long as the corolla, acute; those of the marginal achenes either as long as the corolla and acute or of varying lengths and the shorter ones obtuse.

Including its various forms and varieties, this species has a range extending from Lower California to the northern tier of counties in Alta California. It is very common west of the Sierra Nevada and San Bernardino Mts. and extends to the borders of the Desert Area. While apparently very easy to distinguish several well marked species when only a few specimens are at hand, this separation is seen to be inadvisable when the forms are studied in the field or when several hundred sheets from as many localities are examined. Pappus characters are here entirely unreliable and distinctions based on the size or shape of the marginal corollas are of no value. Perhaps the best characters are to be found in the involucre but here all intermediate stages between broad flat bracts with thick obtuse tips and linear deeply concave bracts with thin acute tips may be found, and the two forms often occur, moreover, in a single head.

Key to the Varieties and Forms of C. glabriuscula.

Stem branching only above, or also at base: peduncles never scape-like.

Involucral bracts narrowly oblong; their tips thick, obtuse: marginal corollas mostly with palmate limb.

Pappus-paleae of inner achenes about as long as the corolla, acute: typical c. glabriuscula.

Pappus-paleae all much shorter than the corolla, very obtuse and in two series; the outer minute. var. heterocarpha. in one series; all very short var. heterocarpha f. curta. 
Involucral bracts linear, acute: marginal corollas regular.

Leaf-lobes slender, elongated.

Stems and leaves moderately slender: the common form

var. tenuifolia.

Stems and leaves exceedingly slender: extreme form var. tenuifolia f. filifolia.

Leaf-lobes short, thick, obtuse: inflorescence glandular

var. Orcuttiana.

Stem branching only near the base: peduncles mostly elongated, the earlier ones scape-like: herbage lanate var. lanosa.

The typical form of this species is represented by such specimens as the following, all from middle California : Madera, Apr. 22, 1897, Setchell; Sierra foothills of Fresno Co., Apr. 3, 1898, Woolsey; Summerville, Contra Costa Co., Apr. 16, 1889, Chesnut \& Drew; Antioch, Contra Costa Co., Davy, no. 874; same locality, Mrs. Curran, no. 26. The following collections from Southern California approach very near to the typical form and may be classed with it: Bear Valley, Parish, no. 2013; Ballona, Los Angeles Co., Braunton, no. 429 (very robust with large heads and glandular inflorescence but passing through other forms gathered in the same locality by Mr. Braunton into var. tenuifolia); near Bardsdale, Ventura Co., Hall, no. 3238; Ojai Valley, Hubby, no. 86.

Var. heterocarpha (Gray) Hall, comb. nov. C. heterocarpha Gray, Pl. Fendl. 98 (1849). Disk-achenes with 4 unequal very obtuse elliptic-oblong paleae one-half as long as the corolla or longer, and 1 to 4 very short roundish outer ones or these obsolete; pappus-paleae of the ray-achenes all short.-Humboldt Co., Jul. 23, 1888, Chesnut \& Drew; San Bernardino Co., acc. to Gray, but there is no specimen in the Gray Herbarium from south of Ventura Co., ace. to Parish. ${ }^{47^{a}}$ J. P. Tracy has collected a form in Napa Co. (no. 1571) having disk-achenes with 5 principal pappus-paleae nearly as long as the corolla, and in addition an outer series of 5 short ones.

Var. heterocarpha f. curta (Gray) Hall, comb. nov. C. heterocarpha curta Gray, Syn. Fl. i. pt. 2, 452 (1886) ; Hall, Bot. Gaz. xxxi. 391 (1901). Heads often small : pappus of 4 or 5 oval or broadly oblong paleae, either equal or one of them longer but not

$47^{\text {a }}$ Zoe v. 119 (1901). 
exceeding one-half the length of the corolla, sometimes reduced to a mere crown; no outer series.-Western end Antelope Valley, Davy, no. 2661; Gorman Station, Jun., 1887, Parish; Estrella, San Luis Obispo Co., Jared (pappus very short, this form being therefore near C. Nevii Gray); Fort Tejon, Kern Co., Hall, no. 6310 ; near Cahuenga Peak, Los Angeles Co., Chandler, no. 2008 (very slender; some paleae elongated, acute); Greenhorn Mts., Kern Co., Hall \& Babcock, no. 5086; Box Springs Mt., near Riverside, Zumbro, no. 525. Mr. Zumbro's specimens beautifully combine the characters of this variety and the next. They possess exactly the habit and involucres of var. tenuifolia but the marginal corollas are enlarged and the limb palmate, as in $f$. curta. In the disk-flowers the pappus-paleae are 5 in number, one slightly longer than the others and nearly one-half as long as the corolla : ray-pappus short. My no. 6326, from Mt. Pinos, Ventura Co., has light-yellow or whitish flowers, suggestive of a hybrid origin between this variety and $C$. stevioides brachypappa.

Var. tenuifolia (Nutt.) Hall, comb. nov. C. tenuifolia Nutt., 'T'rans. Am. Philos. Soc., ser. 2, vii. 375 (1841). Slender in all its parts: leaves or their divisions usually filiform and elongated: involucre about $7 \mathrm{~mm}$. high; its bracts linear, thin, acute: marginal corollas often enlarged but seldom exceeding the disk or with palmate limb: pappus-paleae of disk-flowers equalling the corolla, acute; of the marginal flowers similar or much shorter and obtuse.-Very common, usually in light soil, from $1500 \mathrm{~m}$. alt. in the mountains to the Pacific and from Santa Barbara to San Diego - the original locality. The following collections may be selected as fairly typical of this variety: San Diego, Hall, no. 3937; San Jacinto Mt., Hall, nos. 2036, 2056; San Luis Rey, San Diego Co., Alderson, no. 1192; Santa Maria Rancho, San Diego Co., Parish, no. 1395; Mt. Pinos, Ventura Co., Hall, no. 6485. Specimens gathered near Riverside (Hall, no. 3800) are perhaps best referred here although some of the inner paleae are obtuse and the marginal corollas sometimes irregular, thus approaching the var. heterocarpha.

Var. tenuifolia f. filifolia (Gray) Hall, comb. nov. C. filifolia Gray, Pl. Fendl. 98 (1849). The most slender-leaved form, both 
rachis and lobes slenderly filiform.-Pala, San Diego Co., Parish, no. 4398; Witch Creek, San Diego Co., 1893, Alderson.

Var. Orcuttiana (Greene) Hall, comb. nov. C. tenuifolia Orcuttiana Greene, West Am. Sci. iii. 157 (1887). C. Orcuttiana Parish, Eryth. vi. 92 (1898). Stouter than var. tenuifolia : leaves 2 or 3-pinnatifid, the ultimate lobes short and obtuse: inflorescence resinous-glandular: involucre about $7 \mathrm{~mm}$. high; its bracts linear, acute: marginal corollas regular: pappus-paleae (at least in the disk) nearly equalling the corolla, acute.-Along the beach of. San Diego Co., passing directly into var. tenuifolia: North Island, Coronado, Chandler, no. 5168; Encinitas, Parish, no. 4435.

Var. lanosa (DC.) Hall, comb. nov. C. lanosa DC., Prodr. v. 659 (1836). Plant commonly 1 to $3 \mathrm{dm}$. high: stems leafy only at the branching base, bearing many long peduncles which are naked and scape-like: herbage whitish with floceose wool which is only tardily deciduous: leaves thickish, simply pinnate with few narrowly linear and mostly short lobes or the upper entire: marginal corollas usually little if at all ampliate, seldom exceeding the disk (yet sometimes conspicuously enlarged) : pappusraleae of disk-flowers 4 , sometimes 5 , equal or nearly equal, acutish.-Common in dry or sandy places throughout the Lower and Upper Sonoran zones of Southern California, except in the Desert Area; north to Stockton. The extreme form of this variety, with a somewhat persistent lanate tomentum and large heads terminating simple seape-like peduncles from the much branched very leafy base, is represented by such collections as the following: San Jacinto Mt., Hall, nos. 1141, 2165; Mohave River district, Parry \& Lemmon, no. 200 ; Naseimiento River, Monterey Co., Brewer, no. 541, also May, 1901, Miss Eastwood. It passes, however, by insensible gradations as regards all its characters into the var. temifolia, and plants with all the other characters of var. lanosa sometimes have irregular marginal corollas almost as large as in typical $C$. glabriuscula. The involucral bracts are always narrower than in the species and somewhat acute.

2. C. carphoclinia Gray, Bot. Mex. Bound. 94 (1859).

Annual, $3 \mathrm{dm}$. or less high, the slender stem cymosely branched: herbage cinereous-pubescent, not at all woolly: leaves 
once or twice pinnately parted into narrow lobes: heads numerous, on short filiform peduncles: involucre about $8 \mathrm{~mm}$. high; bracts linear-lanceolate, tapering into setaceous often pinkish awns : receptacle with 5 to 10 rigid persistent awns nearly equalling or even exceeding the flowers: paleae of disk-achenes usually 4, narrow, acuminate, nearly equalling the flowers, or some much shorter and obtuse; paleae of marginal achenes all short and sometimes much reduced.

Common in the Lower and Upper Sonoran zones from Inyo Co. across the Mohave and Colorado deserts to Utah, Arizona, and Lower California and ascending the desert side of the mountains to $2000 \mathrm{~m}$. alt. : Swansea and Independence, Inyo Co., Hall d: Chandler, nos. 7173, 7307; Morongo, Colorado Desert, Parish, no. 769 ; Upper Lake, Bear Valley, San Bernardino Mts., Parish, no. 1833; Mohave Desert, Hall, no. 6048; Colorado Desert, Hall, nos. 5809, 5847, 5904; Signal Mt., Colorado Desert, Brandegee; Gold Mt., Nevada, 1500 to 1800 m. alt., Purpus, no. 6002; Calamajuet, Lower California, Brandegee, in part; etc.

Var. attenuata (Gray) Jones, Proc. Calif. Acad. ser. 2, v. 699 (1895). C. attenuata Gray, Proc. Am. Acad. x. 73 (1874); Coville, Contr. U.S. Nat. Herb. iv. 134 (1893). Pappus-paleae of even the central flowers very short and obtuse, erose, or some of them acute but not more than one-third the length of the corolla : fimbrillae of the receptacle said to be few in number, but often numerous in otherwise typical plants.-Ehrenberg, Arizona, 1874, Janvier; Death Valley, ace. to Coville; Independence, Inyo Co., Hall \& Chandler, no. 7307 (paleae quadrate, minute) ; Borrego Springs, Colorado Desert, Apr. 17, 1895, Brandegee; San Felipe, Colorado Desert, Brandegee; Calamajuet, Lower California, Brandegee (with some paleae acuminate and one-half as long as corolla, others, even on same achene, very short and obtuse).

3. C. stevioides H. \& A., Bot. Beech. 353 (1840).

Annual, a few $\mathrm{cm}$. to 2 or $3 \mathrm{dm}$. high: herbage clothed with a light tomentum which is somewhat deciduous, leaves once or twice pinnately parted into numerous linear lobes which are only $7 \mathrm{~mm}$. or less long, or a few of the upper leaves entire: heads scattered on short slender peduncles: some of the marginal co- 
rollas commonly more or less enlarged : involucre 6 to $9 \mathrm{~mm}$. high; bracts obtuse or merely acutish, the midrib obtuse: pappus-paleae of the disk-achenes 4 , oblong-lanceolate, in the typical form nearly equalling the corolla and acute.

Lower Sonoran Zone of the Colorado and Mohave deserts, east to Arizona, north to Idaho; very common and mostly typical in the eastern part of the Colorado Desert, less plentiful in the western and northern parts of the Mohave Desert, where it grades into the var. brachypappa. Specimens examined: Colorado Desert, Hall, nos. 5903, 5935, 6018; Ash Hill, Mohave Desert, Hall, no. 6099; Antelope Valley, Hall, no. 3033; Morongo, Colorado Desert, Parish, no. 1213; Catalina Mts., Arizona, Lemmon, no. 194; Diamond Creek Cañon and near Kingman, Arizona, Wilson; Diamond Valley, Utah, Goodding, no. 891.

Var. brachypappa (Gray) Hall, comb. nov. C. brachypappa Gray, Proc. Am. Acad. viii. 390 (1873). Leaf-segments thick and short, obtuse: marginal corollas not enlarged: pappus reciuced to a mere crown of obtuse erose paleae or in the central flowers one of these often twice as long as the others, but even then less than $1 \mathrm{~mm}$. long.--Near Independence, Inyo Co., S. W. Austin, no. 500 ; southeastern Tulare Co., in the Piñon belt between Kernville and Cannell Meadows, about 1500 m. alt., Hall \& Babcock, no. 5101; Panamint Mts., Inyo Co., Coville \& Funston, no. 532, also Hall \& Chandler, no. 6947; Cuddy Valley, northeastern Ventura Co., Hall, no. 6318; Frazier Mt., Ventura Co., in the Transiton Zone (!), Hall, no. 6608; Colorado Desert, Hall, no. 5874 ; Maturango Range, Purpus, no. 5457 ; Lone Pine, Brandegee; Johannesberg and Ord Mts., Hall \& Chandler, nos. 6876, 6778. The pappus in the extreme form is very different from that in typical C. stevioides, but, as shown under C. Fremonti, pappus characters are of little specific value in this group. My no. 3033 , eited under the species, is an intermediate form, the diskpappus consisting of 3 rather obtuse paleae one-half as long as the corolla and an additional one commonly a little longer and acutish. The series is completed by my nos. 5874 and 6318 in which the pappus consists (in central flowers) of 3 obtuse paleae nearly as short as in typical brachypappa and a fourth palea about onehalf as long as the corolla and either obtuse or acute. 
4. C. Fremonti Gray, Proc. Am. Acad. xix. 30 (1883).

Annual, either slender or robust, .5 to $4 \mathrm{dm}$. high, branching: herbage slightly woolly when young but early glabrate except the puberulous or tomentose peduncles and involucres: leaves 2 to $5 \mathrm{~cm}$. long (rarely even $1 \mathrm{dm}$.), narrowly linear and entire, or once pinnately parted into similar lobes: heads terminating simple erect peduncles : involucral bracts broadly linear, acutish, with prominent midrib: marginal corollas often much enlarged and irregular, sometimes developing a cuneate 4 to 5 -cleft ligule: pappus of central achenes usually of 4 to 6 slender acute paleae nearly equalling the corolla, sometimes of 1 long and several shorter paleae, these often of varying lengths and either acute or obtuse; pappus of marginal flowers also variable but mostly of 1 long acute palea and 3 short obtuse seales.

Chiefly in the Lower Sonoran Zone of the Mohave and Colorado deserts, north to Bakersfield, east to Arizona : Coyote Cañon. Colorado Desert, Hall, no. 2807 and no. 2807a ; east base San Jacinto Mt., Jepson \& Hall (Hall, no. 1850) ; from near Palm Springs to Whitewater, Colorado Desert, Parish, nos. 343, 4119; same locality Gilman, no. 33, also Copeland; above Whitewater, Schellenger, no. 76; Antelope Valley, Mohave Desert, Hall, no. 3032 (Palmdale) and no. 3042 (Rock Creek); desert slope Cajon Pass, Hall, no. 6215; Santa Ana Cañon, San Bernardino Mts., at $2100 \mathrm{~m}$. alt. in the Transition Zone (!), Hall, no. 7574 (very rare at this altitude) ; Argus Mts. and Bishop Creek, Inyo Co., Hall \& Chandler, nos. 6898, 7240; Bakersfield, Davy, no. 1891; Needles, eastern San Bernardino Co., Miss Warner, no. 26; Fort Mohave, Arizona, Cooper; etc.

The variation in this species, as exhibited by the specimens cited above, is remarkable. The disk-pappus commonly consists of 4 equal lanceolate acute paleae about as long as the corolla, while the marginal achenes have one of these long paleae and 3 short obtuse scales. But the following deviations occur: $(a)$ two or three of the paleae reduced and obtuse in some of the inner flowers ( Hall, nos. 1850, 3042); (b) all the achenes, marginal as well as central, with 4 long acute paleae (Cooper); (c) some of the marginal achenes with 4 long equal paleae, some with 1 long palea and 3 short obtuse unequal ones (Parish, no. 4119, 
Copeland, Miss Warner, no. 26); (d) central achenes with 4 to 6 slender paleae about as long as corolla ( $\mathrm{Fall}$, no. 3032, and paleae sometimes 5 in Davy, no. 1891); (e) all the achenes with 1 long acute palea and 3 short ones, the latter of varying lengths and attenuate to obtuse ( $\mathrm{Hall}$, no. 2807a). It is a common occurrence for the flowers of the second circle from the involucre to have paleae of several different lengths on a single achene. Since such numerous variations as those enumerated above are found in plants growing near together, and even within single heads of some plants, pappus characters can be of no value in separating species of this group. It should be noted, however, that an outer series of paleae occurs only in C. Xantiana and C. macrantha, two species also well marked by other characters.

5. C. Xantiana Gray, Proc. Am. Acad. vi. 545 (1865); Hall, Bot. Gaz. xxxi. 391 (1901). C. Xantiana integrifolia Gray, Bot. Calif. i. 390 (1876).

A stout and somewhat fistulous-stemmed annual, 1.5 to $3 \mathrm{dm}$. high: herbage early glabrate, except on the involucres and peduncles, which commonly retain a slight woolliness : largest leaves 4 to 8 or $10 \mathrm{~cm}$. long, all linear and entire or usually once-parted into similar lobes: heads scattered on stout commonly fistulous peduncles: involucral bracts extremely variable, sometimes shorter than the disk, often with spreading obtuse foliaceous tips much exceeding the disk, traversed by 1 strong nerve and several obscure ones: flowers white or flesh-colored, the marginal ones scarcely enlarged: inner paleae of the pappus as long as or longer than the flowers; outer paleae conspicuous, obtuse, as broad as long.

Common in and around Antelope Valley from the Mohave River to Mt. Pinos, Ventura Co., and Fort Tejon, Kern Co., ascending the mountains to $2200 \mathrm{~m}$.; north along the eastern base of the Sierra Nevadas to Oregon. This species and C. Fremonti are much alike in general appearance and exhibit similar ecological variations but differ in pubescence, in the pappus, and in the involucre, the bracts of which have a strong tendency to end in foliaceous tips in C. Xantiana. In alkaline soil the plants become more robust and succulent, and the involucral bracts and pappus much elongated. 
6. C. macrantha Eat., Bot. King Exped. 171, t. 18 (1871).

Annual, commonly $2 \mathrm{dm}$. or less high, much branched from the base: herbage floccose-tomentose, glabrate at least below: leaves 2 to $4 \mathrm{~cm}$. long, the expanded upper portion 1 to 2-pinnatifid with oblong lobes, or the uppermost entire: heads shortpeduncled, or the earlier on long peduncles : involucre nearly 15 $\mathrm{mm}$. high; the loose bracts linear, acuminate but obtuse at the very tip, strongly 1-nerved : corollas flesh-color, much exceeding the involucre, the marginal not appreciably enlarged: anthers included: pappus of 4 oblong-linear paleae only half as long as the corollas and 2 to 4 very short oblong-cuneate outer ones, or these sometimes obsolete.

Originally known from Nevada and Utah but now collected at the following stations in the Lower Sonoran Zone of the Mohave Desert: Cushenberry Springs, Parish, no. 1255; Camp Cady, Parish, no. 1256; Newberry and Daggett, Hall, nos. 6138, 6828; Barstow, Mrs. Brandegee; Keeler, Brandegee. It also comes from Tueson, Arizona, W. F. Parish, no. 122, and is probably widely distributed over the Desert Area, although nowhere very common. Mr. Mareus E. Jones has noted ${ }^{48}$ that the flowers are more expanded at night than during the day.

7. C. santolinoides Greene, Bull. Torr. Club ix. 17 (1882); Gray, Syn. Fl. i. pt. 2, 341 (1884).

Stems scapose, 1 to $3 \mathrm{dm}$. high, mostly simple and numerous, from a perennial lignescent base: herbage densely and permanently white-tomentose below, glandular-pubescent above: leaves crowded on short tufted basal shoots, 3 to $10 \mathrm{~cm}$. long, narrowly oblong in outline with many obtusely few-lobed crispate divisions, these oblong and only a few $\mathrm{mm}$. long: involucre 10 to 13 $\mathrm{mm}$. high; its bracts oblong, obtuse, obscurely nerved, a few of the outer ones commonly very short and spreading: achenes densely hispid: pappus-paleae 8 to 10 , a little shorter than the corolla.

Dry gravelly slopes of the Transition Zone, rarely in the Upper Sonoran; not common: near Talmadge's Mill, Little Bear Valley, San Bernardino Mts., Parish, no. 1045 (type collection);

48 Zoe v. 41 (1900). 
Bear Valley, Parish; Fish Creek, Grinnell; San Antonio Mt., Mrs. Wilder, nos. 257, 592 ; Mill Creek Falls, Parish, no. 2515; Swartout Cañon, San Antonio Mts., 1900 m. alt., Hall, no. 1508; Wilsons Peak, San Gabriel Mts., McClatchie, Grant, no. 164; Mt. Gleason, San Gabriel Mts., 2000 m. alt., Barber, no. 269; Pah Ute Peak, Southern Sierra Nevada Mts., 1500 to 2100 m. alt., Purpus; Mt. Pinos, Ventura Co., Hall, nos. 6321, 6646, 6671; Frazier Mt., acc. to Coville.-Mr. Parish informs me that the type material certainly came from Little Bear Valley, although probably labeled "Bear Valley." He did not submit any specimens from Bear Valley to either Dr. Gray or to Professor Greene until after the publication of the species.

8. C. Parishii Gray, Proc. Am. Acad. xx. 299 (1885).

Low bush-like plants often several $\mathrm{dm}$. in diameter; the base perennial and suffrutescent; the annual branches numerous, erect, 2 to $5 \mathrm{dm}$. high, leafy only below, merely bracteate above, where they either branch and bear 2 or 3 long-pedunculate heads or are simple and monocephalous: herbage very white with close wool, glabrate only above: leaves 2 to $5 \mathrm{~cm}$. long (including the broad petiole of half this length); the blade oblong in outline, pinnately parted into obtuse linear lobes about $5 \mathrm{~mm}$. long, these rarely toothed: involucre 12 to $15 \mathrm{~mm}$. high; its very unequal bracts loose, linear, obtuse : pappus-paleae 9 to 15 , linear, nearly as long as the corolla.

Western borders of the Colorado Desert, south to Lower California; ascending the mountains to $2100 \mathrm{~m}$. alt. but only where the conditions are influenced by hot and dry ascending aircurrents from the desert: Aguanga, San Diego Co., Parish, no. 1396 (duplicate type); Coyote Cañon, Santa Rosa Mt., $1500 \mathrm{~m}$. alt., Hall, nos. 1178, 1901, 2128; Tahquitz Peak, San Jacinto Mt., Hall, no. 2326; Cuyamaca Peak, Brandegee.

That this species cannot be separated from C. suffrutescens, with which it was first confused, by the number of pappus-paleae, is shown from the fact that in our southern species this number varies from 9 to 15 , while in $C$. suffrutescens it is 9 or 10 . Moreover, the paleae of $C$. Parishii are often toothed or even cleft onehalf or two-thirds of the way down and this splitting is undoubt- 
edly sometimes continued to the base, thus producing 2 distinet paleae from one. But the paleae are always much narrower and less obtuse than in $C$. suffrutescens. C. suffrutescens has been re-collected (Jul., 1887, Brandegee, also Hall \& Babcock, no. 4081) at what Mr. Lemmon, the discoverer of the species, informs me is probably the type locality, namely, upper Shasta Valley at about $1200 \mathrm{~m}$. alt., and Mr. Lemmon has permitted me to examine the original specimens also. Although the pappus characters are unsatisfactory, there are others which clearly mark C. Parishii as a distinet species, particularly the smaller leaves and their shorter divisions and the lack of all glandular pubescence; the peduncles and involucres of $C$. suffrutescens being minutely but densely glandular after the fall of the tomentum. In the latter species the involucral bracts are inclined to end in foliaceous tips sometimes exceeding the disk, after the manner of C. Xantiana, a tendency not yet observed in C. Parishii.

9. C. artemisiaefolia Gray, Proc. Am. Acad. x. 74 (1874). Acarphaea artemisiaefolia Gray, Pl. Fendl. 98 (1849); Bot. Mex. Bound. 95, t. 32 (1859). Chaenactis lacera Greene, Pitt. i. 291 (1889).

Erect from a perpendicular annual taproot, 3 to $15 \mathrm{dm}$. high, simple below, branching above into a rather open leafless often paniculate cyme: herbage furfuraceous-pubescent below, viscid and glandular-hirsute above: leaves sometimes $2 \mathrm{dm}$. long and two-thirds as wide but usually only half this size, 2 to 3-pinnately divided and parted, the ultimate divisions numerous and irregularly oblong or linear: involuere about $1 \mathrm{~cm}$. high; its bracts linear-lanceolate, acute: flowers white: achenes attenuate at base, flat, glabrous or nearly so: pappus of deciduous fimbriate paleae or usually none.

Rather common in the Upper Sonoran Zone away from the sea; from the Sierra Santa Monica to San Jacinto and south into Lower California. Apr.-Jul. An exceedingly robust form has been collected by Mr. Ernest Braunton in the Cahuenga Hills, near Los Angeles (no. 273). One plant measures $16 \mathrm{dm}$. in height, some of the leaves are over $2 \mathrm{dm}$. long, and the involucral bracts are strongly reddish-tinged. 
Orochaenactis thysanocarpha (Gray) Coville, of the southern Sierras is to be looked for in the Tehachapi Mts. It is a slender annual with linear entire leaves, yellowish discoid heads, clavate-obovate achenes, and a deciduous pappus of 8 or 9 spatulate paleae fimbriate nearly to the base. It has an exact synonym in Bahia Palmeri Wats., Proc. Am. Acad. xxiv. 83 (1889), as a]ready pointed out by Mrs. Brandegee in Zoe v. 142 (1901).

\section{HULSEA T. \& G.}

Biennial or perennial montane herbs. Leaves alternate, sessile, scattered or in many species mainly basal. Heads rather large, yellow or purple, solitary or paniculate. Involucral bracts in 2 or 3 series, narrow, acute. Receptacle flat. Style-appendages of hermaphrodite flowers obtuse. Achenes linear-cuneate, compressed, soft-villous especially on the margins. Paleae of the pappus mostly 4 , from nearly entire to lacerate at the truncate summit.

Floccose-woolly when young: upper leaves reduced and bract-like: rays yellow to saffron.

Leaves mostly green at time of flowering, the tomentum deciduous: rays 12 to $20 \mathrm{~mm}$. long 1. H. Californica.

Leaves white-tomentose, the tomentum usually permanent: rays not over $15 \mathrm{~mm}$. long, or wanting

2. H. vestita.

No woolly pubescence, very glandular: upper leaves not bract-like: rays saffron

3. H. heterochroma.

1. H. Californica T. \& G., Bot. Mex. Bound. 98 (1849).

Robust biennial, 6 to $9 \mathrm{dm}$. high, leafy throughout: herbage clothed with a loose woolly tomentum when young, this deciduous with age exposing the glandular hairs : lower leaves ample, spatulate, the upper ones lanceolate to linear: heads several, in a leafybracted panicle: involucre 12 to $17 \mathrm{~mm}$. high: rays very numerous, 12 to $15 \mathrm{~mm}$. long: pappus-paleae erose-denticulate at the truncate summit.

Mountains of Southern San Diego Co. and Lower California, not common: near Campo, Parish, no. 297; San Pedro Martir, Brandegee.

2. H. vestita Gray, Proc. Am. Acad. vi. 547 (1865). $H$. Parryi Gray, l. c. xii. 59 (1876). 
The typical form with several to numerous simple scape-like stems 1 to $2 \mathrm{dm}$. high from a stout perennial root: leaves mainly basal, oblanceolate or obovate, 2 to $6 \mathrm{~cm}$. long, about $1 \mathrm{~cm}$. or less broad near the obtuse summit, entire or sinuate-dentate, clothed with a heavy permanent white tomentum: heads commonly solitary on the viscid-pubescent scapes which usually bear a few linear bracts: rays 20 to 30 (sometimes very few or wanting), linear-oblong, short, yellow or saffron: pappus-paleae toothed.

Mono Craters, Brewer, no. 1824, and Soda Springs of the San Joaquin, Congdon, south to Southern California whence the following collections, all from the Transition Zone: Frazier Mt., Ventura Co., Hall, no. 6598; San Bernardino Mts., Grinnell, no. 14, and Parish, nos. 1833, 3380.-Like the other species of Hulsea, $H$. vestita grows only in loose gravelly soil.

Var. pygmaea Gray, Syn. Fl. i. pt. 2, 343 (1884). Much depressed, the heads sessile or subsessile in the tuft of basal leaves: rays perhaps always saffron.-In the Canadian, Hudsonian, and Alpine zones of San Gorgonio and neighboring peaks of the San Bernardino Mts.; also on Mt. Whitney and perhaps elsewhere in the High Sierra Nevadas. A series gathered at many places in the San Bernardino Mts. shows the variation to be gradual and strictly altitudinal. Subsessile and long-pedunculate heads sometimes occur on the same plant.

Var. callicarpha Hall, Univ. Calif. Pub. Botany i. 129 (1902). H. callicarpha Wats., in Gray, Syn. Fl. i. pt. 2, 342 (1884), as synonym. El CAPARossa. Stems from an annual or biennial root, loosely branched above; the whole plant 2 to 6 or $8 \mathrm{dm}$. high: leaves mainly basal but also scattered along the branches, passing above into small bracts of the elongated peduncles : rays yellow, sometimes with a purplish base, $12 \mathrm{~mm}$. or less long.Open hillsides and beneath pines, often in sand-washes, at 1200 to $2700 \mathrm{~m}$. alt. in the Lower Transition (and Upper Sonoran?) zones of the San Jacinto, Palomar, and Cuyamaca Mts. A form from the summit of Mt. Gleason, San Gabriel Range, Barber, no. 261 belongs here although the root is sometimes perennial. Owing to the wide range of climatic and other conditions, it is not unusual for plants which are normally annual to become biennial or even perennial with us. 
3. H. heterochroma Gray, Proc. Am. Acad. vii. 359 (1868).

Robust, 5 to $15 \mathrm{dm}$. high, from an annual root: herbage very viscid, exhaling a rank disagreeable odor: leaves oblong, strongly dentate, the largest sometimes $15 \mathrm{~cm}$. long: heads racemosely disposed on the simple ascending branches: involucral bracts lanceolate, attenuate, about $15 \mathrm{~mm}$. long: rays 50 to 60 , narrowly linear, purple, usually conspicuous but said to be sometimes inconspicuous or obsolete: disk-corollas yellow; tube hirsute: pappus-paleae unequal, lacerate.

At middle altitudes on the San Jacinto and San Bernardino Mts., north to the Yosemite; also in the Coast Ranges of Monterey Co., ace. to Brandegee $;^{49}$ rarely collected.

\section{TRICHOPTILIUM Gray.}

Low and spreading floccose-woolly desert annual with alternate (or the lower opposite) leaves. Heads yellow, discoid, scattered on slender ascending peduncles. Involucre hemispheric; bracts about 20, nearly equal, those of the outer series ovatelanceolate and acute, the thin inner ones narrowly spatulate and often obtuse. Corolla with very short proper tube and elongated throat, the short lobes pubescent externally, spreading; outer corollas slightly enlarged: style-branches linear, obtuse. Achenes oblong-turbinate, villous. Pappus-paleae 5, much cut into unequal slender fimbriae, the middle ones approximating the corolla.

1. T. incisum Gray, Bot. Mex. Bound. 97 (1859). Psathyrotes incisa Gray, Pl. Thurb. 322 (1854).

Plant 1 to $1.5 \mathrm{dm}$. high: leaves 1 to $5 \mathrm{~cm}$. long, narrowly spatulate to obovate, narrowed below to a margined petiole, more or less incised-dentate with acute teeth: peduncles about $5 \mathrm{~cm}$. long on the larger plants, glandular-pubescent, not woolly: involucre 6 to $8 \mathrm{~mm}$. high; outer bracts ovate-lanceolate, acute.

Lower Sonoran Zone, in stony soil or in eracks of rocks : Colorado Desert (Coyote Cañon, Palm Springs, Indio Mt., Chuckawalla Bench, Signal Mt., etc.) to Arizona and Lower California. Probably also in the southeastern part of the Mohave Desert, since it comes from Ft. Mohave, Arizona. In some specimens

49 Zoe iv. 154 (1893). 
the pappus and achenial hairs are reddish-brown, in others white, but no other difference ean be detected.

\section{HYMENOXYS Cass.}

Herbaceous plants with aromatic herbage, alternate leaves, and pedunculate heads. Ray-flowers pistillate or the heads homogamous. Bracts of the involucre in two series, in our species the narrow and rigid outer bracts united at base into a shallow cup enclosing the broadly oblong obtuse inner ones. Flowers yellow. Achenes turbinate, hairy. Pappus of 5 to 12 conspicuous hyaline paleae.

For reasons stated by Dr. Cockerell in his revision of the North American Species of Hymenoxys, ${ }^{50}$ it seems advisable to unite Hymenoxys and Picradenia into one genus. The oldest tenable name for this group is Hymenoxys Cass. (1828), Pieradenia Hook. dating from 1834. This group cannot take the name Actinella, since Actinella Nutt. (1818) is apparently a distinct genus, distinguished by habit and involucre (=Tetraneuris Greene, Pitt. iii. 265). There is also an earlier Actinella Pers. (1807), the only species of which is now referred to Cephalophora (Gray says wrongly so referred).

Leaves pinnatifid.

Pappus-paleae very obtuse, erose at summit

1. H. Cooperi.

Pappus-paleae acuminate or cuspidate.

Involuere hemispheric, about $12 \mathrm{~mm}$. broad; outer bracts 12 to 14 .....

2. H. biennis.

Involuere eampanulate, 6 to $9 \mathrm{~mm}$. broad; outer bracts 8 to 10: var. excurrens of

3. $H$. chrysanthemoides.

Leaves entire

4. H. latissima.

1. H. Cooperi (Gray) Ckll., Bull. Torr. Club xxxi. 495 (1904). Actinella Cooperi Gray, Proc. Am. Acad. vii. 359 (1868).

Plant $6 \mathrm{dm}$. or more high, the stems paniculately branched above: herbage puberulent: leaves much parted into nearly filiform lobes: involucre nearly hemispheric; outer bracts 6 to 10 : achenes densely covered with ferruginous hairs: pappus-paleae 5 , of firm texture, ovate or oblong, with very obtuse erose summit, not half the length of the disk-corolla.

50 Cockerell, Bull. Torr. Club xxxi. 461 (1904). 
Providence Mts., Mohave Desert, at 1500 m. alt., 1860-61, Cooper, ace. to Gray; this is the only collection of the typical form, but several subspecies or varieties have been found in Arizona by Lemmon, Wilcox, MacDougal, and others.

2. H. biennis (Gray) Hall, comb. nov. Actinella biennis Gray, Proc. Am. Acad. xiii. 373 (1878). Hymenoxys canescens biennis Ckll., Bull. Torr. Club xxxi. 482 (1904).

Plant 4 to $6 \mathrm{dm}$. high: stem stout, much branched, probably from a biennial root: herbage puberulent or green and glabrate: leaves divergent, numerous at base, scattering above, simply 3 to 5 -parted into narrow linear lobes: heads loosely cymose: involucre hemispheric, 10 or $12 \mathrm{~mm}$. broad; outer bracts 12 to 14 , acuminate, nearly distinct; inner bracts slightly longer, with short subulate tips: rays 12 to 14,12 to $25 \mathrm{~mm}$. long: achenes with ferruginous hairs: pappus-paleae ovate-lanceolate or cuspidate, about half as long as disk-corolla.

Providence Mts., Mohave Desert, Brandegee; Arizona to Utah.

3. H. chrysanthemoides excurrens Ckll., Bull. Torr. Club xxxi. 501 (1904).

Three to $6 \mathrm{dm}$. high: stem striate, much branched, from a strong annual taproot: herbage minutely pubescent, the growing parts somewhat tomentose: leaves 2 to $5 \mathrm{~cm}$. long, 3 to 5 -parted into nearly filiform lobes which are sometimes again divided: heads numerous, scattered on elongated peduncles: involucre campanulate or almost cylindric, 5 to $9 \mathrm{~mm}$. broad; outer bracts about 8 , lanceolate, rigid, $5 \mathrm{~mm}$. long; inner bracts ovate and slightly longer, entire: rays 8 to 10 (rarely 11 or 12), yellow, 7 to $10 \mathrm{~mm}$. long, merely toothed at apex: pappus-paleae ovate, pointed, two-thirds the length of the corolla.

Abundant on overflow land of Paloverde Valley, Riverside Co.; Schellenger, no. 10, and Hall, no. 5914. Also near Yuma, on the Arizona side of the Colorado River, Vasey, acc. to Cockerell, and Parish, no. 198. Perhaps plentiful along the river both north and south of these localities, which are within the Lower Sonoran Zone.

4. H. latissima Ckll., Bull. Torr. Club xxxi. 498 (1904).

Herbage glabrous save for some loose white hairs: cauline 
leaves sessile, elongate-oval, acute, entire, about $3 \mathrm{~cm}$. long : heads on slender peduncles, hemispheric, about $2 \mathrm{~cm}$. broad excluding rays, very woolly at base: inner bracts with long-pointed tips: receptacle high-conic, obtuse: achenes pubescent: pappus-paleae white, nearly three-quarters as long as disk-corolla, long-pointed, the tip sometimes bifid.

Known only from a scrap in the herbarium of Dr. E. L. Greene, labeled as coming from Southern California and communicated by Prof. Wickson; but possibly not Californian.

H. RichardsoniI (Hook.) Ckll., in some of its forms, is to be looked for along our northeastern borders. Stems usually low ( $2 \mathrm{dm}$. or less), from large perennial roots : leaves pinnatifid, the radical with wool in their axils : pappus-paleae long-acuminate or aristate.

H. FLORIBUNdA Utilis Ckll. is the Colorado Rubber Plant, at home in the mountains of Colorado and New Mexico. All parts of the plant, but especially the thick yellow roots and stems, yield a caoutchouc-like substance.

\section{HELENIUM L. SNEEZEWEED.}

Erect herbs, ours perennial and with resinous-dotted foliage. Leaves alternate, sessile except the lower, often decurrent on the stem. Heads solitary or cymose, borne on long naked peduncles. Flowers yellow, or the lobes of the disk-corolla turning yellowish or brownish, either all perfect or the ray-flowers pistillate or neutral. Rays several, usually drooping. Bracts of the involucre linear, reflexed. Receptacle globose or hemispheric, naked. Achenes turbinate, ribbed. Pappus of 5 to 12 thin or hyaline paleae, in ours short-pointed.

Rays shorter than the disk, 2 to $8 \mathrm{~mm}$. long. 1. H. puberulum. Rays equalling or longer than the disk, 10 to $20 \mathrm{~mm}$. long 2. H. Bigelovii.

1. H. puberulum DC., Prodr. v. 667 (1836). Heleniastrum puberulum Ktze., Rev. Gen. i. 342 (1891). Rosilla.

Paniculately branched, 6 to $15 \mathrm{dm}$. high, the branches ending in long slender peduncles: herbage puberulent: basal leaves oblanceolate, usually sinuate-margined; cauline leaves lanceolate, oblong, or the upper ones linear, entire, sessile and strongly de- 
current on the stem: disk 10 to $15 \mathrm{~mm}$. broad: rays reflexed, short and inconspicuous: disk-flowers red-brown: pappus-paleae ovate, short-awned.

Along streams and in meadows and wet places generally, within the Upper Sonoran Zone: Lower California, Brandegee; Witch Creek, San Diego Co., Alderson, acc. to Parish; Santa Catalina Island, Mrs. Trask; southern base of San Bernardino and San Gabriel Mts.; thence to northern California, where it is abundant near the coast.

2. H. Bigelovii Gray, Pacif. R. Rept. iv. 107 (1857). Heleniastrum Bigelovii Ktze., l. c. Bigelow SNEEzEwEed.

Branching above into several erect peduncle-like branches, 6 to $12 \mathrm{dm}$. high : herbage almost glabrous : leaves lanceolate, thickish, 1 to $2.5 \mathrm{dm}$. long, conspicuously decurrent: rays showy, golden-yellow, 10 to $20 \mathrm{~mm}$. long: disk brownish-yellow : pappuspaleae 5 to 8 , ovate-lanceolate, tapering into a slender awn: achenes hairy.

Stream banks and wet meadows of the Transition Zone in the San Jacinto and San Bernardino Mts.; north to Oregon. Our form differs from typical $H$. Bigelovii in its coarser and thicker foliage which is harsh to the touch. It belongs to what Professor Greene has characterized as Heleniastrum rivulare, ${ }^{51}$ but the other characters assigned to this species-nature of pubescence, pappus, etc.-are inconstant.

\section{BLENNOSPERMA LeSS.}

Low annual herbs with alternate pinnately parted leaves and peduncle-like branches bearing solitary yellow heads. Involucral bracts equal, broadly oblong, united only at the base. Receptacle naked. Heads many-flowered. Ray-flowers fertile; disk-flowers perfect but sterile. Achenes obovate, not compressed or angled, densely covered with minute papillae which swell up and form a mucilaginous covering when moistened. Pappus none.

1. B. Californicum (DC.) T. \& G., Fl. ii. 272 (1842). Coniothele Californica DC., Prodr. v. 531 (1836).

51 Greene, Fl. Fr. 435 (1897). 
Stems branching from near the base, becoming diffuse, about $1 \mathrm{dm}$. high, often naked above: herbage glabrous, slightly succulent: leaves parted into narrowly linear remote lobes: involucre greenish with purple markings: ray-flowers 8 to 11 , the ligule of the corolla 4 to $6 \mathrm{~mm}$. long, or the alternate pistils destitute of corolla; style-branches of ray-flowers broad: disk flowers 20 to 45 , shorter than the involucre, their styles undivided and capitate at summit: achenes obscurely 8 to 10-ribbed.

In moist places; not so common in Southern California as in the middle and northern parts of the state: Cuyamaca, San Diego Co., Orcutt, Brandegee; Wilmington, Los Angeles Co., Lyon, acc. to Parish, also Barber, no. 294; Gardena, McClatchie, ace. to Parish.

\section{NICOLLETIA Gray.}

Perennial very glabrous and somewhat succulent erect herbs of the Desert Area. Leaves narrow, pinnately parted into short linear pungent lobes. Involucre oblong or cylindraceous, either with or without 2 or 3 short outer bracts; its principal bracts 8 to 12 , broadly oblong, acute, dotted with oil-glands and often colored. Style-appendages long, filiform. Achenes attenuate at base, truncate at apex, rusty-pubescent. Pappus of two sorts; the outer of numerous capillary bristles; the inner of 5 lanceolate paleae, the costae of which are continued into scabrous awns.

1. N. occidentalis Gray, Rept. Fremont. 2nd Exped. $516^{\circ}$ (1845).

Stout, erect, 2 to $6 \mathrm{dm}$. high : herbage ill-scented : heads nearly sessile among the upper leaves: involucre about $15 \mathrm{~mm}$. long and two-thirds as broad: rays normally 8 , lurid purple striped with pink, 5 to $7 \mathrm{~mm}$. long.

Lower Sonoran Zone from the northern borders of the Colorado Desert north: first collected by Fremont, ace. to Gray; Twenty-nine Palms, Riverside Co., Brandegee; Mohave Desert, about 1200 m. alt., Parish, no. 3712; Mohave River near Hesperia, Palmer, no. 195, Parish, no. 2403; Daggett, Hall, no. 6149 ; plains near Indian Wells, Kern Co., Purpus, no. 3042, Hall \& Chandler. no. 7365 . 


\section{DYSODIA Cav.}

Ours strong-scented perennial desert herbs with conspicuously striate stems and rather large terminal heads. Herbage either glabrous or minutely pubescent but the involucres blotched with large purple oil-glands. Involuere with an inner series of nearly or quite distinct bracts and an outer series of much shorter calyculate ones. Achenes cylindrical or angled, striate, glabrous in our species. Pappus-paleae about 10, each resolved into numerous capillary divisions.

Leaves spinulose-dentate: involucre 12 to $15 \mathrm{~mm}$. high.

1. D. Cooperi.

Leaves 3 to 5-parted: involucre 10 to $12 \mathrm{~mm}$. high

2. D. porophylloides.

1. D. Cooperi Gray, Proc. Am. Acad. ix. 201 (1874).

Plant 3 to $9 \mathrm{dm}$. high, with numerous erect stems (simple or branched) from a more or less woody base: leaves alternate, 15 $\mathrm{mm}$. or less long, broadly ovate or orbicular to lanceolate, spinulose-dentate: principal bracts of the involucre 20 to 30 , acuminate: rays usually 8 to 12 , orange-yellow (said to turn reddish), $1 \mathrm{~cm}$. long.

From the Mohave and Colorado deserts (Lower Sonoran Zone) east into Arizona: Hesperia to Cushenberry Springs, Parish, nos. 1257, 2392, 3721; Mohave River district, Palmer, no. 194; near Hesperia, May, 1901, Parish \& Greata; near Barstow, Hall, no. 6168 ; Mountain Springs, near the southern boundary of Imperial Co., Parish, no. 2096; Providence Mts. and Warren's Well, Brandegee; near Kingman, Arizona, Jun., 1893, Wilson.

2. D. porophylloides Gray, Mem. Am. Acad. v. 322 (1855).

Size and habit of the last preceding: lower leaves (some opposite or even alternate) petioled, parted into cuneate to lanceolate entire or incised divisions ; upper leaves reduced, entire and linear or simply incised: principal bracts of the involucre 14 to 20 , abruptly acute or mucronate: rays yellow, few and inconspicuous or none.

In the Lower Sonoran Zone from the western borders of the Colorado Desert east into Arizona, south into Mexico: eastern base of San Jacinto Mt., Parish, Hall, no. 2109; San Felipe, Parish; near Dale, San Bernardino Co., Hall, no. 6038. 


\section{POROPHYLLUM Vaill.}

Slender perennial herbs of arid districts; very glabrous but the involucres dotted with oil-glands. Leaves narrowly linear, cntire. Heads solitary, narrow, discoid. Involucre of about 5 broadly oblong equal bracts, with no calyculate outer ones. Styleappendages subulate. Achenes (in our species) attenuate at apex, rusty-pubescent. Pappus of numerous capillary bristles.

\section{P. gracile Benth., Bot. Sulph. 29 (1844).}

Plant 3 to $9 \mathrm{dm}$. high, with numerous very slender branches: leaves few, filiform-linear, 1 to $5 \mathrm{~cm}$. long, entire: involucre 10 to $15 \mathrm{~mm}$. high, naked at base, often purplish-tinged; its bracts oblong, obtuse, bordered with a hyaline margin: corollas dull white and purple.

Common on arid plains and hillsides from near the coast of San Diego Co. across the Colorado Desert to Arizona and Texas; south into Mexico. Also collected in the Cismontane Area (that is, west of the mountains) near Riverside; and on the Mohave Desert at Needles. Herbage strongly and disagreeably scented.

\section{PECTIS L.}

Low branching herbs. Leaves opposite, connate, usually bearing glands containing an essential oil, hence often aromatic. Heads medium-sized or small, mostly radiate, solitary or subcorymbose. Involucre cylindrical or campanulate, of a single series of equal bracts which are inclined to embrace the rayachenes. Style hispidulous, the short branches obtuse and without appendages. Achenes fertile in both disk and ray, terete.

1. P. papposa Harv. \& Gray, Pl. Fendl. 62 (1849) ; Fernald, Proc. Am. Acad. xxxiii. 85 (1897). CHinch-weed.

Plant low, divergently much branched, the branches commonly short, but vigorous specimens often forming mats $4 \mathrm{dm}$. in diameter: leaves opposite, narrowly linear, 1 to $5 \mathrm{~cm}$. long, entire or with a few sharp lobes, bearing 2 to 5 pairs of basal setae: heads $6 \mathrm{~mm}$. high, on peduncles 6 to $20 \mathrm{~mm}$. long: rays 4 to $8 \mathrm{~mm}$. long, yellow: achenes rusty-pubescent: ray-pappus a mere crown, rarely 1 or 2 awns; disk-pappus of 12 to 20 bristles, or sometimes reduced to a crown. 
In the Lower Sonoran Zone from the Mohave and Colorado deserts east to Utah and New Mexico. Common in sandy irrigated places on the Colorado Desert, where known as Chinchweed, because of its strong disagreeable odor, similar to that of the Chinch-bug.

Reported from San Diego, but erroneously so, as pointed out by Mr. Parish. ${ }^{52}$

P. ANGUSTifolia Torr. has a coroniform pappus of 4 or 5 short squamellae and sometimes 2 slender upwardly scabrous awns in addition (the awned form being var. subaristata Gray); heads short-peduncled and more or less fastigiate. Colorado to Lower California and to be expected along our eastern border.

P. FILIPES Gray may be known by the pappus of 1 to 4 rigid upwardly scabrous awns with usually some very short interposed squamellae; heads on elongated capillary peduncles; first reported from "California, Coulter," but many of Coulter's plants labeled as Californian were collected in Arizona.

P. Coulteri Gray has a pappus of 2 to 6 retrorsely barbed awns and a puberulent herbage. Likewise reported from Coulter's "California" collection, but probably restricted to Arizona and Mexico. ${ }^{53}$

P. Linifolia L. (P. punctata Jacq.) has a pappus of 2 or 3 corneous nearly smooth divergent awns. The Synoptical Flora credits it to Southern California by an evident typographical error for Lower California. It occurs in Arizona as the var. marginalis Fernald. ${ }^{54}$

\section{Tribe 8. ANTHEMIDEAE. Mayweed Tribe.}

\section{ANTHEMIS L. Camomile.}

Aromatic branching herbs with alternate never entire leaves. Heads solitary on terminal peduncles. Ray-flowers white or yellow; disk-flowers yellow. Involucre hemispheric. Receptacle conical, chaffy toward the summit. Achenes not flattened, glabrous. Pappus none.

\footnotetext{
52 Zoe v. 120 (1901).

53 Coville, Bot. Gaz. xx. 528 (1895).

54 Proc. Am. Acad. xxxiii. 85 (1897).
} 


\section{A. Cotula L., Sp. Pl. 894 (1753). Mayweed.}

Annual, 2 to $6 \mathrm{dm}$. high, nearly glabrous: leaves mostly sessile, finely and pinnately dissected into linear acute lobes: involucre about $7 \mathrm{~mm}$. broad, shorter than the disk, its bracts imbricated in several series: rays 10 to 20 , white, 8 to $10 \mathrm{~mm}$. long, at length reflexed: chaff of the receptacle narrow and acute or bristle-like: achenes rugose, 10-ribbed.

Pastures and waste ground. Naturalized from Europe.

\section{ACHILLEA L.}

Ours an erect strongly scented perennial herb with finely dissected alternate leaves. Heads radiate, cymose at the ends of the stem and branches. Ray-flowers few, pistillate, fertile. Involucral bracts appressed, imbricated in few series, the outer shorter. Receptacle nearly flat, the chaff membranous and subtending fertile disk-flowers. Achenes linear or oblong to obovate, obcompressed. Pappus none.

1. A. Millefolium L., Sp. Pl. 899 (1753). Сомmon Yarrow. MILFOIL.

Perennial from horizontal rootstocks, the stems simple, 3 to 9 $\mathrm{dm}$. high: herbage glabrate or sparsely villous to lanate-pubescent: leaves linear-lanceolate in outline, the petiole with dilated base, the ultimate segments linear and generally with setaceous callous tips : cyme compound, mostly flat-topped : involucre ovoid, about $5 \mathrm{~mm}$. high: rays 4 to 6 , white or pink, about $3 \mathrm{~mm}$. broad: achenes linear, with a more or less obvious wing or margin.

Widely distributed in Europe, Asia, and North America. In Southern California we have two forms, as follows:

f. Californica (Pollard) Hall, eomb. nov. A. Californica Pollard, Bull. Torr. Club xxvi. 369 (1899). Plant robust, the lower branches of the inflorescence elongated: stems sparsely pubescent, the foliage green and glabrate: tips of the ultimate leafsegments harsh and spinulose: achenes narrowly margined.-The type of A. Californica was "collected by Mr. H. W. Henshaw on the Californian sea coast at Santa Ysabel, May, 1893," acc. to Pollard; Santa Ysabel, at the western base of Cuyamaca Mt., San Diego Co., and about 20 kilometers inland, being probably in- 
tended. The same form comes from San Diego, Palmer, no. 191; from Reche Cañon, near San Bernardino, Parish (who thinks it a waif at this station); and from Laurel Cañon, near Los Angeles, May 12, 1901, Braunton. The only difference I am able to detect between this form and certain European specimens of typical $A$. Millefolium is the slightly more obvious subspinulose tips of the leaf-segments. It is apparently the common east American and European form introduced at a few isolated stations in Southern California and slightly modified by its new environment. Specimens recently distributed from the seaboard of middle California (Heller, no. 6740, etc.) under the name of $A$. Californica, do not belong to this form.

Var. lanulosa (Nutt.) Piper, Fl. Palouse Reg. 196 (1901). A. lanulosa Nutt., Journ. Phila. Acad. vii. 36 (1834). Herbage lanate-pubescent: leaves finely dissected, the segments closely approximate: achenes rather broadly margined.-Very common in the pine belt of all our mountains (San Jacinto Mts., Hall, no. 2507 , etc.) ; also near the coast and on the islands, ranging far north and east of our district. Almost certainly a native in Southern California.

\section{MATRICARIA L.}

Ours glabrous annuals with alternate leaves pinnately dissected into narrowly linear segments. Heads solitary or somewhat eymose, with many greenish-yellow or white flowers. Receptacle mostly slender-conical, naked. Bracts of the involucre imbricated in few series, the outer ones a little shorter than the inner, persistent, scarious-margined. Corollas tuhular and without limb in our species. Pappus reduced to a coroniform border, or none. Achenes glabrous, irregularly nerved.

Heads 5 to $8 \mathrm{~mm}$. high: achenes with an obscure margin at summit.

1. M. matricarioides.

Heads mostly 8 to $14 \mathrm{~mm}$. high: achenes with a broad irregularly lobed crown

2. M. occidentalis.

1. M. matricarioides (Less.) Porter, Mem. 'T'orr. Club v. 341 (1894). Artemisia matricarioides Less., Linnaea vi. 210 (1831). Matricaria discoidea DC., Prodr. vi. 50 (1837). 
Stems leafy, at length much branched, the whole plant 1 to 3 dm. high: herbage glabrous, sweet-scented: heads short-peduncled, 5 to 7 or $8 \mathrm{~mm}$. high: involucral bracts broadly oblong or the outer ones lanceolate, hardly half as long as the greenishyellow ovoid disk: pappus reduced to an obscure border.

Common on low ground. Native of the Old World.

2. M. occidentalis Greene, Bull. Calif. Acad. ii. 150 (1886); K. Brandegee, Zoe ii. 76 (1891).

Two to $6 \mathrm{dm}$. high, the stems either branching or simple below the cymose summit: herbage not so strongly scented as in the preceding : mature heads 8 to 12 or $14 \mathrm{~mm}$. high : achenes sharply angled, crowned by a broad margin which bears two approximate lobes and is thus one-sided.

San Jacinto, 1890, Mrs. Gregory; near San Bernardino (Highlands), Parish, no. 3648 ; middle California.

\section{COTULA L.}

Low herbs with mostly alternate leaves. Flowers yellow. Heads slender-peduncled, discoid, low-hemispheric. Bracts of involucre greenish, nearly equal, in 1 or 2 ranks. Receptacle flat or nearly so, naked. Outer series of flowers pistillate only. Diskflowers with 4-toothed corolla, perfect, fertile or infertile. Mature achenes raised on pedicels, in our species compressed and spongy-margined or narrowly winged. Pappus none.

Annual: leaves pinnately dissected: pistillate flowers in 2 or 3 rows.

1. C. australis.

Perennial: leaves pinnatifid to entire, sheathing at base: pistillate flowers in a single row.

2. C. coronopifolia.

1. C. australis (Sieb.) Hook f., Fl. Nov. Zel. 128 (1853). Anacyclus australis Sieb., in Spreng., Syst. iii. 497 (1825-8).

One-half to $2 \mathrm{dm}$. high, with slender branching stems : herbage not succulent, sparsely pubescent with soft spreading hairs : leaves once or twice pinnately dissected into linear lobes: heads 2 to 5 $\mathrm{mm}$. broad: bracts of the involucre brownish-tipped and with scarious edges : pistillate flowers in 2 or 3 rows, pediceled, apetalous; disk-flowers nearly or quite sessile: marginal achenes some- 
what compressed, minutely hispid on both faces but the margin glabrous.

Occurs sparingly as a waif along the streets of San Diego, Riverside, and Los Angeles. Native of Australia.

2. C. coronopifolia L., Sp. Pl. 892 (1753).

Herbaceous perennial, often subaquatic and then rooting from the lower nodes: herbage somewhat succulent, glabrous: stems commonly many and clustered, decumbent or ascending, 1 to 4 $\mathrm{dm}$. long: leaves linear, lanceolate, or oblong, entire to coarsely toothed or pinnatifid on the same plant, dilated at base into a short sheath around the stem : heads depressed, 8 to $10 \mathrm{~mm}$. broad: pistillate flowers in a single row, their pedicels becoming onehalf as long as the involucre, without corolla; disk-flowers on much shorter pedicels.

Well established along streams and in wet ground. Native of South Africa.

\section{SOLIVA R. \& P.}

Small depressed herbs with petioled and pinnately dissected leaves and small discoid heads of greenish flowers sessile in the forks. Involucre of nearly equal bracts in 1 to 3 series. Receptacle naked. Outer series of flowers pistillate and apetalous; innermost flowers perfect but sterile, the corolla 4-toothed. Achenes obcompressed, pointed with the hardened persistent style, callous-margined or winged, each wing continuing above as a bristle or tooth. Pappus none.

1. S. sessilis R. \& P., Prodr. 113 (1794).

Plant commonly 5 to $10 \mathrm{~cm}$. across, minutely pubescent or rusty-villous: one, two, or three of the heads sessile at the very base, the somewhat tortuous stems radiating from under these: involucral bracts 7 or 8 , oblong, acute, greenish, pilose-pubescent: pistillate flowers 9 to 12 : staminate flowers 7 to 9 : style stout, subulate, conspicuously exserted beyond the disk-corolla: each wing of the achene terminating above in an incurved tooth.

Moist ground near the coast in Santa Barbara Co., ace. to Gray; Arroyo Grande, San Luis Obispo Co., Miss King. Probably introduced from Chile. 


\section{ARTEMISIA L. WORMWOOD.}

Herbs or shrubby plants, mostly bitter and aromatic, with alternate leaves. Heads small, discoid, nodding or erect, in panicled spikes or racemes. Flowers yellow or purplish, all tubular; disk-flowers perfect and marginal ones pistillate, or all perfect. Corolla of the pistillate flowers 2 or 3-toothed, of the perfect flowers 5-toothed. Involucre imbricated, dry and scarious. Receptacle nearly flat to hemispheric, naked in all our species except the last. Achenes obovoid or oblong, glabrous (except in A. Parishii), with a small terminal areola. Pappus none.

Flowers of the margin pistillate; central flowers perfect (their achenes abortive and sterile in no. 1).

Herbage glabrous.

Leaves linear, mostly entire. 2. A. dracunculoides.

Leaves serrulate to bipinnatifid 4. A. biennis.

Herbage (at least the lower surface of the leaves) tomentose.

Branches spinescent: flowers cobwebby with erisped hairs.

1. A. spinescens.

Branches not spinescent: flowers resinous.

Shrubby: leaves or their segments linear-filiform

3. A. Californica.

Herbaceous (except at base in some): leaves or their segments broader.

Leaves white-tomentose on both sides

5. A. Ludoviciana.

Leaves green and early glabrate above

6. A. heterophylla.

Flowers all perfect and fertile: shrubs.

Receptacle naked: leaves white-tomentose or canescent on both sides.

Achenes glabrous.

Accessory bracts of the involucre short and ovate: leaves 3toothed to entire

7. A. tridentata.

Accessory bracts of the involucre oblong or lanceolate: leaves 3-cleft or -parted to entire 8. A. trifida.

Achenes arachnoid with long hairs: leaves mostly entire.

9. A. Parishii.

Receptacle chaffy, most of the flowers being subtended by scale-like bracts: leaves green above. 10. A. Palmeri.

1. A. spinescens Eat., Bot. King Exped. 180, t. 19, ff. 15 to 21 (1871). Picrothamnus desertorum Nutt., Trans. Am. Philos. Soc. ser. 2, vii. 417 (1841); not Artemisia desertorum Spreng. (1825-8). 
Stems woody, intricately branched, 1 to $5 \mathrm{dm}$. high, the persistent branches becoming stout spines : herbage white-tomentose, especially the young branchlets: leaves about .5 to $.7 \mathrm{~cm}$. long including the petiole, pedately 5-parted and the divisions 3-lobed, the lobes spatulate: heads in short lateral spikes: involucre globose, $3 \mathrm{~mm}$. in diameter; bracts 5 or 6 , obovate, obtuse: flowers 5 to 12 , both corolla and achene loosely arachnoid with long crisped hairs.

Southern part of the Mohave Desert (Rabbit Springs, Hesperia, Lancaster, etc.), north and east to Oregon and Wyoming. Plentiful in sandy soil from Owens Valley to the Panamint Mts. Flowering period earlier than of other Artemisias and the habit different, but plainly congeneric with them.

\section{A. dracunculoides Pursh, Fl. ii. 742 (1814).}

Six to 12 or $15 \mathrm{dm}$. high: stems not woody, either virgately or paniculately branched above: herbage glabrous, strongscented: leaves linear, 2 to $10 \mathrm{~cm}$. long, 2 to $4 \mathrm{~mm}$. wide, entire or the lowermost 3-toothed or -cleft: heads numerous, on very slender short peduncles in a close or open panicle, the clusters sometimes secund on the slender branches: involucre nearly hemispheric, 2 or $3 \mathrm{~mm}$. high : receptacle hemispheric.

Common throughout western North America; with us ranging from the seashore to $2500 \mathrm{~m}$. alt. in the mountains, and from National City, San Diego Co., north.

3. A. Californica Less., Linnaea vi. 523 (1831). Hill-BRUSH.

Gray shrub, 6 to $12 \mathrm{dm}$. high: herbage aromatic, clothed with a minute appressed pubescence, varying to green and nearly glabrous: leaves once or twice parted into linear-filiform segments, or the upper ones entire and more or less fascicled: heads many, in long racemose panicles, nodding: involucre hemispheric, 2 or $3 \mathrm{~mm}$. high : achenes with a minute squamellate crown.

Common on hills of the Upper Sonoran Zone from Lower California (Guadalupe Island, Franceschi, no. 11) north to San Francisco Bay; most plentiful toward the coast (including Santa Catalina Island) but ranges as far inland as the borders of the desert in San Gorgonio Pass (Cabazon, Schellenger, no. 44). Specimens from the islands have broader and thicker leaves with 
less numerous and shorter lobes, and more scattered heads of larger size. A form intermediate betwen this and the mainland form comes from the Coronados Islands.

4. A. biennis Willd., Phytogr. 11, no. 39 (1794).

Erect, 4 to $8 \mathrm{dm}$. high, from an annual or biennial root: herbage glabrous, inodorous : leaves 3 to 8 or the lower even $12 \mathrm{~cm}$. long, bipinnately divided into lanceolate or broadly linear incised or serrulate divisions, or the uppermost only pinnatifid to nearly entire: heads erect, sessile, crowded on the short branchlets, forming a spike-like inflorescence, which is more or less leafy : involucre hemispheric, about $2 \mathrm{~mm}$. high: achenes with a small epigynous disk.

Sparingly introduced on low moist ground near Los Angeles and Santa Ana; to be expected elsewhere. Native of northwestern America.

5. A. Ludoviciana Nutt., Gen. ii. 143 (1818).

Three to $10 \mathrm{dm}$. high : stems scarcely woody below, from running rootstocks, simple and erect, or with few virgate branches: herbage whitened throughout with a lanate tomentum or the upper surface of the leaves rarely somewhat glabrate: lower leaves 4 to $6 \mathrm{~cm}$. long, narrowly to broadly lanceolate, somewhat cilated above and coarsely toothed, cleft, or parted into entire acute lobes: upper leaves becoming narrow and entire, acute: heads erect or horizontal, the dense spikes in a narrow compact panicle the lower part of which is leafy-bracteate: involucre hemispheric, 15 to 25 -flowered, 3 to $4.5 \mathrm{~mm}$. high.

Western North America; not common in our district: San Bernardino Mts. at Bear Valley, etc., Blasdale, Parish, no. 1456, Abrams, no. 2823, Grant, no. 6367; Santa Rosa Mts., Mrs. Trask, nos. 85, 112, 138; Providence Mts., Brandegee (herbage only).

In case $A$. Ludoviciana Nutt., and $A$. gnaphalioides Nutt. ${ }^{55}$ are considered not distinct then, by the rule of priority of position, the latter name has precedence.

6. A. heterophylla Nutt., Trans. Am. Philos. Soc. ser. 2, vii. 400 (1841). A. Kennedyi A. Nelson, Proc. Biol. Soc. Wash. xviii.

55 Nuttall, l.c. 


\section{5 (1905). Not A. heterophylla Besser (1834). CaLifornia} MUGWORT.

Stems erect, woody at base, strict, 6 to $16 \mathrm{dm}$. high : leaves 4 to $10 \mathrm{~cm}$. long, lanceolate to broadly oblong or elliptic, sparingly pinnatifid (with downward incisions), cleft, or often entire (especially the upper), green above, white-tomentose beneath: heads mostly erect, the spikes in an open or more commonly dense terminal panicle, the main axis leafy below and bracteate above: involucre ovoid, 12 to 25 -flowered, 3 or $4 \mathrm{~mm}$. high, permanently arachnoid.

Common on wet ground toward the coast, less plentiful in the mountains up to $1500 \mathrm{~m}$. alt. (Upper Sonoran Zone), from Orange Co. to Washington and the Rocky Mts. : San Jacinto Mt., Hall, no. 2633; Verdugo Cañon, near Los Angeles, Chandler, no. 2051; etc.

From Nuttall's $A$. heterophylla have been segregated two distinct species: A. Suksdorfii Piper, ${ }^{56}$ and A. Kennedyi A. Nelson. Although I have not seen the type of $A$. heterophylla Nutt., I judge it to be identical with $A$. Kennedyi, since Nuttall had only specimens from the Rocky Mountains. A. heterophylla Besser being an unsustained spécies, our plant takes the name A. heterophylla Nutt., in accordance with Art. 50 of the Vienna rules.

It has been assumed that this is not a seacoast species, but besides occurring on the seacoast of Southern California, as noted above, it is plentiful along the seaboard of middle California, whence came three specimens cited by Professor Nelson, viz., Heller, no. 7195, from Pacific Grove, which is as near the Pacific as it could well be, Michener \& Bioletti's plant from Temescal Lake, which is within 4 kilometers of San Francisco Bay, and Heller, no. 7209, from Los Gatos, also near the coast. However, A. Suksdorfii and A. heterophylla (A. Kennedyi) do belong to distinct geographic areas; the former to a narrow, humid coast belt from British Columbia to Humboldt Co., California, the latter to the interior districts from Washington to Southern California and the seaboard from San Francisco Bay south. This distribution is not surprising when we consider that numerous

56 Bull. Torr. Club xxviii. 42 (1901). 
other species of the northwest coast extend south to middle California, while many forms belonging to the interior of our northern states reach the seacoast only in Southern California.

7. A. tridentata Nutt., Trans. Am. Philos. Soc. ser. 2, vii. 398 (1841). Sagebrush.

Commonly an erect much branched shrub with a distinct trunk and shreddy bark: herbage aromatic, eanescent or silvery throughout with a fine and close tomentum: leaves mostly 1.5 to $3.5 \mathrm{~cm}$. long, narrowly cuneate, the truncate summit with 3 or 4 obtuse teeth or lobes, the uppermost ones linear and entire: panicles diffuse, commonly $3 \mathrm{dm}$. or more long: involucre narrow, 5 to 8-flowered, about $4 \mathrm{~mm}$. high; accessory bracts short, ovate.

This, the true Sagebrush, ranges from Lower California north along the desert ranges to the high plains of the Great Basin and extends even into Washington and Montana. It is by far the most abundant and best-known shrub in this whole region, in many places forming the principal vegetation of thousands of acres. In Southern California the Sagebrush is abundant on the lower slopes of mountains facing the Colorado and Mohave deserts, where it occupies the Upper Sonoran Zone and often extends into the Lower Transition. West of the mountains it has been found at the following stations: Descanso, San Diego Co. Mrs. Brandegee; Fallbrook, San Diego Co., Parish; Colton and San Bernardino, Parish; near Riverside Reed, no. 832; and between Glendale and Burbank, near Los Angeles Braunton, no. 907.

Var. angustifolia Gray, Proc. Am. Acad. xix. 49 (1883). Leaves all narrower, the lower barely 3-toothed, the upper entire and less than $2 \mathrm{~mm}$. wide.-Idaho and the Mohave Desert to southern San Diego Co., acc. to Gray.

8. A. trifida Nutt., Trans. Am. Philos. Soc. ser. 2, vii. 398 (1841). A. tripartita Rydb., Mem. N.Y. Bot. Gard. i. 432 (1900).

A much branched shrub, 2 or 3 to rarely $6 \mathrm{dm}$. high : herbage silvery or canescent with a very fine close tomentum : leaves about $1 \mathrm{~cm}$. long, linear except the dilated upper portion which is cleft or parted into 3 linear lobes; upper leaves entire: inflorescence contracted, sometimes of simple spikes only a few $\mathrm{cm}$. long ter- 
minating the slender stems: involucre cylindric, 3 to 9 -flowered, nearly $5 \mathrm{~mm}$. high, the accessory bracts oblong or lanceolate.

Near Lancaster, Mohave Desert, Parish, no. 1177 (identical with Nuttall's plants, acc. to note by Gray in Herb. Parish). More common in the Sierra Nevada Mts., Utah, ete.

9. A. Parishii Gray, Proc. Am. Acad. xvii. 220 (1885).

Plant distinctly shrubby, 6 to $9 \mathrm{dm}$. high: herbage densely and closely cinereous-pubescent: leaves 2 to $4 \mathrm{~cm}$. long, linearspatulate, strongly 1-nerved, mostly entire but some of the lower ones 2 or 3 -toothed at apex, the margins revolute: heads inclined to nod when mature, in small close glomerules which are scattered on short branchlets of the rather loose oblong panicle: involucre oblong, 5 to 7 -flowered, 3 or $4 \mathrm{~mm}$. long: achenes arachnoid-villous.

Newhall, Los Angeles Co., Nov., 1881, Parish, no. 1065 (duplicate type); Mohave Desert, Oct. 19, 1882, Pringle; Rosamond, in the creosote belt of Antelope Valley, Los Angeles Co., Oct., 1896, Davy, no. 2933; all in the Lower Sonoran Zone. The report that this species was collected at Cajon Pass is erroneous, ace. to Parish. $^{57}$

\section{A. Palmeri Gray, Proc. Am. Acad. xi. 79 (1876).}

Stems herbaceous or somewhat woody, slender and erect, tall, minutely pubescent: leaves (about $5 \mathrm{~cm}$. long) almost glabrous above, densely cottony-tomentose beneath, linear and entire or mostly with few linear lobes, the margins closely revolute: heads mostly nodding when mature, either glomerate or somewhat lcosely disposed on the branches of the elongated panicle: involucre hemispheric, $3.5 \mathrm{~mm}$. high : receptacle chaffy, its searious bracts subtending at least many of the flowers.

From the vicinity of San Diego to Lower California: Jamul Valley, Palmer, Miss Bird, acc. to Gray; near National City, Purpus, Brandegee, etc.

57 Zoe v. 120 (1901). 
Tribe 9. SENECIONEAE. Groundsel Tribe.

89. RAILLARDELLA Gray.

Ours a low seapose perennial of the Alpine Zone, with entire silvery-tomentose leaves and solitary heads. Involucral bracts barely overlapping. Receptacle flat. Heads discoid in our species. Disk-corollas with short tube, elongated throat, and 5 short naked teeth. Style-appendages flattish, with lanceolate or cuspidate tips. Achenes linear, pubescent. Pappus of 12 to 25 slender soft-plumose bristles.

1. R. argentea Gray, Bot. Calif. i. 417 (1876). Raillardia argentea Gray, Proc. Am. Acad. vi. 550 (1865).

Scapes 1 to $10 \mathrm{~cm}$. high, from creeping rootstocks: leaves crowded in a basal tuft and on short sterile shoots, linear-spatulate to oblanceolate, acute, from less than $1 \mathrm{~cm}$. to 4 or $5 \mathrm{~cm}$. long: involucre narrowly campanulate, 8 to $10 \mathrm{~mm}$. high, its bracts acuminate: flowers yellow.

Known to occur in Southern California only on the summit of Mt. San Gorgonio (Grayback), where a depauperate form is common in gravelly soil above timber line: plentiful in the high Sierra Nevadas.

\section{LEPIDOSPARTUM Gray.}

Ours a rigid broom-like shrub with alternate leaves, all but the earliest of which are reduced to scales. Bracts of the involucre regularly imbricated in 3 or 4 series, chartaceous, oblong, obtuse. Receptacle naked. Heads discoid. Corolla with long tube; the short campanulate throat exceeded by the spreading lobes. Anthers exserted, sagittate at base, the tips lanceolate. Stylebranches flattish, with acute tips. Achenes terete, faintly 8 to 10-nerved. Pappus of numerous minutely scabrous capillary bristles.

1. L. squamatum Gray, Proc. Am. Acad. xix. 50 (1883). Linosyris squamata and var. Breweri Gray, l. c. viii. 290 (1870). Tetradymia squamata Gray, Bot. Calif. i. 408 (1876).

A round-topped bush, 1 to $2 \mathrm{~m}$. high, with ascending virgate branches: very young plants tomentose and leafy with spatulate 
entire leaves $1 \mathrm{~cm}$. or so long, but the tomentum early deciduous and all the later leaves reduced to ovate-acute scales $(1 \mathrm{~mm}$. or less long) of the green branches: heads solitary terminating the short lateral branchlets and thus appearing as if racemose or spicate, the uppermost nearly or quite sessile and thus glomerate: involucre campanulate, 5 to $8 \mathrm{~mm}$. high: achenes glabrous.

Common in sand-washes and in dry gravelly soil of the Sonoran zones, from San Luis Obispo Co. to Lower California and east to Arizona. Also near Exeter, Tulare Co., in the San Joaquin Valley, Jul. 23, 1905, Mrs. Brandegee.

\section{ARNICA L.}

Erect perennial herbs of temperate and arctic regions. Leaves all opposite or the upper alternate. Heads large, yellowflowered, mostly several and long-peduncled at the summit of the single stem. Involucre broadly campanulate, not calyculate at base; bracts equal. Receptacle flat, naked to fimbrillate or villous. Disk-flowers many, yellow; ray-flowers pistillate when present, yellow. Style-branches with flattish tips acute or obtuse. Achenes slender, somewhat 5 to 10-costate or angled. Pappus a single row of rather rigid and strongly roughened denticulate white bristles.

Lower leaves cordate or ovate, obtuse

1. A. cordifolia.

Lower leaves elliptic-lanceolate, acute. 2. A. Bernardina.

1. A. cordifolia Hook., Fl. Bor. Am. i. 331 (1834).

Stems 3 to $6 \mathrm{dm}$. high, from creeping rootstocks: herbage pubescent, the stems and peduncles commonly hirsute or villous: lower leaves long-petioled, deeply cordate to ovate, obtuse, dentate; upper leaves small, sessile: heads either solitary and terminating the simple stem or several and long-peduncled in a loose cyme : involucre about $15 \mathrm{~mm}$. high : rays about 2.5 to $3 \mathrm{~cm}$. long: achenes somewhat hirsute.

Lower Transition Zone on Cuyamaca Mt., San Diego Co., Aug., 1898, Dunn; Sierra Nevadas to British Columbia and Colorado.

2. A. Bernardina Greene, Pitt. iv. 170 (1900).

Stems 2.5 to $5 \mathrm{dm}$. high, from a cluster of thick roots : herbage cinereous with a fine tomentose pubescence, this overspread (often 
copiously) with long arachnoid hairs, at least the stems glabrate in age : leaves elliptic-lanceolate, acute, the upper partly clasping by a narrowish base, the lower with the tapering bases connate in pairs, sparingly denticulate or entire, the largest $12 \mathrm{~cm}$. long and $2 \mathrm{~cm}$. broad: heads peduncled, 2 or 3 in a terminal cluster or solitary: involucre 8 or $9 \mathrm{~mm}$. high; its oblong bracts comose at the obtuse or merely acutish apex : rays about $1.5 \mathrm{~cm}$. long : diskflowers conspicuously exceeding the involucre: achenes sparsely short-setulose.

Meadows of the Upper Transition and Canadian zones, at 2000 to 2750 m. alt., San Bernardino Mts.: Bear Valley, Parish, no. 3719; Bluff Lake, Jul., 1889, Hall, also Grinnell, no. 82 ; Dry Lake, on north side San Gorgonio Mt. (Grayback), Mrs. Wilder, no. 599 .

\section{PEUCEPHYLLUM Gray.}

Desert shrub with crowded terete resinous-punctate leaves. Heads discoid. Involucre campanulate, foliaceous. Receptacle naked, flat. Flowers yellowish: corolla with very short proper tube and long cylindric throat; teeth short, ovate, obtuse, erect, puberulent. Style-branches linear, semi-terete; the tip broad, obtuse and destitute of appendage. Anthers with oval obtuse tips. Achenes turbinate-oblong, very hirsute. Pappus shorter than the corolla, of numerous unequal rather sordid and roughish bristles, the longer of these sometimes toothed or with hyaline toothed margins or not infrequently flattened and passing into linear hyaline paleae!

The affinities of this peculiar genus are not known. It was once placed in the Eupatorieae, but its yellow corollas and flat style-branches seem to indicate a different relationship. Mr. M. E. Jones ${ }^{58}$ would place it near Dysodia and it may belong somewhere in the Helenieae, but scarcely in Tagetineae, the nature of the oil-glands, the involucre, and the habit being very different. Mr. Jones was the first to point out the sometimes paleaceous nature of the pappus and this character is certainly suggestive of a Helenioid origin, but certain species of Ligularia (Senecillus), which is always accepted as Senecioid, has short flattened almost 
paleaceous toothed bristles. The style-branches, moreover, are more like those of Luina, than of. any genus in the Helenieae, while in corolla and some other characters it resembles Psathyrotes. Since its affinities are so doubtful I here follow Bentham ${ }^{59}$ in placing Peucephyllum in the Senecioneae, at least provisionally.

1. P. Schottii Gray, Bot. Mex. Bound. 74 (1859); Jones, Zoe v. 41 (1900). Psathyrotes Schottii Gray, Proc. Am. Acad. ix. 206 (1874). Inyonia dysodioides M. E. Jones, Contr. W. Bot. viii. 42 (1898).

Sometimes only $3 \mathrm{dm}$. or so high and spreading, more often 1 to $3 \mathrm{~m}$. high and with a trunk-like stem: bark rough: leaves green, crowded on the ultimate branchlets, 5 to 20 or even $30 \mathrm{~cm}$. long, punctate and exuding a balsamic resin: heads scattered, nearly sessile and hidden by the upper leaves: involucre nearly $1 \mathrm{~cm}$. high; bracts green, linear-subulate.

In eañons and on foothills of the Lower Sonoran Zone from Inyo Co. to Lower California and Arizona: Panamint eañon, Inyo Co., M. E. Jones; Ord Mts.; Warrens; Whitewater; Morongo Pass; Thousand Palms; hills near Coachella; Indio Mts.; Palm Springs; Cañon Springs Wash; Split Mt.; Calamujuet, on the coast of Lower California, May 11, 1889, Brandegee.

\section{PSATHYROTES Gray.}

Low winter annuals (and biennials?) of the Desert Area. Herbage scurfy or tomentose. Leaves alternate, petioled, broad and rounded. Heads discoid. Involucre broadly hemispheric. Receptacle flat, naked. Corolla with very short proper tube, elongated cylindric throat, and short teeth which are more or less woolly or glandular. Style-branches flattish, obtuse. Achenes turbinate, villous. Pappus of numerous short scabrous bristles, varying from white to ferruginous in the same species.

Outer involucral bracts much broader than the inner, the obtuse tips spreading or recurved: leaves thick. 1. P. ramosissima.

Outer involucral bracts not very different from the inner, all with erect tips: leaves thinner 2. P. annua.

59 Bentham, in Bentham and Hooker, Gen. Pl. ii. 438 (1873). 
1. P. ramosissima (Torr.) Gray, Proc. Am. Acad. vii. 363 (1868). Tetradymia ramosissima Torr., in Emory Rept. 145 (1848).

Stem suffrutescent at base and persistent for at least one year: much branched and densely leafy forming a compact rounded plant $15 \mathrm{~cm}$. or less high and 5 to $20 \mathrm{~cm}$. across : herbage white with a dense close tomentum, strongly scented with a turpentine-like odor: leaves thick, coarsely and irregularly toothed, subcordate or tapering into the stout petiole: peduncles either short and erect or longer and recurved, so that the heads always remain embedded in the dense foliage: involucre 6 or $7 \mathrm{~mm}$. high ; outer bracts broadly oblong, obtuse, the broad tips somewhat spreading or recurved; inner bracts narrower, sometimes acutish: corollas yellow or purplish: achenes short-turbinate.

Lower Sonoran Zone: Borregos Springs, Colorado Desert: Brandegee; near Palm Springs, Colorado Desert, Schellenger, no. 40 ; Sheephole Mts., Mohave Desert, Hall \& Chandler, no. 6071; Panamint Valley, Inyo Co.; east into Arizona, south into Lower California. Very common on ledges of rocks and in stony soil on the Colorado Desert of eastern Riverside and Imperial counties.

2. P. annua (Nutt.) Gray, Pl. Wright. ii. 100 (1853). Bulbostylis annua Nutt., Journ. Phila. Acad. n. ser. i. 179 (1848).

Root strictly annual: stem loosely branched, the branches ascending, 5 to $15 \mathrm{~cm}$. high : herbage with a scurfy tomentum: leaves short-cuneate at base, coarsely and irregularly dentate, the small often entire ones of the inflorescence carried beyond the heads by their petioles: peduncles very short, commonly reflexed in age: involucre 7 to $9 \mathrm{~mm}$. high; bracts ovate-oblong to linearlanceolate, usually acute, all erect and the outer ones not larger than the inner: corollas pale yellow or purplish: achenes oblongturbinate: pappus less copious than in no. 1 .

Lower Sonoran Zone: alkaline soil near Rabbit Springs, southern Mohave Desert, Parish, no. 1260; Red-rock Cañon, eastern Kern Co., Hall \& Chandler, no. 7375; Owens Valley; east to Utah and Arizona. 


\section{TETRADYMIA DC.}

Low rigid shrubs of arid districts. Herbage clothed with dense and matted or floceose wool which is deciduous in some species. Leaves alternate, entire, solitary or fascicled, the primary ones often modified into spines. Involucre eylindric to oblong, composed of 4 to 6 firm concave overlapping bracts which are often enlarged and thickened at base. Heads discoid, 4 to 9flowered. Receptacle flat, small. Corollas yellow; lobes spreading, longer than the short-campanulate throat, much shorter than the elongated tube. Anthers exserted, sagittate at base, the tips triangular-lanceolate. Style-branches flat, obtuse. Achenes terete, faintly 5-nerved. Pappus of fine and soft scabrous capillary bristles, white or whitish.

Pappus copious, much exceeding the hairs of the achene, or the achenes glabrous.

Heads 4-flowered: leaves not spiny.

Leaves linear to oblanceolate, 1 to $2 \mathrm{~cm}$. long, not glabrate

1. T. canescens.

Leaves linear to subulate, less than $1 \mathrm{~cm}$. long, glabrate.

2. T. glabrata.

Heads 5-flowered: upper leaves rigid, spiny.

..3. T. stenolepis.

Pappus-bristles in a single series, searcely exceeding the long ascending hairs of the achene.

Heads pedunculate, scattered or loosely racemose

4. T. spinosa.

Heads nearly sessile in a close terminal cyme.

.5. T. comosa.

1. T. canescens DC., Prodr. v. 440 (1837).

Stems 1 to $3 \mathrm{dm}$. high, freely branching: foliage and inflorescence white with a permanent close tomentum : leaves somewhat crowded but rarely at all fascicled, linear or linear-lanceolate, pungently acute, mostly 1 to $2 \mathrm{~cm}$. long: heads short-pedunculate in cymose clusters terminating the short branchlets: involucre 8 to $10 \mathrm{~mm}$. high, 4 -flowered; bracts 4 or 5 , strongly carinate, oblong: achenes varying from glabrous to villous: pappus copious, sordid or yellowish.

Upper Sonoran and Transition zones below $2300 \mathrm{~m}$. alt: San Bernardino Mts. (Barton Flat, South Fork, Bear Valley, Doble), San Antonio Mts. (Rock Creek), Sierra Nevada and Rocky Mts.Also (in the var. inermis (Nutt) Gray, with shorter leaves and 
involueres) in the Coast Ranges near San Luis Obispo (Palmer, no. 261).

2. T. glabrata Gray, Pacif. R. Rept. 11.pt. 2, 122, t. 5 (1855).

Stems branching to form rounded bushy plants $1 \mathrm{~m}$. or less high: leaves early glabrate, mostly 5 to $10 \mathrm{~mm}$. long, 3 to 6 in each fascicle; the primary ones rigid-subulate, cuspidate, mostly 5 to $10 \mathrm{~mm}$. long, early deciduous; axillary fascicled leaves soft and pointless, persistent; leaves of sterile shoots linear-subulate, appressed, without fascicled ones in their axils : heads in terminal cymes or the cymose clusters sometimes racemosely disposed: involucre 7 or $8 \mathrm{~mm}$. high, white-tomentose or glabrate and green, 4 -flowered; bracts 4 or 5, oblong, carinate: achenes densely villous : pappus copious, sordid.

Lower and Upper Sonoran zones from the Mohave Desert to Oregon and Utah: Rabbit Springs, Parish; Lancaster, Davidson; Owens Valley, where common on low hills.

3. T. stenolepis Greene, Bull. Calif. Acad. i. 92 (1885).

Stems about 6 or $8 \mathrm{dm}$. high, corymbosely much branched: herbage permanently white-tomentose with appressed wool : lower primary leaves oblanceolate, tipped with a sharp mucro, about $2 \mathrm{~cm}$. long; upper (and often all) primary leaves modified into rigid spreading spines 2 to $3 \mathrm{~cm}$. long; secondary fascicled leaves oblanceolate and $1 \mathrm{~cm}$. or less long, or entirely wanting: heads in close terminal cymes: involucre 10 to $12 \mathrm{~mm}$. high, 5 -flowered; bracts 5, oblong, very thick and rigid, obtuse: achenes canescent but glabrate: pappus comparatively coarse.

Lower Sonoran Zone of the Desert Area from Antelope Valley, Los Angeles Co., to Inyo Co. : Hesperia, San Bernardino Co., Sept., 1907, Edw. Hoykendorf; Fairmount, Los Angeles Co., Hall, no. 6712 ; Kernville, Purpus, no. 5651; Argus Mts., Purpus, no. 5463; Cottonwood Ranch, Inyo Co., Brandegee. Acc. to Mrs. Brandegee the type specimens were gathered a short distance southwest of the Southern Pacific railroad between Cameron and Mohave stations.

4. T. spinosa H. \& A., Bot. Beech. 360 (1840).

A rigidly branched shrub 6 to $12 \mathrm{dm}$. high: stems densely white-tomentose : primary leaves modified into rigid spines which 
may be either straight or recurved, 1 to $4 \mathrm{~cm}$. long, tomentose or glabrate; secondary fascicled leaves commonly present, small, linear-clavate, glabrous or early glabrate: heads on stout peduncles arising from the leaf-axils : involucre about $8 \mathrm{~mm}$. high, usually 6 or 7 -flowered; bracts 5 or 6 , the outer ones oblong, the inner ones from broadly oblong to nearly orbicular, all obtuse: achenes with soft white wool nearly equalling the rigid pappusbristles.

The most common species of the Desert Area; characteristic of the upper portion of the Lower Sonoran Zone, acc. to Coville: Warren's Well, at the eastern end of the San Bernardino Mts., Brandegee; thence to Oregon, Utah, Arizona, etc.

5. T. comosa Gray, Proc. Am. Acad. xii. 60 (1876).

Stems with many virgate branches forming an erect bush 6 to $12 \mathrm{dm}$. high : herbage permanently and densely white-tomentose: earlier primary leaves soft, linear, 2.5 to $5 \mathrm{~cm}$. or more long; the later ones narrower, rigid and more or less spine-like; fascicled secondary leaves like those of $T$. spinosa, or usually absent: heads in close terminal cymes: involucre 8 to $10 \mathrm{~mm}$. high, 6 to 9 flowered; bracts 5 or 6 , oblong, obtuse: long soft wool of the achene concealing the true pappus.

Scattered throughout the warmer and drier parts of the Sonoran zones west of the mountains, from Los Angeles Co. to San Diego Co.: Newhall, acc. to Davidson; Pasadena, ace. to MeClatchie; Pomona; West Riverside; San Bernardino; Temecula Creek; Palomar; Buckmans Springs; Campo; San Diego. Also at Lancaster and Hesperia, in the Lower Sonoran Zone of the Mohave Desert, acc. to Parish; and in Nevada, ace. to Gray.

\section{SENECIO L. GroundSEL.}

Herbs or woody plants with alternate leaves and with heads in terminal cymes or rarely solitary. Heads many-flowered, radiate or discoid. Flowers in our species yellow. Involucre cylindrical to campanulate, mostly with 1 or 2 rows of outer erect bracteoles at base, these elongated and exceeding the proper involucre in a few non-Californian species. Receptacle flat, naked. Anthers mostly rounded at base. Style-branches truncate. Achenes terete. Pappus of abundant white and soft bristles. 


\section{A.-Perennial herbs and suffrutescent plants.}

Stems herbaceous: lower leaves either undivided or with broad and rounded lobes.

Leaves from entire to serrate or pinnatifid.

Heads discoid: leaves ample

1. S. astephanus.

Heads radiate.

Plant leafy up to the inflorescenc: leaves acute.

Blade of leaf triangular-lanceolate, 2 to $5 \mathrm{~cm}$. wide

2. S. triangularis.

Blade of leaf linear, 1 to $3 \mathrm{~mm}$. wide: var. sanctus of

3. S. serra.

Plant nearly leafless above the middle, 2 to $4 \mathrm{dm}$. high: leaves obtuse

4. S. ionophyllus.

Leaves mostly pinnately divided or parted and again lobed or incised

5. S. eurycephalus.

Stems suffrutescent at base: leaves pinnately parted into linear lobes (except the upper ones).

Leaf-lobes acute: involucre copiously bracteolate

6. S. Douglasii.

Leaf-lobes obtuse: involucre sparingly bracteolate: insular species

7. S. Lyoni.

\section{B.-Annuals.}

Rays conspicuous.

8. S. Californirus.

Rays wanting or very inconspicuous.

Indigenous desert annual: leaves ample

9. S. Mohavensis.

Naturalized weeds.

Involucral bracts with green or pale tips: rays present, minute

10. S. sylvaticus.

Involucral bracts black-tipped: rays none

11. S. vulgaris.

1. S. astephanus Greene, Pitt. i. 174 (1888). S. ilicetorum Davidson, Eryth. ii. 85 (1894).

Stout, erect, 4 to $10 \mathrm{dm}$. high, from a perennial root, leafy: herbage floccose-woolly, the upper surface of the leaves and the inflorescence glabrate: leaves thin, elliptic or oblanceolate, acute, remotely dentate with small spreading callous-tipped teeth; lower leaves 2 to $3 \mathrm{dm}$. long including the petiole, 3 to $5 \mathrm{~cm}$. wide; upper leaves smaller, tapering to a sessile base, some entire: heads 6 to 12 , nearly sessile in a compact terminal cyme: involucre 8 $\mathrm{mm}$. high; bracts numerous, linear-lanceolate, acute, some of the outer ones reduced and calyculate: rays none: achenes 10-nerved, glabrous.

Mountains of San Luis Obispo Co., 1887, Mr. and Mrs. Lemmon, ace. to Greene; Upper Sonoran Zone, on the trail to Wilsons Peak, San Gabriel Mts., Davidson. 
2. S. triangularis Hook., Fl. Bor. Am. i. 332, t. 115 (1834). S. trigonophyllus Greene, Pitt. iii. 106 (1896).

Erect, 1 or $2 \mathrm{~m}$. high, simple and leafy up to the loose terminal cyme: herbage glabrous : leaves thin (usually drying black under pressure), triangular-lanceolate, acute, 1 to $1.5 \mathrm{dm}$. long, 2 to 5 $\mathrm{cm}$. broad at the truncate or cordate base, short-petiolate, shallowly sinuate-dentate or sometimes with salient sharp teeth; uppermost leaves smaller, narrow, with tapering base, some of them entire: involucre narrowly campanulate, $6 \mathrm{~mm}$. high, with several calyculate bracts at base : rays 6 to 12, deep yellow, 5 to 8 mm. long.

Along streams and in bogs of the Canadian and Hudsonian zones: San Jacinto Mts. at 2400 to 2800 m. alt.; San Bernardino Mts. at Bluff Lake, 2200 m. alt., and on South Fork of the Santa Ana River at $2500 \mathrm{~m}$. alt.; more common in the Sierra Nevadas and Rocky Mts., extending north to Saskatchewan. Stems commonly several or numerous in a close clump, carrying their rather showy clusters of heads above other herbaceous vegetation. Jul.Sept.

\section{S. serra sanctus Hall, var. nov.}

Root perennial, woody, perpendicular: stems several, herbaceous, erect, very leafy up to the flowering branches, the whole plant 2 to $3.5 \mathrm{dm}$. high : herbage completely glabrous except the inflorescence which bears a minute and sparse tomentum: leaves ascending or spreading or even deflexed, often curved, linear, all entire, acute, 4 to $7 \mathrm{~cm}$. long, 1 to $3 \mathrm{~mm}$. wide: heads numerous in a loose terminal leafy-bracted cyme: involucre nearly cylindric but slightly narrowed downward, $7 \mathrm{~mm}$. high; bracts 8 or 9 , linear, with acute pubescent tips, green, the margins scarious; outer calyculate bracts few or none: rays 5 , yellow, about $5 \mathrm{~mm}$. long: disk-flowers 10 to 12 : achenes glabrous.

Moist north slopes South Fork, Santa Ana River, San Bernardino Mts., California, along the lower edge of the Canadian Zone at $2600 \mathrm{~m}$. alt., Hall, no. 7610. Nearest to S. serra integriusculus Gray, differing mainly in having all the leaves linear and entire. 
4. S. ionophyllus Greene, Pitt. ii. 20 (1889).

Erect from a thick perennial caudex: stems several, 2 to 4 dm. high, densely leafy below, nearly naked above the middle: herbage lightly floceose-woolly when young but early glabrate, inclined to become reddish especially on the lower parts : lower leaves thick and somewhat fleshy, orbicular, 1 to $3 \mathrm{~cm}$. wide, cordate at base or somewhat tapering to the petiole (this 2 to 6 cm. long), coarsely crenate: middle cauline leaves few, pinnately parted into linear lobes or the terminal lobe commonly broader and crenate or coarsely toothed: heads in a rather loose terminal cyme (oceasionally solitary): involucre campanulate, 8 to $10 \mathrm{~mm}$. high, many-flowered, sparingly calyeulate and more or less white-tomentose at base; bracts 15 to 22 , lanceolate: rays showy, light yellow : achenes cylindric, 10-nerved, 5-angled by the strong alternate nerves, glabrous.

Upper Sonoran and Transition zones: Tehachapi, Kern Co.. Jun. 25, 1889, Greene (type); Swarthout Cañon, San Antonio Mts., Jun., 1899, Hall: head of Rock Creek, San Gabriel Mts., Jul., 1893, Davidson; Corkscrew Falls of Bear Creek, San Bernardino Mts., 2000 m. alt., Parish, no. 3604 : Fish Creek, San Bernardino Mts., 2000 m. alt., Grinnell, no. 30 (largest leaves only $1.3 \mathrm{~cm}$. wide).

Many forms of this species are found in the mountains of Southern California and several of the extreme variations have received specific names. The characters on which they are founded, however, are not constant, as shown by the presence of connecting forms. In the typical form the caudex is stout and horizontal, in others it is short, erect, and multicipital. But plants otherwise identical and gathered at the same locality differ in this respect, and the direction the caudex takes is of course influenced by the slope on which the plants grow. The amount of woolliness is likewise an elusive character. In certain specimens some of the basal leaves are green and naked, while other leaves just above them are white-tomentose (Parish, no. 3718). The outline of the leaf may be of value in segregating varieties but is too variable to furnish specific characters. The rounded basal leaves are seldom more than coarsely crenate or dentate; yet in many specimens we find rounded crenate leaves neighboring with 
pinnately parted leaves in which the number of lobes varies from one to five (Mrs. Wilder, no. 244, in part; Parish, no. 3604 ; Hall, no. 1456). In type specimens the leaves are generally larger than in any others I have seen, but one of these (on Univ. Calif. sheet no. 35995) has no leaf more than $15 \mathrm{~mm}$. wide. The number and height of the stems are of course variable characters.

A low form not yet segregated is represented by my no. 1456 from Lytle Creek Cañon, San Antonio Mts., $1830 \mathrm{~m}$. alt., in the Lower Transition Zone. These specimens are only 1 to $1.5 \mathrm{dm}$. high : leaves mostly basal on the summit of a thick caudex, rather small, dentate to pinnatifid: cyme 1 to 3 -headed, the involucre sometimes $1 \mathrm{~cm}$. high. Two other forms, both of which have received specific names, may be characterized as follows:

Var. Bernardinus (Greene) Hall, comb. nov. S. Bernardinus Greene, Pitt. iii. 298 (1898). More slender than typical $S$. ionophyllus, 1.5 to $3 \mathrm{dm}$. high: tomentum rather persistent: leaves crowded at the base; the blade orbicular or cuneate-obovate, .5 to $1 \mathrm{~cm}$. wide, merely dentate or rarely a pair of small lobes (in the petiole: heads mostly 3 to 10 in each terminal cyme.-Dry hillsides in the Transition Zone at Bear Valley, San Bernardino Mts., 2100 m. alt., Parish, nos. 1450, 3718, and Hall, no. 7557.

Var. sparsilobatus (Parish) Hall, comb. nov. S. sparsilobatus Parish, Bot. Gaz. xxxviii. 462 (1904). Very slender, 1 to $2 \mathrm{dm}$. ligh : herbage tomentose in the types but green and nearly devoid of tomentum in some specimens collected under the same number: leaves usually crowded in a basal tuft, sometimes clothing the stem to the middle; blade 1 to $2 \mathrm{~cm}$. broad, occasionally roundish and merely dentate, more commonly pinnatifid and the 3 to 5 broad lobes entire or coarsely toothed: heads mostly 2 to 4 in each terminal cyme, or not rarely solitary.-Transition Zone of the San Bernardino Mts. from the upper Santa Ana River to Mt. San Gorgonio; not common in any one place but well distributed, usually in open forests of White Fir: Barton Flats and South F'ork, 2125 to $2600 \mathrm{~m}$. alt., Mrs. Charlotte M. Wilder, no. 244 (type, in Herb. Parish); Upper Santa Ana Cañon (Coon Creek, ete.) to Dry Lake, 2300 to $2700 \mathrm{~m}$. alt., Hall, nos. 7511, 7575, 7626 . 
5. S. eurycephalus T. \& G., in Gray, Pl. Fendl. 109 (1849). S. Breweri Davy, Eryth. iii. 116 (1895).

Rather stout, erect, 1 to $7 \mathrm{dm}$. high, from a perennial root: herbage nearly glabrous or (in northern forms) tomentose, commonly a slight woolliness at least in the axils of basal leaves: lower leaves 1 to $3 \mathrm{dm}$. long including the long petiole, irregularly pinnately parted or divided, the divisions diminishing in size from the broad rounded terminal lobe to the minute and narrow lower ones; middle eauline leaves narrower and with narrower acute divisions, these commonly lanceolate to cuneate and variously lobed or incised: heads 3 to 30 , in a loose terminal cyme; bracts of the inflorescence linear-lanceolate or subulate, small : involucre 8 to $11 \mathrm{~mm}$. high; bracts 10 to 20 , linear-oblong, acute, scarious-margined, the outer calyculate ones few and very short: rays 7 to 12 , oblong, 8 to $16 \mathrm{~mm}$. long.

Upper Sonoran Zone, commonly on moist grassy slopes: Tejon Pass, Los Angeles Co., 1280 m. alt., Parish, no. 1893, and Hall, no. 6262 ; Fort Tejon, Kern Co., Hall, no. 6273 ; Tehachapi Pass, Kern Co., May, 1889, Brandegee (herbage scurfy), and Jul., 1895, Davidson (glabrous); Blue Mt., Kern Co., Hall \& Babcock, no. 5000 ; Paso Robles, San Luis Obispo Co., Apr. 23, 1899, Barber; thence north through the Coast Ranges to northern and northeastern California.

With the exception of Mr. Brandegee's collection, all of the specimens eited are glabrous save in the leaf-axils, and these often also glabrous. In northern California, at least the leaves are commonly white-tomentose even at time of flowering, but some from even so far north as Modoc Co. (Goose Lake Valley, Mrs. Austin) are quite smooth and green. It will probably be found that woolly plants come only from arid places, the most woolly ones at hand being from very dry soil in the Sacramento Valley.

6. S. Douglasii DC., Prodr. vi. 429 (1837). S. Blochmanae Greene, Eryth. i. 7 (1893).

Stems branching from the suffrutescent base and forming a bushy plant usually 1 to $1.5 \mathrm{~m}$. high, leafy up to the inflorescence: herbage at first whitish-tomentose, later more or less glabrate: 
lower leaves pinnately divided into 5 to 9 narrowly linear revolute lobes, the upper with only 3 lobes (the middle one several times larger), or the uppermost entire: heads in broad terminal open cymes: involucre 8 to $10 \mathrm{~mm}$. high, broadly turbinate; the bracts linear with attenuate tips, dorsally carinate below: rays about 13 , the ligules about $10 \mathrm{~mm}$. long : achenes linear, pubescent.

Common throughout Southern California in the Upper Sono, ran Zone, especially in sand-washes and other gravelly places; north to Lake Co. and east to Nebraska. S. Blochmanae is apparently a form with glabrous herbage and entire leaves. A plant in the botanic gardens at Berkeley has the erect woody stem and the habit of typical $S$. Douglasii. Specimens gathered by Miss Eastwood (no. 281) at the type locality have small-sized heads and puberulent herbage. Further collections will probably demonstrate that the two species are not distinct.

S. Monoensis Greene, Leaflets, i. 221 (1906). Near S. Douglasii but lower, less woody, and the herbage always bright green and glabrous: copiously branched from the short woody portion; the branches $5 \mathrm{dm}$. or less high, but often long, flaccid, and decumbent. Near Southern Belle Mine, Mono Co., Heller, no. 8330; among rocks in the Panamint and Argus Mts. and in the Alabama Hills, all in Inyo Co., Hall \& Chandler, nos. 6946 , $7071,7181$.

7. S. Lyoni Gray, Syn. Fl. i. pt. 2, 456 (1886).

Somewhat suffrutescent at base, probably $1 \mathrm{~m}$. or so high, freely branching and leafy throughout: herbage at first tomentose, soon glabrate except for persistent dense tufts of wool in the leaf-axils and often a sparse tomentum on the under side of the leaves: leaves once or twice pinnately parted into broadly linear obtuse segments and lobes, sessile by an auriculate base or petiolate and the petiole dilated at base: inflorescence loosely cymose, the peduncles bearing a few subulate bracts: involucre broadly turbinate, 7 or $8 \mathrm{~mm}$. high; bracts linear, with acute pubescent tips, the medial line thickened and the margins scarious.

First collected by Nevin \& Lyon on San Clemente Island, acc. to Gray; Santa Catalina Island, May 20, 1890, Brandegee; San Quentin Bay, Lower California, Palmer, no. 644; San Martin Island, Brandegee. 
8. S. Californicus DC., Prodr. vi. 26 (1837).

A simple or diffusely branched erect annual, 1.5 to $4 \mathrm{dm}$. high : herbage glabrous or early glabrate: leaves linear to lanceolate, remotely toothed or lobed or some even pinnately parted with short obtuse lobes, the upper ones auriculate-clasping at the broad base: heads commonly several or more numerous on elongated peduncles : involucre 6 to $8 \mathrm{~mm}$. high, nearly naked at base: rays 15 to 20, oblong, 6 to $8 \mathrm{~mm}$. long: achenes canescent.

Lower California to Santa Barbara: very common in loose soil of the chaparral belt and also on sand dunes along the seashore (where commonly robust and succulent). Feb.-May.

9. S. Mohavensis Gray, Syn. Fl. i. pt. 2, 454 (1886).

A slender much branched annual, a few $\mathrm{cm}$. to $4 \mathrm{dm}$. high: herbage glabrous: leaves ample, broadly oblong or oblanceolate, obtuse, all but the basal with broad clasping base, coarsely fewtoothed (the largest 2 by $7 \mathrm{~cm}$., but commonly much smaller): heads in a loose terminal cymose panicle; peduncles slender, bracteolate: involucre 7 or $8 \mathrm{~mm}$. high; bracts 12 to 15 , linear, acute, often penicillate but not black at tip; calyculate bracts few and minute: rays commonly wanting, when present usually deformed and not longer than disk (ace. to Gray) : achenes densely canescent.

Confined to the Desert Area: near the Colorado River, Lemmon, ace. to Gray; Signal Mt., Colorado Desert, Brandegee; Panamint Mts., Inyo Co., acc. to Coville; Lower Sonoran Zone, 900 m. alt., in Pleasant Cañon, Panamint Mts., Hall \& Chandler: no. 6910 .

10. S. sylvaticus L., Sp. Pl. 868 (1753).

A slender annual, branching more or less from the base, 1 to 3 or $4 \mathrm{dm}$. high : herbage glabrous or nearly so: leaves sessile by an auricled base, linear or oblong, somewhat pinnatifid with small oblong lobes, these entire or dentate: heads evidently peduncled, in loose terminal clusters: involucre narrow, $6 \mathrm{~mm}$. high; principal bracts 10 to 20 , not black-tipped; minute outer bracts acute, green or brown: rays about 5 , not over $1 \mathrm{~mm}$. long: achenes appressed-silky, the hairs short.

Seldom seen, or passed over for S. vulgaris : Lower California; 
San Diego, Brandegee (distr. by Baker under no. 3414 as $S$. aphanactis Greene, but rays present!); Saugus, Davy. Native of Europe and Asia.

11. S. vulgaris L., Sp. Pl. 867 (1753). Сомmon GroundSEL.

An erect annual, 1 to $3 \mathrm{dm}$. or more high: herbage somewhat succulent, glabrous or with a little loose tomentum: leaves sessile, auricled, pinnatifid, the lobes oblong and with irregularly dentate margin : heads in terminal cymose clusters : involucre 6 or $7 \mathrm{~mm}$. high ; principal bracts about 20, their tips black and often penicillate; small outer bracts several, black : achenes slightly pubescent.

Common in waste places, flowering throughout the year. Native of Europe.

S. PARryi Gray. The report that this Senecio grew in the San Bernardino Mts. was, with scarcely a doubt, due to an error in the label.

\section{Tribe 10. CyNareaE. Thistle Tribe.}

\section{ARCTIUM. BURDOCK.}

Coarse biennials, unarmed except for the hooked tips of the involucral bracts forming the bur. Leaves large and roundish, the lower on stout petioles. Heads hemispheric, medium sized, pink or purplish. Receptacle densely setose. Filaments glabrous. Achenes oblong. Pappus of numerous short and rigid or chaffy bristles falling separately.

1. A. Lappa L., Sp. Pl. 836 (1735).

Plant usually 1 or $2 \mathrm{~m}$. high: leaves more or less cordate at base, mostly green above, white-tomentose beneath: involucral bracts narrow, green and smooth, strongly uncinate.

An European weed, now establishing itself near a deserted garden at West Riverside, Jul., 1907, Reed.

\section{CARDUUS L. Thistle.}

Spiny herbs with mostly lobed or pinnatifid alternate or basal leaves, all of ours more or less tomentose. Heads large, solitary or clustered, homogamous (rarely dioecious); the flowers white, reddish, or crimson. Involucral bracts imbricate, the outer ter- 
minating in spines, the inner inocuous. Receptacle soft-bristly or hairy, not fleshy. Corollas tubular, their segments linearfiliform. Achenes compressed or 4-angled, smooth in all our species. Pappus a single series of bristles connate at the very base and deciduous as a whole.

The subgenus Cirsium, which includes all the native American thistles, is distinguished from Eucarduus only by the plumose pappus-bristles of all but the marginal achenes. Yet some botanists would receive it as a distinct genus.

Leaves moderately if at all decurrent.

Heads sessile or short-pedunculate, bracteose-leafy at base.

Involucral bracts entire, the innermost often with scarious tips.

Corolla-lobes with callous capitate tips: bracts of the involucre not appressed-imbricate, narrow 1. C. edulis.

'Corolla-lobes acute: bracts of the involucre appressed-imbricate, the short outermost ones ovate.

2. C. Drummondii.

Involucral bracts finely spinescent on the margins above the middle

3. C. maritimus.

Heads solitary on long peduncles, not bracteose-leafy at base.

Flowers red or crimson, the corolla-lobes longer than the throat........

4. C. occidentalis.

Flowers white or cream-color to pink, the corolla-lobes equalling or shorter than the throat.

5. C. Californicus.

Leaves strongly decurrent, the middle cauline ones for one-third their length: desert species.

6. C. Mohavensis.

1. C. edulis (Nutt.) Greene, Proc. Phila. Acad. for 1892, 362 (1893). Cirsium edule Nutt., Trans. Am. Philos. Soc. ser. 2, vii. 420 (1841). Cnicus edulis Gray, Proc. Am. Acad. x. 47 (1874).

Stem simple, robust but tender and succulent, 2 or $3 \mathrm{dm}$. high; pubescent and leafy up to the terminal cluster of nearly or quite sessile heads: leaves narrowly oblanceolate or oblong, sinuatepinnatifid, very prickly-ciliate but the prickles weak, the upper surface green, more or less white-tomentose beneath: heads depressed-globose: involucre 2.5 to $3 \mathrm{~cm}$. high, conspicuously arachnoid-woolly when young; bracts gradually tapering from a narrow base to a weak prickle or soft point, not very unequal: flowers dull purple or whitish, segments of the corolla shorter than the throat and callous-thickened at apex.

Rare at Pasadena and San Bernardino; near the sea-coast not far from Santa Maria, Santa Barbara Co., Miss Eastwood, no. 
847; middle California to British Columbia. Mr. Parish, who thinks that this is an introduced species in his district, writes that it first appeared at San Bernardino about 1884, by a roadside and that it is still confined to the immediate vicinity where first observed. It was not reported from Pasadena until 1896.

2. C. Drummondii (T. \& G.) Coville, Contr. U.S. Nat. Herb iv. 142 (1893). Cirsium Drummondii T. \& G., Fl. ii. 459 (1843). Cnicus Drummondii Gray, Proc. Am. Acad. x. 40 (1874). C. Hallii Parish, Eryth. vii. 97 (1899); not Gray.

Stem simple, $4 \mathrm{dm}$. or less high, glabrous and leafy up to the heads, which are terminally clustered: leaves oblong or oblanceolate in outline, from deeply sinuate-pinnatifid with spinulose lobes to nearly entire, somewhat arachnoid-woolly, especially beneath: involucre 3.5 to $4 \mathrm{~cm}$. high; its bracts chartaceous, the inner with weak scarious tips which vary from entire and acute to obviously dilated and fimbriate, the outer gradually shorter and becoming ovate, their tips acute and short-spinose: corollas white (or sometimes rose-purple), the lobes not longer than the throat: anthers very acuminate.

Julian, San Diego Co., Jun. 14, 1894, Brandegee; in meadows at Yucaipe, near Redlands, Parish, no. 4594 and Greata, no. 571; Mt. Pinos, in Ventura and Kern counties, Hall, nos. 6684, 6364; near Santa Maria, Santa Barbara Co., Miss Eastwood, no. 859; north to the Aretic Region.

Var. acaulescens (Gray) Coville, Contr. U.S. Nat. Herb. iv. 142 (1893). Cnicus Drummondii acaulescens Gray, Proc. Am. Acad. x. 40 (1874). Heads smaller, few or several, sessile in the center of a rosette of radical leaves.-Not rare in meadows of the Transition Zone from Lower California north. A mere form, passing directly into the species, with which it sometimes grows, as, for example, on Seymour Creek, Mt. Pinos, at 2000 m. alt.

3. C. maritimus Elmer, Bot. Gaz. xxxix. 45 (1905).

Stems succulent, numerous, branched to form a rounded bushy plant $1 \mathrm{~m}$. or so high: herbage clothed with a densely matted white wool : leaves 1 to $3 \mathrm{dm}$. long, narrowed to the base, from spinosely lobed to deeply pinnatifid; the segments tapering into long spines and spinose on the margins, the lower gradually 
reduced to spines of the broad rachis: heads sessile or subsessile among the upper leaves: involucre about $4 \mathrm{~cm}$. high; the bracts very unequal, imbricated, lanceolate-acuminate, terminating in a short spine and spinosely ciliate above the middle, straight and erect or ascending, cobwebby-pubescent: corolla-lobes broadlinear, acutish : anther-tips acute.

In saline soil near the coast of Santa Barbara Co. at Surf, Elmer, no. 3631. The only specimen I have seen is the type, preserved at the Stanford University Herbarium. A similar species, or perhaps only a form of this, has been gathered at Santa Maria by Miss Eastwood, whose specimens were unfortunately destroyed in the San Francisco fire. As I remember them they were much greener than Elmer's type, being nearly destitute of tomentum, and with more nearly equal bracts.

4. C. occidentalis Nutt., Trans. Am. Philos. Soc. ser. 2, vii. 418 (1841). Cnicus occidentalis Gray, Proc. Am. Acad. x. 45 (1874). Cirsium occidentale Jepson, Fl. W. Mid. Calif. 509 (1901).

Stout, 5 to $10 \mathrm{dm}$. high, white with a thick coating of cottony wool when young: leaves from sinuate-dentate to pinnatifid, not very prickly, glabrate above, canescent beneath: heads subglobose, on nearly naked peduncles: involucre 3 to $6 \mathrm{~cm}$. high; its bracts straight and subulate-lanceolate, with slender spines, not widely spreading, densely festooned with cobwebby hairs: flowers red or purple: corolla-segments longer than the throat: anthertips narrow and acuminate: pappus rather scanty.

San Diego Co. (Sweetwater, Miss Eastwood; near San Diego, Cleveland) to Oregon; most common toward the coast and on the islands but extending inland to the foothills of the San Bernardino, San Gabriel, and Sierra Liebre Mts.

Var. Coulteri (Harv. \& Gray) Hall, comb. nov. Cirsium Coulteri Harv. \& Gray, Pl. Fendl. 110 (1849); Eaton, Bot. King Exped. 195 (1871) ; Jepson, Fl. W. Mid. Calif. 508 (1901). Carduus venustus Greene, Proc. Phila. Acad. for 1892, 359 (1893).

Herbage loosely lanate, rarely becoming green: involucre 3 to $5 \mathrm{~cm}$. high, arachnoid-woolly (glabrate in specimens from the North Coast Ranges); its bracts lanceolate, gradually narrowed 
into a slender spine; the outer ones appressed at base, then spreading, the tips either again incurved or straight or deflexed; innermost bracts erect: flowers bright crimson: corolla-lobes longer than the throat.-Zaca Mt., Santa Barbara Co., Jun., 1902 , Miss Eastwood; eastern base of Mt. Pinos, Ventura Co., Hall, no. 6693 ; inner Coast Ranges and Sierra Nevada Mts. to Nevada.

Var. candidissimus (Greene) Hall, comb. nov. C. candidissimus Greene, Proc. Phila. Acad. for 1892, 359 (1893). Whole herbage almost snow-white with a close persistent tomentum: bracts of the involucre appressed at base, all but the innermost squarrose-spreading or recurved from the middle, festooned with cobwebby hairs: flowers crimson: corolla-segments longer than the throat, their tips somewhat dilated.-Near the coast at Santa Barbara, ace. to Greene; San Emigdio Cañon and Tehachapi, Kern Co., 1894, Miss Eastwood: plentiful in northeastern California.

Typical $C$. occidentalis belongs to the Coastal Subarea; the var. Coulteri to the mountains bordering on the hot interior valleys and deserts ; var. candidissimus is apparently a mere form of var. Coulteri. In traversing these areas all gradations from the species into its varieties are met with. Intermediate forms between the type form and var. Coulteri are plentiful in the vicinity of Elizabeth Lake, Los Angeles Co. The bracts of var. candidissimus seem much more rigid than those of var. Coulteri, but when the dense wool is removed this apparent difference vanishes.

5. C. Californicus (Gray) Greene, Proc. Phila. Acad. for 1892, 359 (1893). Cirsium Californicum Gray, Pacif. R. Rept. iv. pt. 5, 112 (1857). Cnicus Californicus Gray, Proc. Am. Acad. x. 45 (1874). Carduus lilacinus and C. neglectus Greene: Bull. Calif. Acad. ii. 404 (1887).

Stem tall and paniculately branching, often 15 to $25 \mathrm{dm}$. high, very leafy toward the base, the white wool more or less deciduous, leaves narrow, mostly 1 to 2 or $3 \mathrm{dm}$. long, from sinuately to deeply pinnatifid, moderately spinose : heads solitary on the long peduncles: involucre hemispheric, somewhat woolly, 2 to $3 \mathrm{~cm}$. high; outer bracts with coriaceous base and lanceolate spreading but at last incurved upper portion, the terminal prickle slender; 
inner bracts straight, their herbaceous tips often crispate: corollas cream-color, white, or rarely purple; lobes shorter than the throat: anther-tips ovate-acuminate.

Occasional in dry sandy soil: San Pedro Martir, Lower California, Brandegee; Palm Springs, Colorado Desert; San Jacinto Mt., to 1600 m. alt.; Reche Cañon, near San Bernardino; Santa Catalina Island; Los Angeles; Ojai; Elizabeth Lake; Mt. Pinos; thence north to Placer Co.

Var. Bernardinus (Greene) Parish, MS., comb. nov. C. Bernardinus Greene, Proc. Phila. Acad. for 1892, 361 (1893). Stem slender, not very tall: leaves narrow, rather sparsely spinose: heads globose when young, hemispheric in age: involucre only 1.5 to $2 \mathrm{~cm}$. high, sparsely tomentose, glabrate; bracts appressed, somewhat imbricated, the outer minutely ciliate and with weak erect or spreading spines : corolla-lobes about equalling the throat. -Dry hillsides of Little Bear Valley, San Bernardino Mts., Parish, no. 1686 (type collection); vicinity of San Bernardino, Parish, no. 3680 ; near Pomona, May 11, 1897, Chandler; Palomar, Aug., 1898, Brandegee, and May, 1901, Jepson; Valley Center, McClatchie, no. 1159; thence to San Diego, various collectors. 'i'he prevailing thistle in the Coastal Subarea of San Diego Co.

6. C. Mohavensis Greene, Proc. Phila. Acad. for 1892, 361 (1893).

Somewhat stout, strict or moderately branched, 10 to $15 \mathrm{dm}$. high: leaves from narrowly lanceolate to oblong in outline, the lobes not overlapping, bearing numerous yellow spines, the middle cauline decurrent on the stem for one-third their length or more and all except the very lowest manifestly decurrent: involucre oblong, becoming hemispheric, $2 \mathrm{~cm}$. high; its bracts ovate and fully equalled by their slender at length deflexed spines : corolla said to be reddish, the acute lobes equalling the throat: anther-tips attenuate-subulate: pappus of outer achenes scabrous, of the others plumose except at the tip.

In alkaline meadows about springs in the Mohave Desert: Rabbit Springs, Parish, no. 1834 (duplicate type); Warm Springs (Newberry), Parish, no. 1261; Providence Mts., May 26, 1902, Brandegee (in a robust, large-headed form); Cushenberry Springs, acc. to Parish. 
C. ochrocentrus (Gray) Greene is to be expected along our northeastern borders. It differs from $C$. Mohavensis in its pinnatifid scarcely decurrent leaves.

\section{CYNARA L.}

Mostly robust herbs with alternate pinnatifid leaves and very large solitary globose heads. Involucre imbricated; its bracts broad, coriaceous, terminating in long spines (or spineless in the cultivated varieties). Receptacle fleshy, alveolate-fimbrillate. Flowers all perfect. Corolla tubular, the segments narrow. Achenes obovate-oblong, 4-angled, smooth. Pappus in several series; its bristles connate at base and deciduous in a ring, plumose or those of marginal achenes smooth. An Old World genus, two species sparingly naturalized in California.

Leaves and involucral bracts unarmed .1. C. Scolymus. Leaves and involucral bracts spinose 2. C. Cardunculus.

1. C. Scolymus L., Sp. Pl. 827 (1753). ARtichoke.

Stem fleshy, striate, corymbosely branched above: leaves very ample, bipinnatifid, the lobes acute but scarcely spinose, tomentose at least beneath: heads $6 \mathrm{~cm}$. or more wide: outer bracts of the involucre with thickened obtuse or acute tips; the inner bracts with scarious tips: flowers blue.

An occasional escape from gardens near Los Angeles, acc. to Abrams.

2. C. Cardunculus L., Sp. Pl. 827 (1753). Cardoon.

Perhaps only a cultural variety of $C$. Scolymus : leaf-lobes and involucral bracts short-spinose.

A garden escape at San Bernardino and well established at Trujillo's Ranch, San Diego Co., both ace. to Parish. ${ }^{60}$

\section{SILYBUM Vaill.}

Annual or biennial herbs with very ample prickly clasping leaves, these smooth and shining above and very conspicuously blotched with white along the veins. Heads very large, solitary

60 Eryth. vii. 97 (1899). 
at the ends of the branches, homogamous. Bracts of the involucre broad, appressed, bearing an abruptly spreading spine which is broadly lanceolate or ovate and ciliate-prickly toward the base. Flowers purple. Corollas with filiform tube conspicuously dilated below the narrowly linear lobes. Pappus-bristles in several series, flattish, minutely barbellate. Two species, natives of the Mediterranean Region, one of them becoming naturalized in California.

1. S. Marianum (L.) Gaertn., Fruct. ii. 378 (1791). Carduus Marianus L., Sp. Pl. 823 (1753). Milk Thistle.

Branching, 10 to $20 \mathrm{dm}$. high : lower leaves $5 \mathrm{dm}$. or more long and over $1 \mathrm{dm}$. wide, sinuate-pinnatifid, strongly undulate at the sinuses; upper leaves smaller, merely spinulose-toothed: heads 2.5 to $5 \mathrm{~cm}$. broad exclusive of the stout spreading or recurved spines, these often $3 \mathrm{~cm}$. long.

Sparingly introduced: Riverside; San Bernardino; Santa Catalina Island; Oak Knoll and El Monte, acc. to Davidson; coast of Ventura Co.

\section{Centaurea L. Star Thistle.}

Erect or diffuse usually rigid herbs with alternate leaves and medium-sized or large heads. Involucre ovoid or globose, the bracts imbricated and ending in a needle-like spine or in a fringed or toothed (rarely entire) appendage. Receptacle densely bristly, the bristles persistent. Flowers all tubular, the marginal much larger and neutral or the heads homogamous. Achenes somewhat compressed, mostly smooth, notched just above the base, indicating the oblique or lateral attachment. All our species naturalized from Europe.

Flowers yellow: involucral bracts spinose.

Plant erect, branching mostly above the base: spines .5 to $1 \mathrm{~cm}$. long 1. C. Melitensis.

Plant diffuse, branching from the base: spines 1 or $2 \mathrm{~cm}$. long

2. C. solstitialis.

Flowers blue (varying to white or purple): involucral bracts merely fimbriate 3. C. Cyanus. 
1. C. Melitensis L., Sp. Pl. 917 (1753). Tocalote.

An erect commonly much branched annual, 3 to $8 \mathrm{dm}$. high, with a roughish indument, the stems narrowly winged by the decurrent leaves: basal leaves pinnatifid, the upper narrow and mostly entire: heads terminal and solitary, or 2 or 3 together: involucre $1 \mathrm{~cm}$. high, its bracts rigid, the outer with palmatifid spine, the intermediate and inner ones with a rigid spine 5 to 10 $\mathrm{mm}$. long which is either simple or with divaricate short spines at base: flowers yellow: pappus-bristles in about 3 rows, the middle row long, the outer and inner very short.

A common introduced weed in waste places and fields.

2. C. solstitialis L., Sp. Pl. 917 (1753). Yellow Star THistLe.

Diffuse, branching from the base, 3 to $8 \mathrm{dm}$. high, from an annual root, cottony-pubescent: basal leaves pinnatifid; cauline leaves linear, entire, rather closely ascending, decurrent on the stem as long narrow wings : heads all solitary at the ends of the branches, ovoid-globular: bracts much like the preceding except that the spines of the intermediate ones are mostly 1 to $2 \mathrm{~cm}$. long and that the innermost bracts end in a small shining appendage: flowers bright yellow: outer pappus of short squamellae, inner pappus of copious slender bristles.

Sparingly introduced at San Diego, ace. to Gray, but not found by recent collectors ; El Rosario, Lower California, Brandegee; middle California. Native of Europe.

\section{C. Cyanus L., Sp. Pl. 911 (1753). Bluebottle.}

An erect annual, 3 to $6 \mathrm{dm}$. high, lightly flocculent-tomentose when young: leaves linear, entire or the lower rarely dentate or pinnatifid: heads terminating naked peduncles : involucre $1.5 \mathrm{~cm}$. high, fringed with a scarious fimbriate border: flowers deep blue; marginal corollas much enlarged, ray-like: pappus-bristles unequal.

Los Angeles, Nevin, acc. to Parish ${ }^{61}$ as a garden escape. Native of Europe.

61 Bot. Gaz. xxxviii. 462 (1904). 
Tribe 11. MUtisieae. Mutisia Tribe.

\section{PEREZIA Lag.}

Perennial branching herbs. Involucre imbricated; bracts dry, chartaceous or coriaceous. Reeeptacle flat, usually naked. Flowers never yellow. Style-branches flattened above, truncate. Achenes elongated-oblong, terete, sometimes narrowed at apex but not beaked. Pappus of many capillary scabrous bristles.

1. P. microcephala (DC.) Gray, Pl. Wright. i. 127 (1852). Acourtia microcephala DC., Prodr. vii. 66 (1838).

Somewhat stout, commonly $1 \mathrm{~m}$. or more high, leafy : herbage scabrous-puberulent and minutely glandular: leaves thin, 1 to 2 $\mathrm{dm}$. long by 3 to $8 \mathrm{~cm}$. broad, oblong, mostly acute, sessile by a broad or clasping base, finely and closely denticulate: heads numerous, in terminal cymose panicles, 10 to 15 -flowered: involucre 7 to $9 \mathrm{~mm}$. high; bracts oblong, abruptly acuminate or mucronate: corollas rose-color or whitish or pure white, bilabiate, the outer lip broad and 3-toothed, inner 2-lobed: pappus white, soft.

Rather common in the chaparral belt of the Upper Sonoran Zone from Santa Rosa Island (Brandegee) and San Luis Obispo Co. (Templeton, Alfred Carling) to western San Diego Co.

\section{TRIXIS P. Browne.}

Ours a low desert shrub with medium-sized heads and yellow flowers. Involucre little if at all imbricated; the proper bracts 8 to 12 , equal and in a single series, or in two unequal series. Receptacle mostly pilose. Style-branches flattened above, truneate. Achenes slender, tapering to the summit or beaked, 5-costate. Pappus soft, copious.

1. T. angustifolia latiuscula Gray, Syn. Fl. i. pt. 2, 410 (1884). T. suffruticosa Wats., Bot. Calif. ii. 459 (1880).

An erect bushy shrub about $6 \mathrm{dm}$. high, leafy up to the heads : herbage minutely glandular-puberulent, perhaps sometimes glabrate, said to be strongly scented with the odor of wormwood: leaves lanceolate, narrow at base, acute, entire or sparingly denticulate, usually 2 to $4 \mathrm{~cm}$. long by 8 to $12 \mathrm{~mm}$. broad: heads 
cymose or solitary at the ends of short branchlets, leafy-bracted: proper involuere about $15 \mathrm{~mm}$. high, shorter than the flowers and pappus; bracts about 10 , linear, acute, traversed by a strong midrib which becomes thickened at base: flowers bright yellow, bilabiate, outer lip of the marginal ones $6 \mathrm{~mm}$. long: achenes glandular.

In stony or gravelly soil of the Lower Sonoran Zone from the Colorado Desert to Arizona and Mexico: West, Andreas, and Palm Cañons, all near Palm Springs; Whitewater; Chuckawalla Wash; San Felipe; Mountain Spring Grade; ete.

\section{Tribe 12. CiCHORIEAE. Chicory Tribe.}

\section{CICHORIUM L.}

Erect herbs, the leaves mostly near the base, those of the stiff branching stem reduced and bract-like. Receptacle without bracts. Bracts of the oblong involucre herbaceous, in 2 series; the outer somewhat spreading; the inner erect, the lower part half-enfolding the marginal achenes. Achenes 5-angled, truncate, beakless. Pappus of 1 to 3 series of short blunt paleae.

\section{C. Intybus L., Sp. Pl. 813 (1753). Chicory.}

Stem erect from a deep taproot, 6 to $12 \mathrm{dm}$. high: herbage more or less hispid: radical leaves runcinate-pinnatifid, spatulate in outline, narrowed to a petiole, 6 to $12 \mathrm{~cm}$. or more long; upper leaves much smaller, lanceolate, with clasping base: heads in sessile clusters along the nearly naked branches: flowers blue or rarely white.

A native of the Old World, adventive at San Diego, at Bernardino, acc. to Parish, near Los Angeles, acc. to Abrams, and to be expected elsewhere as a garden escape.

\section{ATRICHOSERIS Gray.}

Glabrous desert annual with broad basal leaves and a tall solitary scape, cymosely branched above. Involucre of about 15 equal linear acute bracts and several small outer ones. Receptacle scrobiculate. Achenes oblong with corky-thickened pericarp. Pappus none. 
1. A. platyphylla Gray, Syn. Fl. i. pt. 2, 410 (1884). Malacothrix platyphylla Gray, Proc. Am. Acad. ix. 214 (1874). ToBACCO-WEED.

Scape commonly 3 to $8 \mathrm{dm}$. high, obseurely striate, white and shining, ending above in a diffuse cymose panicle: radical leaves obovate, obtuse, sessile, 5 to $10 \mathrm{~cm}$. long, 2.5 to $4 \mathrm{~cm}$. broad, spinulose-denticulate; cauline leaves reduced to minute scale-like bracts of the inflorescence: involucre $6 \mathrm{~mm}$. high; its bracts with scarious margins: ligules about $1 \mathrm{~cm}$. long, quadrate or oblong, sharply 5 -toothed at the truncate apex, white: achenes white, 4 $\mathrm{mm}$. long, somewhat pubescent, the truncate apex with no trace of a border; ribs corky-thickened at maturity, 5 of them usually more so than the others, rendering the achene obtusely 5 -angled.

A winter and spring annual, its period of flowering depending upon the rains, confined to gravelly mesas and washes in the Lower Sonoran Zone of the Desert Area. Quite common on the Colorado Desert, from Mecca east, and on the southern Mohave Desert, from the Ord Mts. east, Hall, nos. 5834, 5854, 6033, 6084, 6126, 6246, 6814 ; Funeral and Grapevine Mts., Inyo Co., Coville \& Funston, nos. 576, 975; east to Arizona and Utah.

\section{MICROSERIS Don.}

Herbaceous plants, mostly acaulescent or short-stemmed, glabrous or slightly puberulent. Leaves chiefly in a basal tuft, pinnatifid with mostly linear and often falcate lobes, or entire in the same species. Peduncles one-headed. Main bracts of the involucre nearly equal but with short outer ones at base or unequal and loosely imbricated. Ligules short, yellow, inconspicuous in dried specimens. Achenes slender-fusiform, or turbinate, or cylindric, ribbed, mostly truncate. Pappus-paleae 5 to 10. each with a more or less elongated scabrous or short-plumose awn.

Our first three species fall into the section Eumicroseris (Calais $\S$ Eucalais DC.); the fourth and fifth into the section Uropappus (Calais \& Calocalais DC.); the last into the section Scorzonella. These sections are treated by some authors as distinct genera, but they are very similar in general appearance and it is difficult to find constant technical characters of importance on which to 
separate them. Uropappus is distinguished from Eumicroseris by its erect heads on more or less swollen peduncles and by its pappus-paleae being cleft at the tip. Scorzonella has the nodding heads (in anthesis) of Eumicroseris and paleae either entire, as in that section, or cleft, as in Uropappus, but is best marked by its enduring root, imbricated involucre, and long ligules. The achenes have swollen tubercle-like bases only in Eumicroseris. The pappus-paleae are usually 5 in Eumicroseris, but 10 in its type species; always 5 in Uropappus; usually 10 but occasionally 5 in Scorzonella.

A.-Annuals: pappus-paleae mostly short, abruptly or gradually passing into a slender awn: heads nodding in the bud; peduncles not enlarged at summit. (\$ Eumicroseris.)

Paleae reduced to a triangular base or obsolete. 1. M. elegans.

Paleae conspicuous, $2 \mathrm{~mm}$. or more long.

Awns longer than the paleae 2. M. Douglasii

Awns much shorter than the ovate paleae. 3. M. platycarpha.

B.-Annuals: pappus-paleae elongated, flat, cleft at tip; the awn proceeding from the cleft: heads erect and peduncles enlarged at summit. (§ Uropappus.)

Achenes attenuate to a beak: pappus clear white or brownish

..4. M. linearifolia.

Achenes truncate: pappus dull brown or sordid

5. M. Lindleyi.

C.-Perennial with fusiform taproot. (\$ Scorzonella.)

Involucre imbricated: ligules elongated: pappus-paleae 10...6. M. montana.

1. M. elegans Greene, in Gray, Syn. Fl. i. pt. 2, 419 (1884).

Scape slender, often decumbent at base, a few $\mathrm{cm}$. to 1 or even $3 \mathrm{dm}$. high : leaves variable: involucre 6 to $8 \mathrm{~mm}$. high : achenes 2 to $2.5 \mathrm{~mm}$. long, gradually tapering from the broad truncate summit to the base: pappus brown or rufescent; the paleae ovatedeltoid, $1 \mathrm{~mm}$. or less long; the slender awn about $4 \mathrm{~mm}$. long.

San Diego, Brandegee, distr. Baker, Pl. Pacif. Coast, Sperm. \& Ferns, no. 820 (indicated by Dr. Greene as a new species); Santa Monica, 1891, Hasse (in Hb. Davidson, labeled M. aphantocarpha tenella, but certainly M. elegans); Santa Cruz Island, Apr., 1888, Brandegee; San Miguel Island, 1903, Beck; middle California. 
2. M. Douglasii (DC.) Gray, Proc. Am. Acad. ix. 209 (1874). Calais Douglasii DC., Prodr. vii. 85 (1838). C. cyclocarpha Gray, Pacif. R. Rept. iv. 113, t. 18 (1857). Microseris proxima Greene, Pitt. v. 8 (1902).

Scape usually 1.5 to $4 \mathrm{dm}$. high : leaves in the rosulate radical cluster many, pinnatifid: involucres broadly ovoid, or in age hemispheric, 1 to $1.5 \mathrm{~cm}$. high : achenes oblong-turbinate, thickish, contracted under the summit, about $5 \mathrm{~mm}$. long, the outermost usually white-villous: paleae of the pappus glabrous, or villous externally, ovate to orbicular, the margins incurved, 3 or $4 \mathrm{~mm}$. long, imbricated or convolutely overlapping, abruptly contracted into awns of about twice their length.

A species chiefly of western middle California but collected in meadows at Elizabeth Lake, Los Angeles Co., by Parish, no. 1902, and also reported from this locality by Davidson; Bimini Baths, near Los Angeles, Miss Eastwood, no. 93; north slope of the Santa Monica Mts., ace. to Abrams (under M. cyclocarpha); Santa Inez Mts., Brandegee. It belongs to the Upper Sonoran Zone.

3. M. platycarpha Gray, Proc. Am. Acad. ix. 210 (1874). Calais platycarpha Gray, Pacif. R. Rept. iv. 113 (1857). Microseries breviseta Greene, Pitt. v. 8 (1902).

Scapose peduncles $2 \mathrm{dm}$. or less high, several to numerous from the dense rosette of oblong entire or pinnatifid radical leaves: involucre about $1 \mathrm{~cm}$. high, subcylindric when young, becoming obovoid or broadly turbinate as the achenes mature; its outer bracts minute, ovate; principal bracts oblong, merely acute: achenes 4 or $5 \mathrm{~mm}$. long, more or less narrowed at base, scabrous on the prominent ribs and sometimes also pubescent or even villous, especially the outer: pappus-paleae dull white to smoky or almost black, more or less pubescent, broadly ovate, with incurved margins, convolutely overlapping, about as long as the achene, the awn much shorter.

Abundant on the mesas of western San Diego Co. and northern Lower California in the Upper Sonoran Zone.

Var. Parishii (Greene) Hall, comb. nov. M. Parishii Greene, Bull. Calif. Acad. ii. 46 (1886). Achenes slender: pappus-paleae lanceolate, $6 \mathrm{~mm}$. long, attenuate into an awn 2 to $4 \mathrm{~mm}$. long.With the species. In the type of the variety (Parish, no. 955, 
preserved at the Herbarium of the California Academy) the achenes are narrowed at the base and some of the pappus-paleae are brown, others smoky, at least those of the outer achenes conspicuously scabrous.

The variations in pappus and in achenial characters-color, shape, pubescence, relative length of parts-are so numerous that any attempt to characterize and name the different forms of this species would, if logically earried out, result practically in the naming of individual specimens. A number of forms now at hand are fully as distinct as many of those recently segregated as species and the number could undoubtedly be greatly extended by careful collection in western San Diego County.

4. M. linearifolia (DC.) Schultz Bip., Pollichia xii.-xxiv. 308 (1866) ; Gray, Proc. Am. Acad. ix. 211 (1874). Calais linearifolia DC., Prodr. vii. 85 (1838). Uropappus linearifolius Nutt., Trans. Am. Philos. Soc. ser. 2, vii. 425 (1841). Calais macrochaeta Gray, Pl. Fendl. 112 (1849). Microseris macrochaeta Schultz Bip., l. e. 309 ; Gray, Proe. Am. Acad. ix. 211 (1874). M. anomala Wats., Proc. Am. Acad. xxii. 475 (1887), and xxiv. 84 (1889).

Plant 1 to 4 or even $6 \mathrm{dm}$. high : stems or peduncles often several from the base, erect, the peduncle in robust plants thickened or fistulous under the oblong head: leaves linear (8 to $15 \mathrm{~cm}$. long, 1 to $5 \mathrm{~mm}$. wide) and with 2 or 3 to several pairs of more or less remote salient lobes or entire: achenes attenuate above into a beak, usually black: pappus deciduous, from silvery white to sordid, 12 to $15 \mathrm{~mm}$. long, including the very delicate awn, this about one-half the length of the deeply notched palea.

Common throughout Southern California except on the higher mountains; north to British Columbia and east to New Mexico; ranging from the Lower Sonoran well into the Transition Zone.

Mr. T. S. Brandegee ${ }^{62}$ has pointed out that in this and related species the awns of the pappus develope much earlier than the paleae, attaining their full length by the time the flower opens; while the paleae, then many times shorter, increase in length until the seed is mature, at which time they equal or exceed the

62 Zoe i. 126 (1890). 
awns. Since $M$. machrochaeta, as originally deseribed, differs from $M$. linearifolia only in its shorter paleae, it is thus seen to be but the immature state of this species.

5. M. Lindleyi (DC.) Gray, Proc. Am. Acad. ix. 210 (1874). Calais Lindleyi DC., Prodr. vii. 58 (1838). Uropappus Lindleyi Nutt., Trans. Am. Philos. Soc. ser. 2, vii. 425 (1841). Calais Farryi Gray, Pacif. R. Rept. iv. 112 (1857). Microseris Parryi Gray, Proc. Am. Acad. ix. 209 (1874). Calais pluriseta Greene, Pitt. i. 30 (1887) (?).

Stem short or scarcely any, but the stout naked scapes or scape-like peduncles usually 2 to $5 \mathrm{dm}$. high, scarcely thickened under the head: herbage glabrous, or furfuraceous-puberulent when young: leaves as in $M$. linearifolia, but rather broader: achenes commonly reddish-brown to gray, slightly narrowed toward the truncate summit: pappus dull brown or sordid, persistent, at maturity 12 to 15 or $18 \mathrm{~mm}$. long including the awn, this arising from a shallow notch and but little shorter than the mature palea.

On the plains and in the foothills ranging into the Transition Zone, from middle California to San Diego and on the islands; not so common as M. linearifolia and not reported from the Desert Area.

M. Parryi was based on immature specimens in which the paleae are exceeded by the awns and, as suggested by Mr. T. S. Brandegee, ${ }^{63}$ is probably only an early stage of $M$. Lindleyi. In the absence of specific characters on which to separate it, this species may well be suppressed, as is likewise the case of a number or others in this genus which would never have received names if their characterization had been deferred until complete and mature specimens were at hand.

Var. Clevelandi (Greene) Hall, comb. nov. Calais Clevelandi Greene, Bull. Calif. Acad. ii. 153 (1886). C. Parryi Greene, l. e. 49; not Microseris Parryi Gray. Uropappus Clevelandi Greene, Eryth. 1. 136 (1893). U. Lindleyi Clevelandi Jepson, Fl. W. Mid. Calif. 494 (1901). Seapes slender, not at all fistulousthickened: achenes not narrowed toward the summit: awn less

63 Zoe i. 126 (1890). 
than half as long as the palea.-San Diego, Cleveland, acc. to Greene; plains near Colton, San Bernardino Co., Parish, no. 2150 ; vicinity of Riverside, Hall, no. 3824; middle California. Specimens collected at San Diego, 1898, by Purpus, are intermediate between $M$. Lindleyi and var. Clevelandi, being moderately slender and with the pappus-awns slightly exceeding one-half the length of the palea.

6. M. montana (Greene) Hall, comb. nov. Scorzonella montana Greene, Bull. Calif. Acad. ii. 53 (1886).

Plant stout, often 4 or $5 \mathrm{dm}$. high, the stems somewhat leafy and usually several or numerous from the perpendicular fusiform perennial taproot : leaves elongated-lanceolate ( $2 \mathrm{dm}$. or less long), laciniate: involucre hemispheric, becoming $2 \mathrm{~cm}$. high; its outer bracts ovate, the inner oblong, all with slenderly acuminate often recurved tips: achenes columnar, truncate, 8 to $10 \mathrm{~mm}$. long; either glabrous or minutely scabrous on the ribs: pappus-paleae 10, linear-lanceolate, the tips acute or narrowly truncate, entire or slightly notched, $7 \mathrm{~mm}$. long, about equalled by the rigidly short-plumose awn.

Moist places in the Upper Sonoran Zone, not common: Tehachapi, Jun., 1884, and May, 1905, Mrs. Brandegee; hillsides at Elizabeth Lake, Jun., 1887, Parish; Crane Lake, Antelope Valley, May 6, 1895, Davidson; grown at Berkeley from seed gathered in Kern Co., by N. C. Wilson. The type specimens are among those saved from the San Francisco fire by Miss Eastwood.

\section{RHAGADIOLUS Tourn.}

Herbaceous annuals branching from the base, with either glabrous or hispidulous herbage. Basal leaves coarsely dentate or pinnatifid, the cauline often entire. Involucre of 1 series of equal narrow bracts which in age become indurated and concave enfolding the marginal achenes, and often an additional outer series of short linear bracts. Ligules short, yellow. Achenes narrow, terete or the outer subcompressed, 5 to 10-costate, the summit truncate to attenuate or beaked, the outer ones incurved, the inner ones straight. Pappus of marginal achenes a single series of short denticulate paleae; of central achenes a similar 
series of paleae alternating with stout bristles which are paleaceous-dilated at base.

1. R. Hedypnois All., Fl. Pedem. i. 226 (1785); not R. Hedypnois F. \& M., Ind. Sem. Hort. Petrop. iv. 46 (1835-46). Hedypnois polymorpha DC., Prodr. vii. 81 (1838). H. Cretica, Cav., Ic. i. t. 43 ; not Willd. Garhadiolus Hedypnois Jaub. \& Spach, Illustr. iii. 120 (1842-57).

Coarse herb, .5 to $2 \mathrm{dm}$. or more high, with several to numerous widely spreading branches: herbage green, short-hispid: lower leaves oblanceolate, sessile, 3 to $6 \mathrm{~cm}$. long, coarsely toothed ; cauline leaves few, linear or lanceolate, acute, mostly entire: heads solitary, on long peduncles which are more or less thickened above: involucre 8 or $10 \mathrm{~mm}$. high: principal bracts 10 to 15, becoming firm and linear in age, then incurved and embracing the marginal achenes: achenes terete, truncate, hispidulous on the nerves.

San Diego (near the Ostrich farm), Jun., 1906, Mrs. Brandegee; Mariposa Co., May, 1895, Congdon; Sonoma Co., Apr., 1900 , acc. to Miss Eastwood, who states that the plants are sometimes 6 to $9 \mathrm{dm}$. high ; ${ }^{64}$ Texas, acc. to Watson. ${ }^{65}$ Introduced from the Mediterranean Region.

\section{ANISOCOMA Gray.}

Seapes several from a strong taproot, each bearing a single rather large yellow-flowered head. Leaves all in a basal tuft. Involucre cylindric, the inner bracts linear and acute, the outer successively shorter and very obtuse, the outermost reduced to orbicular seales, all with green midrib and broad scarious margins. Receptacle flat, its scarious bracts linear. Achenes oblong or somewhat turbinate, truncate, crowned with a narrow entire border, 10 to 15-nerved, pubescent. Pappus bright white, of 10 to 12 plumose bristles in two series (the outer sometimes naked).

1. A. acaulis Gray, Bost. Journ. Nat. Hist. v. 111 (1845). Pterostephanus runcinatus Kell., Proc. Calif. Acad. iii. 20, f. 4 (1863).

64 Zoe v. 34 (1900).

65 Proc. Am. Acad. xviii. 110 (1883). 
Herbage glabrous except for the more or less persistent tomentum of the foliage: peduncles $3 \mathrm{dm}$. or less long, either erect or decumbent and radiating from the tuft of pinnately lobed radical leaves: involucre 2 or $3 \mathrm{~cm}$. high when fully mature; its bracts inclined to be edged with red toward their tips and the exposed portion spotted with reddish dots.

In dry sandy soil of the Desert Area and the surrounding ranges from San Jacinto Mt., Rock Creek, and Mt. Pinos north; also as a waif at San Bernardino, Parish. Although most common in the Lower Sonoran Zone, this species ranges well up into - the Transition, reaching an altitude of $2450 \mathrm{~m}$. on warm south slopes in the San Antonio Mts.

\section{HYPOCHOERIS L.}

Stems naked, commonly branched and bearing several longpeduncled heads. Leaves in a radical cluster or rosette. Flowers yellow. Involucre campanulate or cylindric, its bracts rather few, lanceolate, imbricated, appressed, the outer ones successively shorter. Receptacle flat, its scarious chaffy bracts thin and narrow. Achenes upwardly seabrous, the body 10-ribbed, narrowly oblong or fusiform, tapering upward into a slender beak, or the outermost truncate. Some of the outer pappus-bristles often short and not at all plumose.

IIerbage pubescent: achenes all beaked 1. H. radicata.

Herbage glabrous: outermost achenes truncate, inner ones beaked

2. H. glabra.

1. H. radicata L., Sp. Pl. 810 (1753). Gosmore.

Stems 5 to $20 \mathrm{dm}$. high, several from a fleshy perennial root, usually branching and bearing several peduncled heads: leaves hispid with spreading hairs, pinnatifid below the large terminal lobe into oblong obtuse lobes: rays longer than the involucre, which is disposed to twist slightly after anthesis: achenes al! beaked.

Reported by McClatchie as being introduced at Pasadena; streets of Redlands, Jun., 1907, Greata. 
2. H. glabra L., Sp. Pl. 810 (1753).

Scapes several, erect from a straight annual taproot, 1 to 5 $\mathrm{dm}$. high : herbage glabrous : leaves broadest above, denticulate to broadly toothed or saliently lobed: ligules scarcely longer than the involucre: outermost achenes truncate at summit, the others all beaked.

A naturalized weed: Pasadena, Grant; abundant on low hills back of Santa Barbara, 1907, Hall, no. 7738; sandhills near Santa Maria, 1906, Miss Eastwood, no. 366; Paso Robles, Cobb; Santa Cruz Island, ace. to Greene ${ }^{66}$; and northward.

\section{STEPHANOIMERIA Nutt.}

Tall and rather slender herbs, the stems either strict or paniculately branched. Upper leaves reduced to herbaceous bracts. Heads small, 3 to 20 -flowered. Flowers pink or flesh-color, open in the early morning, the ligules all equal. Involucre eylindric or rarely campanulate. Receptacle flat. Achenes oblong, shortlinear or somewhat turbinate, strongly angled, glabrous, often rugose, truncate at each end, the broad base hollowed at the insertion. Pappus-bristles white or sordid, more or less plumose.

Receptacle deeply pitted, hirsute: involucre imbricated: root perennial: young herbage woolly.

1. S. cichoriacea.

Receptacle naked: involucre not imbricated but calyculate at base with minute bracts, rarely one or two intermediate bracts.

Involucre 10 to 14 -flowered, $12 \mathrm{~mm}$. or more high: perennial with sharply lobed upper leaves

2. S. Parryi.

Involucre 3 to 6 (or 9 )-flowered, less than $12 \mathrm{~mm}$. high.

Perennials.

Stems herbaceous, erect and very slender

3. S. tenuifolia.

Stems woody below, spreading and nearly leafless above.

Branches rigid, mostly divaricate.

..4. S. runcinata.

Branches very slender, flexuous, ascending........5. S. myrioclada.

Annuals and biennials.

Pappus plumose almost throughout, the base scarcely thickened.

Herbage glabrous.

6. S. virgata.

Herbage white-tomentose when young. 7. S. tomentosa.

Pappus plumose only above; the naked base thickened or paleaceous, often toothed or giving off short secondary bristles

8. S. exigua.

66 Bull. Calif. Acad. ii. 405 (1887). 
1. S. cichoriacea Gray, Proc. Am. Acad. vi. 552 (1865). Ptiloria cichoriacea Greene, Pitt. ii. 133 (1890).

Root strong and woody, perennial : stems virgate, erect, stout, the whole plant 4 to $12 \mathrm{dm}$. high: herbage woolly when young; sometimes densely so, but early glabrate: leaves oblong or lanceolate, acute, narrowed to the sessile base, remotely and saliently toothed or some quite entire, the largest $2 \mathrm{dm}$. or more long and 1 to $3 \mathrm{~cm}$. wide: heads on short scaly-bracteate peduncles along the stems, about 12-flowered: involucre 12 to $15 \mathrm{~mm}$. high; the outer bracts imbricated in 2 or 3 series: receptacle with hirsute alveoli: achenes smooth, faintly 5-angled: pappus sordid, the 1 ts to 20 bristles plumose for their whole length.

Rocky slopes and cañons in the foothills (Upper Sonoran Zone) from Tejon Pass and the Santa Barbara Islands to the San Gabriel and San Bernardino Mts.

2. S. Parryi Gray, Proc. Am. Acad. xix. 61 (1883). Ptiloria Parryi Coville, Contr. U. S. Nat. Herb. iv. 144 (1893).

Plant $6 \mathrm{dm}$. or less high, from a perennial root: stem widely kranched throughout: leaves thickish, runcinate-pinnatifid; those near the heads small, somewhat spinulose-lobed: involucre 10 to 14-flowered: achenes smooth and even, with slender ribs : pappusbristles thickened, often united in twos or threes at the naked base, sordid.

A species of the Mohave Desert (Lower Sonoran Zone), and eastward to Utah: Alpine, Los Angeles Co., Parish, no. 1961; Rock Creek, ace. to Davidson; Mohave, Mrs. Curran; near Victorville, Hall, no. 6207 ; Rabbit Springs, Parish, no. 1835 ; Panamint Mts., Coville \& Funston, no. 755; Owens Valley, Hall \& Chandler, no. 7294 .

3. S. tenuifolia (Torr.) Hall, comb. nov. Prenanthes? tenuifolia Torr., Ann. Lyc. N. Y. ii. 210 (1828). Ptiloria tenuifolia Raf., Atl. Journ. 145 (1832). Lygodesmia minor Hook., Fl. Bor. Am. i. 295, t. 103 f. A (1833). Stephanomeria minor Nutt., T'rans. Am. Philos. Soc. ser. 2, vii. 427 (1841).

Stems herbaceous, from a perennial root, erect, with numerous ascending slender branches, the whole plant 1 to $5 \mathrm{dm}$. high : herbage pale, glabrous: leaves commonly erect, slender and almost grass-like, even the rameal mostly 2 to $5 \mathrm{~cm}$. long; the early 
lower ones more or less runcinate: heads terminal : involucre 8 to $10 \mathrm{~mm}$. high, usually of 5 principal bracts and 5 -flowered: achenes striate: pappus-bristles 15 to 25 , white or sordid, plumose throughout.

A species of the Sierra Nevada Mts. and northward : reported from the mouth of Mill Creek Cañon, San Bernardino Mts., by Parish, no. 4577; not seen by me.

4. S. runcinata Nutt., Trans. Am. Philos. Soc. ser. 2, vii. 427 (1841).

Stems woody at base, rigidly and intricately much branched, the nearly leafless branches divaricate or slightly ascending; forming rounded bushy plants 4 to $6 \mathrm{dm}$. high: herbage pale, glabrous: lower leaves runcinate; upper leaves linear-subulate, $5 \mathrm{~cm}$. or less long, many reduced to scales : heads solitary, on short peduncles scattered along the branches or terminating short geniculate branchlets : involucre 8 to $10 \mathrm{~mm}$. high, commonly of 5 principal bracts and as many or more short ealyculate ones: flowers 3 to 5: achenes narrowly oblong, striate: pappus-bristles 12 to 25 , sordid, plumose to near the base.

Lower Sonoran Zone of the Mohave and Colorado deserts from Antelope Valley, Palm Springs, and San Felipe east and north; also in Lower California; nowhere abundant. Nuttall's specimen came from "Big Sandy Creek, a rivulet of the Colorado." Rafinesque's Ptiloria pauciflora, of the Great Plains and Rocky Mts., is probably a different species.

Mr. L. H. Henderson ${ }^{67}$ has referred specimens from Whitewater, San Bernardino Co., Parish, no. 3228, as represented in the Gray Herbarium, to S. lygodesmoides M. E. Jones. The specimen in Herb. Parish under this number is easily referable to S. runcinata and differs from the description of S. lygodesmoides in its divaricate branches, in the involucre $(8 \mathrm{~mm}$. high) of 5 principal bracts, and in the pappus, which is plumose two-thirds the way down.

Ptiloria divaricata Greene, Eryth. i. 224 (1893) is doubtfully distinct from S. runcinata. In plants grown at Berkeley from seed gathered by N. C. Wilson, presumably with the type

67 Bull. Torr. Club xxvii. 349 (1900). 
specimens, near Caliente, Kern Co., the pappus-bristles are distinct to the base.

5. S. myrioclada Eat., Bot. King Exped. 198, t. 20, figs. 1 to 4 (1871).

Branches ascending, very slender: rameal leaves all reduced to scales $1 \mathrm{~cm}$. or less long: heads sometimes only 3 or 4 -flowered and involucral bracts reduced to 3 or 4 : otherwise as in $S$. runcinata, of which it is probably only a form.

Piute Creek, eastern San Bernardino Co. or western Nevada, Jun. 5, 1893, N. C. Wilson; Yosemite Valley, 1893, J. B. Lembert; first collected in Nevada by Watson, acc. to Eaton.

6. S. virgata Benth., Bot. Sulph. 32 (1844). Ptiloria virgata Greene, Pitt. ii. 130 (1890).

Stems rigid, virgate or with usually virgate branches, sometimes widely and paniculately branched, 3 to 20 or even $40 \mathrm{dm}$. high: herbage usually glabrous: lower leaves oblong or spatulate, often sinuate or pinnatifid; upper leaves linear, small and entire: heads subsessile along the naked branches, mostly 4 to 16-flowered: involucre $7 \mathrm{~mm}$. high : ligules reddish-purple on the back, lighter on the upper surface, sometimes clear white: achenes subclavate or oblong, longitudinally ribbed, the intervening spaces more or less rugose and traversed by a deep narrow groove: fappus clear white, plumose almost throughout, fragile but the base commonly persistent.

On the plains and in the foothills, very common throughout the Upper Sonoran Zone in Southern California, including the islands; north to Oregon, east to Utah. Jul.-Sept. This species attains its greatest development at San Diego, where there is also a puberulent form. Here the flowers are commonly 14 to 16 , not rarely 20 to 22 in a head.

Var. pleurocarpa (Greene) Hall, comb. nov. Ptiloria pleurocarpa Greene, Pitt. ii. 131 (1890). Achenes light-colored, the spaces between the ribs either plane or rugose but not grooved: pappus deciduous.-With the species on Mt. San Jacinto, at Riverside, Pomona, Cucamonga, Santa Monica, and north. In some plants, otherwise typical S. virgata, the pappus is deciduous; on others both light and dark-colored achenes may be found. 
Hence only one constant character remains to separate the variety from S. virgata and even this-the absence of the intercostal groove-is apparently somewhat variable.

7. S. tomentosa Greene, Bull. Calif. Acad. ii. 152 (1886). Ptiloria tomentosa Greene, Pitt. ii. 131 (1890).

Stout, ereet, $7 \mathrm{dm}$. or more high, from an annual or biennial (?) root: stem simple below, paniculately branched above: herbage white-tomentose when young, glabrate at least above: leaves spatulate or lanceolate, sinuate-dentate or the lower runcinatepinnatifid, $7 \mathrm{~cm}$. and less long: heads subsessile along the virgate branches, "5 to 8 -flowered": involucre $6 \mathrm{~mm}$. high; its principal bracts equal, the outer calyeulate ones minute: achenes 5-angled, rugose-tuberculate between the angles: pappus of numerous white bristles, plumose to the base, deciduous.

Central parts of Santa Cruz Island, Jul.-Aug., 1886, Greene, who only has collected it.

8. S. exigua Nutt., Trans. Am. Philos. Soe. ser. 2, vii. 428 (1841). S. coronaria Greene, Bull. Calif. Acad. i. 194 (1885). Ptiloria exigua Greene, Pitt. ii. 132 (1890).

Plant 2 to $6 \mathrm{dm}$. high: stem with numerous ascending or spreading branches, glabrous below, often minutely glandularpubescent above: lower leaves narrowly oblong, remotely lobed, auriculate-clasping, the upper cauline small and bract-like: heads seattered or somewhat paniculate, numerous : ligules at first rosecolor, soon turning sordid-yellow : involuere 6 or $7 \mathrm{~mm}$. high, of about 5 principal bracts, mostly 5 -flowered: ligules $5 \mathrm{~mm}$. long: achenes linear-oblong, 5-angled, with a double row of tubercles between the angles: principal pappus-bristles 8 to 18, plumose above, naked on the lower third, commonly united into 4 or 5 clusters by their thickened bases which are sometimes setulose or lacerate or some of the setae may split entirely away from the. central portion and form a row of short secondary bristles.

A species chiefly of the Desert Area and eastward but extending to Redlands and to Monterey Co. and reaching the coast in San Diego Co. The form with a secondary pappus of short seabrous bristles formed by the splitting off of setae from the principal ones comes from Riverside, Redlands, etc. Specimens 
from near Los Angeles also seem to belong here, as do others from Soledad Cañon. S. coronaria is the form in which the rappus-bristles are deciduous above the paleaceous base, leaving a crown of setose scales. The common form in southwestern San Diego Co. is intricately branched, the twigs very slender, the herbage conspicuously glandular, and the pappus that of the $S$ coronaria form. It apparently grades into typical $S$. exigua as regards all of these characters.

Var. pentachaeta (Eat.) Hall, comb. nov. S. pentachaeta Eat., Bot. King Exped. 199, t. 20, ff. 8, 9, 10 (1871). Ptiloria pentachaeta Greene, Pitt. ii. 133 (1890). Stem less branched, the branches ascending: herbage pale: pappus of only 5 or sometimes 7 bristles, all distinct to the base which is slightly dilated and commonly with a few minute teeth, plumose only on the upper half.-San Felipe, San Diego Co., Parish; Pacoima, San Fernando Valley, Barber, no. 184 (with secondary pappus of short bristles); Watermans, Mohave Desert, Mrs. Curran; northward into Inyo Co.; eastward to Arizona and Nevada. Differs from the species chiefly in the less plumose pappus-bristles and in the number of these, but this latter character inconstant.

S. SсноттіI Gray, Bot. Calif. i. 427 (1876), has been found only on the Gila River, Arizona, but is to be expected along our eastern borders. Similar to S. exigua but pappus of 5 or 6 linearlanceolate and blunt rigid scales or scariously margined awns, naked below and sparingly barbellate-plumose towards the summit; achenes minutely scabrous between the smooth angles.

S. Elata Nutt., Pl. Gamb. 173 (1847), said to be a blueflowered plant with narrowly linear leaves, a resinous herbage, ard plumose white pappus, collected long ago at Santa Barbara, has not been since seen.

Cheatadelpha Wheeleri Gray, Proc. Am. Acad. ix. 218 (1874) ; Rothrock, in Wheeler Rept. 182, t. 15 (1878). Similar to Stephanomeria, with which it is probably congeneric: involucre of 5 principal bracts and some minute calyculate ones, about $12 \mathrm{~mm}$. high : achenes short-linear, 5-angled, very smooth : pappus of 5 rigid upwardly tapering awns which bear on each side toward the base 3 to 7 rather shorter and slender rigid bristles.- 
Western Nevada, Wheeler, and near Pyramid Lake, Nevada, Lemmon, both. acc. to Gray; Wadsworth, Nevada, Miss Stokes; Gold Mt., Nevada, Purpus, no. 5953; Candelaria, Nevada, Shocklcy, no. 567; Eastern Oregon, Cusick, no. 2019.

\section{RAFINESQUIA Nutt.}

Stout and sometimes fistulous glabrous branching annuals. Leaves toothed or pinnatifid. Panicle more or less cymosely branching. Heads 15 to 30 -flowered. Involucre in anthesis cunical-cylindraceous. Flowers white, the outer ligules more or less tinged with rose-color; ligules unequal. Receptacle flat, naked. Achenes terete, with a few obscure ribs, excavated at the insertion but with callous thickening. Pappus-bristles capillary, 10 to 15, long-plumose from the base to near the tip.

Pappus dull white: achenes with very slender beak 1. R. Californica. Pappus bright white: achenes with very stout beak 2. R. Neo-Mexicana.

1. R. Californica Nutt., Trans. Am. Philos. Soc. ser. 2, vii. 429 (1841). Nemoseris Californica Greene, Pitt. ii. 193 (1891).

Robust, branching above, 3 to $25 \mathrm{dm}$. high: leaves oblong in outline, pinnatifid to denticulate or almost entire, sessile and auriculate-clasping or the lowermost narrowed to a winged petiole, $15 \mathrm{~cm}$. less or long; those of the inflorescence much reduced and often spinulose-toothed and angular : involucre 16 to $18 \mathrm{~mm}$. high, of 11 to 15 (or even 22) linear or lanceolate-acuminate main bracts with some loose subulate ones at base: ligules short, white: beak of achene as long as the body: pappus dull white.

Beneath foothill shrubs almost throughout the state; also reported from Oregon and Arizona. Very common in the Upper Sonoran Zone; only casual in the Lower Sonoran.

2. R. Neo-Mexicana Gray, Pl. Wright. ii. 103 (1853). Nemoseris Neo-Mexicana Greene, Pitt. iị. 193 (1891).

Plant 2 to $6 \mathrm{dm}$. high; the stem rather weak, branching : lower leaves oblong or oblanceolate in outline, from toothed to saliently lobed; the lower cauline narrower and runcinately parted into linear lobes; the uppermost reduced to minute usually spinulose bracts; all but the lowest with auriculate-clasping base: involucre narrow, in fruit about 20 (18 to 25 ) $\mathrm{mm}$. high, of 8 to 10 main 
bracts and some loose subulate ones at base: ligules white, veined externally with rose-purple, $15 \mathrm{~mm}$. or more long: beak of the achene very stout, tapering from the base: pappus clear white.

Common among shrubs in the Lower Sonoran Zone of the Desert Area: Antelope Valley and Coyote Cañon to Utah, the Rio Grande, and Lower California.

\section{TRAGOPOGON L.}

Tall and erect perennial herbs with slender fleshy taproots, alternate grass-like flaceid leaves clasping at the base, and large heads of purple or yellow flowers, which are open only during the morning. Involucral bracts in a single series, united at the very base. Rays 5-toothed at the truncate apex. Receptacle naked. Achenes muricate, 5 to 10-ribbed, long-beaked or the outermost beakless. Pappus-bristles connate at the base, plumose with interwebbed branches.

1, T. porrifolius L., Sp. Pl. 789 (1753). SALSIFY. VeGETABLE OYSTER.

Stem simple and robust, often $1 \mathrm{~m}$. or more high, bearing at the summit a single head on a long fistulous peduncle: herbage glaucous and perfectly glabrous except for a sparse woolly pubescence on the lower part of the leaves: longest leaves 20 or 30 $\mathrm{em}$. long, $2 \mathrm{~cm}$. wide at base, narrowly long-acuminate : involucre contracted above the broad base, 4 or $5 \mathrm{~cm}$. high; bracts all lanceolate-acuminate and keeled, the outer ones foliaceous: achenes $12 \mathrm{~mm}$. and the beak 15 to $20 \mathrm{~mm}$. long: pappus sordid, of about 5 slender bristles, exceeding the corolla-tube, plumose only toward the base.

Waste places around Los Angeles, San Bernardino, etc., as an escape from gardens.

\section{MALACOTHRIX DC.}

Chiefly herbaceous plants, a few woody at base, commonly with a radical cluster of leaves, the stems either leafy or almost naked. Heads small or medium-sized, solitary or panicled, never sessile, commonly nodding in the bud. Flowers yellow, white, or pinkish. Receptacle bristly or naked. Achenes short, truncate 
at apex, crowned with an entire or denticulate border, 10 to 15ribbed, terete or 4 or 5 of the ribs stronger than the others rendering the achene somewhat 4 or 5 -angled. Pappus-bristles soft, scabrous, more or less united at base and falling away together; 0i with 1 to 8 stronger ones which are more persistent.

Involucre imbricated in several series, all but the innermost bracts (whieh vary from oval to linear) orbicular or ovate and very obtuse, all silvery-scarious with a dark medial line 1. M. Coulteri. Involucre much less imbricated, its bracts lanceolate to linear, all acute.

Annuals, less than $6 \mathrm{dm}$. high.

Scapose: leaves all basal: peduncles monocephalous

2. M. Californica.

Caulescent: stems branching and bearing leaves, at least below.

Leaves and their lobes filiform, elongated: persistent pappusbristles 2 or more 3. M. glabrata.

Leaves and their lobes broader and shorter: persistent bristles only one or lacking.

Ligules about $1 \mathrm{~cm}$. long: desert species........4. M. sonchoides. Ligules $2 \mathrm{~mm}$. long: stems leafy only below: montane species. Flowers yellow: one pappus-bristle and a crown of setulose teeth persistent.

5. M. Clevelandi.

Flowers pale: pappus all deciduous 6. M. obtusa.

Ligules short: stems very leafy throughout.

Involucres 10 to $12 \mathrm{~mm}$. high: leaves and their lobes acute 7. M. foliosa.

Involucres 6 or $7 \mathrm{~mm}$. high: lower leaves with obtuse lobes 8. M. indecora.

Perennials, mostly with suffrutescent base (the herbaceous species with stems $1 \mathrm{~m}$. or more high).

Herbage white-tomentose when young: inner bracts of the involucre obtuse 9. M. incana.

Herbage essentially glabrous: involucral bracts attenuate.

Stems several, much branched from the base. 10. M. saxatilis. Stem solitary, usually simple below 11. M. altissima.

1. M. Coulteri Gray, Pl. Fendl. 113 (1849). Malacolepis Coulteri Heller, Muhlenbergia ii. 147 (1906). Snake's Head.

Annual, 1 to $6 \mathrm{dm}$. high: stem simple from the base, paniculately branched above: herbage glabrous and glaucescent: cauline leaves sinuately pinnatifid, broad or somewhat auriculate at the sessile base and with an elongated terminal lobe: heads subglobose: involucre 12 to 15 or $18 \mathrm{~mm}$. high; its bracts silveryscarious with a linear central portion green, regularly imbricated in several ranks, the short outer ones orbicular, the inner ones 
oval to lanceolate or linear: ligules light yellow: achenes 15ribbed and 4 or 5 -angled, the summit obscurely denticulate by projection of the ribs: 1 or 2 stouter pappus-bristles persistent.

Occurs sparingly from San Diego Co. and Santa Cruz Island to the San Joaquin Valley and extends to the borders of the desert (and S. Utah, Parry, no. 130), but not found in the mountains.

2. M. Californica DC., Prodr. vii. 192 (1838).

- Scapes several, 1.5 to 3 or $4 \mathrm{dm}$. high, from a dense rosette of radical leaves, bearing at their summits solitary heads of showy yellow flowers: herbage conspicuously woolly when young with very long and soft hairs: leaves pinnatifid into narrowly linear or almost filiform lobes: peduncles occasionally bearing a few scattered bractlets above: involucre 12 to $15 \mathrm{~mm}$. high; its bracts linear or subulate, in about 3 ranks : ligules $12 \mathrm{~mm}$. or more long : bristles of the receptacle delicate, usually present: achenes narrow, lightly striate: outer pappus of 2 persistent bristles and scme intervening minute teeth.

In sandy soil throughout the coastal slope, ascending the mountains to about $1400 \mathrm{~m}$; ; north to the Sacramento Valley.

3. M. glabrata (Eat.) Gray, Syn. Fl. i. pt. 2, 422 (1884). M. Californica glabrata Eat., Bot. King Exped. 201 (1871).

Basal branches ascending, leafy below, usually again branched above and bearing several heads: herbage glabrous throughout except the outer calyculate bracts of the involucre which are sometimes canescently pubescent: peduncles usually with a few bractlets above: leaves, flowers, etc., as in M. Californica.

Plentiful, especially in sandy places, in the Lower Sonoran \%one of the Colorado and Mohave deserts; also on the coastal siope at Lakeside, San. Diego Co., and near Riverside (Jurupa IIills, Gavilan Hills, etc.), north along the eastern side of the Sierras to Oregon and in the San Joaquin Valley to Fresno Co. In specimens collected near Piute Creek, by Norman C. Wilson: the persistent bristles of the pappus vary from 2 to 4 in number.

4. II. sonchoides (Nutt.) T. \& G., Fl. ii. 486 (1843). Leptoscris sonchoides Nutt., Trans. Am. Philos. Soc. ser. 2, vii. 439 (1841). 
Stem freely branching, the branches ascending and sparsely leafy except near the base: herbage glabrous or early glabrate: leaves oblong, or the upper narrowly lanceolate, pinnatifid with short callous-toothed lobes: peduncles $3 \mathrm{~cm}$. or less long: involucre about $8 \mathrm{~mm}$. high; its bracts linear-acuminate: ligules bright yellow, a full $\mathrm{cm}$. long: achenes 15 -striate, 5 of the ribs stronger than the others, rendering the achene somewhat 5-angled, crowned with a 15-denticulate white border: permanent pappusbristles none.

Lower Sonoran Zone, not common: Antelope Valley, Mohave Desert, Davidson; Rabbit Springs, Parish, no. 1264; Olancha, Lone Pine Creek, etc., Inyo Co.; eastward to Nebraska.

M. Torreyi Gray, and M. Fendleri Gray, are to be expected along our eastern borders. In the former the achenes are 5angled by as many salient ribs which are often almost wing-like: permanent bristles 2 to 8 and between them some minute teeth. In $M$. Fendleri the achenes are cylindric, bordered by a shallow crown with entire margin : persistent bristles none or only one.

5. M. Clevelandi Gray, Bot. Calif. i. 443 (1876).

Plant 2 to $4 \mathrm{dm}$. high, the stem diffusely branching throughout and bearing numerous loosely panicled heads of yellow flowers: herbage glabrous: radical leaves numerous, pinnatifid, the cauline scattered and more nearly entire: involucre 6 to $8 \mathrm{~mm}$. l:igh, few-flowered; its narrow bracts with purplish tips : ligules yellow : achenes oblong-linear, minutely striate-costate : outer pappus of one persistent bristle and a circle of white setulose teeth.

At middle and lower altitudes in the mountains: Rancho Viejo, Lower California, Brandegee; Ramona, San Diego Co., Brandegee; Santa Cruz Island, Brandegee; south side of San Jacinto Mt., Hall, nos. 1817, 2087; Cajon Pass, Parish, no. 4868; Jurupa Hills, near Riverside, Mrs. Wilder, no. 582; Santa Inez Mts., Dunn; Zaca Lake Forest Reserve, Santa Barbara Co., Miss Eastwood, no. 568; north to the base of Mt. Shasta (Sissons), Brandegee.

6. M. obtusa Benth., Pl. Hartweg. 321 (1849). M. parviflora Benth., l. c.

Habit, foliage, and involucre of $M$. Clevelandi, but often with 
traces of tomentum on the leaves and in their axils and the heads not so numerous: ligules white to pink, purple-veined on the back; throat of central flowers sometimes yellow : achenes obovateoblong, slightly narrowed at summit, angled by 5 prominent ribs : pappus-bristles all deciduous, leaving only a narrow searious entire rim to the achene (no outer circle of setulose teeth).

Mt. Pinos, Ventura Co., Hall, no. 6457; Santa Inez Mts., Santa Barbara Co., Brandegee; Mono Creek, Santa Barbara Co. (growing near M. Clevelandi), Hall, no. 7792; San Emigdio Cañon, Kern Co., Mrs. W. Jasper; thence north through the Coast Ranges to Humboldt Co., Marshall, Chesnut \& Drew, and through the Sierra Nevada Mts., to Plumas Co., Hall \& Babcock; no. 4433, and to Washoe Co., Nevada, Hall \& Chandler, no. 4557. Like M. Clevelandi, this species inhabits gravelly hillsides of the Upper Sonoran and Lower Transition zones. It is perhaps most abundant in the Yosemite district.

The type specimens of $M$. obtusa and $M$. parviflora have been compared at Kew by Professor W. L. Jepson, who informs me that he is unable to distinguish them by any technical character, although the type of the former has little flocks of wool on the leaves, these being absent from the type of $M$. parviflora. He rurther adds that neither of these types has the persistent setulose teeth erowning the achenes, so characteristic of M. Clevelendi.

7. M. foliosa Gray, Syn. Fl. i. pt. 2, 455 (1886). M. squalida Greene, Bull. Calif. Acad. ii. 152 (1886).

Erect, from an annual root, 1.5 to $6 \mathrm{dm}$. high, much branched above and very leafy nearly to the yellow-flowered heads: herbage glabrous: leaves mostly lanceolate, laciniate-pinnatifid, and 5 to $10 \mathrm{~cm}$. long, but the uppermost reduced: heads numerous, short-peduncled: involucre 10 to $12 \mathrm{~mm}$. high : achenes obscurely 5 -angled and 2 or 3 -striate between the angles: pappus wholly deciduous leaving neither bristles nor crown.

San Clemente Island, Apr., 1885, Nevin \& Lyon; Santa Barbara Island, May, 1901, Mrs. Trask; Santa Cruz Island, Jul. and Aug., 1886, Greene.-The last specimen eited is the type of Dr. Greene's M. squalida, a condensed form $2 \mathrm{dm}$. high; the leaves short and broad and with short lobes; the inflorescence more 
compact. It is strikingly different in appearance from typical $M$. folios $a$ but the characters separating it are all vegetative.

8. M. indecora Greene, Bull. Calif. Acad. ii. 152 (1886).

Stems from an annual root, sometimes diffuse and forming mats $15 \mathrm{~cm}$. or less thick, sometimes erect, slender, and even 4 ảm. high : leaves very thick and succulent, oblong-lanceolate, pinnately lobed, the lobes mostly obtuse: involucre 6 or $7 \mathrm{~mm}$. high, imbricated; inner bracts linear-lanceolate, green; outer ones said to be purplish: ligules short, greenish-yellow: achenes 5-angled and 2 or 3 -striate between the angles: pappus all deciduous.

Santa Cruz Island, Jul. and Aug., 1886, Greene; San Miguel Island, Sept., 1886, Greene; San Nicholas Island, Mrs. Trask; no. 8.

In the Herbarium of the California Academy of Sciences is a sheet (Acad. no. 49859) indicated as the type sheet of this species and mounted on it are several plants of very different habit but alike in technical characters. Some of these are only 1 $\mathrm{dm}$. high and widely branched; others have erect stems as much as $4 \mathrm{dm}$. high and are not at all matted. But another sheet in the California Academy Herbarium (Acad. no. 49858), although labeled by Professor Greene as the type of one of his unpublished species, is undoubtedly the one from which the description of $M$. indecora was drawn, the specimens being all matted and only 6 to $10 \mathrm{~cm}$. high, the largest forming a mat $17 \mathrm{~cm}$. in diameter. The label reads "Island of Santa Cruz, * * * Rocky islets and promontories, Edw. L. Greene, July and August, 1886." The San Miguel specimens are low and eompact. ${ }^{68}$ The species is best distinguished from $M$. folios $a$ by the size and character of its involueres.

9. M. incana (Nutt.) T. \& G., Fl. ii. 486 (1842). Malacomeris incanus Nutt., Trans. Am. Philos. Soe. ser. 2, vii. 435 (1841). Malacothrix succulenta Elmer, Bot. Gaz. xxxix. 44 (1905).

Stems several from a strong perennial root, somewhat woody below, commonly $3 \mathrm{dm}$. or less high: herbage covered with matted white wool when young, glabrate in age: leaves 5 to $10 \mathrm{~cm}$. long;

68 The two sheets mentioned above were examined before the recent San Francisco fire. It is hoped that they are among the types reseued by Miss Eastwood. 
oblanceolate in outline, tapering to the long narrow base, from entire to irregularly and shallowly lobed, or even pinnatifid with narrow lobes: peduncles exceeding the leaves, 1 or 2-cephalous: involucre 12 to $15 \mathrm{~mm}$. high; inner bracts equal, linear-oblong, obtuse; outer bracts short, imbricated, passing into scale-like bracts of the peduncle: ligules lemon-yellow: achenes oblong, truncate, 15 -striate, lightly pubescent or glabrous : pappus-bristles all deciduous.

San Diego, "on an island in the bay" (probably Coronados Islands), 1836, Nuttall; Santa Cruz Island, Aug., 1886, Greene; San Miguel Island, Sept., 1886, Greene (leaves, in one specimen, only $2 \mathrm{~cm}$. long); Santa Rosa Island, Brandegee; Santa Maria, Santa Barbara Co., Mrs. Ida M. Blochman; Pecho, San Luis Obispo Co., Mrs. R. W. Summers; Surf, Santa Barbara Co., ace. to Elmer (as M. succulenta).

10. M. saxatilis (Nutt.) T. \& G., Fl. ii. 486 (1842). Leucoseris saxatilis Nutt., Trans. Am. Philos. Soc. ser. 2, vii. 440 (1841).

Diffuse or decumbent from a suffrutescent base, 3 to $6 \mathrm{dm}$ (or more?) high: herbage succulent, minutely tomentose when young: leaves lanceolate to spatulate, mostly obtuse and entire but some of the lower ones toothed or pinnatifid: involucre 10 to $15 \mathrm{~mm}$. high; its bracts linear-attenuate, the outer ones very skort: ligules probably white: achenes 10 to 15 -costate, about 5 of the costae stronger than the others and rib-like, crowned with a minute denticulate white border: persistent pappus-bristles none.

"St. Barbara, on shelving rocks near the sea," ace. to Nuttall, who first collected it. I have seen specimens from Santa Barbara, Gaviota, and Santa Catalina Island.

Var. tenuifolia (Nutt.) Gray, Syn. Fl. i. pt. 2, 423 (1884). Leucosyris tenuifolia Nutt., Trans. Am. Philos. Soc. ser. 2, vii 440 (1841). Stems several, erect, 1 to $2.5 \mathrm{~m}$. high, scarcely suffrutescent: herbage glabrous, not succulent: leaves (or their lobes) acute; the lower often $10 \mathrm{~cm}$. long; the upper ones simple and linear to filiform, or pinnately parted into narrow lobes; those of the inflorescence much reduced: ligules white with a pink medial line.-Hillsides and cañons of the Upper Sonoran Zone, 
from Santa Cruz Island, Franceschi, and Santa Barbara, to San Jacinto and San Diego; also reported from Arizona. The extreme form with leaves or their lobes much elongated and nearly filiform comes from the Santa Ana Cañon, Orange Co., Hall, no. 6728.

Var. implicata (Eastw.) Hall, comb. nov. M. implicata Eastw., Proc. Calif. Acad. ser. 3 (bot.) i. 113 (1898). Stems woody, ciensely leafy up to the inflorescence: leaves irregularly bipinnately parted into filiform or narrowly linear segments : flowers white, pinkish-tinged.-San Nicholas Island, 1897 and 1901, Mrs. Trask; Santa Cruz Island, Brandegee; Santa Rosa Island, Branäegee, Miss Eastwood; San Miguel Island, Harford, Mrs. Trask: ii. H. Beck.

11. M. altissima Greene, Bull. Calif. Acad. i. 195 (1885), and Pitt. ii. 21 (1889).

Root only annual or biennial: stem solitary, herbaceous, erect, simple below, cymosely branching above, the whole plant about 1 or $2 \mathrm{~m}$. high : herbage minutely tomentose, glabrate : lower leaves lanceolate, acute or attenuate, usually with a few coarse teeth, 10 or $15 \mathrm{~cm}$. long; upper leaves linear-attenuate, entire : peduncles ascending or erect: involucre 10 to $12 \mathrm{~mm}$. high ; its bracts linearattenuate, the outer ones short: ligules white, often with a broad pink or rose-colored medial line: achenes and pappus as in $M$. saxatilis.

Upper Sonoran Zone: Tehachapi Station, Kern Co., Mrs. Curran; near Fort Tejon, Kern Co., Coville \& Funston, no. 1158; near Templeton, San Luis Obispo Co., Aug., 1907, Alfred Carling; in fields at Newhall and near Redlands, acc. to Parish.

A splendid series of specimens has been collected by Mr. Carling. All are strictly herbaceous throughout, with a single long taproot, and mostly with a single stem unbranched except above the middle; but a few have one to several lateral branches from near the base.

\section{CALYCOSERIS Gray.}

Much branched desert annuals, glabrous below, commonly dotted above with tack-shaped glands. Heads rather large, longpeduncled. Involucre many-flowered, of numerous narrow sea- 
rious-margined equal bracts and an outer series of much shorter lcose calyculate ones. Receptacle bearing capillary bristles among the flowers. Achenes 5-ribbed, narrowed above to a short beak which terminates in a shallow denticulate crown. Pappus copious, white, the bristles united at base and falling away in a ring.

Flowers yellow. 1. C. Parryi.

Flowers white, turning purplish: var. Californica of. 2. C. Wrightii.

\section{C. Parryi Gray, Bot. Mex. Bound. 106 (1859).}

Plant from a few $\mathrm{cm}$. to $3 \mathrm{dm}$. or more high: leaves linear and entire or pinnately parted into short linear lobes: glands of the infloreseence black: involucre 10 to $15 \mathrm{~mm}$. high: ligules bright yellow, 10 to $15 \mathrm{~mm}$. long: achenes $6 \mathrm{~mm}$. long including the slender beak, ending in a small apical cup, the ribs acute: pappus somewhat longer than the achene.

In the Desert Area from San Diego Co. to Utah: Jacumba, Cleveland, no 905; Palomar Mt., in the southern part of Riverside Co., Jepson and Hall; near Palm Cañon, Colorado Desert, Hall, no. 1857; north slope Cajon Pass and Ord Mts., Mohave Desert, Hall, nos. 6214, 6794; Morongo, Parish, no. 1214; Piute Creek, Mohave Desert, Wilson; Argus Mts., Coville \& Funston, no. 731; Bishop Creek, Inyo Co., Hall \& Chandler, no. 7239; Arizona, Wilson, Pringle, Toumey. The type locality given for this species, namely, "mountains east of Monterey, California," is certainly erroneous.

2. C. Wrightii Californica Brandegee, Zoe v. 155 (1903).

Habit, foliage, involucres, etc., as in C. Parryi: glands of the inflorescence pale: ligules white, the outer with pink-brown dots or streaks on back: achenes $6 \mathrm{~mm}$. long, stout and thick, acutely ribbed, the ribs rugulose and the beak short, ending in a rather conspicuous apical cup.

In sand near San Felipe, western borders of the Colorado Desert (with C. Parryi), Purpus; common on Chuckawalla Bench and in McCoy Wash, Colorado Desert, Hall, nos. 5872, 5966 (often $4 \mathrm{dm}$. high, growing among shrubs); Needles, Mohave Desert, Miss Warner. 


\section{GLYPTOPLEURA Eaton.}

Tufted desert annuals with leaves much exceeding the internodes and surrounding the numerous short-peduncled heads. Involucre of 7 to 12 equal linear-lanceolate bracts and some loose foliaceous ones at base. Receptacle naked. Achenes oblong; straight or incurved, obtusely 5-angled, each of the intervals marked by two rows of large tubercles, abruptly contracted above tr. a short stout 5-nerved beak, the base of which is surrounded by a narrow cup-like border: pappus-bristles bright white, in several series, the outer falling separately.

Ligules short, little exserted.

1. G. marginata.

Ligules 10 to $15 \mathrm{~mm}$. long, much exserted

2. G. setulosa.

1. G. marginata Eaton, Bot. King Exped. 207, t. 20 (1871).

Stem branching from the base, the whole plant not over $5 \mathrm{~cm}$. high excluding the long straight taproot: leaves obovate to spatulate-linear, commonly 3 or $4 \mathrm{~cm}$. long, sinuately lobed, the margin with a narrow scarious minutely toothed fringe; the upper bract-like leaves linear-lanceolate, commonly dilated at tip, the margins pectinate: involucre 10 or $12 \mathrm{~mm}$. high: ligules white, turning pink, scarcely exserted.

Lower Sonoran Zone: Mohave Desert, Parish, no. 1412; north to Oregon, Cusick, no. 2589; and S.E. Utah, Miss Eastwood.

2. G. setulosa Gray, Proc. Am. Acad. ix. 211 (1874).

Similar to $G$. marginata but the scarious margin of the leaves less conspicuous and often broken up into longer acicular white teeth; the upper bract-like leaves commonly linear and bearing tceth only at their dilated tips : ligules conspicuosly exserted, 10 to $15 \mathrm{~mm}$. long, white or yellow, sometimes changing to pink.

Mohave Desert (Lancaster, Barstow, Ludlow, Rabbit Springs: Hinckley) to S. Utah. Perhaps not distinet from G. marginata. Two specimens in the Parish Herbarium have been named by Dr. Gray as G. setulosa and G. marginata (Parish, nos. 1263, 1412, respectively) but they are exactly alike except that one has elongated yellow ligules, the other inconspicuous ligules. The color, however, is not a reliable character, elongated pure-white ligules sometimes changing to yellow in drying, as in Hall \& Chandler's 
no. 6870 from Fremonts Peak. The two species sometimes grow side by side.

\section{TARAXACUM Haller.}

Perennial acaulescent herbs with pinnatifid or toothed leaves all in a basal tuft and large heads of yellow flowers terminating usually simple and naked hollow scapes. Principal bracts of the involucre nearly equal, the outer much shorter and in several series. Receptacle flat, naked. Rays 5-toothed at the truncate summit. Achenes oblong or linear-fusiform, 4 or 5 -angled, 5 to 10-nerved, somewhat spinulose above, tapering into a slender beak which bears at its summit a copious pappus of unequal persistent bristles.

1. T. officinale Weber, Prim. Fl. Hols. 56 (1780). Leontodon T'araxacum L., Sp. Pl. 798 (1753). Taraxacum Dens-leonis Desf., Fl. Atlant. ii. 228 (1800). T. Taraxacum Karst., Deutsch. Fl. 1138 (1880-83). Dandelion.

Root thick and long, bitter : leaves oblong or spatulate in outline, irregularly dentate to sinuate-pinnatifid, from a few $\mathrm{cm}$. to nearly $3 \mathrm{dm}$. long, usually pubescent when young and somewhat succulent: inner bracts of the involucre linear or linear-lanceolate, acute, 10 to $15 \mathrm{~mm}$. long; outer ones similar but shorter, reflexed : flowers yellow : pappus brownish or white, maturing into a globose mass.

Occasional in lawns but not becoming naturalized. Introduced from Europe.

Var. lividum (Waldst. \& Kit.) Koch, Fl. Germ. 428 (1837). Leontodon lividus Waldst. \& Kit., Pl. Rar. Hung. ii. 120 (1805). Taraxacum lividum Heller, Bull. Torr. Club xxiv. 480 (1897). Outer involucral bracts broadly ovate to ovate-lanceolate.-Wet meadows at 1800 to $2500 \mathrm{~m}$., Little Bear Valley, Bear Valley, and Bluff Lake, all in the San Bernardino Mts., Parish; South Fork Meadows, San Bernardino Mts., Hall, no. 7512; boreal and aretic regions generally.

\section{SONCHUS L. SOW-THISTLE.}

Leafy-stemmed coarse succulent herbs, chiefly smooth and glaucous. Heads cymose or umbellate, swollen at base or jugshaped. Involucral bracts few, thin, with many shorter ones at 
base; these becoming eallous-thickened. Flowers yellow. Achenes obcompressed, ribbed, not beaked. Pappus copious, of cottonywhite exceedingly soft and fine hairs, mainly falling together.

Leaves runcinately or lyrately pinnatifid into broad lobes, or sometimes only serrate.

Leaf-auricles mostly acute: achenes longitudinally ribbed; the intervals transversely rugose.

1. $S$. oleraceus.

Leaf-auricles mostly rounded: achenes longitudinally ribbed; the intervals smooth 2. S. asper.

Leaves pinnately parted into narrow lobes. 3. S. tenerrimus.

1. S. oleraceus L., Sp. Pl. 794 (1753). Сommon Sow-thistle.

A nearly simple-stemmed annual, 3 to $30 \mathrm{dm}$. high: leaves with the terminal segment commonly iarge and triangular, dentic, ulate or toothed; lower leaves petioled; uppermost sessile and commonly lanceolate: peduncles occasionally glandular-hirsute: involucre 8 to $16 \mathrm{~mm}$. high: achenes longitudinally ribbed and transversely rugose.

Naturalized European weed: in waste places, flowering at all seasons.

2. S. asper (L.) Hill, Herb. Brit. i. 47 (1769). S. oleraceus asper L., Sp. Pl. 794 (1753). Prickly Sow-thistle.

Very similar to the preceding, but the leaves sometimes undivided and commonly clasping by an auricled base, the auricles rounded; margins spinulose-denticulate: peduncles often conspicuously hirsute with spreading gland-tipped hairs: achenes flat; margined with a narrow wing and longitudinally ribbed; intervals between the ribs smooth, but the ribs as well as the marginal wing rugulose or serrulate.

Naturalized European weed: very common.

3. S. tenerrimus L., Sp. Pl. 794 (1753).

Much branched, 3 to $10 \mathrm{dm}$. or less high, very leafy up to the short-pedunculate heads : herbage glabrous : leaves oblong in outline, the linear or narrowly lanceolate lobes commonly cuspidate and either spinulosely denticulate or entire: achenes longitudinally striate and transversely rugose.

Native of Europe; introduced at San Diego, and on San Clemente, Santa Catalina, and San Nicholas islands. Mr. Bran- 
degee reports it as abundant and appearing as though native on the Todos Santos, Natividad, Cedros, San Martin, and Guadalupe islands, all off the coast of Lower California, and at San Jorge, on the mainland.

\section{LACTUCA Tourn. LetTuce.}

Tall leafy-stemmed herbs with panicled heads of (in our species) yellow flowers. Leaves alternate. Involucre cylindrical or in fruit conical, its bracts imbricated in 2 or more series of unequal lengths. Rays 5-toothed at summit. Achenes obcompressed, i.e., flattened parallel to the bracts, 1 to 5-nerved on each face, contracted into a beak, which bears at its dilated summit a copious very soft and white or brown eapillary pappus, the hairs of which fall separately.

1. L. Scariola var. integrata Gren. \& Godr., Fl. France ii. 320 (1850) ; Dewey, Rhodora vii. 11 (1905). Prickly Lettuce.

Plant 6 to $18 \mathrm{dm}$. high, branching above into an open panicle, glabrous throughout or hirsute or prickly below : leaves oblong or oblong-lanceolate, sessile or sagittate-clasping, with a row of soft prickles on the midrib and along the margins : heads numerous, 6 to 14-flowered: involucre 10 to $14 \mathrm{~mm}$. high; its outer bracts much shorter than the inner: rays cream-yellow changing to blue: achenes light brownish gray, narrowly obovate, about as long as the filiform beak, striate, margined: pappus white.

An introduced European weed which, during the last decade, has become exceedingly abundant on waste lots and along roadsides near Los Angeles, San Bernardino, etc. Typical L. Scariola L., which has apparently not yet appeared in Southern California, has runcinate or pinnately lobed leaves.

L. Sativa L., the common Lettuce, may be found as an escape from gardens. It has broad and tender root-leaves and cordateclasping stem-leaves.

L. Ludoviciana (Nutt.) DC., of the middle states, may occur as an immigrant. It has black achenes, lightly 1-nerved on each face : involucre 2.5 to $3 \mathrm{~cm}$. high. 


\section{LYGODESMIA Don.}

Herbs, mostly with glabrous rush-like tough stems and narrow leaves. Heads scattered or terminal, erect, 3 to 12 -flowered. Flowers pink or rose-color. Achenes slender, terete, obscurely striate or angled, truncate at each end. Pappus of numerous unequal white or whitish capillary bristles, not plumose.

1. L. exigua Gray, Proc. Am. Acad. ix. 217 (1874). Prenanthes exigua Gray, Pl. Wright. ii. 105 (1853).

A diffusely branched glabrous annual, 1 to 3 (or 5) dm. high: leaves mostly basal, oblanceolate, entire or dentate, or pinnatifid with sharp lobes, 2 or $3 \mathrm{~cm}$. long, the upper reduced to scale-like bracts: heads on slender peduncles: involucre $5 \mathrm{~mm}$. high; its principal bracts about four, linear-oblong, acute; the calyculate ones few and very short: achenes scarcely longer than the copious white pappus-bristles.

Rabbit Springs, Mohave Desert, Parish, where it is probably not uncommon; Paloverde Valley, Riverside Co., near the Colorado River, Hall, no. 5918; Colorado Desert, Stephens; Lower California, Brandegee; Inyo Co., in the Arguis Mts., Purpus, no. 5319 ; Panamint Mts. and Owens Valley, acc. to Coville; thence to Utah and New Mexico, ace. to Gray.

L. SPINOSA Nutt., a spinescent perennial with matted-woolly base has been reported from the eastern borders of California, but has probably not been collected within our limits. It is not rare in Inyo Co.

\section{TROXIMON Nutt.}

Perennial herbs with strong and often deep taproots, or annuals. Stems nearly naked and scape-like, bearing single large heads. Leaves in a radical tuft or a few scattered on the stem below, elongated. Bracts of the campanulate involucre imbrieated, the outer ovate or narrower; the inner ones linear or lanceolate. Flowers, in our species, yellow. Achenes terete, oblong, or fusiform, 10-ribbed, narrowed above, in all of our species prolonged into a slender or filiform beak. Pappus-bristles fine, copious, inserted on the dilated apex of the beak. Achenes in 
fruit expanding and forming a globose head, the bracts of the involucre then reflexed.

The reinstatement of the genus Agoseris Raf. (1817) has been proposed for those species of Troximon in which the achenes are beaked. But the two groups are best received into one genus, being connected by the thick-beaked T. glaucum. Troximon was first used as a generic name by Gaertner (1791), but since his genus is not sustained, we may properly write Troximon Nutt. (1813) as the name of the present group.

Perennials: involucre 2.5 to $5 \mathrm{~cm}$. high.

Achenes abruptly beaked from a broad truncate summit....1. T. retrorsum.

Achenes tapering into the beak. 2. T. plebeium. Annual: involucre 1.2 to $1.8 \mathrm{~cm}$. high. 3. T. heterophyllum.

1. T. retrorsum (Benth.) Gray, Proc. Am. Acad. ix. 216 (1874). Macrorhynchus retrorsus Benth., Pl. Hartweg. 320 (1849). M. angustifolius Kell., Proc. Calif. Acad. v. 47 (1873)? Agoseris retrorsa Greene, Pitt. ii. 178 (1891).

Scapes 1.5 to even $4 \mathrm{dm}$. high, from a stout perennial taproot: herbage woolly-pubescent when young, the wool deciduous in age: leaves commonly 1 to $2.5 \mathrm{dm}$. long, sometimes as long as the peduncles, pinnately parted into narrowly linear or lanceolate mostly retrorse segments, the rachis linear and the lobes more or less remote: outer involucral bracts broadly oblong and merely acute; inner bracts linear and narrowly acuminate, 2.5 to 4 or 5 $\mathrm{cm}$. long, about equalling the pappus : ligules short: achenes 5 to $6 \mathrm{~mm}$. long, passing abruptly into the slender (18 to $20 \mathrm{~mm}$. long) beak: pappus soft and white.

On open foothills and in the lower part of the pine belt, usually in loose gravelly soil, from the Cuyamaca Mts., San Diego Co. (and Lower California?), north to Oregon. Not common in Southern California.

2. T. plebeium Greene, Pitt. ii. 79 (1890). Agoseris plebeia Greene, l. c. 178 (1891).

Scapes stout, 2 to $6 \mathrm{dm}$. high, much exceeding the leaves: herbage short-hirsute or lightly tomentose, glabrate: leaves 1 to $2 \mathrm{dm}$. long, oblong or spatulate in outline, dentate to pinnately parted into linear usually ascending lobes: involucre broad, 2.5 
to $3 \mathrm{~cm}$. high, its broad outer bracts well imbricated and with rather persistent traces of white wool: ligules shorter than the involucre: achenes 4 or $5 \mathrm{~mm}$. long, tapering into a filiform beak 12 to $15 \mathrm{~mm}$. long: pappus usually bright white.

Talmadge's Mill, in the San Bernardino Mts., at an altitude of 1500 m., Parish, no. 3051; Laguna, San Diego Co., Cleveland: no. 435 ; Cuyamaca Mts., San Diego Co., Brandegee; eastern base San Jacinto Mts., Hall; Santa Ana and San Gabriel Mts., ace. to Abrams; Casitas Pass, Ventura Co., Hall, nos. 3205a, 3218; Mono Flat, Santa Barbara Co., Hall, no. 7790; and north. The Southern California specimens usually have leaves with broad and merely acute terminal lobes; in the region of San Franciseo Bay the leaves are much more slender and the terminal lobe is acuminate; my number $3205 \mathrm{a}$ is exactly intermediate between these two forms.

3. T. heterophyllum Greene, Bull. Torr. Club x. 88 (1883). T. Chilense Gray, Proc. Am. Acad. ix. 216 (1874); not Macrorhynchus Chilense Less.

Scapes slender, .5 to $4 \mathrm{dm}$. high, from an annual root, often numerous: leaves linear to oblong or spatulate, entire or denticulate to sinuate-pinnatifid, sparingly villous-pubescent or glabrous: involucral bracts lanceolate-acuminate; the inner ones glabrous, 1.2 to $1.8 \mathrm{~cm}$. long: ligules inconspicuous (except in var. Californicum), seldom exceeding the involucre: achenes 4 $\mathrm{mm}$. or less long, variable, as indicated below; the outer ones glabrous to villous: pappus whitish, commonly shorter than the beak of the achene.

SyNopsis of VARIETIES AND Forms OF T. HETEROPHyLKUM.

Ligules inconspicuous, about as long as the involucre.

Outer achenes with straight ribs f. normale.

Outer achenes with sinuate ribs f. kymapleurum.

Outer achenes enlarged, not ribbed f. cryptopleurum.

Ligules conspicuous, much exceeding the involucre.

Outer achenes with straight ribs ..var. Californicum f. idiale.

Outer achenes with sinuate ribs var. Californicum f. crenulatum.

Outer achenes enlarged, not ribbed var. Californicum f. turgidum.

f. normale (Piper) Hall, comb. nov. T. heterophyllum Greene, 1. c. Agoseris heterophylla Greene, Pitt. ii. 178 (1891). A. heterophylla subsp. normalis Piper, Contr. U. S. Nat. Herb. xi. 544 
(1906). Achenes with straight ribs, or the inner ones smoothish or merely costate.-Palomar, San Jacinto, and San Bernardino Mts., north to British Columbia, and on the islands from Guadalupe at least to Santa Cruz.

f. kymapleurum Greene, Bull. Torr. Club x. 88 (1883), as var. Macrorhynchus heterophyllus Nutt., Trans. Am. Philos. Soc. ser. 2, vii. 430 (1841). Kymapleura heterophylla Nutt., 1. c. errat 455. Agoseris heterophylla kymapleura Greene, Pitt. ii. 179 (1891). Ribs of the outer, and sometimes also the inner achenes corky-thickened and beautifully sinuate or undulate.-A common form, usually with the species, but not yet detected in Southern California. It will be noted that this is the form first named and described and therefore represents the taxonomic type of the species, while f. normale evidently represents the morphologic type.

f. cryptopleurum Greene, Bull. Torr. Club x. 88 (1883), as var. Agoseris heterophylla var. cryptopleura Greene, Pitt. ii. 179 (1891). A. heterophylla Californica Piper, Contr. U. S. Nat Herb. xi. 544 (1906); not Cryptopleura Californica Nutt. Outer achenes or some of them much inflated and inconspicuously striate, not at all ribbed or winged.-Also with the species in middle California and northward but not yet seen within our borders.

Var. Californicum (Nutt.) Hall, comb. nov. Cryptopleura Californica Nutt., Trans. Am. Philos. Soc. ser. 2, vii. 431 (1841), characters extended. Plant usually larger and coarser than in typical T. heterophyllum; seapes 15 to $45 \mathrm{~cm}$. high: ligules conspicuous, about $1 \mathrm{~cm}$. long, much exceeding the involucre: achenes exhibiting a series of variations exactly parallel with those of the species.

Var. Californicum f. idiale Hall, form. nov. Achenes with straight ribs or the inner ones with straight striae.-Near Goshen, Tulare Co., Brandegee, as formerly represented in the Herbarium of the California Academy of Sciences; New York Ravine, El Dorado Co., Mrs. Brandegee (Herb. Univ. Calif. no. 88020); Simpsons, El Dorado Co., Mrs. Brandegee (Herb. Univ. Calif. no. 88021). Several other collections are intermediate between this morphologically typical form and the next. 
Var. Californicum f. crenulatum Hall, nom. nov. Troximon elatum Greene, Pitt. i. 71 (1887) ; not Stylopappus elatus Nutt. Agoseris major Jepson, Pitt. ii. 179 (Sept. 15, 1891), and Bull. Torr. Club xviii. 325 (Nov., 1891). Ribs of at least the outer achenes corky-thickened and conspicuously undulate, rendering the body obtuse or truncate at summit.-Plains of the lower Sacramento River, acc. to Greene; Willow Branch, Marysville Buttes, Apr. 20, 1891, Jepson; Paso Robles, San Luis Obispo Co., Barber, no. A 19 ; same locality, May, 1907, Benj. Cobb, in part; Ojai Valley, Ventura Co., Hall, no. 3198; Santa Inez Mts., 1888, Brandegee; Zaca Lake Forest Reserve, Santa Barbara Co., Miss Eastwood, no. 736, in part; Tehachapi, Mrs. Brandegee (Herb. Univ. Calif. no. 88022).

Var. Californicum f. turgidum Hall, nom. nov. Cryptopleura Californica Nutt., Trans. Am. Philos. Soc. ser. 2, vii. 431 (1841). Outer and sometimes all of the achenes more or less irflated, often even $2 \mathrm{~mm}$. thick and truncate at apex, sometimes less inflated and tapering to the beak, inconspicuously striate or their nerves quite obsolete._- "Near Santa Barbara," acc. to Nuttall, who obtained only depauperate specimens ("about three to four inches high',) ; near Santa Barbara, 1888, Brandegee; grassy valley near the coast of San Luis Obispo Co., Apr. 23, 1886, Mrs. R. W. Summers, in part (distributed as Agoseris grandiflora); Cuddy Valley, Mt. Pinos, Ventura Co., Hall, no. 6421; Santa Inez Mts., 1888, Brandegee (some specimens approaching var. Californicum f. idiale); Paso Robles, May, 1907, Benj. Cobb, in part; Zaca Lake Forest Reserve, Santa Barbara Co., Miss Eastwood, no. 736, in part; Tehachapi, Mrs. Brandegee (Herb. Univ. Calif. no. 88023) ; Simpsons, El Dorado Co., Mrs. Brandegee (Herb. Univ. Calif. no. 88024).

The above arrangement of the forms of this aggregate species is intended to express the idea that they represent two lines of descent, the one being distinguished by short ligules, the other by elongated ligules. In each of these series we have three similar forms, differing only in their achenes, and each form in the one series is strictly analogous to a corresponding form in the other series.

The length of the ligule in this species furnishes us with a 
fairly constant character for separating the two varieties. So far as noted it does not vary beyond reasonable limits, so that there is never any question as to the variety to which any particular specimen belongs. But in all other characters-habit, size, pubescence, involucre, etc.,- the two varieties exhibit the same forms, and since they both run into strictly parallel strains as regards their achenes they cannot be considered as distinct species.

A splendid series of several hundred specimens of var. Californicum, recently gathered near San Luis Obispo by Mr. Benj. Cobb, indicates that the achenial characters, although remarkable in their extremes, are of comparatively trivial importance. The central achenes are mostly traversed by straight ribs, or costae In the marginal achenes these ribs vary from slightly undulate to strongly and closely crinkled, so that the surface of the achene appears as though honey-combed (f. crenulatum). On other plants, gathered at the same station, the marginal achenes vary from slightly swollen and spindle-shaped, with the costae still evident, to strongly swollen and balloon-like, all traces of costae or ribs having been obliterated through the stretching of the surface (f. turgidum). The same variation, but to a more limited extent, is observable in collections from other localities.

\section{CREPIS L.}

Herbaceous annuals, biennials, and perennials, similar to Hieracium but distinguished from that genus by the shape of the achenes and by the pappus. Involucre cylindric or campanulate; its principal bracts in a single row, equal, with more or less thickened midribs; the outer calyculate ones much smaller or wanting. Flowers yellow. Achenes narrowed toward the summit and sometimes also at base, 10 to 30 -ribbed. Pappus copious, white and soft.

Introduced species: root annual or biennial.

Involuere 7 to $9 \mathrm{~mm}$. high: achenes 10 -striate. 1. C. virens.

Involucre 9 to $12 \mathrm{~mm}$. high: achenes 13-striate 2. C. biennis. Native species: root perennial.

Involucre 5 to 10 -flowered, its principal bracts only 5 to 8 .

3. C. acuminata.

Involucre 10 to 30 -flowered, its principal bracts 8 to 24 .

4. C. occidentalis. 
1. C. virens L., Sp. Pl. ed. 2, 1134 (1763). Sмоотн HawksBEARD.

Annual or biennial, 3 to $7 \mathrm{dm}$. high: stem slender, simple below, paniculate above: herbage green and glabrous, or somewhat hirsute below: radical leaves numerous, oblanceolate, toothed to pinnatifid, narrowed at base into a petiole; cauline leaves lanceolate, with sessile subsagittate base; uppermost leaves commonly linear or subulate and entire: heads many: involucre 7 to $9 \mathrm{~mm}$. high, somewhat ealyculate; its bracts linear, acuminate, often pubescent: achenes linear-oblong, narrowed equally to each end, 10-ribbed.

On Big Rock Creek, desert slopes of the San Gabriel Mts., Jul. 6, 1896, Davidson. Introduced from Europe.

2. C. biennis L., Sp. Pl. 807 (1753). Rough Hawksbeard.

Biennial, branched above, 5 to $12 \mathrm{dm}$. high: herbage pubescent, often hirsutely so, especially above: lower leaves oblong or spatulate, runcinate-pinnatifid or sometimes merely dentate, narrowed at base into a petiole; upper cauline leaves sessile by a sagittate-dentate base: involucre 9 to $12 \mathrm{~mm}$. high: achenes oblong, somewhat narrowed above, 13-ribbed.

Streets of Pasadena, acc. to McClatchie. Introduced from Europe.

3. C. acuminata Nutt., Trans. Am. Philos. Soc. ser. 2, vii. 437 (1841).

Perennial, slender, 3 to 8 or $9 \mathrm{dm}$. high, eymosely branched above: herbage cinereously puberulent but the inflorescence nearly glabrous : lower leaves 15 to $25 \mathrm{~cm}$. long, broadly lanceolate in outline, pinnatifid with narrow spreading or retrorse lobes, attenuate below into a petiole and above into a tail-like prolongation $8 \mathrm{~cm}$. or less long: involuere narrow, 10 to $12 \mathrm{~mm}$. high; minute outer bracts eanescent; inner bracts 5 to 8 , bright green, glabrate: flowers 5 to 10 : achenes fusiform, somewhat narrowed at summit.

On dry slopes in open forests of the Transition Zone: San Bernardino Mts., at Bear Valley, Parish, no. 1460, and Upper Santa Ana Cañon, Hall, no. 7538; Frazier and Alamo Mts., Ventura Co., Hall, nos. 6596, 6702; Mt. Pinos, in Kern Co., Hall, 
no. 6384, and Jun., 1904, Grinnell; Tehachapi Mts., Kern Co.; Hasse \& Davidson, no. 1737 ; thence north and east.

4. C. occidentalis Nutt., Journ. Acad. Philad. vii. 29 (1834). Gray Hawksbieard.

Stems stout, usually several from the strong perennial root, branching above, the whole plant 1 to $2 \mathrm{dm}$. high : herbage tomentose (the tomentum sometimes with a tendency to fall in age) and often glandular-hirsute above, especially on the peduncles: leaves thickish, runcinately toothed or deeply pinnatifid into linear or lanceolate lobes, the uppermost portion entire, acuminate : involucre 10 to 30 -flowered, 12 to $15 \mathrm{~mm}$. high, calyculate, its 8 to 24 bracts oblong-lanceolate: achenes brown, fusiform, 10 to 18 costate, 8 or $9 \mathrm{~mm}$. long.

On dry forested slopes of the Transition Zone (rarely in the Upper Sonoran): Bear Valley, San Bernardino Mts., Parish, no. 1459 ; Pinos, Frazier, and Alamo Mts., Ventura Co., Hall, nos 6556 , 6595, 6703, respectively; north to Washington, east to Nebraska, etc.

Var. subacaulis Kell., Proc. Calif. Acad. v. 50 (1873). C. subacaulis Coville, Contr. U. S. Nat. Herb. iii. 562 (1896). Herbage (especially the peduncles, petioles, and midribs of the leaves) usually hirsute with spreading glandless hairs; leaves deeply pinnatifid or bipinnatifid.-Bear Valley, San Bernardino Mts., Parish, acc. to Coville; northern Sierra Nevadas.

Two distinct forms (in addition to the named variety) may be segregated from $C$. occidentalis as above characterized; the one, represented by such specimens as my nos. 6595 and 6703 , being merely canescent-tomentose; the other, represented by $\mathrm{Mr}$. Parish's no. 1459 and my no. 6556, having bristly gland-tipped black hairs on the inflorescence, in addition to the tomentum. The non-hirsute form sometimes exhibits a few sessile yellow glands on the involucral bracts. The var. subacaulis differs from the species mainly in the absence of glands on the spreading hairs when these are present, but some specimens of both the species and the variety are destitute of spreading hairs. 


\section{HIERACIUM L. HAWKWEED.}

Perennial herbs, ours rough-hairy, with entire or dentate leaves and small or middle-sized heads in a panicle. Involucre cylindric or eampanulate, its main bracts in 1 to 3 ranks with shorter ones at base, destitute of thickened midribs. Achenes linear, not at all narrowed above, striately ribbed. Pappus a single row of fragile eapillary bristles.

One of the largest of plant genera, a majority of the species European. Several of our species are but very imperfectly understood. It seems quite probable that further investigation will prove our nos. 3 and 5 , together with $H$. Brandegei, to be only forms of $H$. argutum.

Flowers white: stems tall.

1. H. albiflorum.

Flowers yellow.

Stems leafy.

Pappus rufous or brown: leaves entire

2. H. horridum.

Pappus nearly white: leaves mostly dentate.

Inflorescence leafy: peduncles and involucres with light-colored stipitate glands, or smooth.

3. H. Parishii.

Inflorescence merely bracteate: peduncles and involucres with black stipitate glands

4. H. argutum.

Stems nearly naked except at base: involucre and peduncles roughened by stipitate glands.

5. H. Grinnellii.

1. H. albiflorum Hook., Fl. Bor. Am. i. 298 (1834).

Five to $9 \mathrm{dm}$. high: stems leafy below, nearly naked above, ending in a panicle of white-flowered heads: herbage thickly beset below with tawny bristly hairs; glabrous above except for a minute glandular pubescence and sometimes a few soft hairs on the inflorescence: lower leaves oblong, narrowed at base to a winged petiole, 10 to $15 \mathrm{~cm}$. long, 2 to $4 \mathrm{~cm}$. broad, from entire to saliently repand-dentate; upper leaves oblanceolate to linear, those of the inflorescence linear-subulate: involucre about $10 \mathrm{~mm}$. high; its bracts linear-attenuate: pappus dull white.

In open pine forests of the Transition Zone, from the San Jacinto Mts. north throughout the state and also in the Rocky IMts.

2. H. horridum Fries., Epic. Hier. 154 (1862). H. Breweri Gray, Proc. Am. Acad. vi. 553 (1865).

Plant 1 to $3 \mathrm{dm}$. high, with commonly numerous stems from 
stout horizontal roots: herbage pubescent with long brown or whitish shaggy hairs: leaves oblanceolate or ligulate, obtuse; the lower $10 \mathrm{~cm}$. or less long by 10 to $15 \mathrm{~mm}$. wide, tapering to broadly margined petioles; the upper ones somewhat smaller, sessile: panicle rather close: involucre 6 or $7 \mathrm{~mm}$. high; its bracts narrowly lanceolate, acute: ligules bright yellow: pappus fuscous.

Always among rocks or in decomposed granite: Upper Transition and Canadian zones (altitude 1800 to $2500 \mathrm{~m}$.) in the San Jacinto and San Bernardino Mts., and on Mt. Pinos, Ventura Co.; to be expected in the San Gabriel Range; northward throughout the Sierra Nevadas. In Sierran specimens the color of the crinite pubescence rurs through all shades from rich reddish-brown to pure white.

3. H. Parishii Gray, Proc. Am. Acad. xix. 67 (1883).

Plant 3 to $6 \mathrm{dm}$. high, stems several, apparently from stout horizontal rootstocks, leafy up into the narrowly oblong panicle: pubescence shaggy-hirsute on lower leaves and basal portion of stem, glandular hairs of the inflorescence light-colored or none: lower leaves oblong to narrowly lanceolate, tapering to margined petioles, remotely but saliently toothed on the margins, 8 to 20 $\mathrm{cm}$. long, $12 \mathrm{~mm}$. or more wide; upper ones narrow, sessile and entire, $5 \mathrm{~cm}$. or more long: peduncles shorter than or slightly exceeding the heads: involucral bracts linear-subulate: flowers yellow : pappus nearly white.

Foothills of the San Bernardino and San Gabriel Mts. in the Upper Sonoran Zone.

Dr. Gray describes this species as having "no glandular hairs or stipitate glands: **** involucre pale, granulose-pubervlent." Mr. Parish has collected it a number of times and writes: "All specimens collected by me came from a limited s\};ace on some cliffs at about $3000 \mathrm{ft}$. alt. in Waterman Cañon." Now, while these specimens are mostly only viscid-glandular in the inflorescence, some of them have conspicuous but lightcolored stipitate glands, thus exhibiting an interesting variation in this character. Mr. Parish further writes that the species must have been founded on his no. 1132, of Sept. 25, 1881, this being the only number of it collected previous to the publication of the species. 
4. H. argutum Nutt., Trans. Am. Philos. Soc. ser. 2, vii. 447 (1841).

Plant 3 to $10 \mathrm{dm}$. high, leafy up to the inflorescence: herbage shaggy with brown hairs below, the upper part of the stem and the inflorescence blackish-green and glandular: leaves oblong to lanceolate, acute, remotely but saliently dentate; the lower ones 7 to $20 \mathrm{~cm}$. long, 1 to $4 \mathrm{~cm}$. wide; upper cauline leaves sessile and narrow : ligules probably yellow : pappus gray.

A little-known species first collected in the hills back of Santa

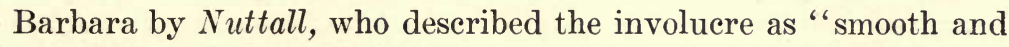
blackish-green." My description is drawn from the following specimens, all of which have a densely glandular inflorescence: Santa Cruz Island, Aug., 1886, Greene; Santa Lucia Mts., Aug., 1885, Plaskett; Santa Rosa Island, Jun., 1888, Brandegee.

5. H. Grinnellii Eastwood, Bull. Torr. Club xxxii. 217 (1905).

Slender, 2 to $6 \mathrm{dm}$. high, with leaves mainly in a basal cluster : herbage densely clothed below with long white or brown woolly hairs; upper part of stem granular-puberulent; peduncles and involucres beset with numerous short-stipitate glands: basal leaves oblanceolate, tapering to a broad petiole, mostly repanddenticulate and acute, a few entire and obtuse, 4 to $12 \mathrm{~cm}$. long, 1 or $2 \mathrm{~cm}$. wide; the cauline few, linear-acuminate, sessile, entire or nearly so: panicle open, the branches few and widely spreading: peduncles 1 to $3 \mathrm{~cm}$. long: involucre 8 to $10 \mathrm{~mm}$. high; its bracts linear-attenuate: ligules yellow: pappus white or with a yellowish tinge.

Arroyo Seco, near Pasadena, Dec., 1903, and Jul., 1904,Grinnell; Malibu Creek, Santa Monica Mts., Aug. 5, 1898, Barber; Fish Creek, San Bernardino Mts., J. and H. W. Grinnell, no. 246 (less pubescent above).

H. BRANDEGEI Greene is known only from the original collection, Santa Lucia Mts. (north of our district), 1885, Brandegee; but is to be expected further south. It is much like H. Grinnellii, but may be distinguished by its short and broad $(5 \mathrm{~cm}$. or less long) obtuse entire leaves. 


\section{INDEX.}

\begin{tabular}{|c|c|c|c|}
\hline & PAGE & & PAGE \\
\hline Acamptopappus & 41 & 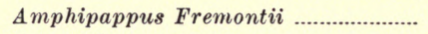 & 36 \\
\hline microcephalus ..... & 53 & 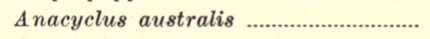 & 213 \\
\hline Shockleyi & 41 & Anaphalis margaritacea .............115, & 112 \\
\hline sphaerocephalus & 11 & Ancistrocarphus filagineus .................... & 104 \\
\hline Acarphaea artemisiaefolia .................... & 199 & Anisocoma & 253 \\
\hline Achillea ............................. & 211 & acaulis & 253 \\
\hline Californica & 211 & Antennaria & 108 \\
\hline lanulosa ................... & 212 & dimorpha & 109 \\
\hline Millefolium .......... & 211 & marginata & 110 \\
\hline f. Californica & 211 & media & 9 \\
\hline 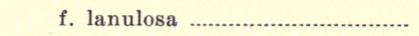 & 212 & speciosa & 110 \\
\hline Achyrachaena & 160 & Anthemideae & 210 \\
\hline mollis ............ & 161 & Anthemis ....... & 210 \\
\hline Acknowledgments ........ & 7 . & Cotula & 211 \\
\hline Acourtia microcephala & 245 & Aplopappus (see Haplopappus) & \\
\hline Actinella biennis .......... & 204 & 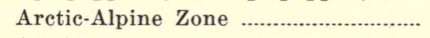 & 9 \\
\hline Cooperi ……................ & 203 & Aretium & 236 \\
\hline Actinolepis lanosa .... & 181 & Lappa .... & 236 \\
\hline Lemmoni ..................... & 177 & Arnica & 222 \\
\hline multicaulis & 180 & Bernardina & 10 \\
\hline Pringlei ..... & 181 & cordifolia ................ & 222 \\
\hline Wallacei ......... & 182 & Aromia tenuifolia ... & 187 \\
\hline Agarista calliopsidea & 141 & Arrow-weed ….......... & 101 \\
\hline Ageratum lineare ....... & 179 & Artemisia ................... & 297 \\
\hline Agoseris ......................... & 276 & biennis ........ & 217 \\
\hline heterophylla .. & 277 & Californica & 10 \\
\hline var. Californica ... & 278 & desertorum ........... & 215 \\
\hline var. Cryptopleura & 278 & dracunculoides & 216 \\
\hline var. kymapleura ... & 278 & 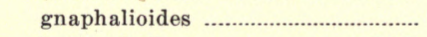 & 217 \\
\hline subsp. normalis . & 277 & heterophylla …........................... & 218 \\
\hline major & 279 & Kennedyi ................. & 218 \\
\hline plebeia ..... & 276 & Ludoviciana .......... & 217 \\
\hline retrorsa & 276 & matricarioides ........... & 212 \\
\hline 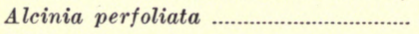 & 144 & 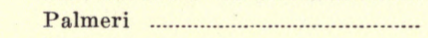 & 220 \\
\hline 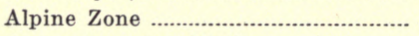 & 9 & 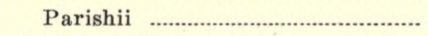 & 220 \\
\hline Amauria rotundifolia .... & 166 & 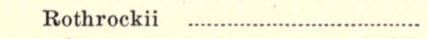 & 297 \\
\hline Amblyopappus …..................... & 187 & spinescens & 11 \\
\hline pusillus ............ & 187 & Suksdorfii & 218 \\
\hline Ambrosia ............. & 119 & tridentata & 297 \\
\hline acanthicarpa ...... & 121 & var. angustifolia & 219 \\
\hline psilostachya .. & 119 & trifida & 219 \\
\hline pumila ............. & 119 & tripartita & 219 \\
\hline Ambrosiaceae. & 4 & Artichoke ... & 242 \\
\hline Ambrosieae ................. & 116 & Aster .................. & 76 \\
\hline 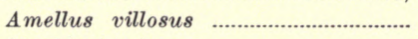 & 113 & adscendens & 82 \\
\hline Amphiachyris & 36 & aestivus ............ & 81 \\
\hline Fremontii & 36 & Andersonii & 83 \\
\hline
\end{tabular}




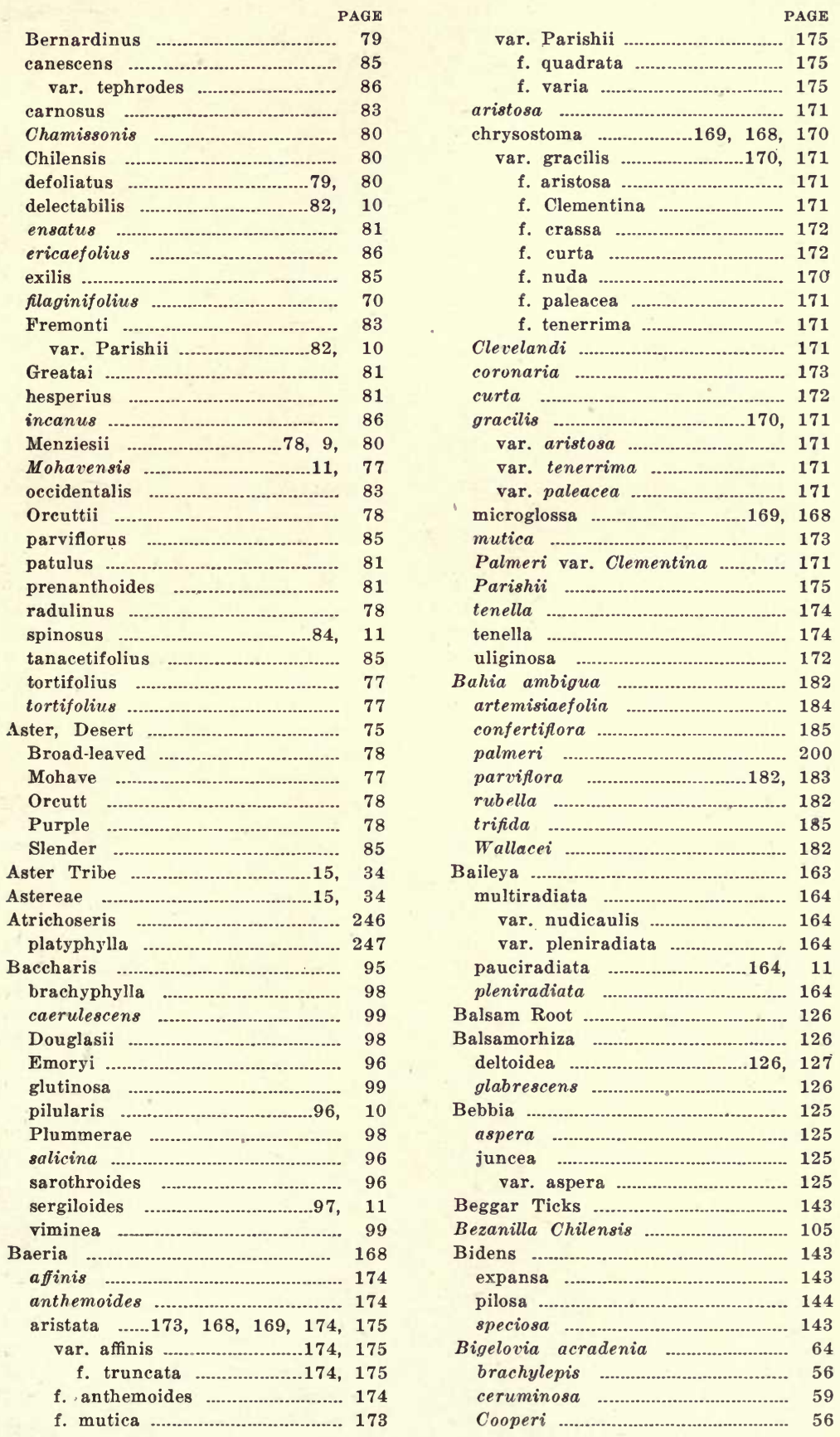




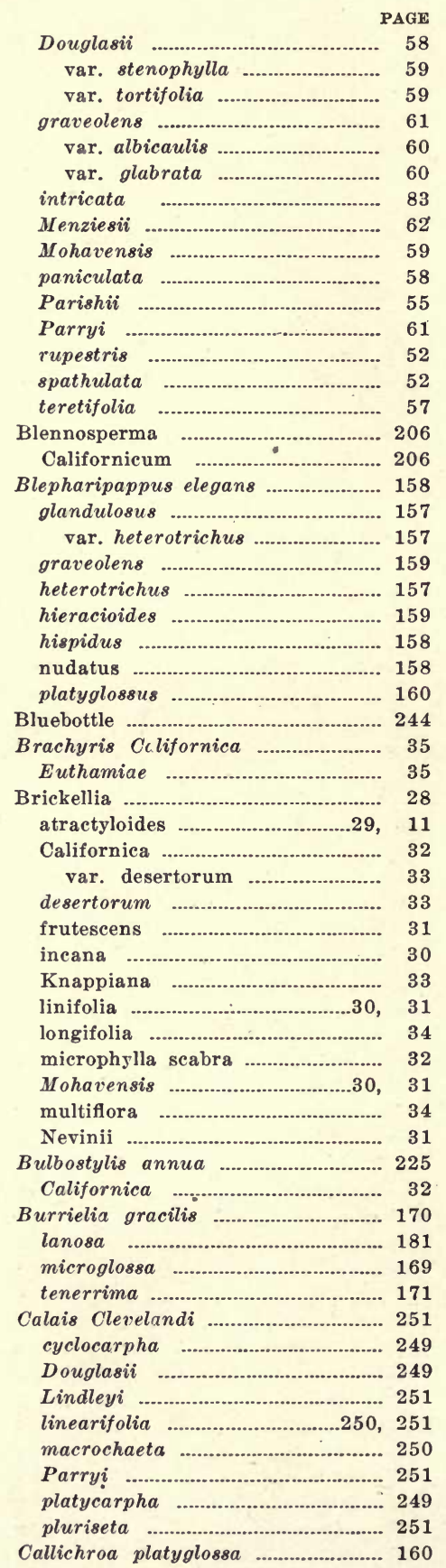

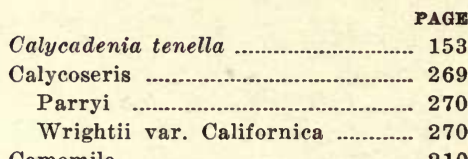

Camomile ............................................. 210

Canadian Zone .............................. $9, \quad 10$

Cardoon .............................................. 242

Carduaceae …....................................... 4

Carduus .............................................. 236

Bernardinus ................................. 241

Californicus ................................. 240

var. Bernardinus ...................... 241

candidissimus ............................... 240

Drummondii .................................... 238

var. acaulescens ........................ 238

edulis ............................................ 237

lilacinus ........................................ 240

Marianus ....................................... 243

maritimus ..................................... 238

Mohavensis ........................241, 242

neglectus ......................................... 240

occidentalis ......................239, 10, 240

var. candidissimus ................... 240

var. Coulteri ......................239, 240

ochrocentrus .................................. 242

venustus ........................................ 239

Carphephorus junceus ..................... 125

Centaurea ............................................. 243

Cyanus ............................................. 244

Melitensis ......................................... 244

solstitialis ........................................ 244

Centromadia Fitchii ....................... 155

pungens .......................................... 154

var. Parryi .................................. 155

Chaenactis ...................................... 188

artemisiaefolia .............................. 199

attenuata ......................................... 193

brachypappa ................................. 194

carphoclinia ............................192, 11

var. attenuata ......................... 193

filifolia ............................................ 191

Fremonti .............................195, 196

glabriuscula ...........................189, 192

var. heterocarpha ............190, 191

f. curta .............................. 190

var. lanosa ............................... 192

var. Orcuttiana ........................ 192

var. tenuifolia ...................191, 192

f. filifolia ............................. 191

heterocarpha .................................. 190

var. curta .................................. 190

lacera ............................................. 199

lanosa ............................................. 192

macrantha ...................................... 197

Orcuttiana ....................................... 192

Parishii ..................................198, 199

santolinoides ................................... 197

stevioides ...............................193, 194

var. brachypappa ..............194, 191 


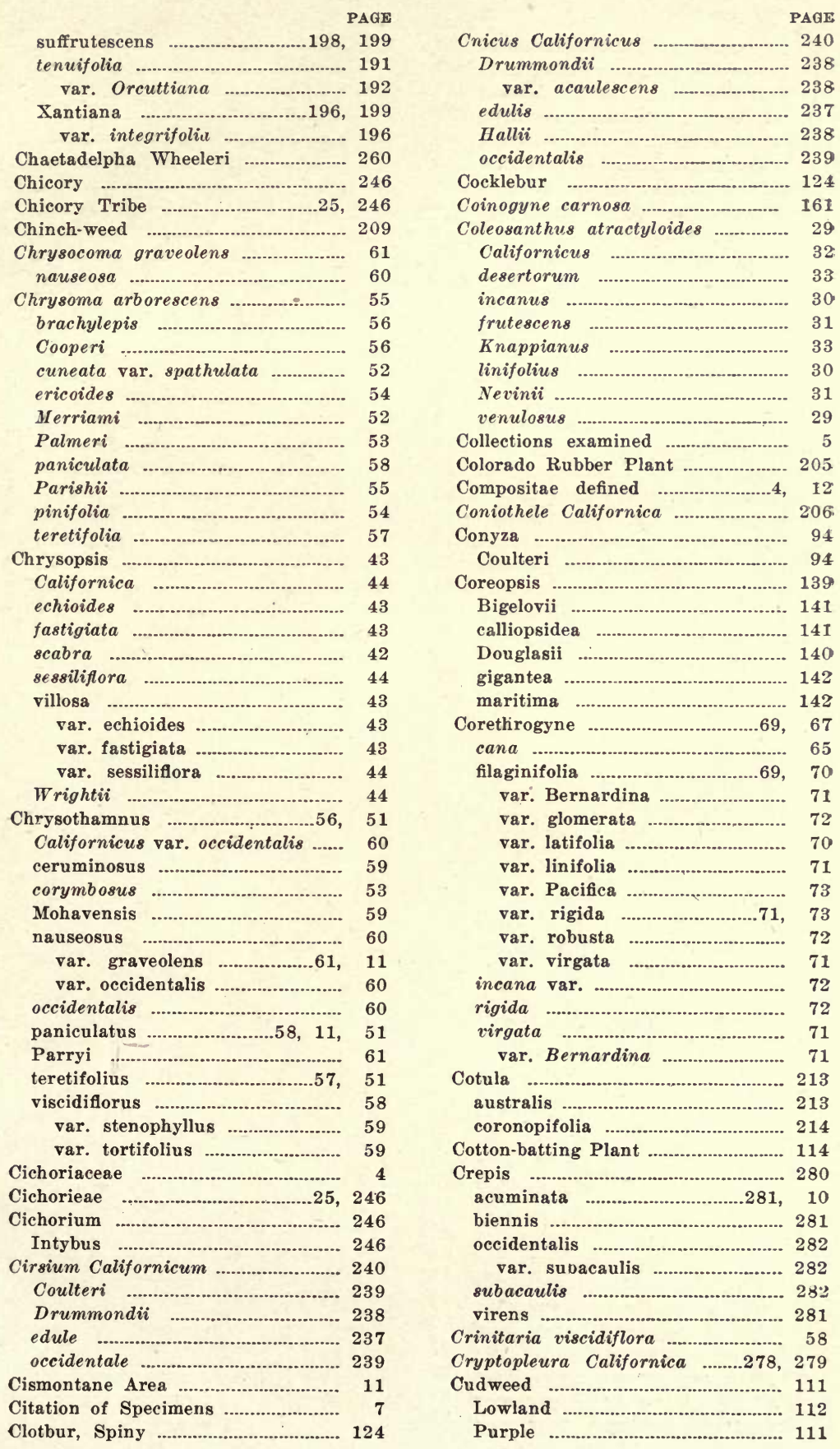




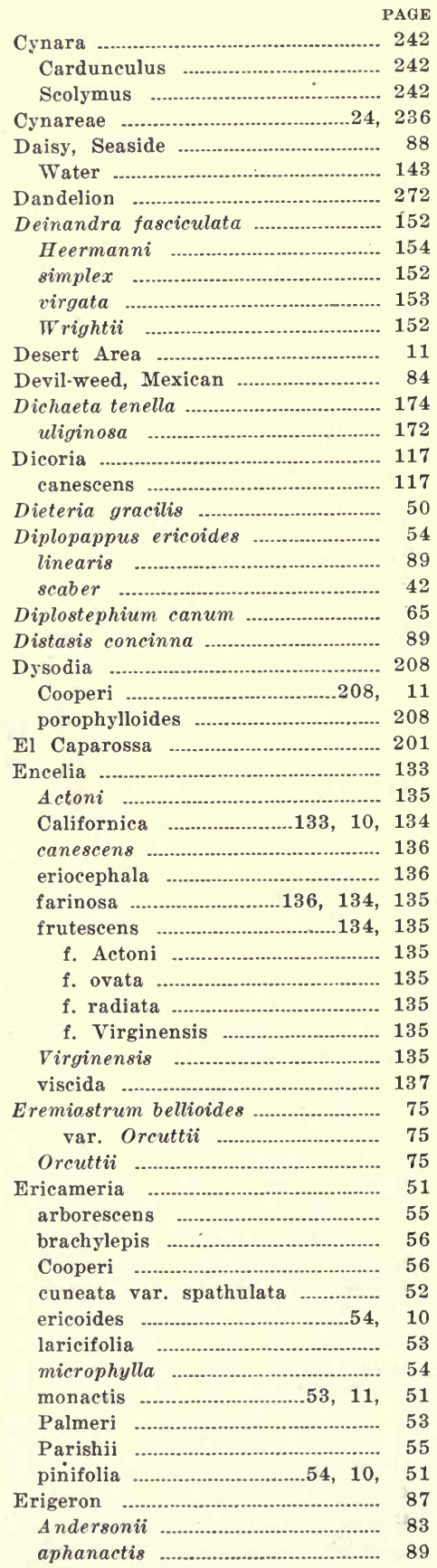

Blochmanae 91

Breweri .......................................... 90

camphoratus ................................. 101

Canadensis ..................................... 93

compositus ...................................... 90

var. discoideus ....................90, 9

concinnus ..................................... 89

var. aphanactis ....................... 89

divergens .................................... 92

filifolius .......................................... 89

foliosus ......................................91, 89

var. Blochmanae ..................... 91

var. stenophyllus ..................... 91

var. tenuissimus ........................ 91

fragilis ......................................... 91

glaucus ............................................ 88

incomptus ..................................... 92

Jacinteus ........................................ 86

linearis .......................................... 89

linifolius ......................................... 93

Nuttallii ...................................... 91

Parishii ....................................... 88

Philadelphicus ................................ 92

sanctarum ..................................... 90

stenophyllus .................................. 91

striatus ........................................... 92

tenuissimus ..................................... 91

Eriocarpum gracile ......................... 50

junceum …................................ 50

Eriophyllum …..................................... 180

ambiguum .............................182, 183

caespitosum ….............................. 187

confertiflorum …............................. 185

var. discoideum ........................ 186

var. latum ................................ 186

var. laxiflorum ........................... 186

var. trifidum ............................... 185

Heermanni .................................. 184

lanatum ........................................... 187

var. obovatum .....................186, 10

lanosum …....................................... 181

multicaule ….................................... 180

Nevinii ....................................185, 10

obovatum ..................................... 186

paleaceum .............................182, 183

Pringlei ….................................... 181

staechadifolium ............................ 184

Wallacei ….................................... 182

Eupatorieae ...................................14, 27

Eupatorium glandulosum ................ 34

Pasadenense .................................. 34

saggittatum ….................................. 34 .

Eupatory Tribe ............................14, 27

Euthamia occidentalis ................... 47

Evax .................................................... 106

caulescens var. sparsifiora .......... 106

multicaulis ...................................... 106

sparsiflora ........................................ 106 


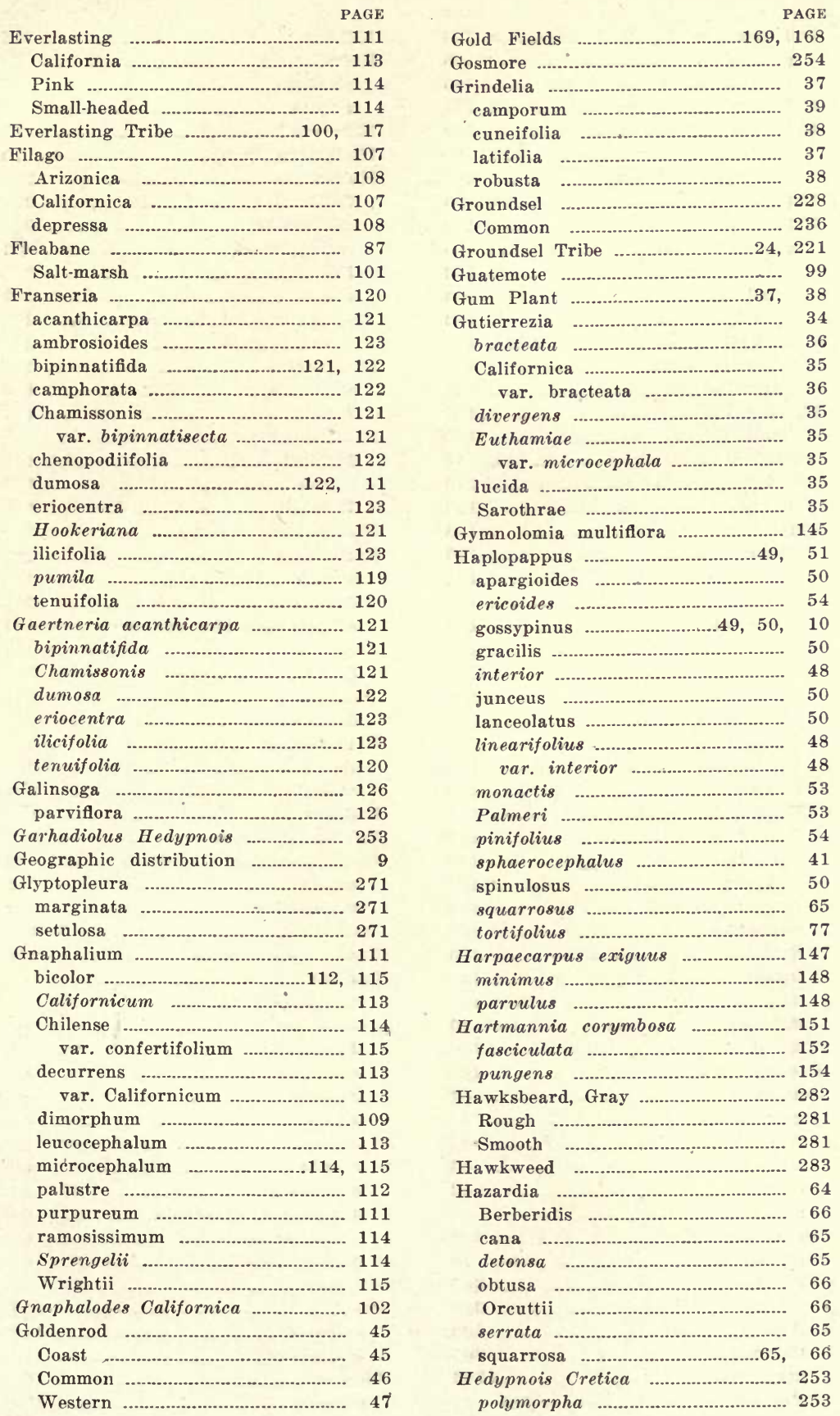




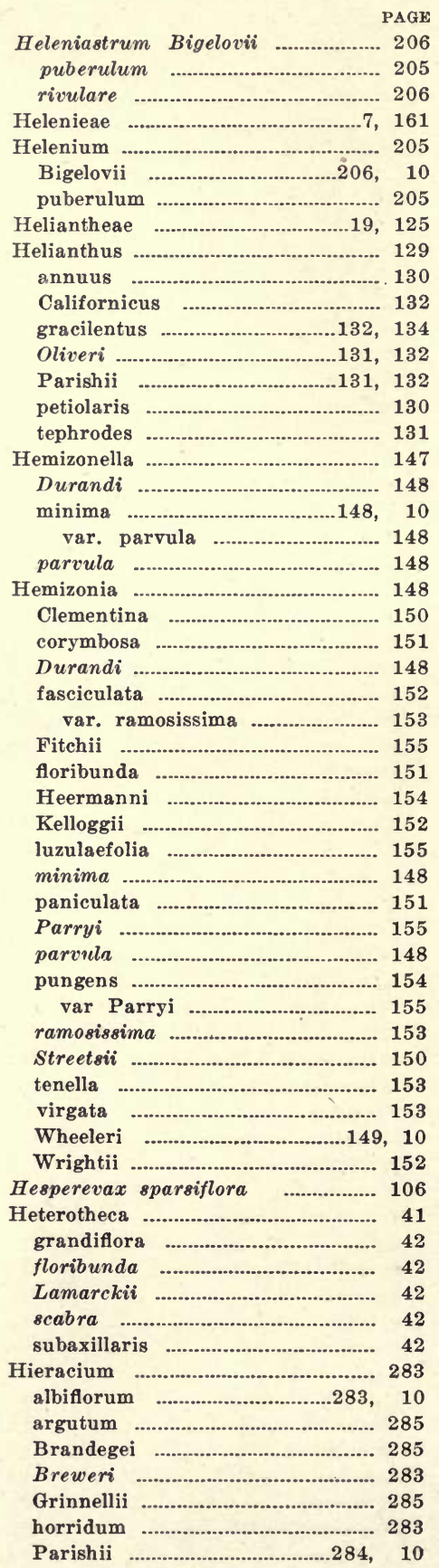

Hill-brush ......................................... 216

Hofmeisteria ......................................... 27

pluriseta ......................................... 27

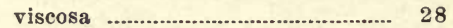

Horseweed ......................................... 93

Hudsonian Zone ..............................9, 10

Hulsea ................................................ 200

Californica …................................. 200

callicarpha ................................. 201

heterochroma ................................. 202

Parryi ........................................ 200

vestita ........................................... 200

var. eallicarpha ......................... 201

var. pygmaea ............................. 201

Hymenoclea ......................................... 118

monogyra ...................................... 118

Salsola .......................................... 118

Hymenopappus .................................. 177

filifolius …......................................... 178

lugens ............................................ 178

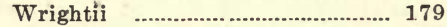

Hymenothrix Wrightii ...................... 179

Hymenoxys ......................................... 203

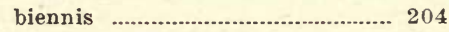

canescens var. biennis .................. 204

chrysanthemoides var. excurrens 204

Cooperi ............................................. 203

floribunda var. utilis ..................... 205

latissima .......................................... 204

Richardsonii .................................. 205

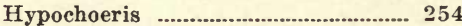

glabra ................................................. 255

radicata ............................................ 254

Incienso ............................................ 136

Infantea Chilensis .............................. 187

Inula ericoides ................................ 86

scabra ............................................. 42

subaxillaris ...................................... 42

Inuleae .............................................17, 100

Inyonia dysodioides ....................... 224

Isocoma n............................................ 62

acradenia ........................................ 64

bracteosa ....................................... 64

decumbens ................................62, 63

eremophila ....................................... 64

latifolia ..................................62, 63

leucanthemifolia ............................ 64

microdonta ................................62, 63

oxyphylla ................................... 64

sedoides ......................................62, 63

veneta var. acradenia.................... 64

var. vernonioides ...................... 62

vernonioides .............................62, 63 villosn ........................................62, 63

Iva ....................................................... 116

axillaris ........................................ 116

Hayesiana ...................................... 116

Jaumea ................................................. 161

carnosa ............................................ 161 


\begin{tabular}{|c|c|c|c|}
\hline & PAGE & & AGI \\
\hline Key to the genera ... & 14 & Life areas. & 11 \\
\hline ey to the tribes & 13 & 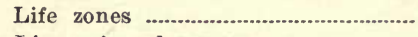 & \\
\hline ymapleura heterophylla ................. & 278 & Linosyris arborescens & \\
\hline actuca & 274 & 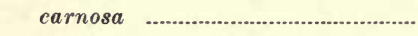 & \\
\hline Ludoviciana & 274 & ceruminosa & \\
\hline sativa & 274 & Parryi & \\
\hline Scariola & 274 & squamata & \\
\hline var. integrata & 274 & var. Breweri & \\
\hline 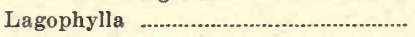 & 155 & teretifolia ............ & \\
\hline ramosissima & 156 & Lizard Tail & 18 \\
\hline peninsularis ....... & 166 & Lower Sonoran Zone ......... & \\
\hline Lasthenia ..................... & 167 & 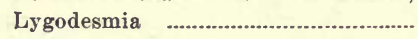 & 27 \\
\hline 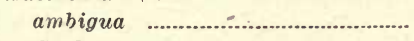 & 182 & exigua ......... & 27 \\
\hline Coulteri & 167 & $\operatorname{minor}$ & 25 \\
\hline glabrata & 167 & spinosa & -275 \\
\hline var. Coulteri ....... & 167 & Machaeranthera Pinosa ..............85, & \\
\hline ayia & 156 & 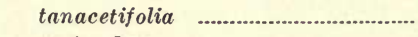 & \\
\hline 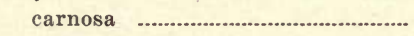 & 158 & tephrodes ... & 0 \\
\hline 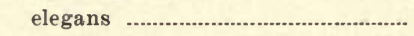 & 158 & Macrorhynchus angustifolius. & .27 \\
\hline glandulosa $\ldots \ldots \ldots .157,158,159$, & 182 & Chilense ........... & 27 \\
\hline var. heterotricha ...... & 158 & heterophyllus. & 278 \\
\hline var. rosea ................ & 157 & retrorsus ....... & 27 \\
\hline graveolens . & 159 & Madaria corymbosa var. hispida .... & 147 \\
\hline heterotricha & 157 & elegans & 14 \\
\hline hieracioides & 159 & Madaroglossa elegans ..... & 15 \\
\hline hispiaa ......... & 158 & heterotricha ................ & 15 \\
\hline Jonesii & 160 & hieracioides & 15 \\
\hline platyglossa & 160 & Madia ............... & 145 \\
\hline var. breviseta & 160 & dissitiflora & 146 \\
\hline Leontodon lividus & 272 & elegans $\quad .$. & 146 \\
\hline Taraxacum & 272 & var. hi & 147 \\
\hline Lepidospartum ........ & 221 & exigua & 147 \\
\hline squamatum & 11 & filipes & 147 \\
\hline Leptilon Canadense & 93 & lispida & 147 \\
\hline Leptoseris sonchoides .... & 264 & sativa & 146 \\
\hline Leptosyne Bi & 141 & tenella .............. & 150 \\
\hline Californica & 140 & Madia, Common & 146 \\
\hline callior & 141 & 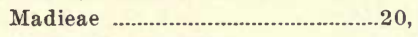 & 145 \\
\hline Douglasii .... & 140 & Madorella dissitiflora & 146 \\
\hline gigantea ...... & 142 & Malacolepis Coulteri & 263 \\
\hline insularis & 139 & Malacomeris incanus ........ & 267 \\
\hline maritima & 142 & Malacothrix ................... & 262 \\
\hline Mexicana ................... & 139 & altissima & 269 \\
\hline Newberryi & 140 & Californica & 264 \\
\hline pinnata .... & 139 & glabrata.. & 264 \\
\hline Lessingia & 66 & Clevelandi ........... & 266 \\
\hline albiflora ......................... & 69 & Coulteri & 263 \\
\hline Germanorum & 68 & Fendleri ... & 265 \\
\hline glandulifera ............................... & 69 & foliosa & 267 \\
\hline heterochroma & 67 & 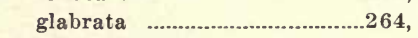 & 11 \\
\hline Lemmoni & 68 & implicata & 269 \\
\hline 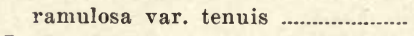 & 68 & (n)............ & 267 \\
\hline Lettuce & 274 & indecora & 267 \\
\hline Prickly & 274 & obtusa & 266 \\
\hline Leucelene & 86 & parvifiora ................................. & 266 \\
\hline des .. & 86 & platyphylla ... & 247 \\
\hline Leucosyris carnosa & 84 & saxatilis & 10 \\
\hline saxatilis & 268 & var. implicata & 269 \\
\hline 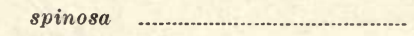 & 84 & var. tenuifolia & 268 \\
\hline ath & & 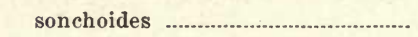 & 26 \\
\hline
\end{tabular}




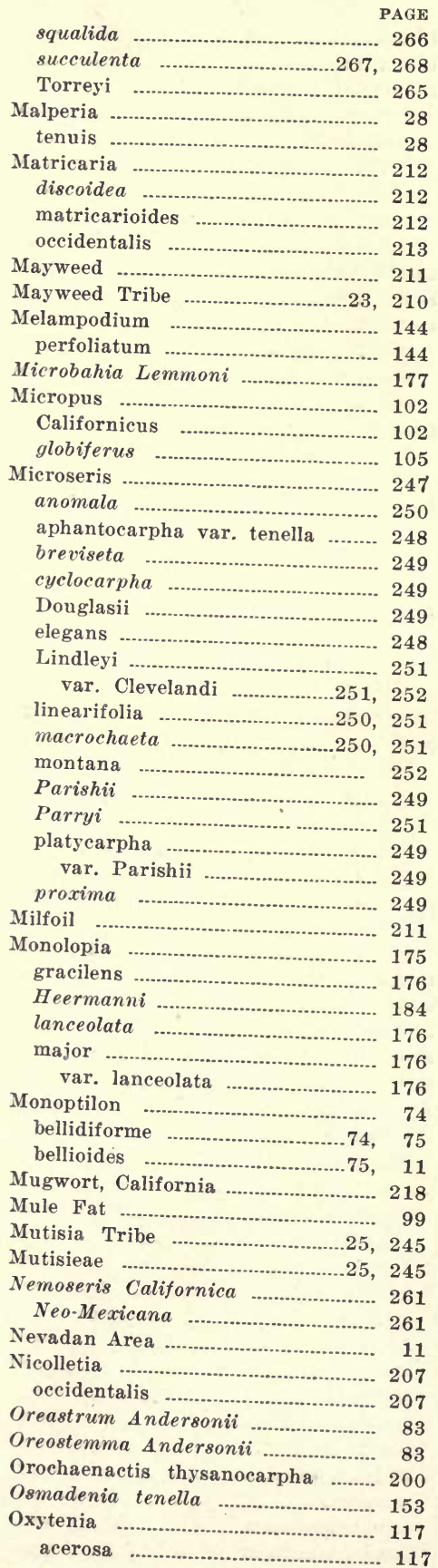

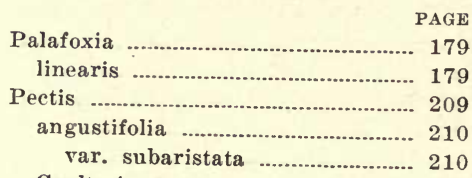

Coulteri .............................................. 210

filipes ........................................... 210

linifolia ........................................... 210

var. marginalis .......................... 210

papposa ................................209, 11

punctata ....................................... 210

Pentachaeta ....................................... 39

aurea ............................................ 39

Lyoni ................................................ 40

Oreuttii ........................................... 40

paleacea .................................................. 40

Perezia ................................................ 245

microcephala ..........................245, 10

Perityle ............................................. 164

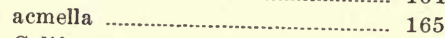

Californica ….............................. 166

Emoryi ......................................... 165

var nuda .................................... 166

var. Oreuttii ................................ 166

Fitchii ........................................... 166

Greenei ......................................... 166

leptoglossa ...................................... 166

microglossa .................................... 165

nuda ................................................ 166

plumigera ….................................. 166

rotundifolia .................................... 166

Peucephyllum …......................................... 223

Schottii ..................................224, 11

Picrothamnus desertorum ................ 215

Pluchea …....................................... 100

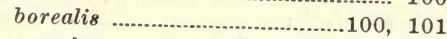

camphorata .........................101, 100

sericea ........................................... 101

Polypappus sericeus .............................. 101

Porophyllum .......................................... 209

gracile .....................................209, 11

Poverty Weed ......................................... 116

Prenanthes exigua ............................... 275

tenuifolia ........................................ 256

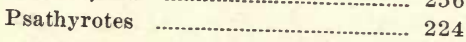

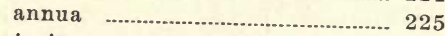

incisa .............................................. 202

ramosissima ................................... 225

Schottii ........................................... 224

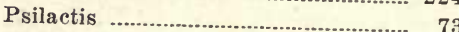

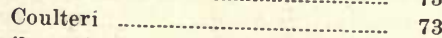

Psilocarphus ......................................... 104

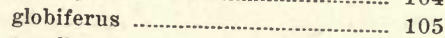

tenellus .......................................... 105

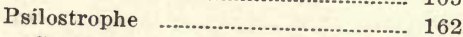

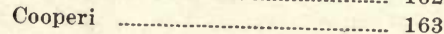

Pterostephanus runcinatus .............. 253

Ptilomeris affinis ............................... 174

anthemoides ........................................ 174 


\begin{tabular}{|c|c|c|c|}
\hline & PAGE & & PAGE \\
\hline 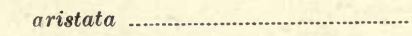 & 173 & triangularis ......... & 230 \\
\hline coronaria & 173 & trigonophyllus & 230 \\
\hline mutica ... & 173 & vulgaris & 235 \\
\hline tenella & 174 & 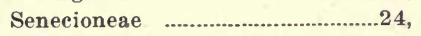 & 221 \\
\hline tiloria cichoriacea & 256 & Sericocarpus tortifolius ........................ & 77 \\
\hline divaricata .................. & 257 & 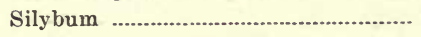 & 242 \\
\hline exigua ........ & 259 & Marianum & 243 \\
\hline Parryi & 256 & Simsia canescens & 136 \\
\hline pauciflora ... & 257 & frutescens ......... & 134 \\
\hline pentachaeta & 260 & Skevish ........ & 92 \\
\hline pleurocarpa & 258 & Snake's Head & 263 \\
\hline tenuifolia .. & 256 & Sneer & 205 \\
\hline tomentosa & 259 & & 206 \\
\hline virgata .... & 258 & Sneezeweed Tribe ...... & 161 \\
\hline Pugiopappus Bigelovii & 141 & Solidago ........................... & 45 \\
\hline 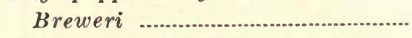 & 141 & Californica & 46 \\
\hline Pyrrocoma gossypina ........................... & 49 & 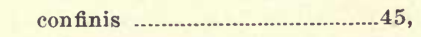 & 46 \\
\hline Rabbit-brush & 61 & xurians & 46 \\
\hline 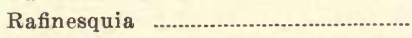 & 261 & limon & 45 \\
\hline 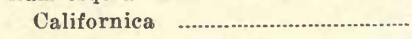 & 261 & $(-1)$ & 47 \\
\hline $\mathrm{Neo}-$ & 261 & & 35 \\
\hline agweed ................ & 119 & spathulata & 45 \\
\hline ern .................. & 119 & Soliva .............. & 214 \\
\hline Zagweed Tribe ............................ & 116 & sessilis & 214 \\
\hline 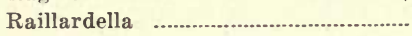 & 221 & Sone & 272 \\
\hline ......................... & 9 & & 273 \\
\hline Raillardia argentea & 221 & oleraceus & 273 \\
\hline Rhag & 252 & $a s_{1}$ & 273 \\
\hline $\mathrm{He}$ & 253 & tene & 273 \\
\hline 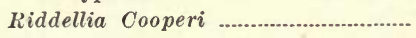 & 163 & Sow & 272 \\
\hline ppus ................................... & 187 & $\mathrm{Co}$ & 273 \\
\hline leptocladus & 188 & & 273 \\
\hline Rosilla ......................... & 205 & ed, Common & 154 \\
\hline 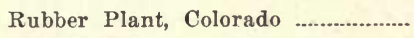 & 205 & 's ........................... & 155 \\
\hline Sagebrush & 219 & Stenotus ................... & - 48 \\
\hline Salsify $\quad \ldots .$. & 262 & linearifolius ............ & 49 \\
\hline 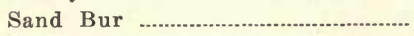 & 122 & & 48 \\
\hline 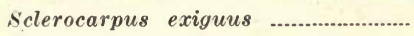 & 147 & Step & 255 \\
\hline 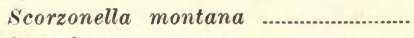 & 252 & ea & 256 \\
\hline io & 228 & naria & 259 \\
\hline 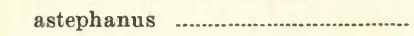 & 229 & (n) & 260 \\
\hline 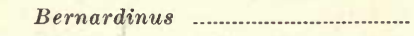 & -232 & exigua .. & 260 \\
\hline 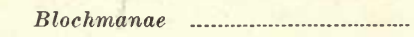 & 233 & var. $p$ & 260 \\
\hline Bre & 233 & lloger & 257 \\
\hline nicus. & 235 & & 256 \\
\hline Douglasii & 234 & lada & 258 \\
\hline ephalus & 233 & ....... & 256 \\
\hline (1)........................ & 229 & & 260 \\
\hline ionophyllus & 232 & ..........257, & 258 \\
\hline rnarainus ........................ & 232 & ii .......... & 260 \\
\hline var. sparsilobatus . & 232 & lia $\quad . . . . .$. & 256 \\
\hline (n) & 234 & osa & 259 \\
\hline (n) & 235 & & 258 \\
\hline Monoensis & 234 & var. pleurocarpa & 258 \\
\hline Parryi & 236 & Stylocline & 102 \\
\hline serra var. integriuscula ................. & 230 & .................... & 104 \\
\hline var. sanctus & 230 & gnaphalioides ................... 103, 104, & 105 \\
\hline sparsuovat & 232 & micropoides ........ & 103 \\
\hline sylvaticus & 235 & Stylopappus elatus & 279 \\
\hline
\end{tabular}




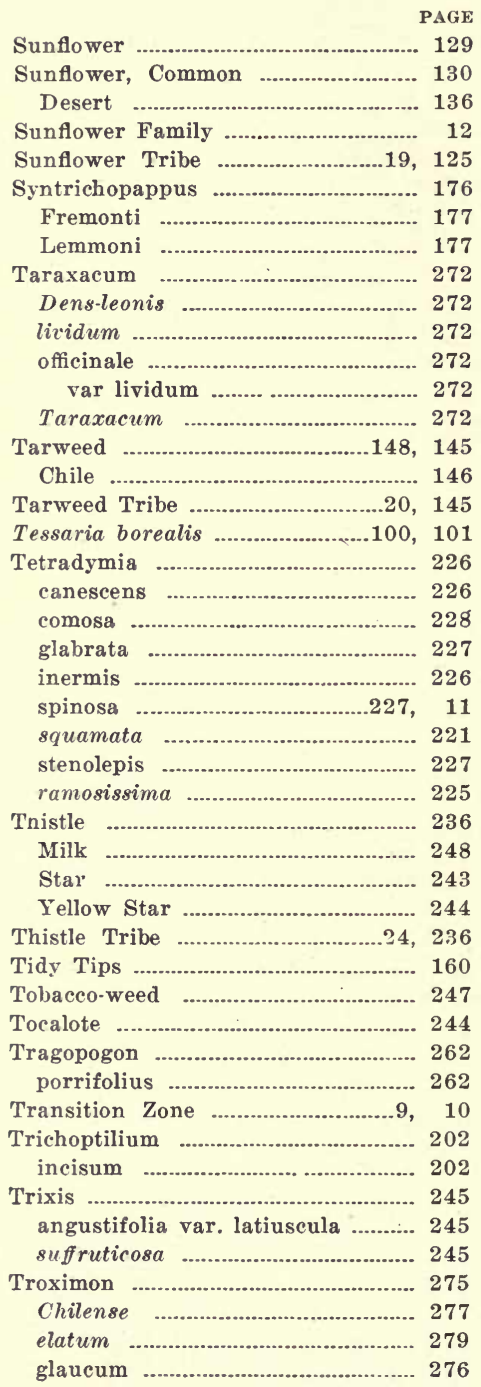

PAGE

277,278

var. Californicum ...........278, 280
f. crenulatum .............279, 280

f. idiale .........................278, 279

f. turgidum ......................279, 280

f. cryptopleurum ...................... 278

f. kymapleurum ......................... 278

f. normale (.............................. 277

plebeium ....................................... 276

retrorsum ........................................ 276

Tuckermannia maritima .................. 142

Tumionella monactis .......................... 53

Upper Sonoran Zone ....................9, 10

Uropappus Clevelandi ...................... 251

Lindleyi .......................................... 251

var. Clevelandi ......................... 251

linearifolius _.................................... 250

Vegetable Oyster .............................. 262

Venegasia ........................................ 162

carpesioides $\quad$............................... 162

Verbesina ........................................ 137

australis ............................................ 138

dissita ........................................... 137

encelioides ...................................... 138

var. exauriculata ..................... 138

microptera ..................................... 138

Viguiera ................................................ 128

deltoidea var. Parishii ................... 129

laciniata ........................................ 128

Parishii ....................................... 129

reticulata ….................................... 129

Wormwood ............................................. 215

Wyethia ............................................... 127

coriacea .......................................... 127

ovata .............................................. 127

Xanthium …...................................... 123

Canadense ...................................... 124

orientale ........................................ 124

spinosum ........................................ 124

Xanthocephalum lucidum ............... 35

Ximenesia australis ........................ 138

microptera .................................... 138

Xylorhiza Orcuttii ............................ 78

tortifolia ......................................... 77

Yarrow, Common ................................ 211

Zonanthemis corymbosa .................. 151

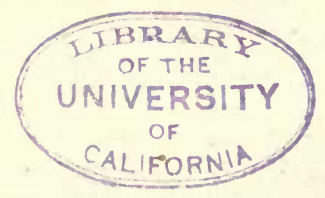




\section{ADDENDUM.}

Artemisia Rothrockii Gray, Bot. Calif. i. 618 (1876).

A low shrub, nearest to $A$. tridentata: herbage canescent with a close pubescence: leaves 1 to $2 \mathrm{~cm}$. long, sometimes narrowly cuneate and obtusely 3 -lobed at summit, usually spatulate-lanceolate or linear and entire, obtuse: heads glomerate-paniculate, 12 to 14-flowered: involucre larger than in A. tridentata and more globose, about $4 \mathrm{~mm}$. high; bracts ovate or oval.

San Bernardino Mts., at 2100 m. alt., with A. tridentata, Aug. 25, 1907, Vernon Bailey: eastern crest of the Sierra Nevadas from Olancha Peak to Mt. Dana. 


\section{PLATE 1.}

Aster Menziesii Lindl.

1 and 2. Flowering stems, showing the rigid leaves with broad sessile base and the arrangement of the heads.

3. Leaf-surface, showing the character of the pubescence.

4. An outer bract of the involucre.

5. An inner bract of the involucre.

6. A ray-flower.

7. The style-branches of a ray-flower.

8. A disk-flower.

9. The style-branches of a disk-flower.

10. Three stamens from a disk-flower.

11. A single pappus-bristle from a disk-flower.

All the figures were drawn from the type specimen at Kew by Miss M. Smith under the direction of W. L. Jepson. 


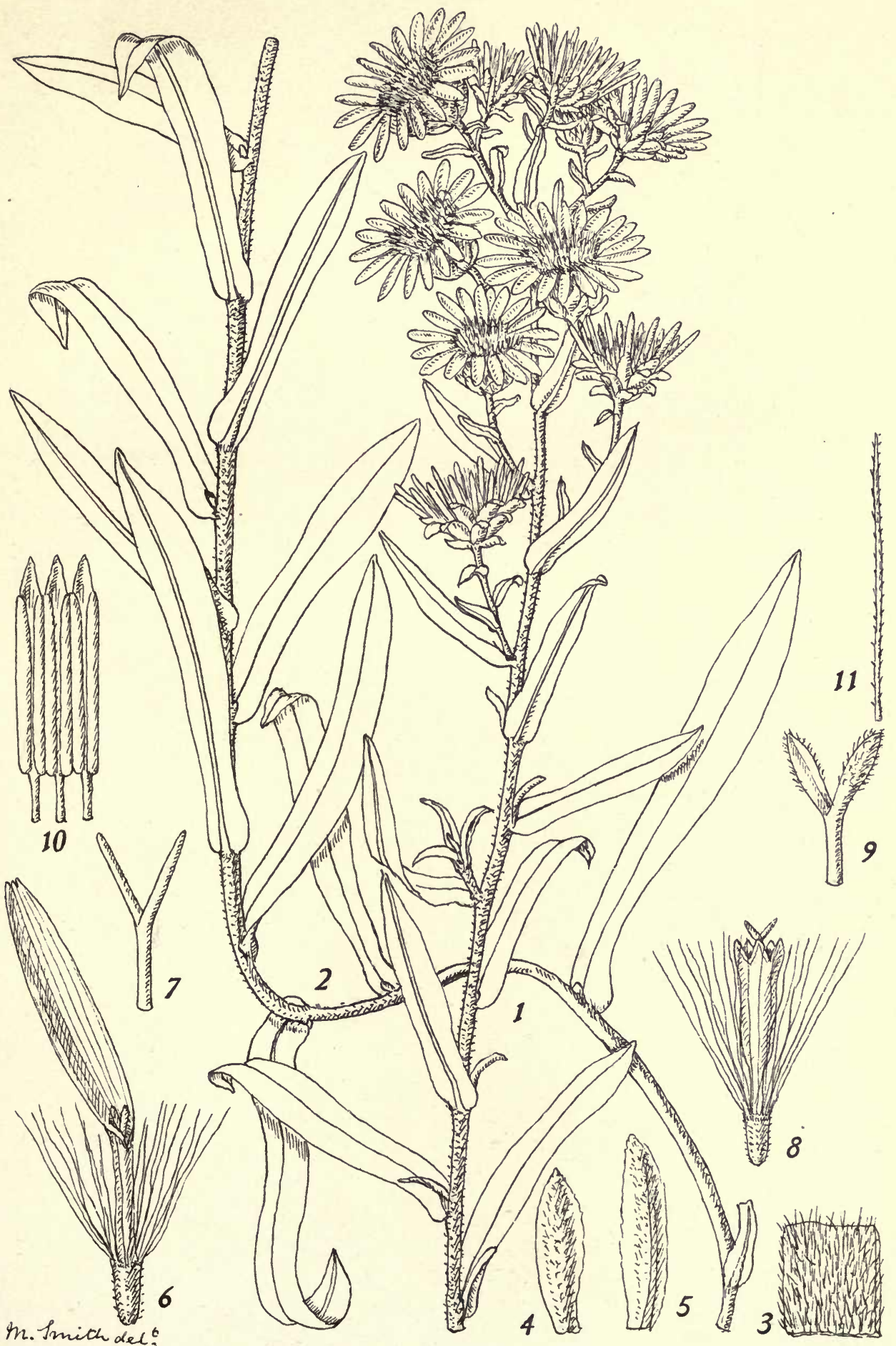




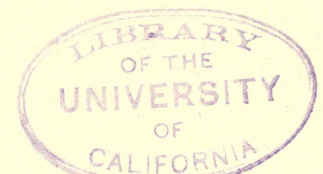





\section{PLATE 2.}

\section{Aster Bernardinus Hall.}

12. A flowering stem, showing the lax foliage and the arrangement of the heads.

13. A more loose inflorescence.

14. Leaf-surface, showing the character of the pubescence.

15. Two leaf-hairs.

16. An outer bract of the involuere.

17. An inner bract of the involucre.

18. A ray-flower.

19. The style-branches of a ray-flower.

20. A disk-flower.

21. The style-branches of a disk-flower.

22. Three stamens from a disk-flower.

23. A single pappus-bristle from a disk-flower.

Figures 12 and 13 are reduced to one-half. The remaining figures are enlarged.

All the figures were drawn by $\mathrm{H}$. N. Bagley under the direction of H. M. Hall. 


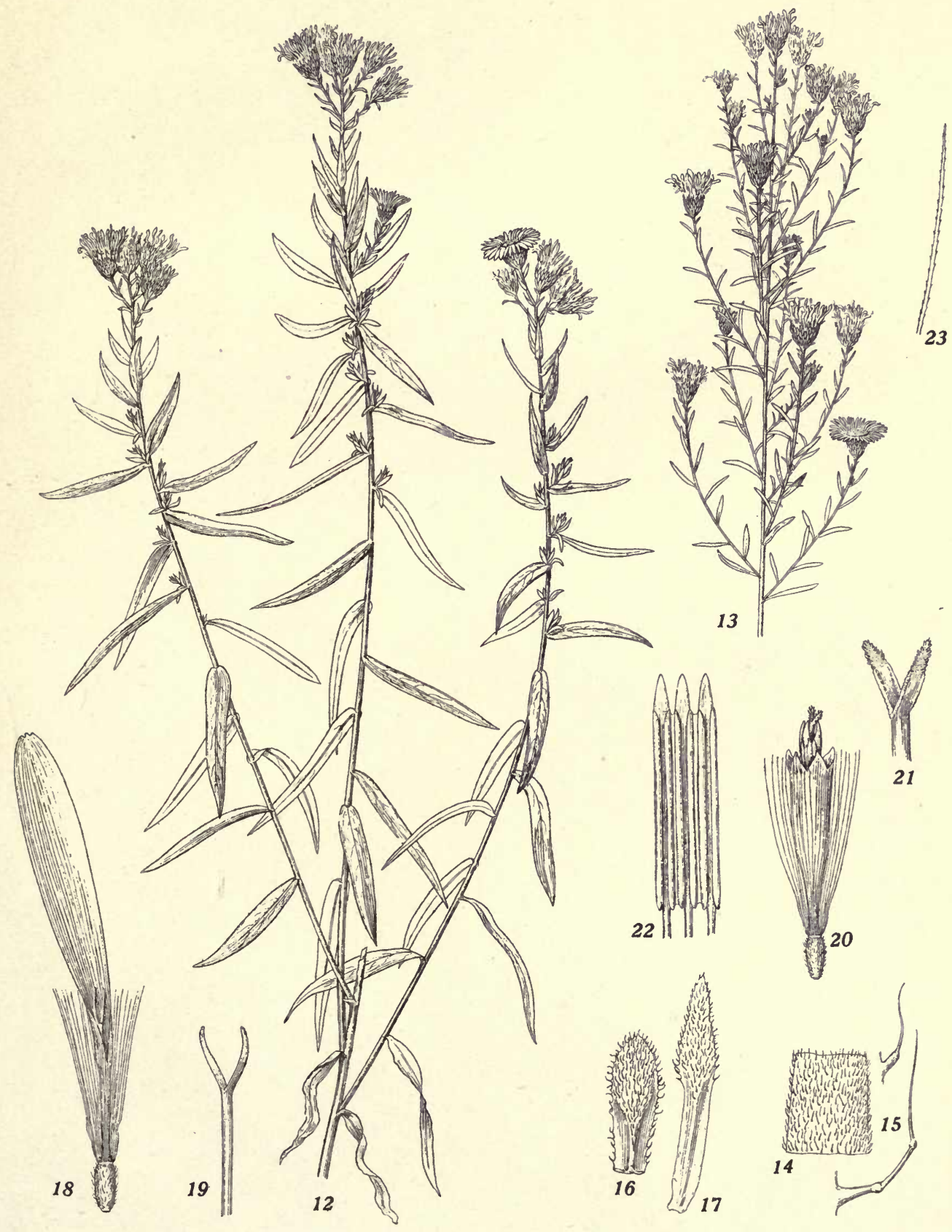






\section{PLATE 3.}

\section{Aster delectabilis Hall.}

24. An entire plant, showing the habit, the sheathing leaf-bases, and the solitary head.

25. An inflorescence of two heads, showing the arrangement of the bracts of the involucre.

26. A portion of a leaf, showing the margins and venation.

27. A portion of the upper part of the stem, showing the character of the pubescence.

28. An outer bract of the involucre.

29. An inner bract of the involucre.

30. A ray-flower.

31. The style-branches of a ray-flower.

32. A disk-flower.

33. The style-branches of a disk-flower.

34. Three stamens from a disk-flower.

35. A single pappus-bristle from a disk-flower.

Figures 24 and 25 are reduced to one-half. The remaining figures are enlarged.

All the figures were drawn by H. N. Bagley under the direction of H. M. Hall. 


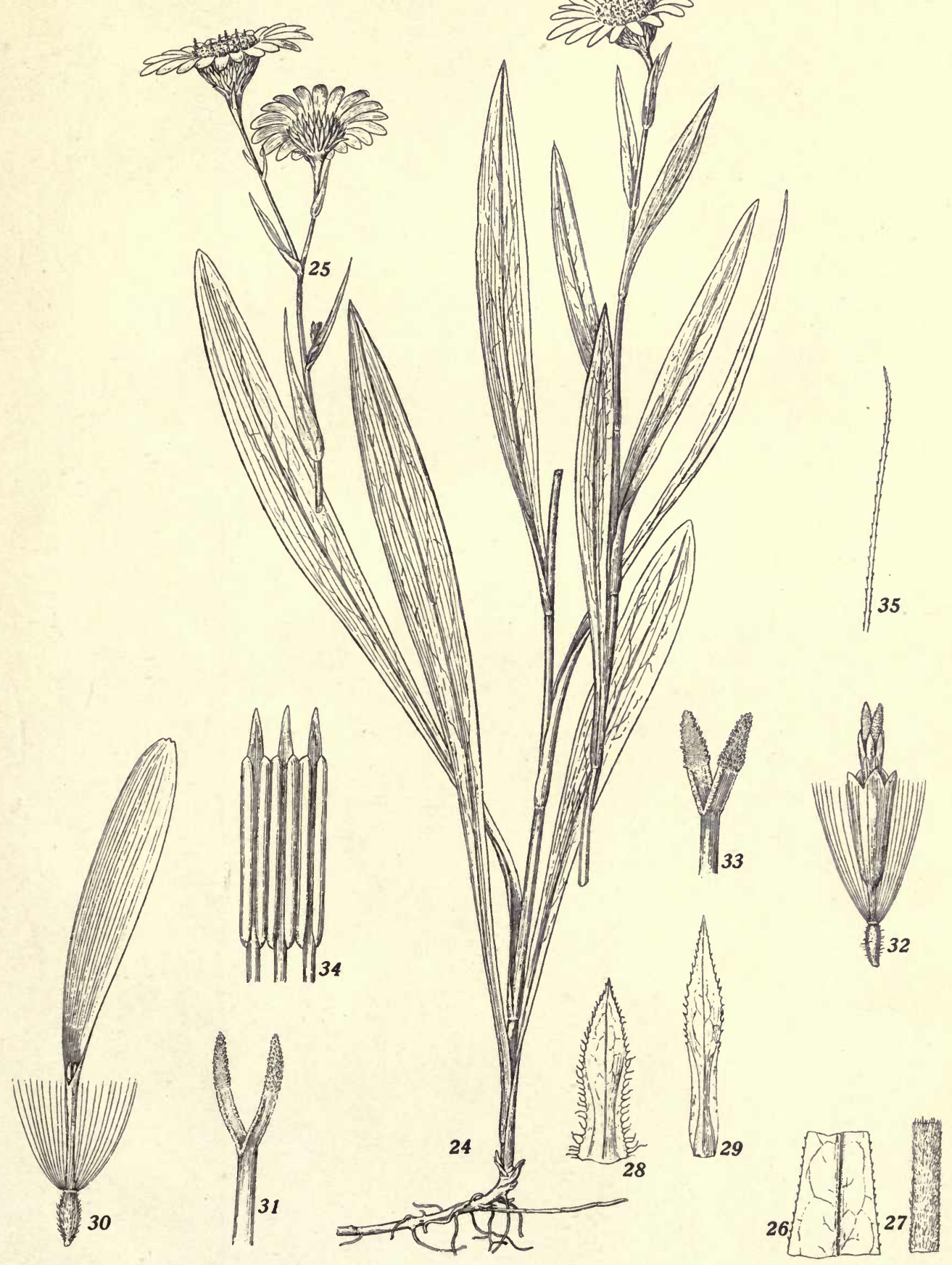


YTHLART
OF THE

UNIVERSITY

OF

CAL'FORNIA 


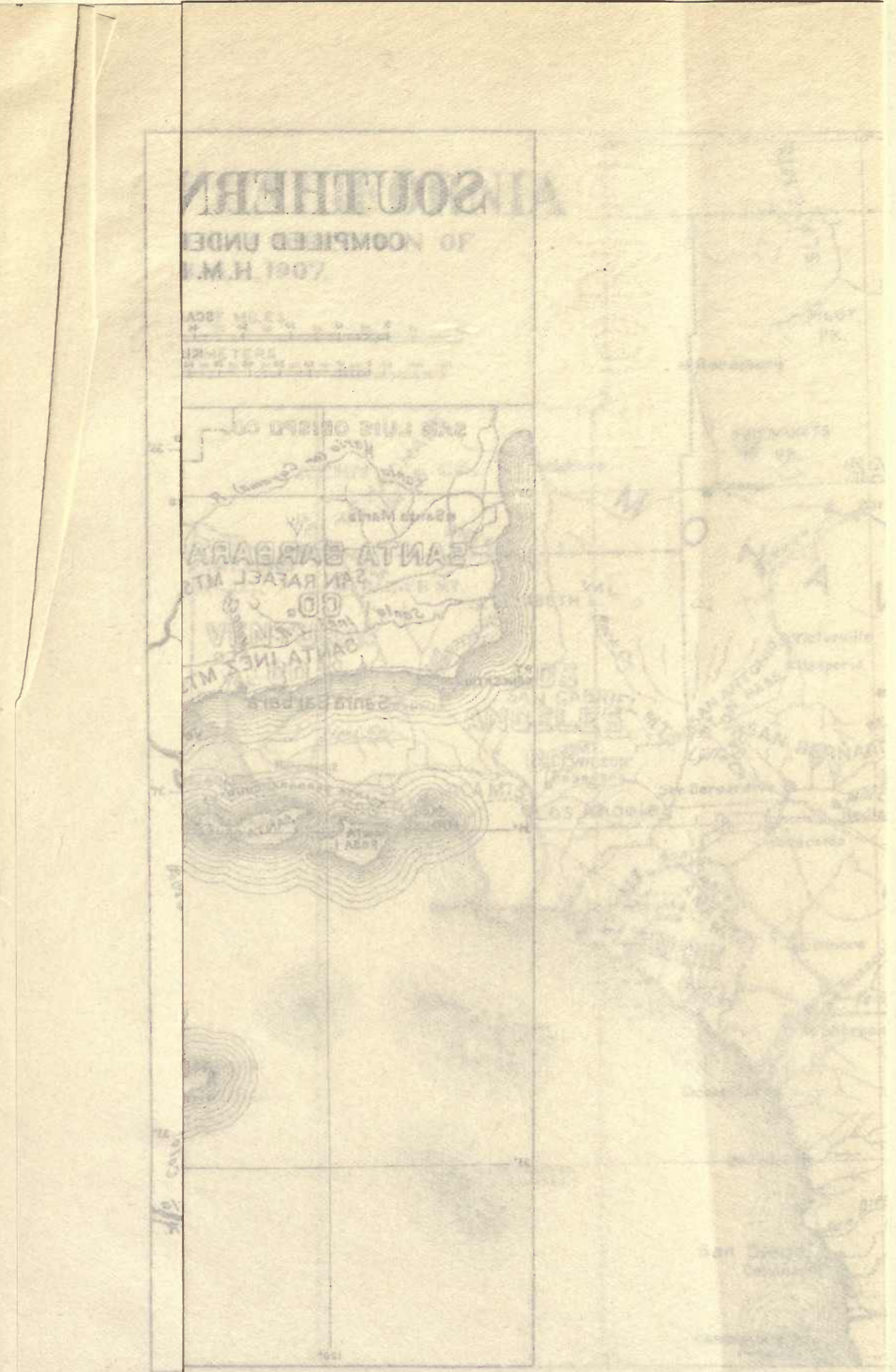




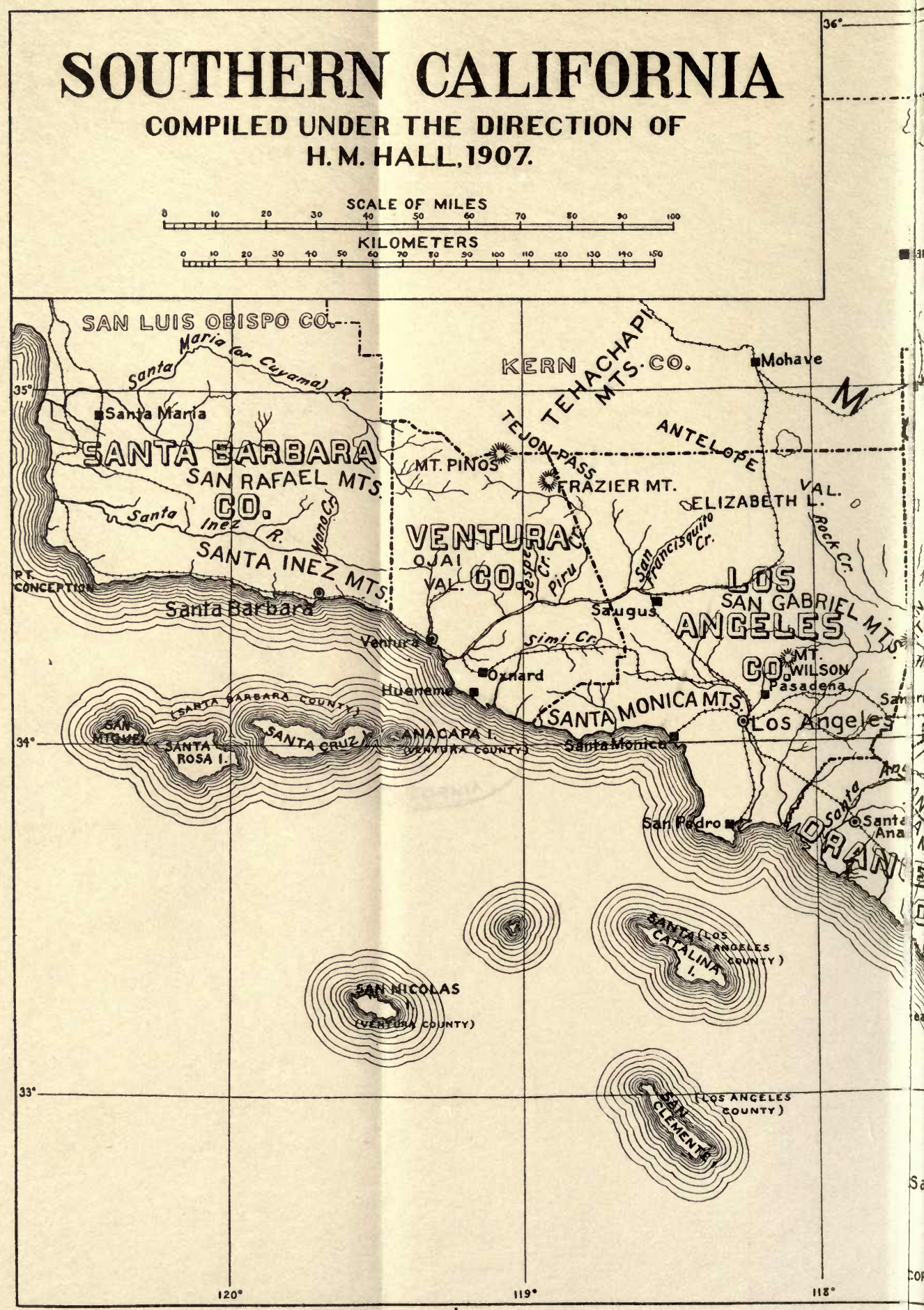




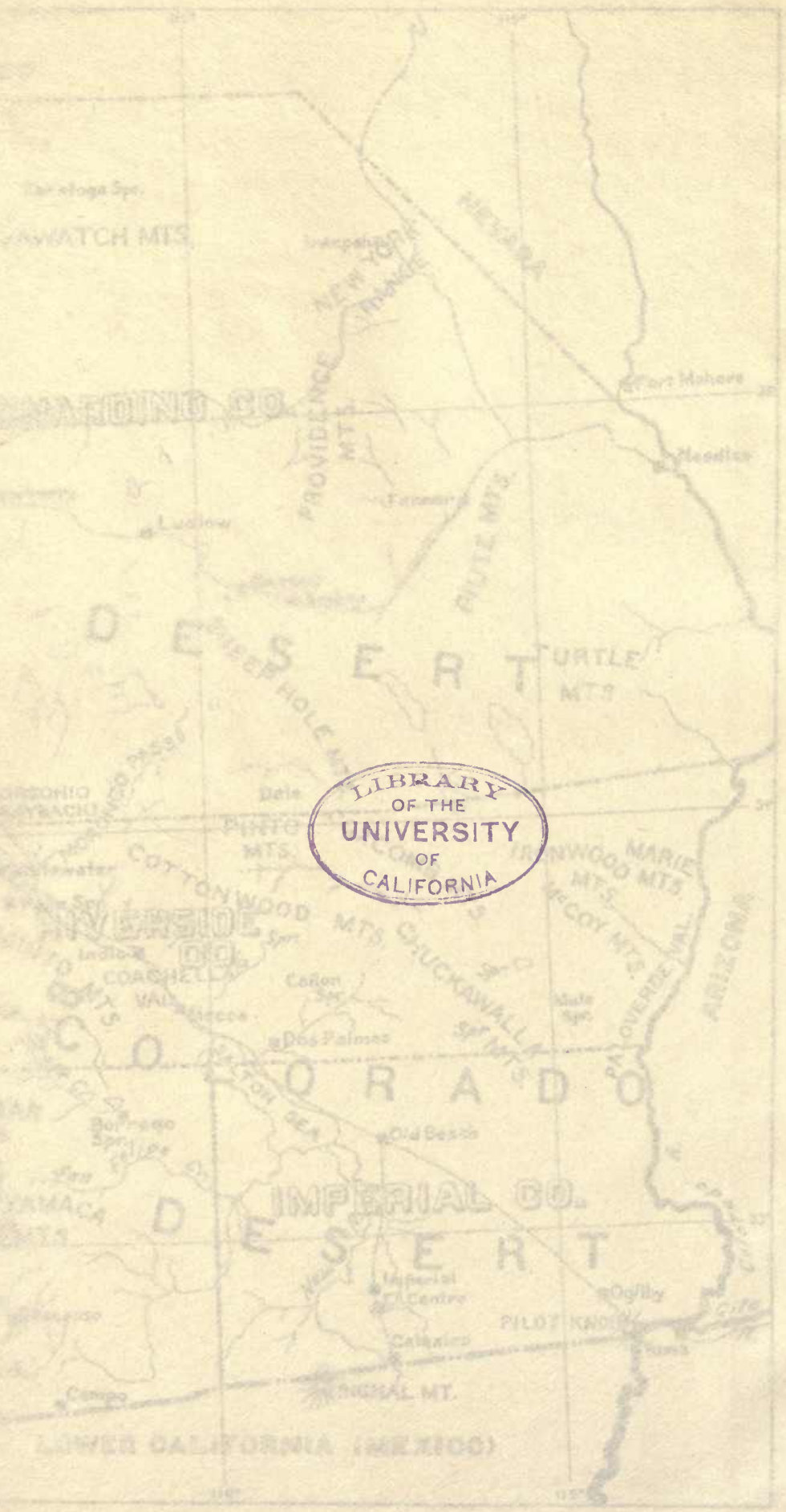




AMERICAN ARCHAEOLOGY AND ETHNOLOGY. (OctavO).

Vol. 1. 1903-1904. 378 pp., with 30 plates. . . Price, $\$ 4.25$

Vol. 2. 1904-1907. 392 pp, with 21 plates and map.: Price, 3.50

Vol. 3. The Morphology of the Hupa Language, by Pliny Earle Goddard. Pages 344, June, 1905. - . Price, 3.50

Vol. 4. 1906-1907. 356 pp., with 10 plates. P. Price, 3.50

Vol. 5. No. 1. The Phonology of the Hupa Language: Part I, The Ind1vidual Sounds, by Pliny Earle Goddard. Pages 20, Plates 8 , March, 1907. . Price,

No. 2. Navaho Myths, Prayers and Songs with Texts and Translations, by Washington Matthews, edited by Pliny Earle Goddard. Pages 43, September, $1907 . \quad$ Price,

Vol. 6. No. 1. The Ethno-Geography of the Pomo Indians, by S. A. Barrett (in press).

Vol. 7. No. 1. The Emeryville Shellmound, by Max Uhle. Pages 106, Plates 12, June, 1907 .

ASTRONOMY.-W. W. Campbell, Editor. (Lick Observatory, Mt. Hamilton, Cal.)

Publications of the Lick Observatory.-Volumes I-V completed. Volumes

Vo. 7:VII and IX in progress. Volume VIII in press.

No. 1. A Short Method of Determining Orbits from Three Observations, by $A .0$. Leuschner.

No. 2. Elements of Asteroid $1900 \mathrm{GA}$, by A. O. Leuschner and Adelaide M. Hobe.

No. 3. Preliminary Elements of Comet 1900 III, by R. H. Curtiss and

Vol. 9:C. G. Dall.

No. 1. Organization and History of the D. O. Mills Expedition to the Southern Hemisphere.

No. 2. Introductory Account of the D. O. Mills Expedition.

No. 3. Description of the Instruments and Methods of the D. O. Mills Expedition.

Lick Observatory Bulletins.-Volumes I-III completed. Volume IV (in progress).

CLAssicaI PHILOLOGY.-Edward B. Clapp, William A. Merrill, Herbert C. Nutting, Editors. Price per volume $\$ 2.00$. Volume I (in progress).

No. 1. Hiatus in Greek Melic Poetry, by Edward B. Clapp. Price, $\$ 0.50$

No. 2. Studies in the Si-clause, by Herbert C. Nutting. guage, by Benj. Ide Wheeler of .25

No.4. On the Influence of Lucretius on Horace, by William A.

$\begin{array}{llll}\text { No. 5. The Priests of Asklepios (A New Method of Dating Athenian } & .25 \\ \text { No. 6. Horace's Alcaic Strophe, by Leon Josiah Richardson } & \text { "6 } & .50 \\ \end{array}$

$\begin{array}{llr}\text { No. 5. The Priests of Asklepios (A New Method of Dating Athenian } & .25 \\ \text { No. 6. Horace's Alcaic Strophe, by Leon Josiah Richardson } & \text { "6 } & .50 \\ \text { Nons } & .25\end{array}$

No. 7. Some Phases of the Relation of Thought to Verse in Plautus, by Henry W. Prescott $\quad . \quad 0 \quad 00$

EDUCATION.-Edited by the Department of Education. Price per volume $\$ 2.50$.

Volume I (pp. 424). Notes on the Development of a Child, by Milicent $W$.

Vol. II (in progress).-No. i. Notes on Children's Drawings, by Elmer E.

Vol. III (in progress) - No. 1. Origin of American State Universities, by Elmer E. Brown . Price, No. 2. State Aid to Secondary Schools, by David

Vol. IV. Notes on the Development of a Child. II -The Development of the Senses in the First Three Years of Childhood, by Milicent Washburn Shinn (in press).

Vol. V (in progress).-No. 1. Superstition and Education, by Fletcher Bascom Dresslar. 
ENGINEERING.-Edited under the direction of the Engineering Departments. This series will contain contributions from the Colleges of Mechanics, Mining, and Civil Engineering. Volume I in progress.

No. 1. Bulletin of the Department of Civil Engineering. 1.-Moment Diagrams and Typical Live Loads, by Charles Derleth, Jr., Pages 1-9, Plate 1. January, 1907. . . . Price,

GEOLOGY.-Bulletin of the Department of Geology. Andrew C. Lawson, Editor. Price per volume $\$ 3.50$. Volumes I (pp. 428), II (pp. 450), III (475) and IV (462), completed. Volume V' (in progress).

9. Benitoite, a New California Gem Mineral, by George Davis Louderback, with Chemical Analysis by Walter C. Blasdale. Pp. 149-153, July, $1907 . \quad$. Price,

10. Notes on Quaternary Felidae from California, by John F. Bovard.

11. Tertiary Faunas of the John Day Region, by John C. 'Merriam and William J. Sinclair. Pp. 171-205, October, $1907 . \quad$ Price,

PATHOLOGY.-Alonzo Englebert Taylor, Editor. Price per volume, $\$ 2.50$. Volume I (PP. 347) completed.

Lectures on Fermentation, by Alonzo Englebert Taylor (Pathology, Volume 1, No. 8)

PHILOSOPHY.-Volume I, completed. Price, $\$ 2.00$.

PHYSIOLOGY.-Jacques Loeb, Editor. Price per volume \$2.00. Volume 1 (pp. 217) completed. Volume II (pp. 215) completed. Volume III (in progress).

No. 8. On the Production of a Fertilization Membrane in the Egg of the Sea-Urchin with the Blood of Certain Gephyrean Worms (a preliminary note), by Jacques Loeb.

No. 9. Note on the Synthesis of Protein through the Action of Pepsin, by T. Brailsford Robertson.

No. 10. The Chemical Character of the Process of Fertilization and its bearing on the theory of Life Phenomena, by Jacques Loeb.

John Bruce MacCallum: On the Mechanism of the Physiological Action of the Cathartics.

Z00LOGY.-W. E. Ritter, Editor. Price per volume $\$ 3.50$. Volumes I (pp. 317), II (pp. 382) and III (pp. 383) completed. Volume IV in progress. Commencing with Volume II, this series contains Contributions from the Laboratory of the Marine Biological Association of San Diego.

No. 1. The Ascidians Collected by the United States Fisheries Bureau Steamer Albatross on the Coast of California During the Summer of 1904 , by Wm. E. Ritter. Pp. 1-52, plates 1-3. Price,

No. 2. Behavior of the Starfish Asterias Forreri De Loriol, by H. S. Jennings. Pp. 53-185, 19 text-figures. . Price, 1.00

UNIVERSITY CHRONICLE.-An official record of University life, issued quarterly, edited by a committee of the faculty. Price, $\$ 1.00$ per year. Current volume No. $X$.

Address all orders, or requests for information concerning the above publications to The University Press, Berkeley, California.

European agent for the series in American Archaeology and Ethnology, Classical Philology, Education, Philosophy, and Semitic Philology, Otto Harrassowitz, Leipzig. For the series in Botany, Geology, Pathology, Physiology, Zoology and also American Archaeology and Ethnology, R. Friedlaender \& Sohn, Berlin. 






\section{NON-GIRCULATING BOOK}

U. C. BERKELEY LIBRA 
